\title{
J.A.A. van Doorn en de Nederlandse sociologie De erfenis, het debat en de toekomst
}

Onder redactie van Jacques van Hoof, Dick Houtman, Peter Mascini, René Moelker en Sjo Soeters 
J.A.A. van Doorn en de Nederlandse sociologie 



\title{
J.A.A. van Doorn en de Nederlandse sociologie
}

\author{
De erfenis, het debat en de toekomst
}

Onder redactie van

Jacques van Hoof

Dick Houtman

Peter Mascini

René Moelker

Sjo Soeters 
Omslagontwerp: Maedium, Utrecht

Vormgeving binnenwerk: ProGrafici, Goes

\author{
ISBN $\quad 9789085550136$ \\ e-ISBN 9789048511006 \\ NUR $\quad 741$
}

(C) Jacques van Hoof, Dick Houtman, Peter Mascini, René Moelker en Sjo Soeters / Pallas Publications - Amsterdam University Press, Amsterdam 2010

Alle rechten voorbehouden. Niets uit deze uitgave mag worden verveelvoudigd, opgeslagen in een geautomatiseerd gegevensbestand, of openbaar gemaakt, in enige vorm of op enige wijze, hetzij elektronisch, mechanisch, door fotokopieën, opnamen of enige andere manier, zonder voorafgaande schriftelijke toestemming van de uitgever.

Voor zover het maken van kopieën uit deze uitgave is toegestaan op grond van artikel 16B Auteurswet 1912 jo het Besluit van 20 juni 1974, Stb. 351, zoals gewijzigd bij het Besluit van 23 augustus 1985, Stb. 471 en artikel 17 Auteurswet 1912, dient men de daarvoor wettelijk verschuldigde vergoedingen te voldoen aan de Stichting Reprorecht (Postbus 3051, 2130 KB Hoofddorp). Voor het overnemen van gedeelte(n) uit deze uitgave in bloemlezingen, readers en andere compilatiewerken (artikel 16 Auteurswet 1912) dient men zich tot de uitgever te wenden. 


\section{Inhoudsopgave}

Woord vooraf 9

Jacques van Hoof, Dick Houtman, Peter Mascini, René Moelker en Sjo Soeters

DeEl I VAN DOORN EN DE NAOORLOGSE SOCIOLOGIE

1 In memoriam J.A.A. van Doorn

Cor Lammers

2 J.A.A. van Doorn als socioloog Continuïteit en discontinuïteit Joop Ellemers

DeEl II SOCIOLOOG OF HISTORICUS?

3 Van Doorns werk

Van verkeerd gesystematiseerde sociologie naar meer gedegen geschiedwetenschap?

Wout Ultee

4 Overzeese verkenningen op het grensvlak van geschiedenis en sociologie

Leonard Blussé

5 Relativering van rationaliteit

Naar een reflexieve beleidssociologie

Romke van der Veen

6 Een paar apart

Fortuyn en Van Doorn als publieke sociologen

Dick Pels 
7 Van Doorn in crisis

Over militaire transformatieprocessen

René Moelker

8 Sociologen en de krijgsmacht

Een gespannen verhouding

Casper W. Vroom

9 De fuik van militaire avonturen

Indië, Bosnië, Afghanistan

Jan van der Meulen

10 J.A.A. van Doorn en de moderne sociologie Het einde van een intellectuele traditie

Dick Houtman

Slotbeschouwing

Van Doorn en de toekomst van de sociologie

Jacques van Hoof, Dick Houtman, Peter Mascini, René Moelker en Sjo Soeters

Over de auteurs 


\section{Tabellen en figuren}

\section{Tabellen}

Tabel 1 Percentage stemmen voor de belangrijkste politieke partijen bij alle verkiezingen voor de Rijksdag in Duitsland van 1919 tot 1933

Tabel 2 Percentage kiezers voor een bepaalde partij bij een bepaalde verkiezing voor de Rijksdag in Duitsland dat bij de volgende verkiezing NSDAP stemde

Tabel 3 Ontwikkeling van de militaire en civiele arbeidsdeelname van vrouwen in de NAVO-landen

\section{Figuren}

Figuur 1 Vragen uit Van Doorns afzonderlijke studies verenigd tot cohesievragen

Figuur 2 Verdeling van de sociologische arbeid

Figuur 3 Publieke sociologie: kennis van/voor wie? $\quad 89$

Figuur 4 Illustraties van Jacob de Gheyn 106

Figuur 5 Dienstplicht-ratio's 



\section{Woord vooraf}

Jacques van Hoof, Dick Houtman, Peter Mascini, René Moelker en Sjo Soeters

Op 14 mei 2008 overleed Jacques van Doorn. Hoewel hij gedurende de laatste jaren van zijn leven op enige afstand van de sociologie was komen te staan, heeft hij als geen ander een stempel gedrukt op de ontwikkeling van de naoorlogse sociologie in Nederland. Sociologen die op heel verschillende terreinen werkzaam zijn, weten zich schatplichtig aan de ideeën die hij steeds met zoveel verve en eruditie heeft verdedigd.

Hij was ook erelid van de Nederlandse Sociologische Vereniging (NSV). Deze statuur van Van Doorn binnen de sociologische discipline als geheel en de vereniging in het bijzonder waren aanleiding voor de NSV om op 13 maart 2009 een studiedag over de betekenis van Jacques van Doorn voor de Nederlandse sociologie te organiseren. Doel van deze dag was om niet alleen terug te kijken op de historische rol van Van Doorn, maar ook aandacht te besteden aan de actuele betekenis en veelzijdigheid van zijn ideeën. Daar heeft Van Doorn zelf ook alle aanleiding toe gegeven. Allereerst doordat hij zich op vele uiteenlopende terreinen heeft beziggehouden met actuele maatschappelijke vraagstukken als de kloof tussen de politiek en de burger, het integratievraagstuk, het nut van internationale militaire vredesmissies en de rol en betekenis van de sociologie in onze huidige, geïndividualiseerde samenleving. Daarnaast heeft hij een geheel eigen, meer tijdloos sociaal-wetenschappelijk perspectief geboden dat anderen ook nu nog volop mogelijkheden tot lering, inspiratie en tegenspraak biedt. Dit betekent dat Van Doorn zowel door de vraagstukken waarmee hij zich bezighield als de manier waarop hij dat deed een actuele intellectuele erfenis heeft nagelaten.

Tijdens de studiedag zijn zowel de meer algemene thema's aan de orde gesteld als twee concrete onderzoeksterreinen waarop Van Doorn een actieve rol heeft gespeeld. Met betrekking tot de eerstgenoemde thema's stond zowel de reflectie op de verhouding tussen de sociologie 
en de geschiedenis - de andere discipline waarin Van Doorn hoofdzakelijk actief is geweest - als de rol van de sociologie in het publieke debat centraal. De concrete onderzoeksterreinen waren sociologie en beleid enerzijds en sociologie en geweld anderzijds. Inleiders en co-referenten hebben Van Doorns opvattingen geplaatst in de hedendaagse discussie over deze thema's. De meesten van hen hebben hun bijdrage aan de studiedag uitgewerkt tot een hoofdstuk voor dit boek. Hieronder blikken we kort vooruit op hun bijdragen.

Deel I gaat over Van Doorn en de naoorlogse sociologie. Cor Lammers beschrijft de intellectuele nalatenschap van Van Doorn en typeert hem als een veelzijdige, systematische en visionaire wetenschapper die zich steeds minder ging bemoeien met de op- en uitbouw van de sociologie als wetenschappelijke discipline en steeds meer met het toepassen van de sociologische denktrant. Zo bezien is hij altijd blijven bijdragen aan wat Lammers beschouwt als de voornaamste rol van de sociologie: een gedistantieerde benaderingswijze van de controversiële sociale werkelijkheid en die bespreekbaar maken. Joop Ellemers staat stil bij de onlosmakelijke verbondenheid tussen de mens Van Doorn en zijn intellectuele inspanningen en bij de continuilteiten en discontinuïteiten in zijn werk. Het onderbouwen van zijn ideeën maakte Van Doorn ondergeschikt aan het genereren van tegenspraak. Dit deed hij niet alleen vanuit de overtuiging dat tegenspraak noodzakelijk was om totaliserende maatschappelijke tendensen tegen te gaan, maar ook vanuit een stijgend intellectueel besef dat het streven naar rationaliteit wellicht onvermijdelijk is, maar onherroepelijk gepaard gaat met blinde vlekken en onbedoelde gevolgen.

Deel II gaat over de verhouding tussen Van Doorn als socioloog en historicus. Wout Ultee toont zich kritisch over beide. Van Doorn zou eerder een functionalistisch perspectief hebben geboden dan falsifieerbare theorieën hebben ontwikkeld. En doordat hij zich concentreerde op zijn analytisch kader in plaats van op de onderbouwing ervan, heeft hij volgens Ultee nauwelijks bijgedragen aan dataverzameling waarvan hedendaagse historici profijt kunnen trekken en heeft hij bijvoorbeeld gegevens over de Duitse verkiezingsuitslagen in het interbellum onjuist geïnterpreteerd. Ten slotte zou Van Doorns aankondiging van het 'Herfsttij der democratie' het moeten stellen zonder aanbevelingen over hoe het tij te keren. Leonard Blussé stelt dat Van Doorns De laatste eeuw van Indië empirisch wel degelijk is onderbouwd door bronnenmateriaal dat vooral Wim Hendrix heeft aangedragen, dat hij concrete vraagstukken systematisch plaatste in een algemeen theoretisch kader, en dat het boek vooral geschiedkundig van belang is, doordat Van Doorn zich een meester toonde in het stellen van de juiste vragen. De fascinatie van Van Doorn voor Indië kwam volgens Blussé vooral voort uit het besef dat de 
de-institutionalisering van het huidige Nederlandse maatschappelijke bestel een spiegelbeeld vormde van de koloniale tijd in Indië: dat was een paradijs voor techneuten en ingenieurs.

Deel III handelt over Van Doorn als beleidssocioloog en publiek socioloog. Romke van der Veen schetst de intellectuele ontwikkeling die Van Doorn heeft doorgemaakt waar het de voortgaande rationalisering van de samenleving en een streven naar beheersing van maatschappelijke ontwikkelingen betreft. Hij startte als ontwerper van een toegepaste Rotterdamse beleidsopleiding en transformeerde in een scepticus die vooral oog had voor de onderdrukkende en perverse effecten van het streven naar rationaliteit en het maakbaarheidsgeloof dat ten grondslag ligt aan de verzorgingsstaat. Van der Veen trekt hieruit de les dat de sociologische beleidswetenschap een zorgvuldige, methodologische wetenschap vereist die is geënt op een systematische doordenking van theoretische en normatieve uitgangspunten: een combinatie van een waarheid zoekende en oriënterende functie. Dick Pels werpt de retorische vraag op of het toevallig is dat juist Pim Fortuyn en Jacques van Doorn een zeer zichtbare rol hebben gespeeld als publiek socioloog in de politieke scharnierjaren 2001-2002. De institutionele belemmeringen die de universiteit van nu opwerpt tegen de tegendraadsheid die zowel Fortuyn als Van Doorn kenmerkte, hadden immers geen vat op hen, aangezien zij de universiteit hadden verlaten. Van Doorn ontpopte zich als de meest gevreesde tegenstander van het rechtspopulisme van Fortuyn, maar slaagde er volgens Pels onvoldoende in het niveau van morele verontwaardiging over deze nieuwe politieke beweging te overstijgen.

Deel IV betreft Van Doorn en de militaire sociologie. René Moelker besteedt aandacht aan de blijvende waarde van de hypothesen die Van Doorn genereerde naar aanleiding van crises waarmee de krijgsmacht in het verleden is geconfronteerd. Van Doorn voorspelde de afschaffing van de dienstplicht en daarmee de opkomst van beroepslegers, hypothetiseerde over problemen rondom persoonsvorming die voortkwamen uit de spanning tussen de socialiserende en totaliserende eigenschappen van militaire internaten en werkte aan theorievorming door middel van historisch-sociologisch onderzoek naar de rationalisering van de militaire organisatie. Moelker concludeert dat vooral Van Doorns ideeën over de aard van de legitimiteitscrises van de krijgsmacht van blijvende waarde zijn, omdat ze inzicht verschaffen in transformatieprocessen. Casper Vroom vindt dat militaire sociologen een betrokken distantie behoren te bewaren ten opzichte van de krijgsmacht en toont zich daarmee noch een voorstander van kritische distantie noch van vereenzelviging. Volgens hem koos Van Doorn heel soms voor betrokken, maar meestal voor kritische distantie. Jan van der Meulen analyseert de houding van Van Doorn in zijn columns en essays ten aanzien van internationale militai- 
re missies. Volgens Van Doorn zijn interveniërende mogendheden zowel in Indië, Bosnië als Afghanistan in de fuik van gewelddadigheid gelopen als gevolg van de paradox dat 'militaire avonturen' om succes te kunnen boeken lang volgehouden moeten worden, maar naarmate de tijd verstrijkt meer verzet oproepen - niet alleen ter plekke, maar ook aan het thuisfront. Van der Meulen onderkent enerzijds de kracht van de historische analogie met het falen van koloniale machten, maar nuanceert deze anderzijds door te wijzen op Van Doorns beperkte empirische onderbouwing van zijn stelling, waardoor hij de fuik te zeer als onvermijdelijk voorstelde.

Het laatste deel is gewijd aan Van Doorn en de hedendaagse sociologie. Dick Houtman verdedigt de stelling dat er maar weinig terecht is gekomen van Van Doorns pleidooi voor cumulatie van sociologischtheoretisch inzicht via wederzijdse bevruchting van theorievorming en empirisch onderzoek. De professionalisering van de sociologie heeft volgens Houtman weliswaar geleid tot minder politieke vooringenomenheid, maar is ten koste gegaan van de maatschappelijke betekenis van het vak. Hij signaleert dat sociologen die graag wetenschappelijk willen zijn, niet geneigd zijn om de culturele betekenissen van de onderzochten erg serieus te nemen en pleit voor een cultuursociologie die dit laatste wel doet. In de slotbeschouwing betrekken we de verschillende bijdragen op elkaar. Dit leidt tot de conclusie dat Van Doorn als ideeënman nieuwe interpretaties heeft gegeven die bij sommigen tegenspraak uitlokken, anderen inspireren, maar die in elk geval leven in de sociologische brouwerij brengen. Dit geldt voor zijn functionalistische perspectief, zijn visie op de spanningsvolle verhouding tussen rationalisering en individualisering, zijn visie op de toekomst van de sociologie en de standpunten die hij innam ten aanzien van onder andere politiek, beleid, geweld en kolonisering.

Ten slotte willen we de instanties en personen bedanken die hebben geholpen bij de totstandkoming van dit boek. Onze dank gaat allereerst uit naar de NSV, als initiatiefnemer van de studiedag waarvan deze bundel het resultaat is, en naar de Nederlandse Defensie Academie in Breda (de vroegere KMA, waaraan Van Doorn geruime tijd als hoogleraar verbonden is geweest), die op deze dag als gastheer optrad. De afdeling Sociologie van de Rotterdamse Erasmus Universiteit, waarvan Van Doorn de grondlegger was en waaraan hij het overgrote deel van zijn universitaire loopbaan verbonden was, danken wij voor haar financiële bijdrage die de verschijning van deze bundel mede mogelijk heeft gemaakt.

Naast deze instanties willen wij ook twee personen bedanken. Allereerst Michelle Schut die een belangrijk deel van de eindredactie van de bundel voor haar rekening heeft genomen. Daarnaast natuurlijk Cor 
Lammers. Hij heeft niet alleen een actieve en betrokken rol gespeeld bij de organisatie van de studiedag, maar hield op de dag zelf (naar later bleek slechts twee weken voor zijn overlijden) ook een enthousiasmerende lezing, waarin hij appelleerde aan de verbondenheid van alle aanwezigen met de sociologie. Daarmee bracht hij tevens zijn eigen nauwe persoonlijke en intellectuele verbondenheid met Van Doorn tot uitdrukking.

Jacques van Hoof, Dick Houtman, Peter Mascini, René Moelker en Sjo Soeters Juli 2010 

Deel I

Van Doorn en de naoorlogse sociologie 



\title{
I In memoriam J.A.A. van Doorn
}

\author{
Cor Lammers
}

Woensdag 14 mei 2008 overleed - in de leeftijd van 83 jaar - Jacques van Doorn (officieel Jacobus Adrianus Antonius), ontegenzeggelijk 'de' centrale figuur van de naoorlogse ontwikkeling van de sociologie in Nederland. Voor en na zijn dienstplicht (van 1947 tot begin 1950 in Indië/Indonesië), studeerde hij sociale geografie aan de Universiteit van Amsterdam, waar hij in 1951 slaagde voor het doctoraal examen. Al direct na zijn eindexamen hbs in de oorlogsjaren had hij de sociologie ontdekt en beoefend en trouwens óók tijdens zijn diensttijd in Indië zette hij die studies voort. Hij kon zich dus terecht als een autodidact beschouwen en hiermee is dan meteen al een saillante karakteristiek van Van Doorn aangeduid: een enorme werkkracht en zelfdiscipline!

Zijn energie en initiatief kwamen al vanaf het begin van zijn studie en loopbaan tot uiting in een ononderbroken stroom van publicaties van zijn hand, maar vooral als gangmaker ${ }^{1}$ van de Nederlandse sociologie na de Tweede Wereldoorlog. In de jaren vijftig nam hij het voortouw tot de oprichting van een specifiek vakblad voor 'sociologie en sociaal onderzoek', de Sociologische gids - als tegenhanger van het reeds sinds 1925 bestaande Mens en maatschappij - en fungeerde jarenlang als redactiesecretaris en tevens als de-facto-voorzitter van de redactie. Uit hoofde van zijn functie als adjunct-directeur van het Instituut voor Sociaal Onderzoek van het Nederlandse Volk (ISONEVO), de voorloper van het latere SISWO, stimuleerde hij diverse jongere sociologen in het entameren en uitvoeren van onderzoek. Minder bekend is zijn rol als actievoerder/lobbyist om zijn medestander Gé Kruijer door de Amsterdamse gemeenteraad - zulks in afwijking van de voordracht van de faculteit! - benoemd te krijgen als hoogleraar sociografie. ${ }^{2}$

In een magistrale dissertatie (1956) waarin hij de sociologie van de organisatie lanceerde aan de hand van een historische studie over de 
ontwikkeling van de militaire organisatie, gaf hij tevens een interessante vergelijking ten beste van deze ontwikkeling met die van de industriele organisatie. In 1958 werd hij hoogleraar in Leiden, waar hij plannen ontwierp voor de zogenaamde 'industriële sociologie', een programma waar hij echter pas in Rotterdam - waarheen hij in 1960 vertrok - de ruimte voor kreeg in het kader van een nieuwe, door hemzelf te 'bouwen' sociale faculteit.

Met zijn dissertatie gaf hij een aanzet, dan wel een flinke impuls tot de (verdere) ontplooiing van een drietal sociologische specialisaties, te weten de sociologie van de organisatie, de industriële sociologie en de militaire sociologie. Eind jaren vijftig kwam echter óók - dit jaar precies een halve eeuw geleden! - zijn primaire bijdrage tot de algemene sociologie tot stand in de vorm van Moderne sociologie (1959). Als mede-auteur van dit werk ben ik niet de meest geëigende figuur om over de betekenis ervan een oordeel te vellen, maar wel meen ik in staat - en ertoe verplicht - te zijn om in het kader van dit levensbericht enige misverstanden recht te zetten. Ten eerste, Moderne sociologie is niet - zoals vaak beweerd wordt de meest gebruikte en/of meest verkochte Nederlandse inleiding in de sociologie. In 1964 verscheen een nieuw leerboek op het terrein van de sociologie van De Jager en Mok (Grondbeginselen der sociologie) waardoor aanzienlijk meer studenten met het vak kennismaakten dan via ons boek.

Ten tweede, er is wel gezegd - onder andere in het VPRO-marathoninterview met Van Doorn (juli 2007) - dat Moderne sociologie indertijd 'de bijbel' geweest zou zijn voor de naoorlogse generatie sociologen. Daarbij moet dan wel vermeld worden dat, hoevelen ook in en over ons boek gelezen hebben, - helaas evenals in het geval van de bijbel! - het gezegde 'jong geleerd, oud gedaan' niet van toepassing is, want slechts weinig sociologen hebben het in dit boek geboden theoretisch kader integraal toegepast.

Niettemin, vele Nederlanders en Vlamingen hebben aan Moderne sociologie een begrip, een inzicht ontleend dat hun sindsdien in de mond is bestorven. Zo zou het mij niet verbazen als onze geachte ministerpresident Balkenende de Aula-pocket nummer 29 in kwestie nog in zijn boekenkast heeft staan en goed onthouden heeft dat welbekende begrippen als waarden en normen essentiële ingrediënten van een cultuur vormen.

Bovendien en bovenal, Moderne sociologie verschafte een samenhangende visie op wat de sociologie in die dagen vermocht en dat maakte in veler ogen de pretentie waar van een veelbelovend, wetenschappelijk perspectief op mens en maatschappij. Deed in die naoorlogse jaren de opvatting opgeld dat het bij sociologie en andere sociale wetenschappen om waardegebonden disciplines ging, hier werd een professioneel 
- zoal niet waardevrij, dan toch waardeneutraal - totaaloverzicht geboden. Tot eind jaren zestig heerste er dan ook in de Nederlandse sociologie een noch voor- noch nadien geëvenaarde mate van esprit de corps. Er was sprake van een zekere mate van convergentie in begripsvorming en methodologie en dat ging gepaard met een zeker vooruitgangsgeloof omtrent de heilzame en cumulatieve wisselwerking tussen de constructie van theorieën van beperkte draagwijdte (Merton) en gedegen empirisch onderzoek. De sociologie was - of leek? - een tot wasdom gekomen, erkende maatschappijwetenschap die zich kon meten met, maar ook wat te bieden had aan, oudere universitaire disciplines zoals antropologie, economie, geschiedenis of rechtsgeleerdheid. ${ }^{3}$

Eind jaren zestig ontbrandde echter een forse paradigmastrijd in de wereld der sociale, of ruimer nog: maatschappijwetenschappen. De mening won veld dat er bij theorievorming altijd sprake zou zijn van een 'kennisleidend belang' of van een allesoverheersend methodologisch grondbeginsel. Hierbij ging het om een veelheid van uitgangspunten die per definitie betekenen dat er zelden of nooit sprake is van de sociologie, maar slechts van een bonte verzameling sociologieën.

In deze woelige jaren beijverden Van Doorn en Lammers zich om hun inmiddels in rook vervlogen hoop op 'convergentie in het sociologisch denken en onderzoeken (...) die tot een geïntegreerd wetenschapssysteem begint te leiden' (Van Doorn en Lammers 1959: 11) bij te stellen en een zekere pluriformiteit als onvermijdelijk te aanvaarden. Omdat met name Van Doorn zich naderhand wel eens wat gedistantieerd heeft van ons 'jeugdwerkje', heeft dit mijns inziens soms geleid tot een derde misverstand, als zou de opzet, de systematiek van Moderne sociologie voornamelijk mijn werk zijn geweest. ${ }^{4}$ Ofschoon ik mijn inbreng in dit project geenszins wil bagatelliseren, moet ik er toch met nadruk op wijzen dat Jacques van Doorn Moderne sociologie terecht als primair zijn geesteskind beschouwde. In eerste instantie bracht ik niet veel meer in dan het onderscheid tussen de kerndimensies (sociale afstand, sociale rang, sociale integratie) en de verdere op- en uitbouw was een vrucht van Van Doorns sociologische verbeeldingskracht en uiteraard óók van onze interactie. Trouwens, hij was ook degene die in de jaren zeventig het initiatief tot een herziene (13de) druk nam, concludeerde dat we de oorspronkelijke versie intact moesten laten, konden volstaan met aanvullend commentaar en aanbevolen literatuur en - evenals trouwens de eerste keer! - het leeuwendeel der werkzaamheden verrichtte.

Bovendien dient men te beseffen dat Van Doorn, hoewel tegenwoordig vooral bekend als sociologisch essayist en columnist, de kunst van het systematiseren en analyseren zeer wel verstond, getuige de opzet en uitwerking van bijvoorbeeld zijn proefschrift, of ook van zijn voordracht voor de Nederlandse Sociologische Vereniging over Sociologische begrippen 
en problemen rond het verschijnsel macht (1957). Met andere woorden, ook in de concipiëring en systematische uitwerking van een abstract-wetenschappelijke verhandeling toonde hij zich een meester.

Hiermede zijn wij eigenlijk al aangeland bij een van Van Doorns meest markante vaardigheden, zijn grote intellectuele spanwijdte, zijn formidabel bevattingsvermogen om allerlei uiteenlopende gegevens, redeneringen of gezichtspunten als het ware in een overkoepelend kader in- en overzichtelijk te maken. Hij deed dat op een zakelijke, niet zwaarwichtige, soms ietwat ironische manier. Natuurlijk kwam deze capaciteit hem te stade niet alleen in zijn eigen wetenschappelijk werk, maar tevens in zijn rol als gangmaker, want zodoende kon hij vakgenoten van diverse pluimage bij elkaar brengen, enthousiasmeren en hun krachten bundelen.

Zo kon hij in soms nogal warrige discussies een rode draad onderkennen, een essentie of conclusie ontdekken waarmee iedereen vrede kon hebben. Uit hoofde van deze vaardigheid was hij ook 'gewild' als dagvoorzitter of 'slotbeschouwer' van conferenties, zoals destijds onze jaarlijkse BSS (Bedrijfssociologische Studiedagen). Trouwens, óók in internationaal verband onderscheidde hij zich van de doorsnee discussieleider die doorgaans niet veel meer doet dan discussianten het woord geven en - doorgaans te laat - ontnemen. Jacques van Doorn liet allerlei veelal disparate op- en aanmerkingen van participanten niet als losse eindjes hangen, maar gaf ze een plaats in een groter geheel. Dan kan zo'n 'metaperspectief' niet slechts op zich waardevol zijn, maar ook de geëncadreerde kleine deeltjes soms nog een zekere meerwaarde verlenen.

Overigens lagen zijn internationale bijdragen hoofdzakelijk op het terrein van de militaire sociologie, studies over onder meer de militaire professie en organisatie, de wisselwerking tussen krijgsmacht en samenleving, ideologie en legitimering van das Militär. Zijn waaier van activiteiten in deze branche van de sociologie vloeide uiteraard voort uit zijn promotiestudie en werd in sterke mate gestimuleerd door zijn benoeming (in 1962) tot buitengewoon hoogleraar aan de KMA. Naar mijn indruk beleefde hij minstens evenveel, zo niet meer plezier aan zijn onderwijs aan cadetten en verdere bezigheden op de KMA dan aan zijn universitaire taken. In het verlengde hiervan leverde hij de nodige bijdragen aan conferenties en periodieken in de Nederlandse militaire wereld en voorts ondernam hij - tezamen met de Amerikaanse socioloog Morris Janowitz - geslaagde pogingen voor het oprichten van een sectie voor militaire sociologie (Armed Forces and Conflict Resolution) in het kader van de International Sociological Association, van een tijdschrift genaamd Armed Forces and Society en van het Inter-university Seminar on Armed Forces and Society, een instantie die - nog steeds! - conferenties op dit terrein organiseert. ${ }^{5}$ 
Terug naar eind jaren vijftig. In Leiden bleek Van Doorn al spoedig te weinig ontplooiingsruimte te krijgen. Reeds na twee jaar vertrok hij (in 1960) naar Rotterdam, eerst als hoogleraar in de faculteit der economische wetenschappen, maar al spoedig als 'bouwdecaan' van een 'eigen' sociale faculteit. In deze opleiding konden studenten zich voorbereiden op nieuwe beroepsmogelijkheden als 'praktijksocioloog', te weten als bedrijfs- of bestuurskundig, of ook als sociaal-economisch beleidssocioloog. Ook al in zijn Leidse tijd - zijn oratie van 1958 ging over Relevantiekaders der industriële sociologie - was Van Doorn in de weer met het probleem hoe de denktrant, bevindingen en inzichten van de sociologie toepasbaar te maken.

Anders dan de jurist of econoom, zo luidde ongeveer zijn gedachtegang, heeft een afgestudeerd socioloog geen direct aanwendbare vakkennis. De 'praktijksocioloog' kan alleen wat uitrichten door uit te gaan van 1) een theoretisch goed doordacht en wetenschappelijk verantwoord analysekader en door 2) zich te engageren, zich te verdiepen in een bepaalde maatschappelijke problematiek én in de mogelijkheden om daar zelf wat aan te doen, dan wel bij te dragen aan pogingen hiertoe van, of met anderen.

Deze twee eisen kunnen onderling strijdig zijn en dat dilemma heeft Van Doorn aardig verwoord in zijn Rotterdamse oratie (1961) met de uitspraak dat een goede socioloog 's morgens opstaat met het vaste voornemen zich niet door de maatschappij op sleeptouw te laten nemen en zich 's avonds vóór het naar bed gaan afvraagt of hij die dag met zijn vak wel genoeg voor de maatschappij heeft gedaan! Nu zijn vele, zo niet de meeste praktijksociologen 's morgens vroeg al van zins alleen als het zo uitkomt met, maar anders zonder, sociologie aan de slag te gaan, terwijl het gros der 'academische sociologen' van 's morgens vroeg tot 's avonds laat alleen maar aan het vak denkt. Er zijn echter natuurlijk ook - zeker in Nederland! - dezulken die proberen het juiste midden te houden en consciëntieus gebruik te maken van hun professionele kennis en vaardigheden. Zijn zij zich het dilemma wel bewust, voor Jacques van Doorn was het bijkans een spagaat.

In het begin van zijn loopbaan is hij vooral een geleerde, geïnteresseerd in - en druk in de weer met - de ontwikkeling van zijn vak. Daarna als hoogleraar gaat hij zich hoe langer hoe meer bezighouden zowel in de opleiding als ook in zijn eigen studiën met de mogelijkheden en moeilijkheden van de beleidstoepassing van sociologie en andere sociale wetenschappen. Het accent verschuift van Van Doorn als wetenschapper pur sang - zo gezegd als 'ochtendmens' - naar Van Doorn als 'avondmens', als praktijkgericht onderzoeker dan wel als sociaal-wetenschappelijke analist van en commentator op eigentijdse vraagstukken. Zo richtte hij met enige medestanders in 1973 Beleid en maatschappij op, een nog steeds 
florerend tijdschrift voor 'wetenschappelijk verantwoorde analyses van beleidsontwikkelingen in de samenleving binnen de spanningsverhouding tussen beleid, wetenschap en de publieke zaak'. Hierin verschenen vele bijdragen van zijn hand waarin hij zijn visie in de geest van het programma van zijn Rotterdamse oratie, toepast en uitwerkt. In zekere zin een sluitstuk, maar hoe dan ook een fraai hoogtepunt in dit genre van wat hij noemde 'secundaire reflectie', ${ }^{6}$ vormt zijn boek Rede en macht (1988). In de na zijn dood verschenen, door De Beus en De Rooy bezorgde, bundel Nederlandse democratie (2009) is een groot aantal van deze op een breed publiek gerichte bijdragen van de hand van de 'late' Van Doorn bijeengebracht.

Overigens, de hier geschetste verlegging van Van Doorns aandachtsveld had ongetwijfeld óók - zo niet alles - te maken met de ontwikkelingen in de Nederlandse universitaire wereld in het algemeen en in de Erasmus Universiteit Rotterdam in het bijzonder. Zo ontstonden soms hooglopende controversen in de Sociale Faculteit (onder andere over verdere differentiatie van opleidingstrajecten en met name ook inzake het studentenprotest eind jaren zestig, begin jaren zeventig) en nog later werd de 'Rotterdamse formule' bedreigd en verder gehavend ten gevolge van de Haagse bezuinigingsoperaties. Als resultaat van deze ontwikkelingen raakte Jacques van Doorn verbitterd en vervreemd van zijn faculteit en universiteit en ging hij in 1987 met vervroegd emeritaat.7

Intussen, ook in de laatste decennia van de twintigste eeuw, publiceerde hij naast deze toepassingsgerichte of beleidsrelevante essays nog vele interessante bijdragen over themata vanuit een sociologische optiek. Zo vatte hij in de jaren zeventig de draad weer op van zijn Indische ervaringen. In 1970 publiceerde hij (tezamen met zijn vroegere wapenbroeder, W.J. Hendrix) Ontsporing van geweld: Over het Nederlands/ Indisch/Indonesisch conflict, wat later (1973): Orde-opstand-orde. Naderhand werkte hij in Rotterdam tezamen met Jan Breman en Wim Hendrix in het kader van het Comparative Asian Studies Programme aan studies over de problemen en ontwikkelingen in het heden en verleden van Indonesië. Na zijn emeritaat in 1987 resulteerde dit onder meer in De laatste eeuw van Indië: Ontwikkeling en ondergang van een koloniaal project (1994) - mijns inziens zijn magnum opus! - en het jaar daarop Indische lessen: Nederland en de koloniale ervaring (1995). Daarnaast behandelde hij in zijn columns analyses en opinies over - doorgaans actuele - onderwerpen en verder nog in boekvorm over onder meer Zuid-Afrika (1991), generaties (2002) en nog recent over de ontwikkelingen van het Duitse socialisme (2007). In deze verspreide geschriften - en trouwens ook in zijn beleids- en toepassingsgericht werk - vermeed hij zoveel mogelijk het vakjargon, maar de sociologische fijnproever hoefde doorgaans het vakperspectief niet met een lantaarntje te zoeken! 
Kortom, zoals al eerder in dit levensbericht aangestipt, Van Doorn hield zich in de latere decennia van zijn werkzame leven steeds minder bezig met de op- en uitbouw van ons vak, maar meer met het toepassen van de sociologische denktrant, in de woorden van Ralph Dahrendorf (1970), meer met de Weltbild- dan met de Fachsoziologie. Helaas ging deze ontwikkeling - in termen van zijn eigen schets van het dilemma van de socioloog: van 'ochtend'- tot 'avondmens' - gepaard met een toenemende scepsis betreffende de relevantie en mogelijkheden van de sociologie in de hedendaagse samenleving. Zo betoogde hij in een interview aan de vooravond van zijn benoeming tot erelid van de Nederlandse Sociologische Vereniging in april 1986 dat, ten gevolge van de vergaande deinstitutionalisering van ons huidig maatschappijbestel, de sociologie niet veel meer te bieden had (De Rijk 1986). ${ }^{8}$

Omdat hij zelf rustig doorging met het aanwenden van het sociologisch perspectief voor de analyse van - en het inzicht in - de turbulenties van de moderne wereld, heb ik aan zijn pessimisme in dezen nooit al te zwaar getild. Bovendien, bij de naoorlogse generatie sociologen waren de verwachtingen niet alleen omtrent de verdere ontwikkeling van het vak, maar ook over de relevantie ervan, wel erg hooggespannen. In die tijd van de wederopbouw na 1945 stond velen - als model van een praktijksocioloog - het beeld van een ingenieur of econoom voor ogen, met andere woorden, van een academicus die alleen al dankzij zijn professionele opleiding beschikt over min of meer direct toepasbare kennis en vaardigheden. Pas langzamerhand rijpte het besef dat de sociologie zich gesteld ziet voor de immense taak om de veelkleurige en vaak snel veranderende sociale werkelijkheid via in taal weer te geven theorievorming onderzoeksrijp te maken. In de taal en derhalve eveneens in de theorievorming en het empirisch onderzoek, reflecteert zich echter ook een veelheid aan ideologische, nationale of tijdsgebonden eigenaardigheden. Ten gevolge van deze pluriformiteit komt het slechts in beperkte mate tot een cumulatieve opbouw van algemeen aanvaarde wetenschappelijke kennis. Van erkende - specifiek sociologische - professionele vaardigheden, afgezien dan van een objectiverende en analyserende denktrant, is in het geval van de sociologie al helemaal geen sprake. Geen wonder dus dat nogal wat sociologen teleurgesteld raakten in het heilzaam vermogen van hun vak, maar mijns inziens hoeft dat geen reden te zijn om aan de 'roeping' van het vak te wanhopen. Immers, juist dankzij deze pluriformiteit kan de sociologie - en dat geldt algemeen voor alle sociale wetenschappen - bijkans 'elk wat wils' bieden en zodoende toch bijdragen aan een gedistantieerde benaderingswijze van de veelal zo controversiële sociale werkelijkheid en aan het bespreekbaar maken daarvan.

Deze laatste weg was duidelijk de keuze van Van Doorn als analist van hedendaagse problematiek en van actueel beleid. Derhalve kunnen 
wij hem gedenken niet slechts als een gangmaker die na de oorlog op diverse gebieden een succesvolle 'herstart' van de sociologie bewerkstelligde, maar ook als een allround intellectueel en sociale wetenschapper die in ons land althans een deel van de spraakmakende gemeente zowel van links als van rechts aan het denken zette en haar hopelijk ook noopte tot verstandiger spreken en gesprek over de weerbarstige vraagstukken van mens en maatschappij in de afgelopen halve eeuw.

\section{Noten}

1. De typering is afkomstig van Ellemers (1985: xxix) die hem zo karakteriseert met betrekking tot zijn inspanningen om in Rotterdam een eigen sociologie-opleiding van de grond te krijgen. Ellemers schetste Van Doorn in 1985 ter gelegenheid van diens 25-jarig ambtsjubileum als hoogleraar te Rotterdam. Deze schets vormde voor mij een bron waarvan ik dankbaar gebruik maakte om allerlei gebeurtenissen of publicaties van Van Doorn te signaleren of te verifiëren.

2. In die tijd was de UvA nog een gemeentelijke instelling zodat de gemeenteraad ook een hoogleraar die niet op de voordracht van de faculteit stond, kon benoemen, hetgeen in het geval van Kruijer aldus geschiedde!

3. Zelf heeft Van Doorn in zijn op één na laatste boek Gevangen in de tijd (2002: 170179) deze naoorlogse professionalisering en institutionalisering van de Nederlandse sociologie geschetst als een generatieconflict tussen sociografen en sociologen zonder daarbij zijn eigen alleszins saillante rol in het licht te stellen!

4. Dit suggereert Van Doorn bijvoorbeeld in een interview met Piet Nijhoff en Dick Pels (1985).

5. Over de militaire sociologie in Nederland in het algemeen en Van Doorns rol daarin: Soeters (2000) en voorts over Van Doorn en het sociologie-onderwijs aan de KMA/NLDA: Moelker en Soeters (2008).

6. Hij gebruikte deze term vaak in de redactievergaderingen van Beleid en Maatschappij en duidde daarmee aan een begripsmatige analyse van een probleem in een historisch-sociale context door een onafhankelijk wetenschapsbeoefenaar (persoonlijke mededeling van Kees Schuyt).

7. Over deze ontwikkelingen in de Rotterdamse FSW vanaf eind jaren '6o waarmee Van Doorn werd geconfronteerd, en over hoe hij daarop reageerde, zie Dicke (2003).

8. Zie hierover ook Laeyendecker (1986). Relevant in dit verband is voorts een veel later artikel (Van Doorn 200o) waarin hij de 'crisis' van de sociologie wat relativeert door die te schetsen als een algemene problematiek van de sociale wetenschappen in het huidig tijdsgewricht en voorts door een wat optimistischer toon over de toekomst van de sociologie die hij in zijn slotconclusies laat horen.

\section{Geraadpleegde literatuur}

Dahrendorf, R. (1970), 'Vom Nutzen der Soziologie', in: Th.W. Adorno et al., Soziologie zwischen Theorie und Empirie: Soziologische Grundprobleme, München: Nymphenburger Verlagshandlung, p. 13-24.

Dicke, M. (2003), 40 jaar FSW. De Rotterdamse formule in de praktijk, Rotterdam: Stad en Bedrijf/ FSW EUR. 
Doorn, J.A.A. van (1956), Een sociologische benadering van het organisatieverschijnsel in het bijzonder gebaseerd op een analyse van de militaire organisatie, Leiden: Stenfert Kroese.

Doorn, J.A.A. van (1957), 'Sociologische begrippen en problemen rond het verschijnsel macht', in: Sociologisch jaarboek 11: 73-122 (later herdrukt in: J.A.A van Doorn, (1966), Organisatie en maatschappij. Sociologische opstellen, Leiden: Stenfert Kroese).

Doorn, J.A.A. van (1958), Relevantiekaders der industriële sociologie, inaugurele rede Rijksuniversiteit Leiden, Leiden: Stenfert Kroese.

Doorn, J.A.A. van (1961), Arbeidsmarkt en arbeidsbestel, inaugurele rede Nederlandse Economische Hogeschool, Leiden: Stenfert Kroese.

Doorn, J.A.A. van (1973), Orde-opstand-orde. Notities over Indonesië, Meppel: Boom.

Doorn, J.A.A. van (1988), Rede en macht. Een inleiding tot beleidswetenschappelijk inzicht, 's-Gravenhage: VUGA.

Doorn, J.A.A. van (1991), Een kwestie van overleven. Notities over Zuid-Afrika, Amsterdam: Meulenhoff.

Doorn, J.A.A. van (1994), De laatste eeuw van Indië. Ontwikkeling en ondergang van een koloniaal project, Amsterdam: Bert Bakker.

Doorn, J.A.A. van (1995), Indische lessen. Nederland en de koloniale ervaring, Amsterdam: Bert Bakker.

Doorn, J.A.A. van (2000), 'Sociale wetenschappen en de weerbarstige werkelijkheid', in: P.B. Lehning (red.), De beleidsagenda 20oo. Strijdpunten op het breukvlak van twee eeuwen, Bussum: Coutinho, p. 24-41.

Doorn, J.A.A. van (2002), Gevangen in de tijd. Over generaties en hun geschiedenis, Amsterdam: Boom.

Doorn, J.A.A. van (2007), Duits socialisme. Het falen van de sociaal-democratie en de triomf van het nationaal-socialisme, Amsterdam: Mets \& Schilt.

Doorn, J.A.A. van (2009), Nederlandse democratie. Historische en sociologische waarnemingen, Amsterdam: Mets \& Schilt.

Doorn, J.A.A. van en C.J. Lammers, (1959), Moderne sociologie. Systematiek en analyse, Utrecht: Het Spectrum.

Doorn, J.A.A. van en W.J. Hendrix (1970), Ontsporing van geweld. Over het Nederlands/Indisch/Indonesisch conflict, Rotterdam: Universitaire Pers.

Ellemers, J.E. (1985), De man en zijn werk. De bijdrage van J.A.A van Doorn aan de beoefening van de sociologie in Nederland, Rotterdamse Rapportenreeks Sociale Wetenschappen nr. 1, Rotterdam: Erasmus Universiteit. Jager, H. de en A.L. Mok (1964), Grondbeginselen der sociologie, Leiden: Stenfert Kroese.

Laeyendecker, L. (1986), 'Uit de erehemel scepsis', Sociodrome 4: 3-10.

Moelker R. en J. Soeters (2008), 'Van Doorn and Beyond. From Teaching Sociology to Interdisciplinary, Problem-based Learning in Dutch Officer Training', Armed Forces and Society 35: 36-48. 
Nijhoff, P. en D. Pels (1985), 'Van Doorn en Lammers over "Van Doorn en Lammers" ', Sociodrome 3: 2-8.

Rijk, M. de (1986), 'Een socioloog wordt ook maar geleefd', NRC Handelsblad, 3 april 1986.

Soeters, J.L. (2000), 'Military Sociology in the Netherlands', in: G. Kümmel en A.D. Prüfert (red.), Military Sociology, Baden-Baden: Nomos Verlagsgesellschaft, p. 128-139. 


\title{
2 J.A.A. van Doorn als socioloog \\ Continuïteit en discontinuïteit
}

\author{
J.E. Ellemers ${ }^{1}$
}

Op 14 mei 2008 overleed Jacobus Adrianus Antonius van Doorn. Hij was een van de bekendste Nederlandse sociologen uit de tweede helft van de twintigste eeuw. In bepaalde opzichten vormt hij een soort trait d'union tussen de eerste generatie naoorlogse sociologen, zoals P.J. Bouman, Sj. Groenman, F. van Heek, E.W. Hofstee, A.N.J. den Hollander en J.P. Kruijt, die vooral bekendheid verwierven in de jaren vijftig en zestig, en een generatie sociologen, die in latere decennia naar voren kwam, zoals bijvoorbeeld J. Goudsblom, C.J.M. Schuyt, A. de Swaan, W.C. Ultee en A.C. Zijderveld. Tegelijkertijd omspant Van Doorns werk de gehele periode van de jaren vijftig tot en met de eerste acht jaar van de eenentwintigste eeuw. Hij heeft daarbij voortdurend opengestaan voor zowel het werk van de 'oudere' generatie, als dat van 'jongeren'. Toch is zijn plaats in de Nederlandse sociologie betrekkelijk uniek. Hij was zeer goed op de hoogte van het werk van anderen, leverde daar vaak commentaar op en verwerkte het in zijn eigen geschriften, maar volgde wel een eigen weg. Hij werkte veel en nauw samen met anderen, te beginnen met C.J. Lammers in Moderne sociologie (eerste druk 1959; herziene uitgave 1976; 15de druk 1984), met W.J. Hendrix in Ontsporing van geweld (1970; herziene uitgave 1983), voorts in talloze bundels die hij met anderen schreef of redigeerde. Maar uiteindelijk was en bleef hij toch vooral een solist, met zeer eigenzinnige en vaak dwarse opvattingen.

Goed beschouwd is het niet zo eenvoudig het werk van Van Doorn als socioloog te karakteriseren. Enerzijds is er grote continuilteit in zijn werk en de thema's waar hij zich mee bezighield: (militaire) organisatie, het koloniale Indië en postkoloniale Indonesië, de verzorgingsstaat in al zijn aspecten, de Nederlandse politiek. Anderzijds zijn er ook spanningen en soms moeilijker te identificeren veranderingen in zijn visies, zoals bijvoorbeeld over beleid en de 'professionele rol' van de socioloog 
of over de multiculturele samenleving. Alvorens hier nader op in te gaan wil ik eerst een beknopte schets geven van zijn carrière als socioloog en publicist. $^{2}$

\section{Van zelfstudie tot bekend hoogleraar en publicist}

Jacques van Doorn werd geboren op 5 maart 1925 in Maastricht, waar hij ook lager en middelbaar onderwijs volgde. Omdat hij midden in de Tweede Wereldoorlog eindexamen deed en de Nederlandse universiteiten inmiddels waren gesloten, begon hij een zelfstudie in de sociale geografie onder leiding van zijn voormalige leraar H.A.W. Beijer. Toen hij zich in 1945 als eerstejaarsstudent bij de Universiteit van Amsterdam inschreef, had hij al enkele scripties gereed, waaronder 'De economische geest te Maastricht', die in 1947 gepubliceerd zou worden in Mensch en maatschappij.

$\mathrm{Na}$ in 1946 het kandidaatsexamen te hebben afgelegd werd hij in oktober van dat jaar dienstplichtig militair en verbleef van juli 1947 tot maart 1950 in Indonesië. Behalve dat deze ervaringen de aanleiding en basis zouden vormen van zijn proefschrift, verzamelden Hendrix en hij toen ook het materiaal voor hun latere gezamenlijke studie Ontsporing van geweld. Het was verder een periode van voortgezette zelfstudie, waarin hij onder andere Marx, Spengler en Nietzsche las.

Terug in Nederland studeerde hij in 1951 af en verrichtte als assistent van de destijds nieuwe hoogleraar sociale geografie, H.D. de Vries Reilingh, een onderzoek naar de toekomstperspectieven van afgestudeerden in de sociale wetenschappen (1952). Na een leraarschap aan een middelbare school in Bilthoven werd hij in 1954 adjunct-directeur en in 1956 directeur van het ISONEVO, het Instituut voor Sociaal Onderzoek van het Nederlandse Volk, dat later vervangen zou worden door SISWO.

Ondertussen was Van Doorn ook medeoprichter en vanaf eind 1953 de eerste redactiesecretaris en drijvende kracht van de Sociologische gids en publiceerde hij zijn eerste boek, De proletarische achterhoede (1954). In 1956 promoveerde hij aan de Leidse Universiteit bij Van Heek op Een sociologische benadering van het organisatieverschijnsel. In 1958 werd hij buitengewoon hoogleraar industriële sociologie aan de Rijksuniversiteit Leiden en in 1959 verscheen de eerste druk van Moderne sociologie, dat jarenlang het toonaangevende studieboek in de Nederlandse sociologie zou zijn. (Daarnaast was er ook nog het boek van H. de Jager en A.L. Mok, Grondbeginselen der sociologie, dat nog grotere oplagen had, maar vooral op hboniveau werd en nog steeds wordt gebruikt.)

In 1960 werd Van Doorn gewoon hoogleraar sociologie aan de toenmalige Nederlandse Economische Hogeschool (NEH), de latere Erasmus Universiteit. Hier zou hij een centrale rol gaan spelen in de enkele jaren 
later opgerichte Faculteit der Sociale Wetenschappen en de gangmaker worden van de 'Rotterdamse formule', een opleidingsprogramma gericht op toepassing en beleid. Mede door de onrust aan de Nederlandse universiteiten sinds het eind van de jaren zestig en - als gevolg daarvan - allerlei animositeit, nam Van Doorn geleidelijk afstand van zijn geesteskind. Hij hield zich opnieuw actief bezig met militaire sociologie, vooral in internationaal verband, publiceerde over maatschappelijke en politieke mobilisatie en verzorgde Nederlandse uitgaven van het werk van Michels, Etzioni en Goffman. Van 1962 tot 1972 was hij tevens buitengewoon hoogleraar sociologie aan de Koninklijke Militaire Academie (KMA) te Breda.

In de loop van de jaren zeventig en tachtig opereerde hij steeds meer aan de grenzen van de Nederlandse sociologie. Sinds 1973 was hij zeer actief in het interdisciplinaire tijdschrift Beleid en maatschappij, waarvan hij medeoprichter en eerste redactievoorzitter was. Rond dit tijdschrift redigeerde hij eveneens boekuitgaven over speciale onderwerpen met betrekking tot beleid en politiek, maar ook hield hij zich opnieuw bezig met Indië en Indonesië. Hij vervulde tal van nevenfuncties, waaronder die van kroonlid van de Sociaal Economische Raad.

In 1987 verliet Van Doorn voortijdig de universiteit met een de aandacht trekkende afscheidsrede, Relativering van rationaliteit, die een jaar later gevolgd werd door een omvangrijke uitwerking in boekvorm: Rede en macht. Een inleiding tot beleidswetenschappelijk inzicht. Ook na zijn emeritaat bleef Van Doorn - tot vlak voor zijn overlijden - publicistisch zeer actief met studies over het koloniale Indië, over generaties en een jaar voor zijn dood met de uitdagende studie Duits socialisme. Daarnaast schreef hij wekelijkse columns, eerst in Economisch-Statistische Berichten en NRC Handelsblad, later in HP/De Tijd en Trouw, die hem - ver buiten de grenzen van de sociologie - de laatste tientallen jaren van zijn leven tot een vooraanstaand, maar soms ook omstreden, opinieleider binnen de nationale spraakmakende gemeente maakte. In deze columns prevaleerden echter eveneens de visies van een socioloog.

\section{Continuïteit in een kolossaal oeuvre}

Het werk van Van Doorn kan kolossaal worden genoemd. Het bevat minstens honderd publicaties in boekvorm, waarvan Van Doorn de auteur, mede-auteur of redacteur was. Verder zijn er honderden bijdragen aan bundels en artikelen en boekbesprekingen in wetenschappelijke tijdschriften. De bibliografie van zijn geschriften, die in 1985 werd samengesteld - dus tot zijn zestigste jaar - telde reeds 275 wetenschappelijke geschriften (Terlouw 1985). In de 23 jaar daarna zijn daar - schat ik - nog wel 100 tot 150 titels bijgekomen. We komen dan tot een totaal van zo'n 400 wetenschappelijke publicaties. 
En dan zijn er nog de columns, die hij sinds de jaren tachtig wekelijks in dag- en weekbladen schreef. Wanneer we bedenken dat Van Doorn zelden verzuimde een column te schrijven en de laatste vijf jaar, tot vlak voor zijn dood, er zelfs twee per week schreef (één in Trouw en één minicolumn in HP/De Tijd), dan moet hij met elkaar zo'n 1.500 columns hebben geschreven. Inderdaad, een kolossaal oeuvre!

Niet alleen dat het oeuvre omvangrijk is, het vertoont zowel grote diversiteit, als ook opvallende continuilteit. Van Doorn hield zich met veel en ook zeer uiteenlopende onderwerpen bezig. Tegelijkertijd zijn er veel thema's, die hij in het begin van zijn carrière aan de orde stelde en die hem tientallen jaren lang bleven interesseren. Ik noemde al (militaire) organisatie, Indië/Indonesië, de verzorgingsstaat en de Nederlandse politiek. Daaraan kunnen nog worden toegevoegd: sociale ongelijkheid, beroepen en professionalisering, verzuiling, het socialisme, levensbeschouwelijk en later etnisch pluralisme en niet te vergeten beleid en de rol die de sociale wetenschappen daarbij (kunnen) spelen. Het zijn alle thema's, waaraan hij reeds in de jaren vijftig aandacht besteedde en die telkens weer terugkeren in latere geschriften, waaronder ook zijn talloze columns.

$\mathrm{Nu}$ is de vraag naar continuiteit/discontinuïteit natuurlijk van relatieve aard. Een wetenschapsbeoefenaar moet ergens beginnen en telkens wanneer hij of zij een geheel nieuw thema aansnijdt, is er 'discontinuiteit' ten opzichte van een eerder behandeld ander thema. In dit opzicht is er ook in het werk van Van Doorn op tal van punten discontinuïteit aan te wijzen. Echter, wanneer ik spreek van continuiteit in zijn werk, bedoel ik vooral dat hij vaak over periodes van vele tientallen jaren telkens weer is teruggekeerd naar thema's, die hem al eerder bezig hebben gehouden en daar vervolgens nieuwe analyses aan toevoegt. Hij is dus heel vaak 'trouw' gebleven aan eerder aan de orde gestelde thema's.

Sommige van die thema's zijn op een of andere wijze kennelijk gebaseerd op persoonlijke ervaringen, zoals het verblijf als militair in Indonesië, ervaringen met de verzuiling door het opgroeien in een katholieke 'grensstad' (Maastricht) én als directeur van een 'algemeen', niet-verzuild instituut voor sociaal-wetenschappelijk onderzoek te midden van wél verzuilde instituten. Zijn belangstelling voor economische verhoudingen en vraagstukken van arbeidsmarkt ontstond toen hij in 1960 als enige socioloog werd benoemd aan een economische faculteit, die de NEH destijds was. Ook heeft hij wel eens verteld dat zijn visies op sociale ongelijkheid mede vorm hebben gekregen door adviseurschappen in het bedrijfsleven.

Verder zijn er, zoals ik al eens eerder heb vastgesteld, ook allerlei dwarsverbindingen tussen de verschillende thema's waar Van Doorn zich mee heeft beziggehouden (zie uitvoeriger: Ellemers 1985). Bijvoor- 
beeld tussen (militaire) organisatie, macht en 'ontsporing van geweld' en later het optreden van internationale 'vredesmachten'. Er zijn ook dwarsverbindingen van organisatiesociologie naar organisatie van beroepen en professionalisering en van organisatiesociologie naar verzuiling en vragen over maatschappelijke en politieke mobilisatie en natuurlijk naar beleid. Zo zijn er nog wel meer dwarsverbindingen aan te wijzen tussen onderwerpen waar Van Doorn zich ooit mee bezig heeft gehouden - waaronder, opnieuw, ook in zijn columns.

\section{Vooral een ideeënman}

Maar is er in het werk van Van Doorn ook sprake van continuiteit in sociologische visie en opvattingen met betrekking tot eerder door hem aan de orde gestelde onderwerpen? Dit is een vraag die ik veel moeilijker vind te beantwoorden. Dat heeft mede te maken met zijn stijl van werken en de wijze waarop hij maatschappelijke verschijnselen analyseert. In mijn ogen is Van Doorn vooral een 'ideeënman'. Zijn sterke punt is dat hij aan de hand van flitsende ideeën en treffende voorbeelden, vaak met behulp van tot de verbeelding sprekende metaforen, verschijnselen weet te benoemen en te analyseren die - op dat moment - zeer verrassend en vernieuwend zijn.

Laat ik daar een voorbeeld van geven. In de jaren vijftig was Van Doorn als directeur van het ISONEVO betrokken bij onderzoek naar ziekteverzuim. Het was nog in de tijd dat men algemeen aannam dat ziekteverzuim voornamelijk een kwestie was van ziek zijn - dat is natuurlijk meestal zo, maar niet altijd. De gedachte dat ziekteverzuim ook met andere factoren dan ziekte had te maken, was toen nog allerminst gemeengoed. Behalve in ziekteverzuim was Van Doorn in verband met zijn proefschrift ook geïnteresseerd in medisch handelen in het leger. In een korte bespreking van drie boeken over respectievelijk ziektebeleving in een Twentse huisartsenpraktijk, gevechtsuitputting van Nederlandse militairen in Korea en schoolverzuim, kwam Van Doorn tot de conclusie dat medisch handelen soms een 'ventielfunctie' vervult om maatschappelijk falen te verhullen (Van Doorn 1956b). Deze analyse werd destijds als zeer verrassend gezien en er is aanvankelijk ook gretig naar verwezen. Voor zover ik weet, heeft Van Doorn in latere publicaties zijn idee over de 'ventielfunctie' van medisch handelen niet verder uitgewerkt of onderbouwd. De ideeën van verschuivingen in sociale controle en van latente functies zijn echter in zijn verdere werk duidelijk aanwezig - te beginnen met het proefschrift en in Moderne sociologie.

Van Doorns stijl van werken is voorts sterk schetsmatig. In de 'Algemene inleiding' van het ook in 1956 verschenen proefschrift, schrijft hij (1956a: 3) het volgende: 
De studie blijft grotendeels het stempel dragen van een 'frontverkenning', die zich voltrekt in een reeks van tastenderwijs gezochte compromissen tussen feiten-onderzoek en speculatieve beschouwingen. Zij is sterk hypothetisch en derhalve voorlopig, en biedt als resultaat slechts een schets, die zozeer correctie zal behoeven dat uiteindelijk wellicht een totale omwerking der gevonden gezichtpunten nodig zal blijken te zijn.

Men kan zich afvragen of veel van Van Doorns latere werk ook niet het karakter draagt van 'frontverkenningen' en 'schetsen'. Het valt in ieder geval op dat hij ook ter inleiding van latere boeken herhaaldelijk spreekt van 'schetsontwerp' (Van Doorn 1963b: 8), 'voorlopige notities' (Van Doorn 1966: ix) of 'een reeks verkenningen' (Van Doorn 2002a: 13).

Die vraag komt eigenlijk eveneens ter sprake in verschillende van de overigens zeer lovende besprekingen van zijn laatste boek, Duits socialisme. Men vindt het 'knap', 'indrukwekkend', van een 'verfrissende onbevangenheid', 'tot nadenken stemmend', maar er wordt ook gewag gemaakt van 'lacunes' en zelfs dat de vragen 'eenzijdig' waren. Natuurlijk, zelfs op de meest briljante studies valt wel wat af te dingen. Toch is het misschien tekenend dat Van Doorn in een reactie op twee besprekingen - die enkele weken voor zijn overlijden verscheen onder de titel 'De kernthese gehandhaafd' - opmerkt dat de recensenten 'zich terecht (hebben) afgevraagd of de redeneerlijn niet al te strak is getrokken' (Van Doorn 2008: 34). Anders gezegd: is ook in deze studie het betoog niet te schetsmatig?

Zeker, Duits socialisme werd onder grote tijdsdruk voltooid - toen de schrijver al wist dat hij niet lang meer had te leven. Aan de andere kant betrof het een onderwerp waar hij al jarenlang mee bezig was en dat hij in zijn eigen woorden 'al half en half had besloten te laten rusten' (Van Doorn 2007a: 12). Mijn indruk - mede gebaseerd op gesprekken en correspondentie over de voortgang van deze studie - is, dat juist deze tijdsdruk in belangrijke mate heeft bepaald hoe het boek uiteindelijk vorm heeft gekregen.

Ik herinner me trouwens verhalen hoe ook andere geschriften van Van Doorn onder tijdsdruk tot stand zijn gekomen. Dit was uiteraard helemaal het geval met de wekelijkse columns, die vaak inhaakten op zeer recente gebeurtenissen. Ik denk zelfs dat dit misschien wel het meest kenmerkende is van Van Doorns stijl van werken: aan de hand van flitsende ideeën 'frontverkenningen' verrichten en zich minder bekommeren over vragen 'of de redeneerlijn niet al te strak is getrokken'. 


\section{Continuïteit of discontinuïteit?}

Na deze opmerkingen over Van Doorns stijl van werken keer ik terug naar de vraag of er, behalve van continuilteit in termen van thema's waar hij zich mee heeft beziggehouden, ook sprake is van continuitteit in zijn sociologische visie en opvattingen. Ten dele is deze vraag in het voorgaande al beantwoord: ongeacht of hij zich bezighield met historische of contemporaine onderwerpen, ongeacht of hij 'wetenschappelijke' studies dan wel wekelijkse 'krantenstukjes' produceerde, steeds prevaleerden sociologische zienswijzen. Hij was en bleef in essentie een socioloog - al noemde hij zich later ook wel eens (overigens niet geheel ten onrechte) 'historicus', onder andere op de flap van Duits socialisme.

Moeilijker te beantwoorden is de vraag of er in zijn opvattingen over de sociologie veranderingen zijn aan te wijzen. Voor een deel is deze vraag met een volmondig 'ja' te beantwoorden. Sinds ongeveer de jaren tachtig is hij duidelijk anders gaan denken over de (maatschappelijke) rol van wetenschap en sociologie. Maar ook dan blijft de vraag of en in welke mate Van Doorn anders is gaan denken over de inhoud van de sociologie als wetenschappelijke discipline.

In interviews en ook bij andere gelegenheden heeft hij er herhaaldelijk blijk van gegeven dat hij nooit erg trouw is geweest aan één bepaald sociologisch paradigma. Dat heeft hij gemeen met veel sociologen van zijn generatie. Pas nadat Van Doorn zijn naam al had gevestigd, zouden er in Nederland min of meer duidelijke sociologische 'scholen' ontstaan, zoals de figuratiesociologie en verklarende sociologie, alhoewel deze schoolvorming ook weer niet moet worden overdreven. Uit verspreide uitlatingen blijkt dat Van Doorn nogal sceptisch stond tegenover zulke schoolvorming.

Zoals gezegd, evenals vele van zijn generatiegenoten, ging Van Doorn tamelijk 'eclectisch' te werk in de keuze van te hanteren sociologische theorieën. Hij was zeer belezen, kende en maakte gebruik van de 'klassieken' in het vak - Marx, Weber, Durkheim, Simmel, Michels, aanvankelijk ook Mannheim -, maar ook veelvuldig van de modernere 'mainstream' sociologie - en dat was in de jaren vijftig en zestig vooral Amerikaanse sociologie. Daarnaast vertoont zijn werk invloeden van klassieke denkers als Hobbes, Spengler, Nietzsche en later ook Isaiah Berlin - en niet te vergeten van bellettrie, die hij eveneens in grote hoeveelheden consumeerde. Tot kort voor zijn dood kon hij in gesprekken en in brieven enthousiast verhalen over nieuwe romans en biografieën die hij had gelezen en die ongetwijfeld mede een rol in zijn denken hebben gespeeld.

Van Moderne sociologie - toch wel een chef d'oeuvre; ook van Van Doorn - is wel eens beweerd dat het erg 'Amerikaans' en zelfs 'parsoniaans' zou zijn. Zonder de discussies hierover weer op te rakelen, wil ik hier 
nogmaals vaststellen dat het boek een goed overzicht bood van de stand van zaken van de sociologie aan het eind van de jaren vijftig. En die was in die tijd - en is in bepaalde opzichten nog steeds - overwegend Amerikaans; zowel theoretisch als empirisch-methodologisch. Bovendien - en dat is vaak vergeten - bood het boek óók een overzicht van de stand van zaken van de Nederlandse sociologie anno 1959 - hoe beperkt die toen nog was.

De vraag die hier verder aan de orde is, luidt of in de herziene uitgave van 1976 sprake is van nieuwe of gewijzigde visies op de sociologie. Allereerst moet dan worden vastgesteld dat Van Doorn in 1985 in een interview heeft opgemerkt: 'Nou, die systematische opzet van het boekje, daar zou ik nooit opgekomen zijn; daar had ik noch het geduld, noch het vermogen toe gehad' (Nijhoff en Pels 1985: 5). Anders gezegd: de systematiek van Moderne sociologie moet grotendeels op het conto van Lammers worden geschreven. In het 'Voorwoord bij de herziene dertiende druk' schrijven de auteurs dat een 'volledige herziening' een 'onmogelijke opgave' was en dat wat nu aangeboden wordt 'het best mogelijke' is: 'een in grote trekken aangepaste, gedeeltelijk gestroomlijnde en in onderdelen hernieuwde tekst, met volledig behoud van de aanvankelijk gekozen opzet' (Van Doorn en Lammers 1976: 13-14). Slechts in 'aanvullende commentaren' bij afzonderlijke hoofdstukken wordt ingegaan op inmiddels nieuwere ontwikkelingen. Deze nieuwe inzichten worden echter nauwelijks verwerkt in de herziene uitgave. Dat is misschien opvallend, omdat Van Doorn in de jaren zeventig belangstelling heeft getoond voor het symbolisch interactionisme en ook Lammers heeft gepleit voor meer 'polyparadigmatische' opleidingen in de sociologie. Centraal blijven sociale en culturele systemen en functionele relaties en tot de meest geciteerde auteurs blijven Weber, Durkheim, Merton en Parsons behoren. Ook in ander en later werk van beide auteurs blijken de inzichten van deze en andere, inmiddels als 'klassiek' te bestempelen sociologen een belangrijke inspiratiebron te zijn gebleven. Samenvattend: uit de herziene druk van Moderne sociologie blijkt een grote mate van continuïteit.

Zijn er dan helemaal geen wijzigingen in de sociologische zienswijzen van Van Doorn aan te wijzen? Hier wil ik allereerst op weliswaar betrekkelijke, maar niettemin significante veranderingen van inzichten wijzen. Ik geef daar twee voorbeelden van, die opnieuw iets verraden over zijn stijl van werken.

Van Doorns eerste boek, De proletarische achterhoede (1954), was een frontale aanval op de twee jaar eerder verschenen dissertatie van J. Haveman, De ongeschoolde arbeider, die veel aandacht trok en door verschillende vakgenoten zeer werd geprezen. De gedachte van Haveman was dat er een soort subcultuur bestond van ongeschoolden die in achter- 
buurten wonen. Van Doorn had hier fundamentele kritiek op, zowel van theoretische, als van methodologische aard. Deze kritiek is destijds vrij algemeen aanvaard. Pas dertig jaar later heeft Bovenkerk zich opnieuw in de kwestie verdiept en onder andere ook Van Doorn geïnterviewd. In

dit interview geeft deze vrij onomwonden toe dat bij nader inzien zijn kritiek op de wijze waarop Haveman het begrip subcultuur hanteert niet helemaal terecht is: 'Tja, zo zou je het ook kunnen zien' (Bovenkerk 1984: 9).

In 1968 raakte Van Doorn gefascineerd door het verschijnsel maatschappelijke mobilisatie, een fascinatie die voortkwam uit wat hij later noemde een 'mini-revolutie' in zijn denken, die hem 'een onmiskenbaar “heureka”-gevoel' gaf (Van Doorn 1973: 40).

Door in plaats van te blijven ronddraaien in de conceptie van organisatie als een continu en stabiliserend, zekerheid garanderend systeem nu eens als uitgangspunt te nemen de campagne in de zin van een tijdelijk, dynamiserend en risicodragend proces bleken plotseling allerlei details 'op hun plaats te vallen'.

In verschillende geschriften werkte hij deze visie uit, onder andere in een in 1969 gepubliceerd artikel, getiteld 'De voortgezette revolutie: China en de ijzeren wet der oligarchisering', dat nogal opzien baarde. De teneur van het artikel is dat de politieke mobilisatie van Mao de fout van het stalinisme - vervreemding tussen partij en massa - heeft vermeden en daarmee aan de tendentie tot oligarchisering heeft weten te ontsnappen (Van Doorn 1969). Daar is twee jaar later ernstige kritiek op geleverd door Bart Tromp (1971). In zijn reactie schreef Van Doorn dat hij dankbaar is voor de belangstelling en kritiek, maar niet in zijn mening is geschokt (Van Doorn 1971: 463). Vervolgens is een iets uitvoeriger versie van het artikel, waarin de kritiek van Tromp maar ten dele is verwerkt, twee jaar later herdrukt in Van Doorns bundel Met man en macht (1973). Bij het overlijden van Tromp in 2007 schreef Van Doorn (2007b) in zijn column 'Afscheid van Bart Tromp' het volgende:

Polemiek was zijn lust en zijn leven. Ik heb het ondervonden toen ik in 1969 een nogal topzwaar sociologisch artikel publiceerde over de zogeheten Culturele Revolutie in China en daarbij een poging deed de brute interventie van Mao Zedong te interpreteren als een doorbreking van de verstarring van het Chinese communisme. Tromp ging voluit in de aanval. (...) En hoewel ik in de dupliek moedig stand hield, bekroop mij tegelijkertijd het gevoel dat Tromp, met zijn persoonlijke kennis van het politieke bedrijf, wel eens gelijk kon hebben. 
Ik geef deze twee voorbeelden om te illustreren dat Van Doorn vaak gegrepen is door een bepaalde idee en daar een fascinerende analyse op baseert, om later - inderdaad, soms tientallen jaren later - te erkennen dat het allemaal genuanceerder was of zelfs toe te geven dat de hele analyse niet deugde. Opnieuw: een man van flitsende ideeën, die tegelijkertijd bereid is zijn analyses te herzien of terug te nemen. Dit is mijns inziens óók een kenmerk van de continuïteit én discontinuïteit in het werk van Van Doorn.

\section{Echte omslagen in het denken van Van Doorn}

Toch zijn er wel degelijk bepaalde en vrij duidelijk te identificeren 'omslagen' in het denken van Van Doorn aan te wijzen. Daarover bestaan echter ook zeer valse clichés. Zo is gesteld dat hij in de eerste helft van zijn leven een theoretisch bouwwerk optrok en zich pas daarna verdiepte in historische onderwerpen (Vlasblom 2008). Dit is pertinente onzin. Een van zijn allereerste artikelen (1947) handelde over de geschiedenis van Maastricht. Het tweede deel van zijn dissertatie (1956) begint met een historische analyse van de krijgsorganisatie van de Germaanse volkeren en loopt via het ridderwezen en de legerhervormingen van Maurits naar de huidige tijd.

De echte omslag in het denken van Van Doorn voltrok zich in de periode rond zijn vertrek van de universiteit en hij gaf daar duidelijk blijk van in zijn afscheidsrede, die hij vervolgens uitwerkte in de een jaar later verschenen bundel opstellen Rede en macht. Een inleiding tot beleidswetenschappelijk inzicht (Van Doorn 1988). Het is een kritische evaluatie van de Verlichting en de overwegend universalistische en positivistische oriëntatie in het westerse denken, die heeft geleid tot een technologisch kennisideaal en een streven naar rationele maatschappelijke beheersing, waarin interventiewetenschappen, zoals bedrijfskunde en bestuurskunde, een steeds grotere rol spelen. Aan dit alles is hij sinds de jaren tachtig steeds meer gaan twijfelen, zoals blijkt uit Rede en macht en uit latere geschriften.

Terloops merk ik op dat het pikant is dat op dezelfde dag dat hij zijn afscheidsrede uitsprak, hem ter gelegenheid van dit afscheid een bundel werd aangeboden waar de 'Rotterdamse formule' nog eens uitvoerig ter sprake kwam en werd geprezen (Berting et al. 1987). Over een 'dwarse persoon' gesproken.

Toen hij de 'Rotterdamse formule' in het begin van de jaren zestig presenteerde, pleitte hij nog voor een sociaal-politiek relevante sociologiebeoefening. In zijn programmatische stellingname 'Sociologie als opleiding' van 1963 schreef hij: 'Niet de keuze tussen onthouding en engagement is aan de orde, maar die tussen meer of minder geslaagd 
engagement' (Van Doorn 1963a: 189). Eerder, in 'Sociologie als beroep', had hij al gesteld: '(...) de sociologie (zal) haar beoefenaren moeten stimuleren tot het innemen van een standpunt, het doortrekken van analyse tot advies, van advies tot beleid' (Van Doorn 1961: 111).

Een kleine veertig jaar na deze zeer uitgesproken stellingname over de professionele rol van de socioloog - deze keer ironisch genoeg ter gelegenheid van het 35-jarig bestaan van de Rotterdamse Faculteit der Sociale Wetenschappen, die 'wetenschappelijk gefundeerde beleidsgerichte opleidingen' verzorgt - gaat Van Doorn nog veel verder dan in zijn afscheidsrede en in Rede en macht. Hij schrijft dan (2000: 38-39) als volgt:

De versplintering van de maatschappelijke orde schiep een reeks van nieuwe problemen die met de klassieke sociaal-wetenschappelijke theorieën moeilijk zijn te interpreteren. Het maakbaarheidsgeloof in grote stijl, dat voorheen als motor van sociale wetenschapstoepassing had gefungeerd, maakte plaats voor twijfel en verwarring, en voor de neiging muddling through te verkiezen boven grootse visies en grootschalige maatschappelijke projecten.

In de volgende alinea stelt hij bij wijze van afsluiting:

Om de metafoor nog één keer van stal te halen: de driehoek (die wetenschap, maatschappij en beleid verbindt) waarbinnen de sociale wetenschappen zich thans bevinden, is vergeleken bij die van een eeuw geleden drastisch gekrompen: de actieradius is naar alle kanten ingekort. Het onderzoek gaat door, het beleid blijft opdrachten verstrekken en de gegevens stromen toe, maar de grote greep is verloren gegaan. De sociale wetenschappen kunnen nu eenmaal niet meer allure hebben dan de maatschappij waarin ze werkzaam zijn.

De breuk in het denken van Van Doorn blijkt verschillende componenten te bevatten: twijfels over de rol van de rede en relativering van de rationaliteit; vragen of de maatschappelijke orde niet zodanig is veranderd dat de sociale wetenschappen er steeds minder greep op hebben; en ten slotte en in verband daarmee vragen over de 'maakbaarheid' van de maatschappij en de relevantie en veranderde rol van de 'interventiewetenschappen'. Het zijn allemaal kolossale vragen, die ieder omvangrijke, honderden pagina's tellende studies rechtvaardigen. Het kan niet de bedoeling zijn in deze beknopte schets van het leven en werk van de overleden socioloog hier een uitwerking van te presenteren. Bovendien besteedt Romke van der Veen in deze bundel ook nog afzonderlijke aandacht aan Van Doorns opvattingen over beleidssociologie en de "professionele rol' van de socioloog. Hier volsta ik slechts met de vaststelling 
- deels aan de hand van citaten van Van Doorn zelf - dat er behalve een grote mate van continuilteit ook sprake is geweest van wezenlijke veranderingen in het denken van Van Doorn over wetenschap en maatschappij.

Wel wil ik hierbij opmerken dat opvalt dat ook in de sinds de jaren negentig verschenen studies van Van Doorn in boekvorm, zoals De laatste eeuw van Indië (1994), Indische lessen (1995), Gevangen in de tijd. Over generaties en hun geschiedenis (2002a) en Duits socialisme (2007a), weinig tot niets blijkt van een nieuwe of andere visie op de sociologie als discipline. Toegegeven, het betreft alle onderwerpen die zich in het verleden hebben afgespeeld. Maar het zijn wel stuk voor stuk analyses, die gebaseerd zijn op 'conventionele' sociologische concepten en inzichten. Zij openen weliswaar nieuwe vergezichten en leggen deels onvermoede verbanden. Ze worden echter verricht aan de hand van al veel langer bestaande sociologische inzichten en berusten niet op een geheel nieuwe sociologische visie.

\section{Raadselachtige elementen}

Er blijven toch raadselachtige elementen in de omslagen in het denken van Van Doorn. In latere geschriften - sinds ongeveer Rede en macht en ook in columns en interviews - vroeg hij meer aandacht voor massaverschijnselen en voor schrijvers die zich hier mee bezighielden, als Le Bon, Sorel, Freud en anderen. In zekere zin kan men zeggen dat dit past in zijn eerdere belangstelling voor institutionalisering, de-institutionalisering en re-institutionalisering en voor mobilisatie en demobilisatie. In het in 2000 verschenen artikel, waaruit ik eerder citeerde, schreef hij (Van Doorn 2000: 34-35) het volgende:

Oude en destijds goed herkenbare sociale categorieën zijn versplinterd. Standen en klassen zijn uiteengevallen, door de sociologie al opgemerkt toen men naar beroepsgroep begon te onderscheiden, een indeling die inmiddels ook nog maar beperkte waarde heeft. Allerlei andere groepsonderscheidingen zijn diffuus geworden: verschillen tussen de seksen, tussen leeftijdsklassen, tussen werkenden en niet-werkenden, tussen stedelingen en plattelanders, tussen legale en illegale inwoners.

En enkele alinea's later:

Ten slotte is er de onmiskenbare subjectiveringstendentie in het maatschappelijk verkeer, op allerlei wijzen te karakteriseren: als een emotiecultuur en een klaagcultuur, ook in de politiek door- 
gedrongen waar van 'emotiedemocratie' wordt gesproken en in het rechtsbewustzijn dat tot toenemend claimgedrag aanleiding geeft. De betekenis van personen en van incidenten wint het vaak van doctrines en structuren. De publieke opinie is richtinggevend en beeldvorming een argument geworden.

In een in 2002 verschenen artikel 'Democratie in de overgang' werkte Van Doorn sommige van deze gezichtspunten nader uit met betrekking tot het politieke bestel. In een zeer genuanceerde uiteenzetting suggereert hij tot slot dat er naast een 'personalisering' van het gezag, toch ook nog een andere weg openstaat. Hierbij 'valt te denken aan formele demarcatie en waar mogelijk hiërarchisering van de belangrijkste subsystemen waardoor afstemmingsproblemen efficiënter dan momenteel kunnen worden afgehandeld' (Van Doorn 2002b: 54).

Het raadselachtige vind ik dat Van Doorn hier - na een omstandige analyse van de malaise in de politiek en de ineffectiviteit van het overheidshandelen - toch weer 'Contouren van een nieuw beleid' schetst en spreekt over 'De dominantie van doelmatigheid', zoals de titels van twee van de paragrafen van zijn opstel luiden. Dus toch 'maakbaarheid' en 'interventie' en organisatie als panacee voor politieke malaise? Het lijkt wel of Van Doorn hierover blijft aarzelen.

Haast nog raadselachtiger vind ik het volgende. Uit latere geschriften en uitlatingen blijkt dat hij allerlei ontwikkelingen in het politieke en publieke bestel steeds negatiever is gaan beoordelen. Zo sprak hij in interviews, die in het jaar voor zijn overlijden verschenen, zeer laatdunkend over bijvoorbeeld Fortuyn, Wilders, 'de vloek van het populisme' en de 'gemakzuchtige media'. ${ }^{3}$ Goed beschouwd, is dit opmerkelijk voor een socioloog die zich bezighield met institutionalisering en de-institutionalisering en met sociale mobilisatie, later aandacht vroeg voor irrationeel gedrag en al jarenlang sprak en schreef over 'malaise in de politiek'. Had Van Doorn, behalve in afkeurende bewoordingen, juist in analytische zin niet meer kunnen zeggen over deze recente ontwikkelingen, bijvoorbeeld op basis van eerder bepleite massapsychologische inzichten? Had hij zijn analyses, behalve in termen van structurele en institutionele factoren, ook niet moeten uitbreiden naar 'het culturele klimaat van het alledaagse postmodernisme', dat hij al eerder terloops noemde (Van Doorn 2000: 35), maar niet verder uitwerkte? Het zijn natuurlijk enorme vragen die makkelijker zijn te stellen dan te beantwoorden. Maar het blijft enigszins raadselachtig dat Van Doorn daar nooit verder op in is gegaan. Of bleef hij van mening dat de versplintering van de maatschappelijke orde vanuit de sociale wetenschappen eenvoudig niet valt te interpreteren?

Van de betrekkelijkheid van de continuïteit of discontinuïteit in 
het denken van Van Doorn, wil ik hier tot slot nog één voorbeeld noemen. Over etnische verhoudingen publiceerde hij in 1985 een opstel, 'Het miskende pluralisme: Een herformulering van het minderhedenvraagstuk', dat in omgewerkte vorm als 'Etniciteit en pluralisme' is opgenomen in Rede en macht (Van Doorn 1988: 51-78). In beide versies wordt genuanceerd gesproken over de kenmerken en problemen van de multiculturele samenleving en worden vergelijkingen getrokken met de verzuiling. Uit latere uitlatingen - met name in zijn columns en in interviews - krijgt men de indruk dat hij hierover een veel negatievere mening heeft ontwikkeld. Zo merkt hij in een interview in 2001 (vóór 11 september) op: 'De samenleving heeft geen middelen genoeg om de integratie te bewerkstelligen. De achterstand van sommige groepen is veel te groot. (...) Je kunt (...) de vraag stellen of de islam een godsdienst is die zich laat integreren' (Jansen en Van der Veen 2001: 8). Weer later nam hij het toch weer op voor de multiculturele samenleving, bepleitte een herstel van tolerantie tussen autochtonen en moslims en hekelde in scherpe bewoordingen het optreden van 'islamofoben'. ${ }^{4}$ Bleef hij over deze kwesties gewoon genuanceerd en tolerant denken of moeten wij in zijn (schijnbaar?) wisselende opvattingen vooral 'dwarse' uitingen zien van de 'eeuwige non-conformist', die steeds stelling nam tegen op dat moment geldende 'politiek correcte' denkbeelden?

Op de vaak gestelde vraag of Van Doorn in zijn denken 'conservatiever' is geworden, ga ik hier niet in. In het licht van het voorgaande weet ik het antwoord hierop niet goed en ik ben zelfs niet zeker of Van Doorn zelf dat wel had. Hij koketteerde er soms mee, maar was dat toch niet mede een kenmerk van zijn intellectuele dwarsheid?

\section{Bezeten man en non-conformist}

Wanneer we het geheel overzien, blijkt dat Van Doorn op een zeer breed terrein actief is geweest en gekenmerkt werd door een enorme werkkracht. Niet alleen als auteur van vele boeken, artikelen en columns, maar ook als redacteur van tijdschriften en bij het samenstellen van talloze boeken was hij buitengewoon actief. In het voorgaande zijn herhaaldelijk termen gebruikt als 'drijvende kracht', 'gangmaker', 'opinieleider', 'uitdagend' en 'dwars'. Hij was een bezeten man die grote werkkracht paarde aan een sterk analytisch vermogen, die bovenal zijn hele leven uiteindelijk een non-conformist is gebleven.

Hij was altijd bezig met 'projecten' en 'clubjes' en ik heb zelden gehoord dat hij niet iets 'onder handen' had. Zoals hij in verschillende interviews sinds de jaren tachtig herhaaldelijk heeft gezegd: 'Voor alle plannen die ik heb, heb ik minstens nog duizend jaar nodig.' Wanneer ik dit afmeet aan de vele brieven die ik met hem heb gewisseld, moet 
hij ook een omvangrijke correspondentie hebben gevoerd. Een kenmerk daarvan was dat hij meestal onmiddellijk reageerde met uitvoerige, vaak meerdere pagina's tellende exposés.

Het is haast onbegrijpelijk hoe hij naast vele en uiteenlopende organisatorische besognes - inclusief lobbyactiviteiten in academische en andere circuits -, tijd en gelegenheid vond om een zeer omvangrijk oeuvre tot stand te brengen. Ja, hij formuleerde makkelijk en trefzeker en beschikte over een grote mate van discipline en een ijzersterk geheugen. Hij las ook ontzettend veel (ver buiten het vakgebied) en hield een kolossaal archief bij, zodat hij altijd over de juiste citaten en treffende motto's beschikte (haast ieder van zijn geschriften had een passend motto). Kortom, hij was een bezeten man.

Ondanks zijn vele en veelsoortige activiteiten en zijn bezetenheid wekte hij de indruk altijd alle tijd te hebben. Zijn bezetenheid en nonconformisme werden verhuld door een kalm en beheerst optreden en een zekere vormelijkheid en conservatisme in uiterlijk. De bezetenheid werd ook in toom gehouden door een enorme discipline. Hij stelde zich voortdurend duidelijke doelen en deadlines en werkte meestal aan de hand van schema's. Dat hij de studie over het Duits socialisme aanvankelijk niet kon voltooien, heeft er misschien mee te maken dat er voor het eerst in zijn leven geen duidelijke deadline was. Het boek kreeg pas zijn definitieve vorm toen de dood hem op de hielen zat. Ook hierbij werkte hij wederom met een schema, dat de basis vormde van de in het voorlaatste jaar van zijn leven geschreven tekst.

Alhoewel hij later twijfels koesterde over rationaliteit, maakte hij - op mij althans - de indruk van een uiterst rationele, cerebraal functionerende man. Hij kon veel tijd steken in allerlei 'projecten', clubjes en persoonlijke contacten, maar wanneer het onderwerp of de persoon hem niet langer interesseerde, kon hij het onderwerp of de relatie ook abrupt afsluiten. Van Doorn was schijnbaar zeer beheerst en afstandelijk en toonde weinig emotie. Maar achter deze afstandelijkheid lagen natuurlijk wel degelijk sterke emoties.

\section{Noten}

1. Met dank aan de redactie van het tijdschrift Sociologie en uitgeverij Boom voor toestemming tot herdruk van dit artikel, dat in 2008 in genoemd tijdschrift verscheen (jrg. 4, no. 4, pp. 396-411). Bij die gelegenheid bedankte de auteur de heren H. Daalder, H. van Goor, C.J. Lammers, P. Mascini en redacteuren van Sociologie voor commentaar op eerdere versies.

2. Het is onvermijdelijk dat ik hier en daar teruggrijp op een eerder artikel dat ik over Van Doorn schreef (Ellemers 1985), alhoewel ik heb gepoogd hier ook andere, niet eerder behandelde, gezichtspunten te ontwikkelen. Om de noten en literatuurverwijzingen binnen proporties te houden, zijn er alleen maar verwij- 
zingen naar direct in de tekst genoemde publicaties. Voor een volledig overzicht van de wetenschappelijke publicaties van Van Doorn tot 1985, zie Terlouw (1985).

3. Interviews door Hans Wansink in De Volkskrant (7 juli 2007) en door Hugo Camps in Elsevier (6 oktober 2007).

4. Dit komt bijvoorbeeld naar voren in columns in Trouw in de eerste maanden van 2008 en in zekere zin ook in de in de vorige noot genoemde interviews.

\section{Geraadpleegde literatuur}

Berting, J., J. Breman en P.B. Lehning (red.) (1987), Mensen, macht en maatschappij. Een bundel sociaal-wetenschappelijke opstellen, Amsterdam/Meppel: Boom.

Bovenkerk, F. (1984), 'Haveman en Van Doorn over de ongeschoolde arbeider', Sociodrome 1: 3-9.

Doorn, J.A.A. van (1947), 'De economische geest te Maastricht: Een sociografische studie', Mensch en maatschappij 22: 1-12, 74-96.

Doorn, J.A.A. van (1954), De proletarische achterhoede: Een sociologische critiek, Meppel: Boom.

Doorn, J.A.A. van (1956a), Een sociologische benadering van het organisatieverschijnsel, Leiden: Stenfert Kroese.

Doorn, J.A.A. van (1956b), 'Het medisch ventiel voor maatschappelijk falen: Over functieveranderingen in de gezondheidszorg', Sociologische gids 3: 152-157 (herdrukt in Sociologische gids 51 (2004): 346-352).

Doorn, J.A.A. van (1961), 'Sociologie als beroep', Sociologische gids 8: 98-113.

Doorn, J.A.A. van (1963a), 'Sociologie als opleiding', Sociologische gids 10: 183-196.

Doorn, J.A.A. van (1963b), Sociale ongelijkheid en sociaal beleid. Arbeiders en employés in onderneming en maatschappij, Utrecht: Bijleveld.

Doorn, J.A.A. van (1966), Organisatie en maatschappij: Sociologische opstellen, Leiden: Stenfert Kroese.

Doorn, J.A.A. van (1969), 'De voortgezette revolutie: China en de ijzeren wet der oligarchisering', Sociologische gids 16: 155-178.

Doorn, J.A.A. van (1971), 'Tromp over Robert Michels: Een repliek', Sociologische gids 18: 458-463.

Doorn, J.A.A. van (1973), Met man en macht: Sociologische studies over maatschappelijke mobilisatie, Meppel: Boom.

Doorn, J.A.A. van (1985), 'Het miskende pluralisme: Een herformulering van het minderhedenvraagstuk', in: G.G. Cain, J. Sperna Weiland en J.H.P. Paelinck, Etnische minderheden. Wetenschap en beleid, Amsterdam: Boom, p. 67-96.

Doorn, J.A.A. van (1987), Relativering van rationaliteit: Over de grenzen van technisch denken en technocratische beheersing, 's-Gravenhage: VUGA.

Doorn, J.A.A. van (1988), Rede en macht: Een inleiding tot beleidswetenschappelijk inzicht, 's-Gravenhage: VUGA. 
Doorn, J.A.A. van (1994), De laatste eeuw van Indië. Ontwikkeling en ondergang van een koloniaal project, Amsterdam: Bert Bakker.

Doorn, J.A.A. van (1995), Indische lessen. Nederland en de koloniale ervaring, Amsterdam: Bert Bakker.

Doorn, J.A.A. van (2000), 'Sociale wetenschappen en de weerbarstige werkelijkheid', in: P.B. Lehning (red.), De beleidsagenda 2ooo. Strijdpunten op het breukvlak van twee eeuwen, Bussum: Coutinho, p. 24-41.

Doorn, J.A.A. van (2002a), Gevangen in de tijd: Over generaties en hun geschiedenis, Amsterdam: Boom.

Doorn, J.A.A. van (2002b), 'Democratie in de overgang: Van collectieve beheersing naar geordende vrijheid', in: P.G.C. van Schie (red.), Het democratisch tekort. Interpretaties en remedies, Den Haag: Teldersstichting, p. 7-55.

Doorn, J.A.A. van (2007a), Duits socialisme. Het falen van de sociaal-democratie en de triomf van het nationaal-socialisme, Amsterdam: Mets \& Schilt.

Doorn, J.A.A. van (2007b), 'Afscheid van Bart Tromp', Trouw, 23 juni 2007.

Doorn, J.A.A. van (2008), 'De kernthese gehandhaafd', Socialisme en Democratie 65: 34-35.

Doorn, J.A.A. van en W.J. Hendrix (1970), Ontsporing van geweld. Over het Nederlands/Indisch/Indonesisch conflict, Rotterdam: Universitaire Pers.

Doorn, J.A.A. van en C.J. Lammers (1976), Moderne sociologie. Een systematische inleiding, Utrecht/Antwerpen: Het Spectrum (13de, geheel herziene uitgave; eerste druk 1959).

Ellemers, J.E. (1985), 'J.A.A. van Doorn en zijn plaats in de Nederlandse sociologie', in: De man en zijn werk. De bijdrage van J.A.A. van Doorn aan de beoefening van de sociologie in Nederland, Rotterdamse Rapportenreeks Sociale Wetenschappen nr. 1, Rotterdam: Erasmus Universiteit, p. vii-xxxix.

Haveman, J. (1952), De ongeschoolde arbeider. Een sociologische analyse, Assen: Van Gorcum.

Jansen, H. en R. van der Veen (2001), 'J.A.A. van Doorn. Twijfelen aan de sociologie', Facta 9 (7): 4-8.

Nijhoff, P. en D. Pels (1985), 'Van Doorn en Lammers over "Van Doorn en Lammers", Sociodrome 11 (3): 2-8.

Terlouw, C.P. (1985), 'Bibliografie van J.A.A. van Doorn', in: De man en zijn werk. De bijdrage van J.A.A. van Doorn aan de beoefening van de sociologie in Nederland, Rotterdamse Rapportenreeks Sociale Wetenschappen nr. 1, Rotterdam: Erasmus Universiteit, p. 1-74.

Tromp, B. (1971), 'China's revolutie en Michels ijzeren wet: Een kritiek', Sociologische gids 18: 444-457.

Vlasblom, D. (2008), 'J.A.A. van Doorn 1925-2008: Een leven lang dwars', NRC Handelsblad, 17-18 mei 2008. 



\section{Deel II}

Socioloog of historicus? 



\section{Van Doorns werk \\ Van verkeerd gesystematiseerde sociologie naar
meer gedegen geschiedwetenschap?}

Wout Ultee

De stelling dat Van Doorn socioloog was en historicus werd, gaat uit van verschillen tussen sociologie en geschiedwetenschap. Hoe groot zijn die wat betreft hun vragen, theorieën en onderzoeksmethoden? Werden niet alleen Van Doorns vragen historisch, maar ook zijn theorieën en methoden? Hoeveel droeg Van Doorn trouwens bij aan de vragen, theorieën en methoden van de sociologie? En van de geschiedenis? Deze vraagtekens zijn ingegeven door de stelling van Popper (1972) dat een wetenschap, ook de sociologie, met vragen begint, deze voorlopig beantwoordt met theorieën, en die dan op de proef stelt met passende methoden.

De vragen, theorieën en onderzoeksmethoden van een wetenschap worden beredeneerd in leerboeken. Van Doorn schreef, met Lammers, Moderne sociologie. Systematiek en analyse (1959). Later nam hij er afstand van (De Rijk 1986). Een nieuw leerboek sociologie kwam er niet. Van Doorns analyses waren ondertussen minder systematisch, meer fragmentarisch, geworden. Dat stoorde wel eens. Maar filosofen vertrouwen 'gedachten' aan het papier toe en in de schone letteren zijn 'fragmenten' en 'ideeën' erkende stijlvormen. Sociologen hoeven niet steeds het formaat van hun tijdschriften te volgen.

Onderhavig stuk over sociologie, geschiedenis en Van Doorn heeft (eveneens) een ongewone vorm. Wegens de hierboven omschreven meerledige vraag kan het betoog te veel kanten op gaan. Het blijft op koers, omdat een brede beginvraag wordt aangescherpt, aangegeven door kopjes met telkens de woorden vragen, theorieën of onderzoeksmethoden. En het lange eindantwoord komt sneller in zicht met de volgende voorproefjes. Van Doorn kwam er, om te beginnen, zelden aan toe systematisch data te verzamelen en te analyseren. Tevens bleef, ondanks de algemene en theoretische bedoelingen van het begrip 'systeem', Van Doorns 
systeemfunctionalisme arm aan uitspraken. Van Doorn liet verder, door een geringe aandacht voor beschrijvingsvragen, enkele onvoldragen verklaringsvragen na aan nieuwe generaties sociologen. De toegift komt erop neer dat Van Doorn (2009) het 'Herfsttij der democratie' aankondigde zonder hervormingen voor te stellen die het tij keren.

\section{In hoeverre verschillen geschiedwetenschap en sociologie?}

Godsdienstwetenschap en natuurkunde hadden de (cultuur)geschiedenis ondergraven. Andere systematische wetenschappen, zoals de sociologie, holden de geschiedwetenschap nog meer uit. Aldus Van Doorn (1961). Zijn voorkeur ging destijds uit naar systematiek.

Van Doorn sprak over geschiedwetenschap en sociologie als afzonderlijke opleidingen aan universiteiten. Maar zijn sociologen alleen maar systematischer dan historici of doen ze wat anders? Volgens Popper (1957) hanteren zowel sociologen als historici een schema dat bestaat uit 1) een afleidingsstreep met eronder 2) een explanandum en erboven 3) algemene beginselen en 4) aanvangsvoorwaarden. Wel zouden historici ware voorwaarden zoeken en sociologen beginselen toetsen. De auteur dezes, die geregeld geschiedenis leest, beaamt dat historici en sociologen hetzelfde 'hypothetisch-deductieve model' op die uiteenlopende manieren toepassen. Volgens hem zijn hun explananda wel meer op elkaar gaan lijken. Ze betreffen sowieso samenlevingen. Sociologen verklaren niet langer enkel kenmerken van Nederland nu, ze bepalen ook trends. Hedendaagse historici maken zich minder druk over grenzen van tijdvakken dan hun voorgangers. Ze ontleden ook vaker maatschappelijke veranderingen, hoewel de geschetste ontwikkelingen niet altijd tot het heden reiken. Dat historici nauwelijks algemene beginselen toetsen is trouwens één ding, ze schrijven ze zo zelden uit.

\section{Vragen in geschiedwetenschap en sociologie}

Bevindingen uit de geschiedwetenschap leren sociologen dat ze soms vragen verkeerd in het vat gieten. Zo is de vraag niet: waarom is na zoveel jaren links regeren de ongelijkheid nog altijd groot? De terechte vraag luidt: waarom verminderden ongelijkheden bij de overgang van akkerbouw naar industrie? Zie Lenski (1966), die historische gegevens gebruikte om sociologische vragen toe te spitsen. Leerboeken (Thurlings 1977; Laeyendecker 1981; Van Hoof en Ruijsseveldt 1996) beweren dat de sociologie drie hoofdvragen heeft. Dat van Ultee, Arts en Flap (1992) omschrijft ze als ongelijkheid, cohesie en rationalisering. Kunnen hedendaagse studenten geschiedenis zoiets oplepelen? Maar soms heb- 
ben historici hun vragen niet recht in het vizier. Volgens Huizinga (1929) leed (toen) de Nederlandse geschiedwetenschap aan het euvel van een onvoldoende formulering van haar vragen.

\section{Theorieën in geschiedwetenschap en sociologie}

Huizinga was een historicus met theoretische aanspraken. Volgens Herfsttij der Middeleeuwen (1919) smacht elke tijd naar een mooiere wereld. Iedere tijd ziet ook drie paden naar dit doel wijzen. Het eerste spoor leidt regelrecht de wereld uit. Door het aardse te verzaken bereikt een mens 'aan de overkant' verlossing. Het tweede pad wijst naar verbetering en vervolmaking van de wereld, er leeft een vaste wil om de wereld zelf beter en gelukkiger te maken. De droom is de derde weg, 'het ontvlieden van de werkelijkheid in een schone schijn'. Deze 'tussenweg' kozen Bourgondië en de Nederlanden in de veertiende en vijftiende eeuw. Het christendom in het vroegmiddeleeuwse Europa had het eerstgenoemde pad betreden. Italië sloeg in de vijftiende eeuw, met de Renaissance, de als tweede genoemde weg in, voordat enig ander Europees land dat deed. Toen Frankrijk in de achttiende eeuw als eerste met de Verlichting in die richting doorging, toonde het nog meer 'vertrouwen in de kracht van grote daden'.

De als rechtshistoricus begonnen en als socioloog gestorven Weber (1920) ging verder dan deze opsomming van geesteshoudingen. Weber maakte een opklimmende reeks door de mate van activisme in wereldbeelden te omschrijven: wereldontkenning kenmerkt het hindoeïsme, aanpassing aan de omgeving het confucianisme, levensaanvaarding het katholicisme, rentmeesterschap van de aarde het protestantisme. Het wereldbeeld van Webers tijd was - en van de tegenwoordige tijd is onderwerping van en heerschappij over de natuur.

Dit rijtje bracht Weber onder in één uitspraak. Volgens hem sorteren zonder een activistisch wereldbeeld de economische rechten waarover rechtsgeleerden het hebben - zoals de vrijheid van handel en van beroep - weinig effect. Mensen met meer daadkracht benutten die vrijheden sterker, wat leidt tot een voor velen hogere levensstandaard. Weber verklaarde zo dat rond 1900 West-Europa per inwoner meer goederen voortbracht dan China en India.

Webers 'wereldbeeldenhypothese' vormt een alternatief voor een uitspraak van Smith, de grondlegger van de wetenschap die eens 'politieke economie' heette. Zijn nalatenschap aan die wetenschap omvat de stelling dat in een staat die ondernemers vrijlaat, de welvaart stijgt. Tegenwoordig beperkt deze wetenschap, de economie, zich niet tot de vraag hoe goedkoop voor de markt gemaakte goederen als spelden zijn. Van den Doel (1975) leidt in een leerboek, uit het beginsel dat mensen ratio- 
neel handelen, de stelling af dat bepaalde goederen (straks te omschrijven als collectieve goederen) alleen door dwang van overheden optimaal worden voortgebracht (en juist ondermaats door vrije markten). Met deze 'nieuwe politieke economie' beantwoordt de socioloog De Swaan (1988), voorbijgaand aan de wereldbeeldenhypothese, de vraag waarom plaatselijke overheden rond 1900 in de grote steden van staten als Engeland en Frankrijk het net van riolen en waterleidingen voltooiden.

De Swaan wees erop dat de naar de buitenwijken getrokken rijke inwoners van een grote stad als eersten, uit eigen zak, riolen en waterleidingen aanlegden. Daarna sloten plaatselijke overheden de woningen van de in het stadshart oververtegenwoordigde armen aan. Waarom verliep de aanleg zo? Welgestelde inwoners verhuisden niet naar de rand van de stad en kozen niet voor riolering en waterleiding omdat ze geld voor de gemakken des levens over hadden. Ze wilden geen besmettelijke ziekten oplopen. De kans daarop bleef echter bestaan. De rijkdom werkte nog steeds in het centrum en het personeel woonde daar. Maar als rond het centrum buizen liggen, kost het een gemeente slechts weinig belastinggeld om dat centrum aan te sluiten (net zoals voor latere cellen van een honingraat minder wanden moeten worden gebouwd dan voor de eerste zeshoek). De burgerij stemde in met die overheidsingreep, omdat ze daar baat bij had. Haar besmettingskans naderde nu nul. Op eigen houtje speelden de gegoeden van een grote stad dat niet klaar, zelfs niet door bij elkaar in nieuwbouwwijken te wonen. Aldus De Swaans 'honingraathypothese'.

Hetzelfde geldt algemener en volgens de hypothesen van de nieuwe politieke economie. Bepaalde ziekten verspreiden zich door lichamelijke nabijheid en vuil water en hebben zo negatieve externe effecten. Hun bestrijding brengt soms positieve externe effecten met zich mee: als op veel plaatsen waterleidingen en riolen liggen, kunnen armlastigen nagenoeg kosteloos worden aangesloten. Dat vermindert hún kans op besmetting én die van gegoede personen. Na lang gesteggel tussen marktpartijen bant overheidsdwang collectieve kwaden (besmettelijke ziekten) uit en brengt die dwang collectieve goederen (volksgezondheid) voort.

De historicus Van der Heijden (1994) weersprak De Swaans honingraathypothese. Hij deed dat met bevindingen over de waterleiding in Tilburg: 1) de gemeente verleende in 1895 een concessie aan een naamloze vennootschap, 2) in 1906 namen de wolfabrieken maar liefst 88\% en in 1920 nog $71 \%$ af van het water van die onderneming, en 3) bij dat bedrijf had in 1899 maar $7 \%$ van de huizen een aansluiting, stijgend naar $67 \%$ in 1912 en $76 \%$ in 1920.

Helaas onderkende Van der Heijden niet dat deze bevindingen stroken met een stelling van Olson (1965), een voorganger van Van den Doel. 
Die houdt in dat bij marktmatige voortbrenging van collectieve goederen de kleinen de groten - zo die bestaan - uitbuiten. Terwijl volgens de honingraathypothese woningen water verbruiken, voorzegt de 'stelling van de omgekeerde uitbuiting' dat particuliere bedrijven voor het reinigen van wol grote hoeveelheden water aan fabrieken leveren en bijverdienen met de verkoop aan huishoudens.

\section{Onderzoeksmethoden in geschiedwetenschap en sociologie}

Voor sociologen met belangstelling voor cohesie zijn vragen over het verleden van een land gepast. Immers, een maatschappij blijkt in bepaalde mate cohesie te bezitten, als ze in grote moeilijkheden verkeert. Dat doet ze niet altijd, voor Nederland moeten sociologen terug naar de Duitse bezetting. Hoeveel voegden ze zo toe aan het werk van historici over de Tweede Wereldoorlog? Historici brachten voor het Nederlands Instituut voor Oorlogsdocumentatie (NIOD) officiële stukken bijeen. Wat putten historici uit die bronnen en verwaarloosden ze andere bronnen?

De Jong (1969-1991: 3/417), historicus en het eerste hoofd van het NIOD, schreef dat niet bekend is hoeveel Joden in Nederland in mei 1940 zelfmoord pleegden. Dat aantal was echter te vinden bij het Centraal Bureau voor de Statistiek (CBS). Ultee en Luijkx (1998) haalden telkaarten voor zelfdoding uit archiefdozen, bepaalden verscheidene regelmatigheden en verklaarden die met een meeromvattende theorie. Deze sociologen beschouwden een hoger zelfdodingscijfer als een aanwijzing voor minder maatschappelijke samenhang. Ze toonden aan dat voor Joden in de oorlogsjaren, met de toenemende uitsluiting, dit cijfer steeg.

Door landen met elkaar te vergelijken kwantificeerde Blom (1989), ook historicus en ex-directeur van het NIOD, de vraag waarom tussen 1940 en 1945 zoveel Nederlandse Joden zijn vermoord. Bloms antwoord bleef echter kwalitatief. Dat hield onder meer in dat de eerste anti-Joodse maatregelen in zekere mate strookten met de zuilenmentaliteit in toenmalig Nederland.

Een kwantitatief antwoord gaven Croes en Tammes (2004), die promoveerden bij twee sociologen (Ultee en Flap 1996). Ze brachten uit velerlei bronnen gegevens voor Nederlandse gemeenten bijeen. Als eerste berekenden ze per gemeente het tot dan onbekende percentage vermoorde Joodse inwoners. Dat deden ze door de (deels op het NIOD bewaarde) lijsten van Joodse inwoners die burgemeesters aanlegden voor de bezetter, te koppelen aan het (in de winkel verkrijgbare) boek van de Nederlandse Oorlogsgravenstichting en het Rode Kruis met gegevens over elke gedode Joodse persoon. Ze vonden flinke verschillen tussen gemeenten.

Croes en Tammes putten verder op het ministerie van Justitie uit het zuiveringsarchief data over de Duitsgezindheid van oorlogsburgemees- 
ters. Uit een daar bewaard gebleven cartotheek die was aangelegd voor de naoorlogse zuiveringen, haalden ze het aantal leden van de Vrijwillige Hulppolities (VHP) die door de bezetter in gemeenten waren opgericht. Stukken van de na de oorlog ingestelde Bijzondere Gerechtshoven leverden gegevens op over de bruutheid waarmee de Befehlshaber en de Aussenstellen van de Sicherheitspolizei (SIPO) voor verzet opgepakte personen hadden verhoord (elke gemeente op het gebied van zo'n instelling kreeg haar score). Verder vergaarden Croes en Tammes per gemeente het percentage stemmen dat volgens de verkiezingsstatistiek van het CBS op de Nationaal-Socialistische Beweging (NSB) was uitgebracht.

Ook stelden Croes en Tammes dat voor de geslaagde onderduik van Joden meer nodig was dan het adres van iemand met open mentaliteit: vervoer ernaartoe, voedselbonnen, een vals persoonsbewijs, doktershulp, zwijgende buren, een vluchtadres. Hulpnetwerken waren volgens hen groter als de alledaagse omgang minder verzuild was. Dat laatste lazen ze af aan gemeentecijfers in de volkstelling van het CBS over de hoogte van kerkelijk gemengd huwen.

Met deze data schatten Croes en Tammes multipele regressiemodellen. Die wezen uit dat het geweld van de SIPO het percentage vermoorde Joden uit een gemeente het meest opdreef. De sterkte van de VHP deed het ook stijgen, meer huwen in eigen kerkelijke kring wellicht. De gezindheid van burgemeesters had geen effect, stemmen op de NSB evenmin.

Officiële stukken gaan over mensen heel hoog of heel laag op de maatschappelijke ladder. Hoe verging het de familie Doorsnee in de oorlogsjaren? In hoeverre luisterden de mensen naar Radio Oranje, overtraden ze het uitgaansverbod, hielpen ze gezochte personen onder te duiken en deden ze andere dingen die duiden op weerstand en veerkracht? Voor die vragen vloeien bestaande bronnen niet rijkelijk. In 2005-2009 spraken de deelnemers aan Ultees seminar 'macro- en microsociologie' eerst met een grootouder over de oorlog en dan met enkele van haar of zijn oudste bekenden, bij elkaar 600 voor 1930 geboren Nederlanders. De data sloegen ze kwantitatief en kwalitatief op. De studenten analyseerden die systematisch voor werkstukken. Zo boorden sociologen een bron aan die het NIOD liet opdrogen.

\section{Hoeveel droeg Van Doorns aanvankelijke werk bij aan de sociologie?}

Moderne sociologie verankerde een nieuw vak in de universiteit, later bepleitte Van Doorn de opheffing van sociologieopleidingen. De Rijk (1986) vroeg Van Doorn of de sociologie hem nog wel interesseerde. 'Zoals die zich heeft ontwikkeld niet.' Van Doorn zei tevens: 'Ik heb Moderne 
sociologie geschreven omdat er in die tijd vraag naar was, maar ik heb zelf die denkwijze nooit echt toegepast.' Bij Bienemann (1989) verontschuldigde Van Doorn zich voor deze uitlatingen. De journalist: 'Toch kwamen Uw uitspraken hard aan. De "Godfather" van de Nederlandse sociologie komt even vertellen dat het vak eigenlijk niet bestaat.' Van Doorn: 'Zo is het overgekomen, ja. Maar wat ik bedoeld heb te zeggen is dat de sociologie niet moet verdwijnen, maar dient te veranderen.' Tja, naar wat? Verder misprees Van Doorn 'kwasi-kwantitatieve ingewikkeldheid' in de sociologie. Niet alleen was de eigen systematiek achteraf verkeerd, elke poging tot zoiets leek deze te moeten ontgelden.

Hoeveel verder bracht Van Doorn de onderzoeksmethoden van de sociologie?

Van Doorn verzamelde in de jaren vijftig zelf gegevens, maar ze verstoften bijna. Ontsporing van geweld (1970: $\mathrm{xv})$ : 'Het is ons niet meer duidelijk waarom (in 1952) de uitvoering mislukte' van de analyse van protocollen voor 80 excessen begaan in 1947-49 door Nederlandse soldaten in Nederlands-Indië. Het boek bevat geen ingevuld protocol. Zo verminderde Van Doorn de kans op navolging van zijn nieuwe onderzoeksmethode in de militaire sociologie. Wel zijn daar inmiddels de resultaten van het door de romanschrijver Grunberg opgezette literaire trainingskamp voor de Task Force Uruzgan (Van Bemmel 2009).

Van Doorn (1956a) raadde de aloude vergelijkend-historische methode aan. Door jaartallen te verzamelen en te vergelijken ontdekte hij dat, van alle Europese landen, Nederland er als eerste toe overging militairen te drillen. Dat gebeurde onder prins Maurits. De Swaan (1988) vond, ook door jaartallenvergelijking, dat de invoering van sociale wetten in Nederland leek op een 'lange sisser' met een 'late knal'. Jaartallen, hoe duf ze ook zijn, vormen een bron om vragen te beantwoorden als 'welk land drilde als eerste soldaten?' en 'waarom had Duitsland eerder sociale wetten dan Engeland?'. Overigens is de vergelijkend-historische methode intussen gesystematiseerd. Een jaartal staat voor een gebeurtenis en Allison (1984) doet een kwantitatieve methode uit de doeken die onder de vlag gebeurtenissenanalyse vaart.

'Dekolonisatie vergelijkenderwijs' bij de herdruk van Ontsporing (1983) vormt een opstapje tot gebeurtenissenanalyse. Een schema vermeldt de jaren met geweld in Algerije, Angola, Mozambique, Nederlands-Indië, Nieuw-Guinea en Vietnam. Overigens ontbreken in de figuur koloniën waar de machtsoverdracht vreedzaam verliep, zoals Ceylon (Sri Lanka), Nigeria, Senegal en Suriname. Van Doorn verschaft latere generaties een half explanandum. Een studie van Korpi en Palme uit 1983 vormt een volwaardige (en ingewikkelde) gebeurtenissenanalyse ter beantwoording van vragen over krimpende verzorgingsstaten. Deze wees uit dat 
ook onder linkse regeringen uitkeringspercentages worden verlaagd. Zulke gebeurtenissen kwamen onder een dergelijk bewind echter minder vaak voor, terwijl de verlagingen tevens minder ver gingen.

\section{Hoeveel verder bracht Van Doorn de theorieën van de sociologie?}

Moderne sociologie werd ten onrechte geroemd om haar begrippenstelsel. Een theorie behoort een uitsprakenstelsel te zijn, en hoewel er geen uitspraken zijn zonder begrippen, munten sociologen te veel begrippen zonder uitspraken. Een wetenschap met als doel onveranderlijke wezenheden achter verschijnselen te onthullen door middel van begripsbepalingen, blijft volgens Popper achterlijk. Het is niet nodig steeds termen vooraf te definiëren, omdat ze als naamkaartjes worden gebruikt en ertoe dienen lange zinnen korter te maken, en vragen over het wezen van verschijnselen ('wat is x eigenlijk?') zijn onbelangrijk, terwijl wetenschap verder komt met verklaringsvragen ('hoe komt het dat y gebeurde?') en door het leggen van verbanden tussen gebeurtenissen. Aldus het in Moderne sociologie miskende, maar niet onbekende, onderscheid tussen 'essentialisme' en 'nominalisme' (Popper 1945: 1/32-33).

Van Doorn benutte de term 'systeem' vaker. De ondertitel van Sociologie van de organisatie (1956a) is Beschouwingen over organiseren in het bijzonder gebaseerd op een onderzoek van het militaire systeem. De titel van een artikel uit dat jaar (Van Doorn 1956b) luidt 'Verzuiling: Een eigentijds systeem van sociale controle'. Ook is daar de kop 'Ontregeld beheersingssysteem' (Van Doorn 1970). Dit systeemfunctionalisme blijkt telkens arm aan uitspraken te zijn. De bevinding dat het Nederlandse leger effectiever was door het drillen van soldaten, wordt niet verklaard door te spreken over een militair systeem. Kruijt (1957) stelde dat organisatorische verzuildheid (elke gezindte haar eigen school) tot meer verzuildheid in de alledaagse omgang (wie komt bij wie over de vloer) leidde. Tot die hypothese kwam Van Doorn een jaar eerder niet met het begrip 'systeem'. In 'Ontregeld beheersingssysteem' staat dat in oorlogstijd de wet zwijgt en het leger recht spreekt, met alle gevolgen van dien. Deze stelling verklaart op zijn hoogst dat geweld ontspoorde, niet hoeveel uitwassen er waren. En verklaart slappe rechtspraak excessen? Die gedachte ziet een remedie aan voor een oorzaak.

Van Doorn (1965) stelt dat 'beroepsvorming in internaatsverband' tot effectievere beroepsuitoefening leidt. Tijdens een bezoek in 1967 van de Utrechtse Sociologische Studenten Vereniging aan de Koninklijke Militaire Academie te Breda vroeg de derdejaars Ultee aan Van Doorn of het wegjagen van langharig tuig door mariniers uit de hal van het Centraal Station te Amsterdam, waar de meisjes van de jantjes lastig werden gevallen na het vertrek van hun geliefden naar Den Helder, wat 
te maken had met het kazerneleven. 'Iets', zei Van Doorn, waarna hij om de volgende vraag vroeg. Van Doorn (1956a) had over disfuncties van systemen gerept, in 1967 bleef het disfunctionalisme uitspraakloos.

Michels beweerde een eeuw geleden dat iedere democratische organisatie volgens een ijzeren wet naar oligarchie tendeert. Van Doorn (1969a) stelde dat het Chinese staatshoofd Mao die wet met een culturele revolutie wilde doorbreken. Socioloog Tromp steigerde, Van Doorn (1973) gaf iets toe, maar volgens Tromp (1977) niet genoeg. Socioloog Wippler (1983) schreef oligarchieverklaringen uit. De diskwalificatie 'kwasikwantitatieve ingewikkeldheid' sloeg onder meer op dit stuk, zo denkt Wippler nog altijd. Als mensen steeds stemmen op ervaren bestuurders, wordt een democratische organisatie oligarchisch. Rationeel individueel gedrag heeft irrationele maatschappelijke gevolgen. Aldus Wippler.

Van Doorn (1969b) besprak een boek van Albert over de mate waarin organisaties en markten de handelingen van grote aantallen mensen op elkaar afstemmen. Hij zag, naast de organisatiesociologie, een marktsociologie oprijzen. Dat beviel hem, maar hij miskende dat het door Albert bepleite onderzoeksprogramma brede steun vond en pas de nieuwe politieke economie had voortgebracht. Van Doorn (1988) ging nog voorbij aan die theorie. Ze zegt onder welke omstandigheden individuele rationaliteit leidt tot maatschappelijke irrationaliteit, collectieve kwaden, mislukte sturing door organisaties en onderbezettingsevenwichten op markten. Van Doorn verving het systeemfunctionalisme niet door een inhoudsrijker structureel individualisme, Wipplers naam voor het programma van Albert en anderen.

Hoeveel verder bracht Van Doorn de hoofdvragen van de sociologie?

Onder de kop 'Het probleem van de militaire organisatie opnieuw gesteld' verwierp Van Doorn (1956a) twee stellingen over het wezen van legers. De ene luidt dat legers uit vechtersbazen bestaan, de andere dat legers van wie dan ook vechters maken. Wat is een leger dan wel? Van Doorn: een doelgerichte organisatie die beschikt over min of meer effectieve en efficiënte middelen. Achter deze essentialistische vraag steekt overigens een omvattende verklaringsvraag, en wel Webers rationaliseringsvraag. Legers hebben als disfunctie gebiedsuitbreiding en als functie verdediging van landsgrenzen. McNeill (1983) en Pick (1993) wezen op omstandigheden waaronder legers hun functie effectiever en efficiënter vervullen.

Godsdienstsocioloog Kruijt (1957) verzamelde cijfers over verzuildheid in Nederland. Daarmee konden latere generaties trend- en verklaringsvragen stellen over dit onderdeel van de (dis)cohesievraag. Van Doorn (1956b) bevatte zulke gegevens niet. Stratificatiesociologen Van 
Heek en Vercruijsse (1958) en Van Tulder (1962) lieten een beroepsprestigeladder na, cijfers over stijging en daling op die ladder, evenals een tabel met gegevens over wie-trouwt-met-wie. Hun data betroffen Nederland in 1953 en 1954. Met die gegevens konden latere generaties trenden verklaringsvragen aanvatten. Deze generaties gingen voorbij aan Van Doorn (1955), volgens welke stratificatie een polyhiërarchie is. Weer een antwoord op een essentialistische vraag.

Ontsporing (1970) bevat Van Doorns belangrijkste (dis)cohesievraag: hoeveel geweld gebruikte het Nederlandse leger tegen inwoners van een overzees gebiedsdeel die een onafhankelijk Indonesië nastreefden en waarom deed het dat? Die vraag is beschrijvend én verklarend. Hoe omstandig zijn de beschrijvingen? In Ontsporing ontbreekt het totale aantal omgekomen Indonesische militairen en burgers. Volgens pagina 141 is het aantal gesneuvelden tijdens de eerste politionele actie op Oost-Java aan Indonesische kant vele malen het aantal gesneuvelden aan Nederlandse zijde. Pagina 151 vermeldt de aantallen bij alle acties in heel Indonesië omgekomen Nederlandse militairen. Op pagina 216-217 staat het aantal huizen dat Van Doorns compagnie tussen januari 1948 en augustus 1949 in brand stak, het aantal door haar gedode burgers en gevangenen, alsook het aantal uitgevoerde derdegraadsverhoren.

Van Doorn geeft verder 'een gekwantificeerd overzicht van defensief en offensief optreden in het (door hem bestudeerde) operatiegebied' tijdens de tweede politionele actie. Dat overzicht, pagina 239, 'spreekt voor zich'. Er waren 12 grote optredens van Nederlandse troepen, 26 aanvallen van de tegenstander op detachementen en 42 op patrouilles. Maar wat zegt de verhouding tussen het aantal offensieve en defensieve acties? Bij de eerste politionele actie vielen verhoudingsgewijs meer Indonesische soldaten.

Kunnen trouwens verklaringsvragen over excessen worden beantwoord met data voor één geval? De vraag van de herdrukte Ontsporing vergelijkt in elk geval dekoloniseringen. Het antwoord behelst vier losse factoren. Het systeemfunctionalisme is voorbij.

\section{Intermezzo: waarom zag Van Doorn de sociologie niet meer zitten?}

De Beus beweerde na Van Doorns overlijden (Vlasboom 2008): 'Er wordt vaak gezegd dat Van Doorn de sociologie vaarwel heeft gezegd. Als dat zo is, waarom dan? Van Doorn dacht in groepen, in geordende collectiviteiten. Hij zag die groepen, en daarmee het object van de sociologie, verdwijnen in individualisering.' De Beus doelt op cohesie, maar ongelijkheid en rationalisering zijn ook hoofdvragen van de sociologie. Hadden die afgedaan? 
In elk geval de ongelijkheidvraag. Op bezoek bij Nijmeegse sociologen zei Van Doorn op 29 oktober 1999 alleen geschiedenis te lezen. Wat gebeurde er nou in de Nederlandse sociologie? Need wees op onderzoek dat meer sociale mobiliteit in Nederland aantoonde. Het weerwoord: ongelijkheid is van alle tijden. Maar is ze altijd even groot? Zijn meer/ minder vragen slechter dan welles/nietes kwesties? Ultee vroeg Van Doorn niet of hij de bestaande ongelijkheden onveranderlijk en functioneel achtte.

Bijgaand vragenplaatje (figuur 1) wijst uit dat Van Doorns werk - zijn sociologische werk én zijn historische werk - aan systematiek wint met cohesie en discohesie als hoofdvraag.

Figuur 1 Vragen uit Van Doorns afzonderlijke studies verenigd tot cohesievragen

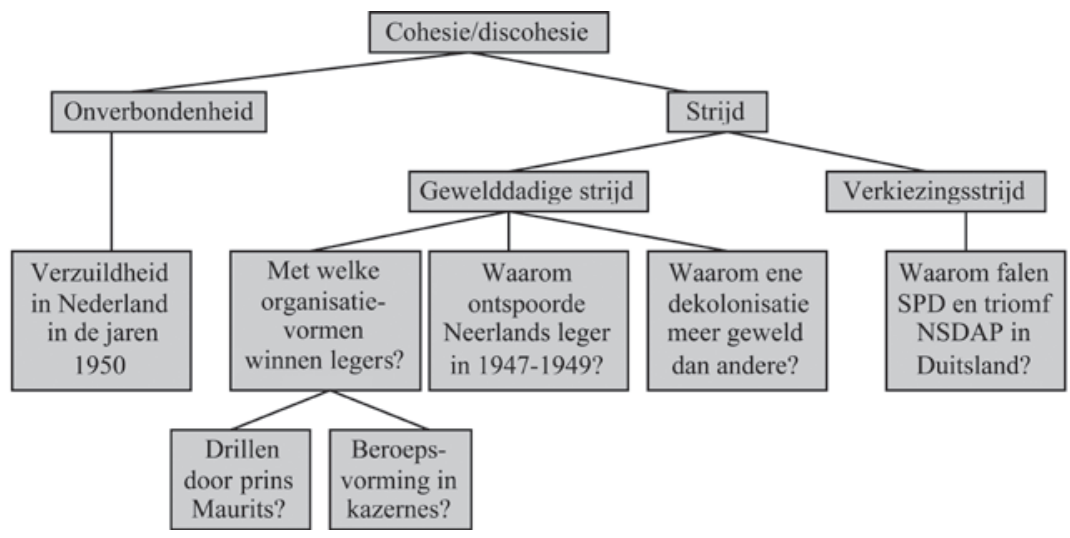

\section{Hoe bedreef Van Doorn later geschiedwetenschap?}

Van Doorn liet in 1994 De laatste eeuw van Indië het licht zien en in 2007 Duits socialisme. Volgens velen werd hij met die boeken over vroeger historicus. Zijn ze goede geschiedenis?

\section{Onderzoeksmethoden in Van Doorns geschiedwerken}

Van Doorn (1994) onderzoekt Indische wetten: het monopolie van de VOC in de achttiende eeuw, het daarna tot 1830 geldende landrentestelsel, het daarop volgende cultuurstelsel, en de Wet de Waal van 1870. Zijn methode komt neer op een veredelde jaartallenvergelijking: geven latere wetten Nederlanders in Nederlands-Indië meer ruimte tot handelen dan eerdere? Daarmee vertoont deze historische analyse systematiek. Het falen van de sociaal-democratie en de triomf van het nationaal-socialisme, de ondertitel 
van Duits socialisme, zinspeelt op verkiezingen. Van de uitslagen bespreekt Van Doorn (pagina 30) 'enkele cijfers'. Alle percentages staan in tabel 1. Ditmaal blijken Van Doorns analyses fragmentarisch te zijn.

Tabel 1 Percentage stemmen voor de belangrijkste politieke partijen bij alle verkiezingen voor de Rijksdag in Duitsland van 1919 tot $1933^{1}$

\begin{tabular}{llllllllll}
\hline & 1919 & 1920 & $1924[1]$ & $1924[2]$ & 1925 & 1928 & $1932[1]$ & $1932[2]$ & 1933 \\
\hline KPD & - & 2,1 & 12,6 & 9,0 & 10,6 & 13,1 & 14,5 & 16,9 & 12,3 \\
USDP & 7,6 & 17,9 & 0,8 & 0,3 & 0,1 & 0,0 & - & - & - \\
SPD & 37,9 & 21,7 & 20,5 & 26,0 & 29,8 & 24,5 & 21,6 & 20,4 & 18,3 \\
DDP & 18,6 & 8,3 & 5,7 & 6,3 & 4,9 & 3,8 & 1,0 & 1,0 & 0,9 \\
DVP & 4,4 & 13,9 & 9,2 & 10,1 & 8,7 & 4,7 & 1,2 & 1,9 & 1,1 \\
Zentrum & 15,9 & 13,6 & 13,4 & 13,6 & 12,1 & 11,8 & 12,5 & 11,9 & 11,2 \\
BVP & 3,8 & 4,2 & 3,2 & 3,8 & 3,1 & 3,0 & 3,7 & 3,4 & 2,7 \\
DNVP & 10,3 & 15,1 & 19,5 & 20,5 & 14,2 & 7,0 & 6,2 & 8,9 & 8,0 \\
NSDAP & - & - & 6,5 & 3,0 & 2,6 & 18,3 & 37,4 & 33,1 & 43,9 \\
Overig & 1,6 & 3,3 & 8,6 & 7,5 & 13,9 & 13,8 & 2,0 & 2,6 & 1,6 \\
Opkomst & 83,0 & 79,2 & 77,4 & 78,8 & 75,6 & 82,0 & 84,1 & 80,6 & 88,8 \\
\hline
\end{tabular}

Zegevierden de nazi's (NSDAP) en waren het de sociaal-democraten (SPD) die faalden? Pagina 30: 'De nazi's waren op dat moment (1932[1]) met $37,4 \%$ de grootste partij, van vrijwel gelijke sterkte als de SPD $(37,9 \%)$ in 1919.' Van Doorn doet hier alsof iedereen die in 1919 voor de SPD koos, in 1932 NSDAP stemde. Klopt dat? Over deze 'inwisselhypothese' zo meer. En waarom cijfers voor 1919, toen de communisten (KPD) nog niet meededen? In 1920 was de SPD bijna even groot als in 1932[2] (21,7 en 20,4\%). De KPD steeg tussen 1924[1] en 1932[2] van 12,6 naar 16,9\%. De nazi's klommen na $1925(2,6 \%)$ sterk op. Maar bij de tweede verkiezing van 1932 (de laatste voor de brand in de Rijksdag op 27 februari 1933 en de opschorting meteen daarna van de politieke grondrechten), behaalden ze een lager percentage $(33,1)$ dan bij de eerste van dat jaar $(37,4)$. De liberalen (DDP+DVP) kelderden (van 23,0\% in 1919 naar 2,9\% in 1932[2]).

\section{Theorieën in Van Doorns geschiedwerken}

Volgens De laatste eeuw hadden bestuursambtenaren en ingenieurs veel handelingsruimte bij de aanleg van bruggen, spoorlijnen en wegen. Die gebruikten ze ook door hun dadendrang. Het koloniale project mislukte evenwel, omdat deze kansen voorbehouden bleven aan Nederlanders. Deze gedachte lijkt op Webers wereldbeeldenhypothese.

Volgens Duits socialisme was de SPD enigszins nationalistisch. Ze was dat niet genoeg en verloor terrein aan de NSDAP. Volgens haar naam 
richtte die partij zich op arbeiders, nationalisme en socialisme voorstaande. Van Doorn wuift een andere verklaring van de verkiezingsuitslagen weg. Pagina 32: 'Dat de NSDAP vooral sinds 1930 veel leden trok en electorale successen boekte, werd verklaard uit de diepe economische depressie. (...) Er is een heel andere interpretatie mogelijk. (...) de politieke eindstrijd in Weimar (was) niet alleen een keuze tussen democratie en dictatuur, maar ook een steeds feller gevoerd gevecht tussen drie varianten van het socialisme: de sterkste sociaal-democratische partij van Europa, de grootste communistische partij buiten de Sovjet-Unie en de meeste ambitieuze en agressieve representant van het nationale neosocialisme dat in het interbellum overal zichtbaar werd.' Maakte de sinds 1929 sterk oplopende werkloosheid die strijd niet feller?

In hoeverre klopt Van Doorns hypothese dat Duitse kiezers van sociaal-democratie naar nationaal-socialisme wisselden? Opeenvolgende uitslagen voor landen zeggen weinig over wisselende kiezers. Gegevens over (kleinere) kieskringen vertellen daarover meer. Falter (1991) paste op die data ecologische regressie toe. De uitkomsten staan in tabel 2.

Tabel 2 Percentage kiezers voor een bepaalde partij bij een bepaalde verkiezing voor de Rijksdag in Duitsland dat bij de volgende verkiezing NSDAP stemde (leesvoorbeeld: van elke 100 personen die in 1928 op de SPD stemden, stemden er 10 in 1930 op de NSDAP) ${ }^{2}$

\begin{tabular}{lrrrrrrrr}
\hline & KPD & SPD & $\begin{array}{c}\text { DDP+ } \\
\text { DVP }\end{array}$ & $\begin{array}{c}\text { Z+ } \\
\text { BVP }\end{array}$ & DNVP NSDAP Overig & $\begin{array}{c}\text { Niet } \\
\text { gestemd }\end{array}$ \\
\hline $1920 / 1924[1]$ & 7 & 3 & 8 & 4 & 8 & - & 6 & 3 \\
$1924[1] / 1924[2]$ & 3 & 1 & 2 & 2 & 3 & 13 & 3 & 1 \\
$1924[2] / 1928$ & 2 & 1 & 3 & 2 & 1 & 8 & 3 & 2 \\
$1928 / 1930$ & 5 & 10 & 26 & 9 & 31 & 38 & 11 & 14 \\
$1930 / 1932[1]$ & 5 & 16 & 36 & 10 & 33 & 85 & 49 & 19 \\
$1932[1] / 1932[2]$ & 4 & 6 & 4 & 6 & 0 & 76 & 11 & 2 \\
$1932[2] / 1933$ & 9 & 6 & 23 & 3 & 34 & 92 & 33 & 42 \\
\hline
\end{tabular}

Tussen de verkiezingen van 1928 en 1930 wisselden kiezers op de DNVP (een kleine nationalistische partij) en liberale kiezers het vaakst naar de NSDAP (31 en $26 \%$ ), thuisblijvers en stemmers op overige partijen minder (14 en 11\%), SPD-kiezers nog minder (10\%), en KPD-kiezers het minst (5\%). Hetzelfde geldt voor de verkiezingen van 1930 en de eerste van 1932: van de stemmers op DNVP en de liberalen wisselde 33 en $36 \%$, van de thuisblijvers en overige kiezers 19 en $49 \%$, van de SPD-kiezers $16 \%$ en van de KPD-kiezers 5\%. De inwisselhypothese is niet houdbaar.

Ging de strijd in Duitsland trouwens om stemmen? Met de moord op Rathenau in 1922, de staatsgreep van de nazi's in 1923 en het straat- 
geweld van de paramilitaire armen van politieke partijen, verloor de staat er het monopolie op de geweldsmiddelen. En al vroeg waren Joodse begraafplaatsen en winkels doelwit van de Sturmabteilung van de NSDAP. Van Doorn (pagina 225) omtrent antisemitisme, een loot van nationalisme: 'Over de houding van de Duitse bevolking ten opzichte van de joodse minderheid is te veel en te controversieel geschreven om in het bescheiden bestek van ons betoog een resoluut oordeel te kunnen wagen.'

Volgens Tromp (2007) roepen de slotzinnen van Duits socialisme een tot dan door Van Doorn niet gestelde, laat staan beantwoorde, vraag op. Dat besluit luidt (pagina 271): 'Het nationaal-socialisme, zou men kunnen zeggen, voltooide de geschiedenis van het Duitse socialisme door identiek te worden met Duitsland. Om dat Duitse socialisme vervolgens te vernietigen door er de laatste, meest extreme consequenties uit te trekken, die, zoals bekend, "zum Teufel führen".' Tromp vermeldt dat de non-vraag de samenhang is tussen de nationaal-socialistische verzorgingsstaat en de oorlogszucht en rassenhaat van dit regime. De allerlaatste zin suggereert, zo Tromp, als antwoord daarop dat het ene onlosmakelijk was verbonden met het andere. Oppert, dus geen systematische analyse en evenmin een fragmentarische. Toch eindigt de ondertitel van Duits socialisme met ... de triomf van het nationaal-socialisme. Welke triomf? Het duivelse kwaad dat Van Doorn niet noemt, omschreef Wielek als De oorlog die Hitler won (1947) en Dawidowicz als The War against the Jews 19331945 (1975).

\section{Vragen in Van Doorns geschiedwerken}

Van Doorns vraag waarom het nationaal-socialisme zegevierde en de sociaal-democratie faalde is verkeerd. Het grootste falen was de val van de liberalen. De vraag is tevens onjuist, want de SPD bleef overeind. De vraag is ook fout, omdat er geen eerlijke verkiezingen waren nadat Hitler rijkskanselier werd. Ze is daarnaast verkeerd, omdat bij de eerste oneerlijke de NSDAP noch een overweldigende, noch een absolute meerderheid behaalde.

De laatste eeuw draait volgens Van Doorn altijd om de vraag: wat was 'Indië'? Dat is een essentialistische, verwerpelijke vraag. Tegen Meijer (1994) zei Van Doorn wat anders: 'Ik probeer verschillende vragen, ben steeds op zoek naar het antwoord op die kernvraag uit de sociologie: hoe maatschappelijke orde eigenlijk mogelijk is.' Toch sociologie, maar weer mis. Gezien de hoofdstukindeling was Van Doorns vraag: hoe activistisch was het beeld dat Nederlanders gedurende hun laatste eeuw in Indië hadden van de verhouding tussen hen en de Indische wereld, en welke gevolgen had dat beeld voor de rust in het land, de ongelijkheid en de ontwikkeling? Van Doorns geschiedenis kwam uit bij een sociologie met drie hoofdvragen. 


\section{Toegift: herfsttij der democratie?}

Nederland is een representatieve democratie, maar in geïndividualiseerde landen besluiten overheden moeizaam, en als de leiders van eens groepsgebonden partijen die uitdaging niet aankunnen, ontstaat populisme en breekt het 'herfsttij der democratie' aan. Aldus Van Doorn (2009). Deze studie bleef fragmentarisch. Daarom nu een meer systematische analyse.

Dit betoog gaat uit van cijfers over verkiezingen in Lipset (1981) en Castells (1997). Ook grijpt het terug op uitspraken van Weber (1921: 124) over gezag. Verder is daar de hypothese van Castells (1997: 317) volgens welke de media een eigen logica hebben. Deze logica lijkt op Poppers 'logica van de situatie' (1957), Gombrichs 'kermis van de ijdelheid' (1974) en Boudons 'logica van het sociale' (1981) uit het structureel individualisme.

Onderscheidend tussen links en rechts liet Lipset (1981: 505) zien dat verschillen tussen klassen in stemgedrag voor westerse landen tussen 1948 tot 1980 afnamen. Castells stelde dat aan het eind van die tijd naast oud links nieuw links ontstond en naast oud rechts nieuw rechts. Met cijfers die lopen van 1980 tot 1994 toonde hij aan dat het stemmen op nieuwe partijen stijgt (Castells 1997: 347). Hoe zijn beide trends te verklaren?

De eenvoudige verklaring luidt dat door de voortschrijdende techniek en de uitdijende verzorgingsstaat maatschappijen minder gelaagd raken en ontkerstenen. Eens: overerving van ongeschoolde handarbeid, winkels en fabrieken. Nu: stijging en daling op een ladder met uitkeringstrekkers, laaggeschoolden, kleine zelfstandigen, hooggeschoolde werknemers in het bedrijfsleven, hooggeschoolde werknemers bij de (semi)overheid en hogere leidinggevenden. Verder verloren de kerken terrein met de groei van het onderwijs en de komst van de verzorgingsstaat. Hoe hoger de opleiding van een persoon, des te groter diens kans op kerkverlating; en hoe ruimer de uitkeringsrechten van een persoon, des te zwakker diens band met (liefdadige) kerken. Zo verloren partijen die zich op een groep links of rechts richtten, hun vaste aanhang.

Er speelt echter meer. Mensen met een 'bestemming' die verschilt van hun 'herkomst', stemmen met grotere kans op een partij die noch bij hun herkomst, noch bij hun bestemming past. Een kind van een handarbeider, bijvoorbeeld, hoorde thuis negatieve zaken over de VVD, en mijdt die partij als het kind sociaal stijgt. Iets dergelijks geldt voor dalers en onkerkelijk geworden personen. Links en rechts is ruimte voor nieuwe partijen. Een nieuw links strijdpunt is een schoon milieu, een nieuw rechts strijdpunt vormen de aanspraken van nieuwkomers op de verzorgingsstaat. 
Waarom slagen linkse én rechtse nieuwe partijen? Weber noemde drie legitimeringen van het monopolie op de geweldsmiddelen: traditioneel, charismatisch en legaal gezag. Die begrippen leiden tot twee hypothesen. De ene: door democratisering en industrialisering maken traditioneel en charismatisch gezag plaats voor legaal gezag. In Webers tijd waren krant en boek de enige massamedia. Later kwam echter de radio en daarna de televisie. De kabel bracht nog meer mededingers. Media gingen politiek verpakken en bijknippen om publiek te werven. Die strijd wint de buis als ze de camera richt op politici die door hun wereldbeeld daadkracht uitstralen. De tweede hypothese: met democratisering en industrialisering maakt traditioneel gezag plaats voor charismatisch en legaal gezag.

Welnu, nieuwe partijen hebben zelden traditioneel gezag, terwijl ze nog legaal gezag moeten verwerven. Als ze het maken, kan dat alleen door charismatisch gezag van hun leiders. Volgens Castells krijgen die dat in de schoot geworpen door de logica van medialand.

1. Als in een samenleving de wedijver tussen massamedia toeneemt,

2. heeft de voorkeur van lezers, luisteraars en kijkers voor vermaak boven nieuws tezamen met de afstandelijkheid die media uit geloofwaardigheid in acht nemen,

3. tot gevolg dat politieke standpunten worden teruggebracht tot voor/ tegen, nieuwe partijen en politici meer aandacht krijgen, en meer over personen dan standpunten wordt gezegd,

4. leidend tot meer stemmen voor partijen op één van de extremen in het politieke spectrum.

\section{Het herfsttij voorbij? De Tweede Kamer gevierendeeld}

Met Moderne sociologie konden organisaties hun voordeel doen. Ook zouden sociologisch geschoolde beleidsmedewerkers de samenleving rationeler maken (De Rijk 1986). Die doelen werden hoogstens gedeeltelijk bereikt. De sociologie weet te weinig. Maar verder kan de overheid op een andere manier met bestaande sociologische kennis aan legaal gezag winnen. Dat is de toepassing van sociologische kennis bij het ontwerpen van politieke instellingen.

De roep om meer invloed op de politiek werd in Nederland luider voordat de gevolgen van klassenversplintering en ontzuiling intraden. Den Uyls inspraakprocedures staalden de ijzeren wet van de oligarchie. D66 beoogt nog steeds volksraadplegingen, een gekozen premier en kiesdistricten. Referenda stroken echter niet met een representatieve democratie, een gekozen premier leidt tot gedwongen samenleven (zoals in de Franse Vijfde Republiek), en hoe zijn grenzen tussen kiesdistricten te trekken? In de Verenigde Staten worden ze verlegd als de tienjaarlijkse 
volkstelling verschuivingen in bewonersaantallen uitwijst. De heersende partij maakt dan nieuwe grenzen die haar in het zadel houden. Hoe valt, met sociologische kennis, het trilemma van drie hervormingen met ongewenste gevolgen te vermijden?

Onderhavig voorstel ter vergroting van legaal gezag in Nederland past in het structureel individualisme, de nieuwe politieke economie en wat De Beus (1994) 'het nieuwe rationele-keuze institutionalisme' noemt. Het benut een verbetering van de stelling dat democratische staten, door belastingheffing en wetten, optimaal collectieve goederen voortbrengen. In lijn met Poppers hypothetisch-deductief model, pas ik daarbij het algemene beginsel dat mensen rationeel handelen toe onder nieuwe aanvangsvoorwaarden.

Een strijdkreet van de Amerikaanse Revolutie uit 1776 was No taxation without representation. Voor wat hoort wat, maar waarom destijds eens in de vier jaar verkiezingen en waarom nu nog? Sinds de komst van algemeen kiesrecht verviervoudigde in Nederland de belastingdruk. Daarom: des te hoger de belastingdruk, des te vaker verkiezingen. Zo behoren elk jaar verkiezingen te worden gehouden. Maar dan komt Nederland van de regen in de drup.

Volgens Olson moet 'de' overheid negatieve externe effecten inperken. Dat gebeurt volgens Van den Doel optimaal bij algemeen (niet bij beperkt) kiesrecht. Volgens schrijver dezes zal dit pas het geval zijn bij algemeen kiesrecht voor afzonderlijke overheden die zich richten op onderscheiden collectieve kwaden. De idee dat één overheid elk negatief extern effect van individueel handelen vermijden en elk collectief goedmaken moet, is misleidend. Er zijn vele collectieve kwaden in te dammen en vele collectieve goederen te vervaardigen.

Ik stel voor de Tweede Kamer te splitsen, en wel in vieren. Elke kamer brengt bepaalde collectieve goederen voort, houdt eigen verkiezingen, heft zelf belasting en heeft afzonderlijke ministers. Partijen moeten voor elke kamer een lijst indienen en een persoon mag voor slechts één kamer op een lijst staan. De vier verkiezingen worden eens in de vier jaar op dezelfde onverschuifbare datum gehouden. Tussentijdse verkiezingen mogen een jaar ervoor en erna niet. De Eerste Kamer blijft zoals die is: ze wordt gekozen door de Provinciale Staten en zegt alleen ja of neen tegen elk wetsvoorstel dat het in één van de kamers haalde.

Welke kamers komen er? Een Kamer voor Volksgezondheid, één voor Onderwijs en Wetenschap, een Uitkeringenkamer en een Brede Kamer. Deze keus stoelt op begrotingen en deskundigheden. In de jaren 1960 werd defensie ingehaald door onderwijs als grootste uitgavenpost van de staat, nu wordt aan sociale voorzieningen even veel geld besteed als aan onderwijs. In de laatste rijksbegrotingen zijn de collectieve kwaden waarnaar het meeste geld gaat ziekte, inkomensverlies bij niet-werken, 
en ongeletterd- en ongecijferdheid samen met beroepsonbekwaamheid. Het bestaan van afzonderlijke ministeries wijst er verder op dat de voortbrenging van volksgezondheid, sociale voorzieningen en een hoogopgeleide bevolking uiteenlopende deskundigheden vereisen. Daarom krijgen deze goederen een aparte kamer. Het hoofd van de regering van de Brede Kamer vertegenwoordigt Nederland in het buitenland.

Het vierkamerstelsel vermindert charismatisch gezag, er is nooit één leider. Ook daalt de afkeer van politiek. 'De' politiek bestaat niet. En omdat concrete collectieve kwaden meer aandacht trekken dan algemene beschouwingen, stijgt het legaal gezag. De vier kamers bij elkaar heffen nooit $100 \%$ belasting. De vier verkiezingen vallen op dezelfde dag en iedere partij stelt voor elke kamer kandidaten. Ook de Eerste Kamer, die alle voorstellen van alle kamers wel of niet tot wet verheft, vormt een rem op het tegen elkaar opbieden door kamers.

Nieuw is de idee van veel verkiezingen niet. Nederland kent al lang afzonderlijke verkiezingen voor gemeente, provincie en rijk. Onlangs kreeg Nederland er een verkiezing bij. Dat gebeurde omdat belasting zonder stemrecht niet te wettigen viel. Waterschappen kregen waterzuivering als taak erbij, wat ertoe leidde dat iedereen daarvoor door een waterschap werd aangeslagen. Het percentage uitgebrachte stemmen bij de waterschapsverkiezingen bleef bepaald laag. Bij minieme belastingbedragen valt echter weinig anders te verwachten. De belastingen die burgers voor elk van de vier kamers opbrengen zijn vele malen hoger. Het vierkamerstelsel bouwt voort op de wijze waarop de Tweede Kamer nu besluiten voorbereidt. Het kent commissies met deskundigen uit alle partijen. Enkele daarvan worden volgens onderhavig voorstel een volwaardige kamer. Hun deskundigheid verhoogt het legale gezag.

Mijn hypothese ter kering van het door Van Doorn ingeluide herfsttij der democratie houdt in dat een vierendeling van de Tweede Kamer de democratie doet opbloeien en het legale gezag laat toenemen.

\section{Facit}

Met Moderne sociologie wilde Van Doorn de twist beslechten om de voorrang van óf theorie óf onderzoek. Ook zijn latere werk ging er grotendeels aan voorbij dat wetenschap met vragen begint en verder komt door verkeerde vragen te vermijden en na de beantwoording van beschrijvingsvragen tot verklaringsvragen over te gaan. Na de neergang van het systeemfunctionalisme schoof Van Doorn niet het structureel individualisme of de nieuwe politieke economie naar voren als theoretische alternatieven. Wel kwam hij uit bij Webers wereldbeeldenhypothese. Jaartallenvergelijking was de voornaamste methode van onderzoek in zowel Van Doorns historisch als zijn sociologisch werk. Deze methode is 
ondertussen gesystematiseerd tot gebeurtenissenanalyse. Aanvankelijk beoogde Van Doorn toepassing van sociologie door beleidsmedewerkers bij de bestaande overheid. Later had hij geen oog voor wetswijzigingen die zijn ingegeven door sociologische theorieën en waarbij een staat wordt geschapen waarop kiezers meer invloed hebben.

\section{Noten}

1. Bron: Falter (1991: 25).

2. Bron: Falter (1991: 111).

\section{Geraadpleegde literatuur}

Allison, P. (1984), Event History Analysis, Beverly Hills: Sage.

Bemmel, N. van (red.) (2009), Task force Uruzgan: Literair trainingskamp, Amsterdam: Meulenhoff.

Beus, J.W. de (1994), 'Het nieuwe rationele-keuze institutionalisme', Beleid en maatschappij 21: 246-260.

Bienemann, J. (1988), 'De sociologie is geen tovermand vol ethische normen', Elsevier, 19 november 1988.

Blom, J. (1989), Crisis, bezetting en herstel. Tien studies over Nederland 19301950, Den Haag: Nijgh \& Van Ditmar.

Boudon, R. (1981), De logica van het sociale. Een inleiding tot sociologisch denken, Alphen aan den Rijn: Samsom.

Castells, M. (1997), The Information Age. Economy, Society and Culture (The Power of Identity, Volume II), Oxford: Blackwell.

Croes, M. en P. Tammes (2004), 'Giflaten wij niet voortbestaan': Een onderzoek naar de overlevingskansen van joden in Nederlandse gemeenten, 1940-1945, Amsterdam: Aksant.

Dawidowicz, L. (1975), The War against the Jews 1933-1945, New York: Holt, Rinehart and Winston.

Doel, J. van den (1975), Demokratie en welvaartstheorie. Een inleiding in de nieuwe politieke economie, Alphen aan den Rijn: Samsom.

Doorn, J.A.A. van (1955), 'Het probleem van de beroepsstratificatie', Sociologische gids 2: 88-93.

Doorn, J.A.A. van (1956a), Sociologie van de organisatie. Beschouwingen over organiseren in het bijzonder gebaseerd op een onderzoek van het militaire systeem, Leiden: Stenfert Kroese.

Doorn, J.A.A. van (1956b), 'Verzuiling. Een eigentijds systeem van sociale controle', Sociologische gids 3: 41-49.

Doorn, J.A.A. van (1961), 'Sociologie en geschiedenis', Sociologisch jaarboek 14: 30-46. 
Doorn, J.A.A. van (1965), 'De creatie van een korps. De actualiteit van een oude formule', in: J.A.A. van Doorn (red.), Beroepsvorming in internaatsverband. Sociologische beschouwingen en specifieke ervaringen, Rotterdam: Universitaire Pers, p. 66-81.

Doorn, J.A.A. van (1969a), 'De voortgezette revolutie. China en de ijzeren wet der oligarchie', Sociologische gids 16: 155-178.

Doorn, J.A.A. van (1969b), 'Pleidooi voor een marktsociologie', Mens en maatschappij 44: 330-334.

Doorn, J.A.A. van (1973), Met man en macht. Sociologische opstellen over maatschappelijke mobilisering, Meppel: Boom.

Doorn, J.A.A. van (1988), Rede en macht. Een inleiding tot beleidswetenschappelijk inzicht, Den Haag: VUGA.

Doorn, J.A.A. van (1994), De laatste eeuw van Indië. Ontwikkeling en ondergang van een koloniaal project, Amsterdam: Bert Bakker.

Doorn, J.A.A. van (2007), Duits socialisme. Het falen der sociaal-democratie en de triomf van het nationaal-socialisme, Amsterdam: Mets \& Schilt.

Doorn, J.A.A. van (2009), Nederlandse democratie. Historische en sociologische opstellen, Amsterdam: Mets \& Schilt.

Doorn, J.A.A. van en W.J. Hendrix (1970), Ontsporing van geweld. Over het Nederlands/Indisch/Indonesisch conflict, Rotterdam: Universitaire Pers.

Doorn, J.A.A. van en W.J. Hendrix, (1983), Het Nederlands/Indonesisch conflict. Ontsporing van geweld, Dieren: De Bataafsche Leeuw.

Doorn, J.A.A. van en C.J. Lammers (1959), Moderne sociologie. Systematiek en analyse, Utrecht: Aula.

Falter, J. (1991), Hitlers Wähler, München: Beck.

Gombrich, E. (1974), 'The Logic of Vanity Fair. Alternatives to Historicism in the Study of Fashions, Style and Taste', in: A. Schillp (red.), The Philosophy of Karl Popper, La Salle, Illinois: Open Court, p. 925-957.

Heek, F. van en E. Vercruijsse (1958), 'De Nederlandse beroepsprestigestratificatie', in: F. van Heek (red.), Sociale stijging en daling in Nederland, Leiden: Stenfert Kroese, p. 11-48.

Heijden, C. van der (1994), 'De Swaan getoetst. De aanleg en diffusie van het waterleidingstelsel in de industriestad Tilburg als collectief verzorgingsarrangement (1880-1910)', Tijdschrift voor sociale geschiedenis 20: 52-76.

Hoof, J. van en J. van Ruysseveldt (1996), Sociologie en de moderne samenleving. Maatschappelijke veranderingen van de industriële omwenteling tot in de 21ste eeuw, Amsterdam: Boom.

Huizinga, J. (1919), Herfsttij der Middeleeuwen, Haarlem: Tjeenk Willink.

Huizinga, J. (1929), 'Cultuursociologische verkenningen', herdrukt in: J. Huizinga (1947), Verzamelde werken VII, Haarlem: Tjeenk Willink, p. 35-94. 
Jong, L. de (1969-1991), Het Koninkrijk der Nederlanden in de Tweede Wereldoorlog, Den Haag: Staatsuitgeverij.

Korpi, W. en J. Palme (2003), 'New Politics and Class Politics in the Context of Austerity and Globalization. Welfare State Regress in 18 Countries, 1975-1985', American Political Science Review 97: 425-466.

Kruijt, J.P. (1957), 'Levensbeschouwing en groepssolidariteit in Nederland', Sociologisch jaarboek 11: 29-75.

Laeyendecker, L. (1981), Orde, verandering, ongelijkheid: Een inleiding tot de geschiedenis van de sociologie, Amsterdam: Boom.

Lenski, G. (1966), Power and Privilege. A Theory of Social Stratification, New York: McGraw-Hill.

Lipset, S.M. (1981), Political Man. The Social Bases of Politics (Expanded Updated Edition), Baltimore: Johns Hopkins University Press.

McNeill, W. (1983), The Pursuit of Power. Technology, Armed Force, and Society since A.D. 1000, Oxford: Basil Blackwell.

Meijer, M. (1994), 'Het komt telkens terug alsof het nieuw is', Elsevier, 26 maart 1994.

Olson, M. (1965), The Logic of Collective Action. Public Goods and the Theory of Groups, Cambridge: Harvard University Press.

Pick, D. (1993), War Machine. The Rationalization of Slaughter in the Modern Age, New Haven: Yale University Press.

Popper, K.R. (1945), The Open Society and Its Enemies, London: Routledge.

Popper, K.R. (1957), The Poverty of Historicism, London: Routledge.

Popper, K.R. (1972), Objective Knowledge. An Evolutionary Approach, Oxford: Oxford University Press.

Rijk, M. de (1986), 'Een socioloog wordt ook maar geleefd', NRC Handelsblad, 3 april 1986.

Swaan, A. de (1988), Zorg en de staat. Welzijn, onderwijs en gezondheidszorg in Europa en de Verenigde Staten in de nieuwe tijd, Amsterdam: Bert Bakker.

Thurlings, J. (1977), De wetenschap der samenleving. Een drieluik van de sociologie, Alphen aan den Rijn: Samsom.

Tromp, B. (1977), De samenleving als oplichterij. Opstellen over sociologie en politiek, Amsterdam: Synopsis.

Tromp, B. (2007), 'De nazi's als geslaagde socialisten', Vrij Nederland, 24 juli 2007.

Tulder, J. van (1962), De beroepsmobiliteit in Nederland 1919-1954. Een sociaalstatistische studie, Leiden: Stenfert Kroese.

Ultee, W., W. Arts en H. Flap (1992), Sociologie. Vragen, uitspraken, bevindingen, Groningen: Wolters.

Ultee, W. en H. Flap (1996), 'De Nederlandse paradox. Waarom overleefden zoveel Nederlandse joden de Tweede Wereldoorlog niet?', in: H. Ganzeboom en S. Lindenberg (red.), Verklarende sociologie. Opstellen voor Reinhard Wippler, Amsterdam: Thesis, p. 185-197. 
Ultee, W. en R. Luijkx (1998), 'De schaduw van een hand', in: H. Flap en W. Arts (red.), De organisatie van de bezetting, Amsterdam: Amsterdam University Press, p. 55-76.

Vlasblom, D. (2008), 'Een leven lang dwars', NRC Handelsblad, 17 mei 2008. Weber, M. (1920), Gesammelte Aufsätze zur Religionssoziologie, Tübingen: Mohr.

Weber, M. (1921), Wirtschaft und Gesellschaft, Tübingen: Mohr.

Wielek, H. (1947), De oorlog die Hitler won, Amsterdam: Amsterdamsche Boek- en Courantmij.

Wippler, R. (1978), 'The Structural-individualistic Approach in Dutch Sociology', Netherlands' Journal of Sociology 14: 135-155.

Wippler, R. (1983), 'Een model van oligarchiseringsprocessen in democratische organisaties', in: S. Lindenberg en F. Stokman (red.), Modellen in de sociologie. Bundel aangeboden aan prof. dr. I. Gadourek, Deventer: Van Loghum Slaterus, p. 40-61. 


\title{
4 Overzeese verkenningen op het grensvlak van geschiedenis en sociologie
}

\author{
Leonard Blussé
}

In het nagelaten werk van Jacques van Doorn neemt De laatste eeuw van Indië. Ontwikkeling en ondergang van een koloniaal project (1994) een bijzondere plaats in. Niet zozeer omdat Van Doorn, zoals hij zelf zei, heel tevreden was met dit boek, of omdat het uitmunt in analytisch inzicht en originele aanpak, maar vooral omdat deze studie nieuw licht heeft geworpen op de aard van de koloniale samenleving van Nederlands-Indië op een moment dat dit onderwerp eigenlijk uit de gratie was. Inmiddels staat de laatkoloniale staat en zijn nalatenschap weer in het middelpunt van de belangstelling. Daar heeft Van Doorns studie zeker toe bijgedragen.

In zijn bijdrage aan de studiedag in Breda betreurde Wout Ultee dat De laatste eeuw niet strakker in weberiaanse trant is geconcipieerd. De eerlijkheid gebiedt echter te vertellen dat het boek bestaat uit een bundel artikelen over een aantal vraagstukken uit de laatkoloniale samenleving waarover Van Doorn zich heeft gebogen. Tussen die vragen bestaat trouwens een duidelijk verband.

De laatste eeuw van Indië mag origineel van vraagstelling en inhoud zijn, het is wel een boek dat berust op onderzoek van anderen en gesprekken met anderen, en dan denk ik met name aan Wim Hendrix en Jan Breman met wie Van Doorn in Rotterdam jarenlang nauw heeft samengewerkt. Hendrix, wapenmakker op Java, en onderzoeksmedewerker van Van Doorn in Rotterdam, was in zekere zin de 'aangever' van het bronnenmateriaal. Van Doorn was zelf bepaald geen archiefvorser. Wat betreft zijn kennis van Indonesië leefde hij vrijwel in de Encyclopedie van Nederlands-Indië als je hem geloven mag. Ook Jan Breman heeft veel aan het voorbereidende werk van Hendrix te danken gehad bij het schrijven van zijn geruchtmakende studie over de misstanden in de plantagesamenleving van Noordoost-Sumatra aan het einde van de negentiende 
eeuw. De nauwe samenwerking tussen de hedgehog Hendrix en de twee foxes Van Doorn en Breman binnen het Comparative Asian Studies Program van de Erasmus Universiteit, heeft twee klassiekers in de laatkoloniale geschiedschrijving opgeleverd: Bremans Koelies, planters en koloniale politiek (1987) en Van Doorns De laatste eeuw (1994), studies die een helder licht werpen op twee interessante thema's, maar ook op de aard van de auteurs zelf: de scherp veroordelende en enigszins moraliserende Breman en de afstandelijk formulerende Van Doorn.

Het ligt voor de hand dat Bremans kritische studie Indonesiërs bijzonder aanspreekt. Zijn boek is dan ook zeer snel in het Engels, Chinees en Indonesisch vertaald. Van De laatste eeuw, een studie die in vele opzichten europacentrisch van aard is, valt zoiets niet te verwachten. Wat schetst mijn verbazing toen ik onlangs tijdens een werkcollege erachter kwam dat een groep Indonesische studenten met wie ik vorig jaar een hoofdstuk uit dit boek over 'Indië als koloniaal project' cursorisch gelezen had, de afgelopen maanden gezamenlijk het hele boek in het Indonesisch heeft vertaald, omdat de vraagstelling en de uitwerking daarvan hen zo bijzonder aanspraken. Dat zou Jacques goed gedaan hebben.

Was Van Doorn socioloog of historicus of is hier sprake van een socioloog die zich op het pad van de koloniale geschiedenis begeven heeft, zo vroeg Ultee zich in Breda af. Is hij wel echt als historicus te werk gegaan, berust zijn studie wel op grondig onderzoek in de archieven? Ter verduidelijking van zijn vraag lichtte Ultee toe dat zijns inziens de historicus iets uit het verleden probeert te verklaren, terwijl de socioloog verklaart naar het heden toe. Dat laatste heeft Van Doorn overigens nadrukkelijk gedaan in een ander boek met de veelzeggende titel Indische lessen. Nederland en de koloniale ervaring (1995) waarin hij zijn ideeën bundelde over het koloniale verleden. Hij stelde daarin vast dat de koloniale ervaring voor ons nog steeds van actueel belang is, omdat Nederland als koloniale mogendheid op geheel eigen wijze vorm probeerde te geven aan de multiculturele samenleving van Nederlands-Indië.

Voor de goede verstaander: een historicus hoeft niet noodzakelijkerwijs een archiefrat te zijn getuige de vermakelijke anekdote die de ronde deed begin jaren zeventig toen ik student was. De Leidse emeritus hoogleraar algemene geschiedenis, Bertus Schaper, en zijn opvolger Henk Wesseling waren op weg naar een bespreking in het Algemeen Rijksarchief dat zich toen nog op het Blijenburg in Den Haag bevond. De twee heren reisden vanuit Leiden niet naar Den Haag CS, maar naar Hollands Spoor en gingen vandaar te voet naar het archief om ten slotte al dwalende door de Hofstad erachter te komen dat geen van tweeën ooit het archief bezocht had en dus ook niet wist waar het was. Dit waren of zijn toch niet de minste historici. Waar het in de geschiedschrijving om gaat is het stellen van de juiste vraag en het formuleren van een antwoord daarop. Daar toonde Van Doorn zich een meester in. 
Van Doorn heeft als grondlegger van de beleidssociologie in Rotterdam goed zijn weg kunnen vinden in de vraagstukken van de laatkoloniale geschiedenis van Indonesië. Voortbordurend op het werk van historici als Maarten Kuitenbrouwer, Henk Wesseling, Cees Fasseur en Jur van Goor over het moderne imperialisme, Joep da Campo, de schrijver van het meesterwerk over de KPM, duizendpoot Han Baudet die onder meer in Balans van beleid (1961) op fascinerende wijze nog de denkbeelden van de laatkoloniale elite wist vast te leggen, de biografe van de ethische richting, Elsbeth Locher-Scholten en de militair historica Petra Groen constateert hij dat Nederlands-Indië als moderne koloniale staat eigenlijk maar een jaar of veertig bestaan heeft. De intrigerende stelling dat Nederlands-Indië een gigantisch ontwikkelingsproject was, is afkomstig van Henk Wesseling, maar Van Doorn heeft haar verder uitgewerkt. Hij heeft daar op zijn beurt weer anderen mee geïnspireerd, zoals Wim den Doel met zijn studie over het binnenlands bestuur, De stille macht (1994).

Waar kwam Van Doorns belangstelling voor Indonesië uit voort? Als dienstplichtig militair heeft hij tussen 1946 en 1950 op Java gediend en maakte daar, naar eigen zeggen, de meest interessante tijd van zijn leven mee. Een ervaring die hem een overvloed van materiaal verschafte, eerst voor zijn proefschrift over de militaire organisatie en later voor zijn samen met Wim Hendrix geschreven studies Ontsporing van geweld (1970) en Het Nederlands-Indonesisch conflict (1983) waarin thema's als excessen in oorlogstijd en het moeizame afscheid van Indië werden behandeld.

Het is al door Cor Lammers en anderen opgemerkt dat Van Doorn in de loop van zijn carrière niet meer geloofde in de sociologische wetenschap als een geïntegreerd wetenschapssysteem. Dat wil echter niet zeggen dat hij geen systematisch denker was. Elk hoofdstuk van De laatste eeuw representeert een helder omschreven paradigma, een vraag die een van de aandachtsgebieden van de sociologie bestrijkt en tegelijkertijd van historische betekenis is. Ik noem er enkele. De aard van de laatkoloniale maatschappij en de rol die de Nederlanders daarin speelden als maatschappelijke en culturele elite bij wie het bestuur, de exploitatie en de ontwikkeling van het wingewest berustte. In zijn studie over de verrichtingen van de Delftse ingenieurs op Java wijst hij op de triomf van de technocratie in de laatkoloniale staat. Aan de hand van de openlegging van de Preanger, de bergachtige landstreek bezuiden Jakarta, laat Van Doorn zien hoe daar aan het begin van de twintigste eeuw een markteconomie tot stand kwam. Daarbij passeren verschillende theorieën de revue: het dependencia-beginsel, de ideeën over de dualistische economische samenleving van J.H. Boeke, en de moderniseringsthese die stelt dat aansluiting tot de wereldmarkt bevrijding en individualisering zou moeten opleveren. Hij werkt een en ander verder uit door de theeregie van de Preanger nader te bezien, en stelt vast dat er sprake was van voort- 
durende interactie tussen 'de heren van de thee', de ondernemingen, en de kleine inheemse theeplanters van de kampongthee, en laat tegen de achtergrond van de werelddepressie van de jaren dertig zien hoe de exploitatiebelangen werden afgewogen tegen de volksbelangen.

Amusant is de constatering van Van Doorn dat hij nergens in de Encyclopedie van Nederlands-Indië iets kon vinden onder het kopje armoede (wel pauperisme maar dat betrof alleen de maatschappelijk afgezakte blanken en indo's). De Encyclopedie spreekt alleen van welvaart en 'mindere welvaart'. Kennen we die eufemismen niet nog steeds in onze socially engineered samenleving met zijn 'prachtwijken' van minister Vogelaar? Prachtwijken, krachtwijken. Er is niets nieuws onder de zon.

Waarom oefende Indië als koloniaal project zo'n bijzondere aantrekkingskracht op Van Doorn uit? Lammers merkt in zijn biografische notitie over Van Doorn op dat midden jaren tachtig Van Doorn eens verzuchtte dat ten gevolge van de vergaande de-institutionalisering van het maatschappelijk bestel de sociologie niet veel meer te bieden had. In de laatkoloniale tijd was het tegendeel het geval: daar was het nog institutionalisation galore. Nederlands-Indië was zoals Van Doorn (en Baudet voor hem) aantoonde een paradijs voor techneuten en ingenieurs. Je zou te midden van al het aanmodderen met de hogesnelheidslijn, de Betuwespoorweg en de Amsterdamse metro bijna vergeten dat de Nederlandse ingenieurs in Indië op technologisch gebied tot de koloniale wereldtop behoorden, toen de koloniale mogendheden aan het begin van de twintigste eeuw hun 'beschavingsoffensief' inzetten.

Een overmaat aan beleidsruimte gaf deze koloniale bestuurscultuur een modern activistisch en technocratisch stempel. En Van Doorn was er als de pieten bij om dat aan te duiden. Met indringende analyses laat hij zien hoe de infrastructuur in de tropische landbouw met zijn enorme irrigatie werkte, hoe spoorweg- en havenaanleg tot stand kwamen. Hij was voornamelijk geïnteresseerd in de politieke en constitutionele kaders waarin beslissingen over grote infrastructurele werken genomen werden. Hierbij was van groot belang - en hier citeer ik hem letterlijk - dat 'Het beheer en de ontwikkeling van het koloniale complex een zaak van de Nederlanders zijn geweest.' De kolonie was met de inheemse bevolking niet subject maar object, niet medespeler maar speelveld. Niets geen poldermodel, niets geen musyawarah of overlegcultuur waar president Soekarno prat op placht te gaan.

Cor Lammers heeft in zijn studie Vreemde overheersing onlangs ook nog geschreven over Nederland als bezettende macht. Hij gaat daar met name in op de collaboratie tussen overheerser en overheerste, een facet dat bij Van Doorn die een strikt europacentrisch perspectief hanteerde enigszins onderbelicht blijft. Van Doorn merkt op dat in NederlandsIndië alles in termen van projecten en stelsels plaatsvond. Vanaf de 
gouverneur-generaal Johannes van den Bosch (een oud-genieofficier) die aan het begin van de negentiende eeuw het Cultuurstelsel ontwierp tot het beschavingsoffensief van de ethische politiek in de twintigste eeuw. Van Doorn wijst in deze context op de spanningen binnen de ambtelijke hiërarchie van Nederlands-Indië tussen het binnenlands bestuur en hooggeschoolde specialisten uit Delft. Maar de alfa en de omega van het koloniaal bestuur is de eeuwige spanning tussen het privé-initiatief, het zakenleven, de planters en de overheid: het eeuwige touwtrekken, de tug of war tussen de kaders van de ambtelijke en de zogenaamde duitenhiërarchieën.

In De laatste eeuw van Indië (1994) draait eigenlijk alles om beleidsanalyse en contextualisering: hoe verliep het besluitvormingsproces op het hoogste niveau, aan wat voor situationele dwang stonden de actoren bloot? Wat waren de politieke en constitutionele kaders waarbinnen ze geacht werden te opereren? Dat waren prangende vraagstukken niet alleen tijdens de hoogtijdagen van het Nederlandse kolonialisme voor de oorlog, maar ook tijdens de politionele acties na de oorlog, toen beleidsmakers als Van Mook en Spoor en Schermerhorn onder invloed van ervaringen uit het verleden te maken kregen met institutionele overmacht en geen kant meer op konden in hun onderhandelingen. Zij bleken gevangen te zitten in vooroorlogse concepties die op het naoorlogse Indonesië werden geprojecteerd, zoals zekerheden over de blijvende band van Indië met het moederland, een multiraciale samenleving waarin plaats was voor Nederlanders, en een federale staatsstructuur waarin de macht over alle eilanden werd verdeeld. Maar in het denken van de Indonesische nationalisten was geen plaats voor sentimentele gevoelens als 'door de eeuwen trouw'. De plurale samenleving bleek niet anders dan een koloniale verdeel-en-heersconstructie te zijn en de federale staatsstructuur stond de eenheidsgedachte van de jonge republiek in de weg. De kolonisatie van Indië, zo zegt Jacques van Doorn, bleek uiteindelijk een fuik te zijn.

\section{Geraadpleegde literatuur}

Baudet, H. en I.J. Brugmans (red.) (1961), Balans van beleid. Terugblik op de laatste halve eeuw van Nederlandsch-Indië, Assen: Van Gorcum.

Breman, J. (1987), Koelies, planters en koloniale politiek. Het arbeidsregime op de grootlandbouwondernemingen aan Sumatra's Oostkust in het begin van de twintigste eeuw, Leiden: KITLV.

Doel, H.W. van den (1994), De stille macht. Het Europese binnenlandse bestuur op Java en Madoera 1808-1942, Amsterdam: Bert Bakker.

Doorn, J.A.A. van (1994), De laatste eeuw van Indië. Ontwikkeling en ondergang van een koloniaal project, Amsterdam: Bert Bakker. 
Doorn, J.A.A. van (1995), Indische lessen. Nederland en de koloniale ervaring, Amsterdam: Bert Bakker.

Doorn, J.A.A. van en W.J. Hendrix (1970), Ontsporing van geweld. Over het Nederlands/Indisch/Indonesisch conflict, Rotterdam: Universitaire Pers.

Lammers, C.J. (2005), Vreemde overheersing. Bezetten en bezetting in sociologisch perspectief, Amsterdam: Bert Bakker. 


\section{Deel III}

Beleidssocioloog en publiek socioloog 



\title{
$5 \quad$ Relativering van rationaliteit \\ Naar een reflexieve beleidssociologie
}

Romke van der Veen ${ }^{1}$

\begin{abstract}
Inleiding
'De' centrale figuur van de naoorlogse sociologie in Nederland, J.A.A. van Doorn, nam na zijn emeritaat in 1987 geleidelijk meer en meer afstand van de sociologie. Het proces van maatschappelijke individualisering verzwakte in zijn ogen de werking van belangrijke instituties die de basis vormen van de maatschappelijke orde. Deze afkalving van instituties als klasse, ideologie, religie of de rationele organisatie ondermijnde vervolgens de kracht van het sociologische verklaringsmodel waarin instituties immers centraal staan. Dit heeft tot gevolg dat de historiserende beschrijving en de sociaal-psychologische verklaring volgens Van Doorn belangrijker instrumenten worden voor de analyse van het sociale dan de sociologie. Terugkijkend op het - omvangrijke - werk dat hij na zijn emeritaat heeft gepubliceerd, kunnen we echter concluderen dat Van Doorn, zijns ondanks, vooral en bovenal een socioloog is gebleven. Ook in een meritocratische, postmaterialistische en seculiere samenleving is sociologische reflexiviteit, zoals die werd gepersonifieerd in Van Doorn, onmisbaar. De bundeling Nederlandse democratie. Historische en sociologische waarnemingen van verspreid werk van Van Doorn (2009) illustreert de hardnekkigheid van zijn sociologische blik. Alles, ook het sociaal-psychologische, wordt door hem geanalyseerd vanuit het sociale proces waarin het is geproduceerd. Dit is wellicht kenmerkender voor Van Doorns sociologische visie dan de verklarende rol van krachtige instituties: de sociale productie van het ogenschijnlijk individuele en het ogenschijnlijk unieke die maakt dat identiteiten en ervaringen in hoge mate gedeeld worden en dus sociologische categorieën zijn.

Hoewel Van Doorn als de wegbereider in Nederland van de professionele, academische sociologie wordt gezien, heeft hij de sociologie toch vooral als een naar buiten gerichte wetenschap bedreven. Hij schreef
\end{abstract}


niet primair voor zijn peers, maar was vooral een analyticus die de instrumenten van de sociologie gebruikte om de wereld om hem heen te duiden. Hij was niet primair gericht op het vooruitbrengen van het sociologische ambacht, maar vooral op het vergroten van het sociologische inzicht in maatschappelijke ontwikkelingen. In deze zin zette hij het programma van de grondleggers van de sociologie, en dan vooral van Max Weber, voort. Van Doorn bezag de wereld vanuit het perspectief van voortgaande rationalisering, waarbij hij zich vooral richtte op de wereld van politiek en beleid. Evenals Weber bezat hij een sterk besef van de waarde, maar ook van de ondermijnende werking van het proces van rationalisering.

De overeenkomst met Weber gaat nog verder. Van Doorns sociologische analyses zijn consequent historiserend opgezet. Dat geldt voor zijn vroege studies van industrialisering en de militaire organisatie (1956), maar ook voor zijn latere studies van de verzorgingsstaat $(1977,1978)$, het kolonialisme $(1973,1994)$, generaties (2002) en het Duits socialisme (2007). Deze historiserende aanpak maakte Van Doorn weinig gevoelig voor intellectuele modes. Niet zelden wees hij erop dat er weinig nieuws was onder de zon, zonder overigens in conservatief 'gemopper' te vervallen. Zijn historiserende analyses van bijvoorbeeld 'populisme' (Van Doorn 2009: 475-517) of 'de buurt als maatschappelijk integratiekader' (Van Doorn 2009: 90-116) gebruikte hij om de sociologische continuiteit en de intellectuele valkuilen die vaak onder actuele maatschappelijk discussies verborgen gaan, zichtbaar te maken.

Van Doorns naar buiten gerichte wijze van beoefenen van de sociologie heeft hem niet de weg naar de 'kunde' doen inslaan. Hij beschouwde zich als intellectueel niet als een 'vertegenwoordiger van de hogere wetgevende rede', maar als iemand die inzicht kon vergroten zonder voorschriften te geven. Sociologische theorie en historische analyse waren de instrumenten die hij gebruikte om dit inzicht te verwerven. Zijn besef van de grenzen van de rationaliteit en de disfuncties van rationalisering was groot genoeg om hem, na overigens eerst wel stappen in de richting van een toegepaste sociologiebeoefening te hebben gezet, te behoeden voor een instrumentele invulling van de sociologieopleiding en van de sociologische praktijk.

In deze bijdrage zal ik de ontwikkeling van Van Doorns denken over de bruikbaarheid van sociologische kennis en de toepassing van die kennis in een op het beleid gerichte sociologiebeoefening in kaart brengen.

\section{Relativering van rationaliteit}

De beleidswetenschap vormt een belangrijke verbindende schakel in het oeuvre van Van Doorn. De vraag wat voor hem een sociologische beleids- 
wetenschap was, hoe hij zich als beleidswetenschapper heeft ontwikkeld en welke lessen wij uit zijn Werdegang door de sociologische beleidswetenschap kunnen trekken staan centraal in deze beschouwing.

De grote reikwijdte van Van Doorns sociologische werk heeft hem zelf tot de volgende typering van zijn eigen werk gebracht: 'Er lijkt geen vaste lijn in te ontdekken, zelfs geen peil op te trekken.'2 Maar, hoewel Van Doorns studies zich bewegen van de proletarische achterhoede, via employés en arbeiders, naar de ontsporing van geweld en het nationaalsocialisme, doet hij zichzelf met deze uitspraak onrecht. Er is wel degelijk een duidelijk sociologisch thema in dit zo breed uitwaaierende oeuvre te ontdekken: de maatschappelijke functies en disfuncties van het rationele, construerende, organiserende en beleidsmatige. Een fascinatie voor de droom der rede, die later werd gecombineerd met de scepsis van de conservatieve intellectueel.

Deze rode draad door het oeuvre van Van Doorn is door hemzelf kernachtig samengevat in de titel van het boek Rede en macht (1988), een boek dat hij typeerde als een uitwerking van zijn afscheidscollege Relativering van rationaliteit (1987). De ondertitel van Rede en macht, Een inleiding tot beleidswetenschappelijk inzicht, had wellicht beter van een uitleiding kunnen spreken, omdat in het boek de ontwikkeling van het denken van een socioloog die immer met beide benen in het politieke en maatschappelijke debat stond, zichtbaar wordt. Een evolutie die tot relativering van rationaliteit leidde.

De rode draad door zijn werk, de wisselwerking tussen rede en macht, vormt voor hem ook de rode draad in de ontwikkeling van de moderne samenleving: voortgaande rationalisering van de samenleving en een streven naar beheersing van maatschappelijke ontwikkelingen. De wisselwerking tussen rede en macht is voor Van Doorn niet zonder risico. De rede bevrijdt weliswaar van willekeur, bijgeloof en toeval, maar terwijl mensen hun maatschappij maken voelen zij zich ook en wellicht steeds meer de gevangene van de uit het proces van rationalisering ontsproten instituties. Deze institutionele dwang kan vervolgens leiden tot een ontsporing van rationaliteit.

Met de oprichting van de Sociologische gids in 1953 en later met de met C.J. Lammers geschreven programmatische inleiding tot de Moderne sociologie (1959) stond Van Doorn aan de wieg van een 'waardevrije', dat wilde toen zeggen een niet-verzuilde sociologiebeoefening. De keuze voor een moderne, op het werk van Parsons, Merton en Lazarsfeld geïnspireerde sociologiebeoefening, vertegenwoordigde een breuk met de sterk beschrijvende en theoretisch arme sociografie waaruit de Nederlandse sociologie voortkwam. Continuïteit was er ook, met name in de op de praktijk gerichte sociologie die Van Doorn propageerde. Aanvankelijk als directeur van het ISONEVO, later vooral als bouwdecaan van de 
Rotterdamse sociale faculteit. In deze laatste functie gaf hij in de jaren zestig vorm aan een in zijn ogen op de praktijk gerichte, niet exclusief academische, sociologieopleiding. Een opleiding die sociologen vooral leerde zich te bewegen langs de as van wetenschap-werkelijkheid en veel minder langs de as van theorieonderzoek (Leune 1987: 10). Niet de opleiding van de wetenschappelijke socioloog stond hem voor ogen, maar die van de op de praktijk van beleid en organisatie gerichte socioloog wiens wetenschappelijke kennis ten dienste stond van praktisch handelen.

Als decaan stimuleerde Van Doorn nadrukkelijk de ontwikkeling van een praktische beleidssociologie, dat wil zeggen een sociologie die zich richt op het produceren van instrumentele kennis ten behoeve van een buiten de academie gesitueerd publiek. In zijn eigen werk was Van Doorn zich echter te sterk bewust van de grenzen van de rationaliteit en de verlokkingen van de macht om zich tot het ambacht van de instrumentele beleidssocioloog te beperken. Sterker nog: Van Doorn is eigenlijk nooit een echte instrumentele beleidssocioloog geweest. Van Doorns eigen werk is een mengeling van een historiserende, kritische sociologie met een in toenemende mate publieke sociologie. Een kritische sociologie produceert reflexieve kennis en richt zich hiermee primair op een academisch publiek en op het bespreken en vooral tegenspreken van de dominante onderzoeksprogramma's van de scientistische sociologie. Een publieke sociologie mengt zich in het publieke debat en tracht vooral de reflexiviteit van het publieke debat te verhogen.

Hoewel Van Doorn van mening was dat de sociologie als interventiewetenschap een bijdrage kon leveren aan de rationaliteit van beleid, richtte zijn eigen werk zich vooral op de irrationaliteit van het beleid. Dit laatste past ook beter bij de openlijk beleden, conservatieve intellectueel, die in zijn Rotterdamse diesrede in 1976, niet lang na de hoogtijdagen van de academische revolte, onder de titel Conservatieve gedachten (Van Doorn 1996: 212), het volgende schrijft:

Er is geen vliegtuigpassagier zo bang als een vliegtuigbouwer en niemand heeft meer vrees voor oorlog dan een militair. (...) Zo zal ook de beoefenaar van wetenschap, zeker indien zijn werk hem brengt op het gebied van de toepassing van wetenschappelijke kennis, zo al niet bang, dan toch bescheiden moeten zijn. Een door wetenschap beheerste wereld was ooit een utopie, het is thans een schrikbeeld. (...) Wetenschappelijke vooruitgang bestaat dan ook niet in het verifiëren van theorieën, maar in falsifiëren. (...) De enige verkieslijke maatschappelijke orde is dan die welke de discussie open houdt. 
Hoewel pleitbezorger van een sociology for policy, was Van Doorn zelf vooral een beoefenaar van de sociology of policy (cf. Leune 1987: 21). In zijn beschouwing over interventiewetenschap in Rede en macht spreekt Van Doorn over het ontstaan van een 'beleidsbestel': een beleidsdomein, als bijvoorbeeld de gezondheidszorg, wordt een beleidsbestel wanneer er sprake is van 'een rationeel systeem van gespecialiseerde, sterk technische verrichtingen, bestuurd vanuit een managementniveau waar bij voortduring kosten en baten worden afgewogen' (Van Doorn 1988: 178). En hoewel Van Doorn het nut van de interventiewetenschappelijke bijdrage aan de ontwikkeling van een dergelijk beleidsbestel niet bestrijdt, ligt voor hem het belang van de beleidssociologie toch elders (idem: 179):

Waar het op aankomt is vast te stellen waar de grenzen van de doelrationele potentie liggen en vooral, waar de pretentie van rationele oplossingen in botsing komt met concurrerende waarden en normen.

De beperking van de instrumentele beleidssociologie is voor Van Doorn daarom vooral gelegen in haar (te) sterke focus op beheersing. Het streven naar beheersing resulteert in het zoeken naar de meest rationele weg, die vervolgens in dwingende beleidsinstructies vertaald wordt. In de plaats van deze in uniformiteit resulterende beheersingsroute stelt hij een benadering gericht op concurrentie en variëteit. Van variatie democratie, decentralisatie, concurrentie - kan via selectie geleerd worden. In plaats van een conventionele, rationalistische beleidssociologie, bepleit Van Doorn (idem: 182) een meer kritische, theoretisch-reflexieve beleidssociologie:

Het wordt, kortom, tijd de conventionele interpretatie van beleid te verruilen voor, of in ieder geval aan te vullen met, meer sophisticated analyses. Het is al vaak gezegd: niets is zo praktisch als een goede theorie.

In zijn relativering van rationaliteit is Van Doorn, net als in de rest van zijn werk, een echte socioloog gebleven. De sociologische twijfel over de waarde en de mogelijkheid van rationaliteit en rationalisering is immers één van de bouwstenen van de sociologie sinds Weber.

\section{Een casus: de verzorgingsstaat}

In de jaren zeventig en tachtig publiceert Van Doorn een aantal beschouwingen over de moderne interventiestaat waarin hij de reflexieve beleidssociologie die hij propageert toepast. Deze beschouwingen verschijnen 
in het mede door hem opgerichte maandblad Beleid en maatschappij. In retrospectief illustreren deze beschouwingen de intellectuele kracht van Van Doorns reflexieve beleidssociologie. Met Kees Schuyt legt hij de basis voor de Nederlandse discussie over de verzorgingsstaat, in de bundel $D e$ stagnerende verzorgingsstaat (1978). De sociologie, die mede aan de wieg van de moderne, naoorlogse verzorgingsstaat stond, blijkt ook in staat kritisch naar haar eigen geesteskind te kijken. In de Nederlandse verzorgingsstaat zijn mechanismen aan het werk die tot een overvraging van beleid leiden (Van Doorn 1980) en de verzorgingsstaat onbeheersbaar (Van Doorn 1977) maken. Belangrijk hierin is volgens Van Doorn de rol van de confessionelen en de onbedoelde gevolgen van het Nederlandse corporatisme: 'baas in eigen huis en het huis ten laste van de gemeenschap', zoals hij het ooit treffend formuleerde (Van Doorn 1978).

De kern van het probleem van de stagnerende en onbeheersbare verzorgingsstaat is voor Van Doorn gelegen in de vervlechting tussen het maatschappelijke middenveld en de staat. Herziening van de verzorgingsstaat is voor hem dan ook vooral een proces van ontvlechting. Dit is niet een proces in de richting van minder staat of deregulering, zoals de in die tijd populaire oplossingen luidden, maar in de richting van een zwakkere vervlechtingsgraad en een krachtiger staatsoptreden (Van Doorn 1984a: 21):

Wie hieruit concludeert tot een verzwakking van de staat, en tot een 'zwakke' staat die in de plaats komt van een 'sterke', mist volledig de portee van wat zich momenteel afspeelt (...) de huidige operatie (...) vereist een zeer krachtige politieke koers.

Van Doorns analyse was zijn tijd vooruit. Hij was in tegenspraak met het dominante maatschappelijke discours dat was getoonzet in termen van deregulering, terugtred en ontmanteling. Het duurde nog zeker een decennium voordat Van Doorns analyse van de oorzaak van de problemen, de vervlechting tussen staat en maatschappij, gemeengoed werd. Dat gebeurde met de parlementaire enquête naar de uitvoeringsorganen voor de sociale verzekeringen in 1993. De problemen met de sociale zekerheid - misbruik en onbeheersbaarheid - werden in dit onderzoek in verband gebracht met de rol van de sociale partners in de uitvoering van de sociale zekerheid en het gebrek aan sturing en toezicht door de staat. Zijn conclusie dat ontvlechting een krachtiger staatsoptreden vereist is nog steeds omstreden. We kunnen echter dagelijks getuige zijn van deze politieke en beleidsmatige onvermijdelijkheid: daar waar de staat verantwoordelijkheden 'teruggeeft' aan maatschappelijke actoren gaat dat meestal gepaard met een intensivering van het toezicht en van de aansturing. 


\section{Beleidswetenschap}

Na de voorgaande beschrijving van Van Doorns ontwikkeling als socioloog wordt het tijd om de laatste opgeworpen vraag, welke lessen we kunnen trekken uit Van Doorns omgang met de sociologische beleidswetenschap, te beantwoorden. De belangrijkste les betreft de beperktheid van het rationele model van beleidswetenschap. In dit model zijn het identificeren van een probleem, het kiezen van doelen, het afwegen van interventiestrategieën en het evalueren van beleid, stappen die op basis van kennis en niet op basis van voorkeuren gezet worden. Beleid is echter wellicht in laatste instantie een rationeel, door kennis gestuurd project. Beleid krijgt vorm binnen de normatieve grenzen van de democratische rechtsstaat, is altijd een strijd tussen normen en feiten, en is ook en vooral mensenwerk.

Om met het laatste te beginnen: de werking van beleid is in hoge mate afhankelijk van processen van anticipatie door en interactie met de vele maatschappelijke actoren die bij het beleid zijn betrokken. Actoren anticiperen en reageren op beleid. Deze reflexiviteit van maatschappelijke actoren zorgt voor talloze onvoorziene, onbedoelde en soms averechtse effecten, omdat de anticipaties en reacties van actoren vaker niet dan wel in lijn zijn met de doelstellingen van het beleid. Van Doorns interventiewetenschappelijke analyse van de problemen van de moderne verzorgingsstaat is hiervan een treffende illustratie. Het reflexieve karakter van beleid maakt dat de beleidssociologie vooral de onbedoelde en soms averechtse gevolgen van beleid helpt begrijpen, maar veel minder handvaten geeft om beleidsmatig in te grijpen in maatschappelijke processen.

De gegevenheid dat beleid maken en beleid uitvoeren geen rationele, instrumentele bezigheden zijn, maakt dat de sociologische beleidswetenschap van Van Doorn een open oog heeft voor de, vaak impliciete, normatieve dimensie van beleidsinterventie en beleidswetenschap. Het beleidsproces is ook en vooral keuzes maken. Dit wordt zichtbaar in de beleidsdoelen, maar ook in de uitvoering van beleid.

Beleidsdoelen zijn bijna per definitie niet eenduidig. Beleidsdoelen grijpen immers vaak terug op fundamentele noties over rechtvaardigheid, efficiëntie, veiligheid en vrijheid. Deze algemene noties, die velen zullen onderschrijven, moeten niet alleen de gemaakte beleidskeuzes legitimeren, ze geven ook criteria voor evaluatie. Het probleem is echter dat deze noties ambigu zijn, dus interpretatieproblemen met zich meebrengen, en vaak ook onderling tegenstrijdig kunnen zijn. Er vindt vaak een trade-off tussen de verschillende noties plaats, denk aan de dilemma's van milieu en economie, van rechtvaardigheid en efficiëntie. De roep om eenduidige en heldere doelen, die niet alleen afkomstig is van ambtenaren en politici maar ook van bij het beleid betrokken interven- 
tiewetenschappers - sociologen, bestuurskundigen, juristen en economen - is een echo van het rationele model van beleid, die in de praktijk zelden zal kunnen worden gehonoreerd.

84 De normatieve dimensie van beleid wordt ook zichtbaar in de uitvoering. Uitvoeren van beleid is niet zozeer het instrumenteel ten uitvoer leggen van door de beleidsmaker vastgestelde doelen, maar veel meer het kiezen van een haalbare en uitvoerbare toepassing van deze doelen. In de confrontatie met de complexe en veelvormige alledaagse werkelijkheid van bijvoorbeeld het vreemdelingenbeleid, het landbouwbeleid of het veiligheidsbeleid versnipperen op het eerste gezicht heldere doelstellingen tot talloze uitvoeringsproblemen waaruit de uitvoerder zich een weg moet kiezen.

Dit stelt de roep om heldere, uitvoerbare en handhaafbare regels in een ander licht. Van Doorn trok hieruit de conclusie dat de beleidswetenschap zich niet moet richten op het formuleren van uniformerende en wetenschappelijk gefundeerde voorschriften, maar vooral op het bevorderen van variatie en concurrentie (Van Doorn 1988). Tegenwoordig zouden we zeggen dat de beleidswetenschap 'beleidsleren' moet ondersteunen en dat doe je door variatie te stimuleren. Alleen zo kun je leren van fouten. De beleidswetenschap vergroot zo de kennis over het beleid zonder de zekerheid hoe beleid gevoerd moet worden direct te vergroten.

In het rationele model van beleidswetenschap is deze wetenschap ook behulpzaam bij het vormgeven en evalueren van beleid. Ook deze stappen zijn niet altijd gebaseerd op rationele berekening en weging. We moeten opties kunnen benoemen en alternatieven kunnen wegen, oorzaken en gevolgen kunnen aanwijzen. In al deze processen spelen classificaties, het benoemen van verschijnselen, een beslissende en onvermijdelijke rol (vergelijk Van Doorn 1986). Classificaties zijn echter constructies, geen feitelijke waarheden. Classificaties delen een continue werkelijkheid op in discrete eenheden. Beleidsdebatten en ook uitvoeringsvragen zijn daarom vaak debatten over gelijkheid en verschil. Is een foetus een mens? Is een foetus ouder dan twaalf weken een mens? Wanneer gaat coma over in hersendood? Of uit andere domeinen dan de medische ethiek: wat is een vluchteling en wanneer kunnen we spreken over een economisch gemotiveerde asielzoeker? Wanneer is sprake van aanvaardbare veiligheidsrisico's? Wanneer is sprake van uitstroom uit gesubsidieerde arbeid? Classificatieproblemen, en die doen zich eigenlijk altijd voor, zorgen er voor dat de problemen die we tegenkomen bij het vaststellen van doelen zich herhalen op het niveau van de uitvoering, en vervolgens ook bij de vormgeving en de evaluatie van beleid.

De les die ik uit deze, vooral sociologische visie op beleid trek is dat het beoefenen van interventiewetenschap, ondanks alle problemen die 
eraan kleven, meer is dan het vertellen van verhalen, de postmoderne variant, of meerijden op de stoel van de beleidsmaker, de beleids- of bestuurskundige variant. De sociologische beleidswetenschap kan een belangrijke bijdrage leveren aan beleidsinterventies in het maatschappelijk verkeer door een waarheidszoekende en een oriënterende functie ${ }^{3}$ te combineren. De eerste dwingt tot zorgvuldige, methodisch verantwoorde empirische analyse. De tweede tot een zorgvuldige doordenking van theoretische en normatieve perspectieven op maatschappelijke en beleidsproblemen en de mogelijke wijzen van omgaan met deze problemen.

\section{Noten}

1. Dit hoofdstuk is een uitwerking van een artikel in Sociologie (Van der Veen 2008).

2. Aangehaald in: De draagbare Van Doorn (1996).

3. Het onderscheid tussen de waarheidszoekende en de oriënterende functie in deze vorm is geïntroduceerd door Kees Schuyt (1986: 9-36).

\section{Geraadpleegde literatuur}

Doorn, J.A.A. van (1956), Een sociologische benadering van het organisatieverschijnsel in het bijzonder gebaseerd op een analyse van de militaire organisatie, Leiden: Stenfert Kroese.

Doorn, J.A.A. van (1973), Orde-opstand-orde. Notities over Indonesië, Meppel: Boom.

Doorn, J.A.A. van (1977), 'De beheersbaarheid van de verzorgingsmaatschappij', Beleid en maatschappij 4: 115-128.

Doorn, J.A.A. van (1978), 'De verzorgingsmaatschappij in de praktijk', in: J.A.A. van Doorn en C.J.M. Schuyt (red.), De stagnerende verzorgingsstaat, Amsterdam: Boom, p. 17-46.

Doorn, J.A.A. van (1980), 'Overvraging van beleid', Beleid en maatschappij 7: 39-49.

Doorn, J.A.A. van (1984a), 'Anatomie van de interventiestaat', in: J.W. de Beus en J.A.A. van Doorn (red.), De interventiestaat. Tradities, ervaringen, reacties, Meppel: Boom, p. 9-24.

Doorn, J.A.A. van (1984b), 'De onvermijdelijke presentie van de confessionelen', in: J.W. de Beus en J.A.A. van Doorn (red.), De interventiestaat. Tradities, ervaringen, reacties, Meppel: Boom, p. 27-51.

Doorn, J.A.A. van (1986), 'Classificatie en maatschappij', in: J.W. de Beus en J.A.A. van Doorn (red.), De geconstrueerde samenleving. Vormen en gevolgen van classificerend beleid, Meppel: Boom, p. 29-48.

Doorn, J.A.A. van (1988), Rede en macht. Een inleiding tot beleidswetenschappelijk inzicht, 's-Gravenhage: VUGA. 
Doorn, J.A.A. van (1994), De laatste eeuw van Indië. Ontwikkeling en ondergang van een koloniaal project, Amsterdam: Bert Bakker.

Doorn, J.A.A. van (1996), De draagbare Van Doorn, Amsterdam: Prometheus.

Doorn, J.A.A. van (2002), Gevangen in de tijd. Over generaties en hun geschiedenis, Amsterdam: Boom.

Doorn, J.A.A. van (2007), Duits socialisme. Het falen van de sociaal-democratie en de triomf van het nationaal-socialisme, Amsterdam: Mets \& Schilt.

Doorn, J.A.A. van (2009), Nederlandse democratie. Historische en sociologische waarnemingen, Amsterdam: Mets \& Schilt.

Leune, J.M.G. (1987), 'Van Doorn en de sociologieopleiding in Rotterdam', in: J. Berting, J. Breman en P.B. Lehning (red.), Mensen, macht en maatschappij. Een bundel sociaal-wetenschappelijke opstellen, Amsterdam/Meppel: Boom, p. 10-31.

Schuyt, C.J.M. (1986), Filosofie van de sociale wetenschappen, Leiden: Martinus Nijhoff.

Veen, R. van der (2008), 'Tussen rede en macht: Naar een reflexieve beleidssociologie', Sociologie 4: 412-418. 


\title{
6 Een paar apart \\ Fortuyn en Van Doorn als publieke sociologen
}

\author{
Dick Pels
}

Vaak klaagt men dat academische sociologen met hun rug naar hun onderwerp, de Nederlandse samenleving, zijn gaan staan, onder dwang van het Angelsaksische prestatiemodel en de noodzaak van het publiceren in Engelstalige refereed journals. Desondanks zijn sociologen nog steeds verrassend sterk aanwezig in het landelijke publieke en politieke debat. Academici als Godfried Engbersen, Gabriël van den Brink, Evelien Tonkens en Willem Schinkel niet te na gesproken, lijken dat echter minder degenen te zijn die genieten van een vaste universitaire betrekking dan degenen die een zekere afstand hebben genomen van het academisch bedrijf, zoals emeriti of freelancepublicisten. Is die relatieve marginaliteit voor sociologen tegenwoordig een voorwaarde om hun verbeeldingskracht te laten spreken en een effectieve publieke rol te spelen?

In plaats van me te wagen aan een complete sociologie van het intellectuele veld, wil ik die vraag in beperkter zin beantwoorden door twee sociologen te vergelijken die in het publieke debat vanaf de politieke scharnierjaren 2001-2002 een zeer zichtbare rol hebben gespeeld: Pim Fortuyn en Jacques van Doorn. Het is een paar apart, en minstens één van hen zal zich vanwege die vergelijking wellicht in zijn graf omdraaien. Zo zou Van Doorn Fortuyn het liefst de eretitel van socioloog en intellectueel hebben willen onthouden. Maar het is niet te veel gezegd dat ze in intellectueel-politiek opzicht belangrijke tegenpolen zijn geworden. Preciezer geformuleerd: Van Doorn oefende tijdens Fortuyns korte politieke leven felle kritiek uit op diens denkbeelden en stijl van optreden, en ontpopte zich na de moord tot de meest vocale tegenspreker van zijn populistische nazaten en zijn partij- en mediapolitieke erfenis. Hun levenstrajecten zijn bovendien in zoverre vergelijkbaar dat zij rond hetzelfde jaar (1987-1988) de academie verlieten: Van Doorn als 62-jarige emeritus, Fortuyn als 40-jarige freelancer, om pas daarna hun roeping als publieke en politieke intellectueel te vinden. 
Wellicht kan uit deze vergelijking iets belangwekkends worden afgeleid omtrent de materiële, pragmatische of sociologische voorwaarden voor buitenstaanderschap, dissidentie en tegendraadsheid: eigenschappen die vaak als wezenskenmerken van de kritische intellectuele positie worden genoemd. Speciale aandacht gaat daarbij uit naar het effect van institutionele grenzen en grensoverschrijdingen, zowel in tijdelijke als permanente zin, tussen universiteit en buitenwereld. Als achtergrond voor deze overwegingen gebruik ik (een vertaling van) het schema dat is opgesteld door de Amerikaanse socioloog Michael Burawoy (2005) in zijn bekende pleidooi voor een publieke sociologie (figuur 2).

Figuur 2 Verdeling van de sociologische arbeid

\begin{tabular}{|l|l|l|}
\hline & Academisch publiek & Buiten-academisch publiek \\
\hline Instrumentele kennis & Professionele sociologie & Beleidssociologie \\
\hline Reflexieve kennis & Kritische sociologie & Publieke sociologie \\
\hline
\end{tabular}

Burawoy schetst een verdeling van de sociologische arbeid in vier velden of domeinen: dat van de professionele sociologie, de beleidssociologie, de kritische sociologie en de publieke sociologie. Die arbeidsdeling is tegelijkertijd een constellatie van rivaliteiten: de vier domeinen hanteren verschillende, onderling concurrerende perspectieven op wat de sociologie is en moet zijn. Maar ze overlappen elkaar ook deels en werken samen; tal van beroepsbeoefenaars combineren elementen uit verschillende domeinen, of verleggen hun werkzaamheid gedurende hun carrière van het ene naar het andere domein. Terwijl professionele sociologen vooral in gesprek zijn met vakgenoten, voeren publieke sociologen vooral conversaties met buitenacademische publieken.

In de afgelopen decennia kunnen we volgens Burawoy een tendens waarnemen naar verzwaring van het soortelijk gewicht, de status en de financiering, dus naar machtstoename van de professionele sociologie (als gevolg van een 'industrialisering van de wetenschappelijke arbeid'), die de speelruimte van vooral de kritische en de publieke sociologie in toenemende mate onder druk heeft gezet. Burawoy onderscheidt vervolgens tussen een 'traditionele', binnenacademische variant van publieke sociologie (met voorbeelden als C. Wright Mills, Anthony Giddens en Pierre Bourdieu) en een 'organische', buitenacademische variant, waarbij sociologen in het voetspoor van de marxist Antonio Gramsci treden en figureren als wetenschappelijke adviseurs en intellectuele activisten in oude en nieuwe sociale bewegingen. 
Maar dit laatste onderscheid lijkt mij in drie opzichten problematisch. Ten eerste loopt de 'organische' socioloog het klassieke gevaar van populisme, dat wil zeggen van overidentificatie met het door hem gekozen publiek (bijvoorbeeld arbeiders, vrouwen of etnische minderheden). Ten tweede biedt het schema nauwelijks plaats aan degenen die zich aan het onderscheid onttrekken (die 'op de diagonaal zitten') en zich kritisch verhouden tot zowel de academisch verankerde als de buitenacademische publieke sociologie. Dat zijn de mavericks, de dropouts (inclusief degenen die met vervroegd pensioen zijn gegaan), de daadwerkelijk 'vrijzwevende' intellectuelen: freelancers die losvast zijn verbonden aan kranten, bladen, websites of denktanks en opereren als betrekkelijke eenlingen in het lezingencircuit en de opiniërende journalistiek. Het zijn éénpitters op de markt van meningen, die zich ophouden in niet sterk geïnstitutionaliseerde professionele niches, en die geen bestaande publieken bedienen maar eerder hun eigen publiek creëren. Ten derde vertoont Burawoys schema een pregnante linkse bias: zowel de traditionele als de organische publieke sociologen zijn sociaal-democraten of 'erger' links georiënteerd. Waar vinden we de rechtse of neoconservatieve sociologen of intellectuelen? Of zijn sociologen per definitie linksprogressief, en mogen rechtse sociologen dus geen sociologen heten? Waar plaats je rechtse populisten die zich beschouwen als organische intellectuelen van de natie?

Figuur 3 Publieke sociologie: kennis van/voor wie?

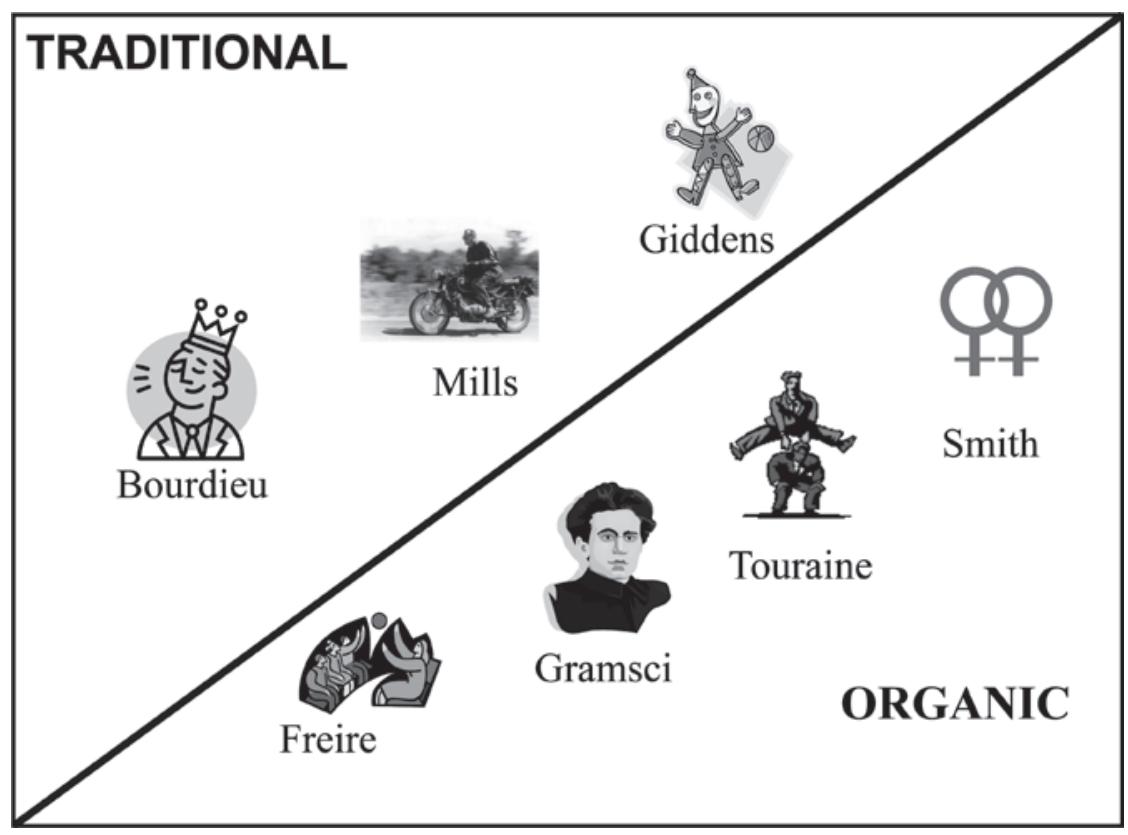


Noch Jacques van Doorn noch Pim Fortuyn passen daarom goed in het 'publieke' vakje van Burawoys 2x2-tabel. Wél kan die tabel behulpzaam zijn om in sneltreinvaart de intellectuele en beroepstrajecten van beide te schetsen. Zo lijkt Van Doorn alle vier de vakjes te hebben ingevuld, in een trage S-bocht door Burawoys schema. De grondvesting van de 'moderne' sociologie in de jaren vijftig kan worden gezien als zijn belangrijkste bijdrage aan de professionele sociologie. De ontwikkeling van het Rotterdamse programma (de 'Rotterdamse formule') en de oprichting van het tijdschrift Beleid en maatschappij in 1973 markeren een wending naar de beleidssociologie. Maar dat was geen beleidsgerichte sociologie in strikte zin, maar eerder een onderzoek naar de interdisciplinaire grondslagen van beleid dat uitdrukkelijk gericht was op de publieke zaak. Die kritische en reflexieve inslag wordt het duidelijkst zichtbaar in Van Doorns boek Rede en macht uit 1988, dat verschijnt op de grens van zijn emeritaat.

Uiteindelijk onttrekt Van Doorn zich echter als typische 'eenling' aan Burawoys schematisering, zeker in zijn laatste periode als onafhankelijk publiek socioloog. Ook volgens eigen zeggen was Van Doorn altijd 'zijn eigen man', een verzamelaar van grensgangerschappen (zoals wordt onderstreept in de inleiding van zijn postume bundel Nederlandse democratie, Van Doorn 2009), een sociologische en historische autodidact en een spijtoptant van het door hemzelf geïntroduceerde geloof in een 'moderne' vakmatige sociologie. Vanaf 1982 was hij actief als columnist (onregelmatig al vanaf 1975, dus zijn loopbaan als 'commentaarsocioloog' is in feite ongeveer even lang als zijn academische loopbaan). Ook qua persoonlijkheid straalde Van Doorn een vriendelijke afstandelijkheid en gereserveerdheid uit, die in fel contrast stond met - in de perceptie van Van Doorn - Fortuyns aanstootgevende exuberantie.

Opvallend genoeg heeft Fortuyn in grote lijnen een vergelijkbaar traject afgelegd. Begonnen als professionele arbeids- en beleidssocioloog stond hij als marxist echter van meet af aan dichter bij de kritische sociologie en het reflexieve grondslagendebat. Hij stapte eerder in zijn loopbaan uit de academie, betrad eerder de publieke sfeer en omarmde eerder het politieke columnisme. Fortuyn was vergeleken met Van Doorn natuurlijk ook veel bewuster en systematischer op zoek naar een rol in de 'grote' politiek. En toegegeven: zijn intellectueel-sociologische bijdragen werden na zijn vertrek uit de academie steeds 'dunner' en sloganachtiger, en kunnen nauwelijks in de schaduw staan van die van Van Doorn, die ook als columnist een indrukwekkende historisch-sociologische eruditie bleef tentoonspreiden. Maar het blijft intrigerend dat beide moeilijk zijn te plaatsen in een eenvoudig links-rechtsspectrum. In de reacties op het overlijden van Van Doorn hoorde men evenveel linkse (Bram Peper, Sjoerd de Jong, Jos de Beus) als rechtse stemmen (Gerry van der List, Dirk-Jan van Baar, Bart Jan Spruyt). Van Doorn was een zelfver- 
klaarde conservatief, maar zijn conservatisme was van een soort dat ook weldenkende linkse mensen van harte kunnen onderschrijven.

Fortuyn was op zijn beurt een politieke zwerfkat die van links kwam en op rechts eindigde, en mede daardoor moeilijk plaatsbaar bleef volgens traditionele politieke categorieën. Hij nam graag de dramatische pose aan van de 'eeuwige vreemdeling', van 'er niet bij (willen) horen' als levenslot en romantisch verlangen, en dat sentiment had natuurlijk een existentiële grond in zijn homoseksualiteit. Eén van zijn oneliners luidde: 'echte vernieuwing komt alleen uit de marge' (hij doelde daarbij vooral op zichzelf). Al zijn sociologisch geïnspireerde analyses (van de arbeidsmarkt, de overlegeconomie, de cultuur, de partijenpolitiek, de linkse kerk en de eliteheerschappij van Ons Soort Mensen) werden gedomineerd door de aan Norbert Elias ontleende grondgedachte van het 'grote gevecht' tussen de gevestigden en de buitenstaanders (waarin Fortuyn zelf natuurlijk figureerde als Buitenstaander No. 1).

Over dit ook door Fortuyn gesignaleerde verband tussen marginaliteit en intellectuele creativiteit is veel romantische onzin verkocht. Maar de metaforische samenhang tussen het beeld van de intellectueel en dat van de vreemdeling of buitenstaander heeft niet voor niets een lange geschiedenis in het sociale en politieke denken. Denk aan het adagium van socialistisch buitenbeentje Georges Sorel: il faut être en dehors pour bien voir. Die gedachte keert voortdurend terug: in Georg Simmels sociologie van de vreemdeling, in Karl Mannheims theorie van de freischwebende Intelligenz, in Edward Saïds definitie van de intellectueel als banneling, en in het 'nomadische denken' van postmoderne filosofen als Michel Foucault en Gilles Deleuze. Bij nadere beschouwing gaat het echter vaak om een elite van min of meer (academisch) gevestigden die zich als buitenstaander voordoen (intellectuele bourgeois die poseren als bohémiens), dus om een vorm van zelffelicitatie die beter 'nomadisch narcisme' kan heten (zie verder Pels 200o).

Want intellectuelen zijn niet intrinsiek kritisch. Dat is een vorm van essentialisme die zeker niet van toepassing is op de sociologie als professionele onderneming. Ik ben het dan ook oneens met Willem Schinkels opvatting dat 'in principe sociologie dus altijd een subversieve activiteit' is. Dat is op zijn best een vorm van wishful thinking, in het licht van de bekende processen van professionalisering, specialisering, academisering en bureaucratisering die Burawoy de 'industrialisering van de wetenschappelijke arbeid' noemt, en die Zygmunt Bauman eerder heeft aangeduid als de 'neolitische revolutie van de intellectuelen'. Sociologen maken onmiskenbaar deel uit van de elites van de kennismaatschappij.

Daarom is het enigszins plausibel dat diepgravende maatschappijkritiek niet gemakkelijk meer in en vanuit de geprofessionaliseerde 
academie kan worden geleverd. De romantische logica van het buitenstaanderschap kan beter worden omgekeerd. Anders gezegd, er is een verdubbeling nodig van de vervreemdingstheorie: we moeten letten op de marges van de marge, op de vrijzwevende intelligentsia binnen de vrijzwevende intelligentsia, op de grensgangers en over-de-grensgangers van de vrijplaats die de academie idealiter zou moeten zijn, maar niet meer is (of in onvoldoende mate). Freelancers en andere buitenstaanders zijn noodgedwongen non-conformisten die volgens de wetten van de gesitueerde kennis en het beroepsbelang niet per se beter of meer zien (het universele, de totaliteit); maar zij zien wél andere dingen, of dezelfde dingen op een andere manier, dan degenen die 'binnen' zijn. En natuurlijk past hierbij een reflexieve disclaimer: omdat 'het oog altijd wegkijkt van zichzelf', blijven buitenstaanders op hun beurt relatief blind voor hun eigen positie en de daarmee samenhangende belangen en 'zichtlijnen'.

Misschien komen we een stapje verder met de analyse van het 'veld' van de Nederlandse publieke sociologie aan de hand van Van Doorns Antwerpse oratie uit 1994 De intellectueel als ideoloog. Kritiek van de politieke intelligentsia, die ook is opgenomen in Nederlandse democratie (2009). Van Doorn beschrijft daarin het intellectuele en morele bankroet van de (linkse) politieke intelligentsia na de val van de Muur. Zij beging de fatale vergissing om te geloven in een seculiere God Die Faalde: die van het communisme. Die vergissing is vergelijkbaar met (en herhaalde) die van de rechtse intelligentsia die zich eerder had verbonden met het fascisme en nationaal-socialisme. Links bleek net zo vatbaar voor de totalitaire verleiding als rechts, en het is een historisch toeval dat de linkse intellectuelen er per saldo zo goed vanaf zijn gekomen.

Het is dus volgens Van Doorn een misverstand dat intellectuelen een 'natuurlijke afwijking' vertonen naar links: in werkelijkheid hebben zij iedere grote politieke beweging gediend. Dat de intellectuelen niet langer kunnen poseren als 'meesters van waarheid en rechtvaardigheid' (in de uitdrukking van Foucault) betekent niet dat zij in de politiek geen functie meer kunnen vervullen. Wél betekent het dat zij niet langer kunnen poseren als hoge vertegenwoordigers van de wetgevende rede, die de ervaringswijsheid van de gemiddelde burger bij voorbaat afdoen als een manifestatie van bevooroordeeldheid, onbegrip en onwetendheid. Alleen dan is er een verzoening mogelijk met de ongeordendheid en onoverzichtelijkheid die nu eenmaal kenmerkend zijn voor een democratische samenleving. 'Democratie is de politiek van het menselijk tekort', aldus de slotzin die de kern van Van Doorns conservatisme nog eens samenvat.

Dat was in 1994. Sindsdien zijn we getuige geweest van een soort return of the repressed. In Nederland is er sinds 2002 (in de VS al veel langer) 
sprake van de vorming van een nieuwe, luidruchtige falanx van rechtse of conservatief-liberale intellectuelen. De opkomst van deze intellectuele groepering is het belangrijkste nieuwe fenomeen in het veld van het publieke debat sinds 2002, met name in Nederland, waar de 'linkse kerk' lang domineerde en rechts-nationalistische denkbeelden vanaf het oorlogseinde min of meer taboe zijn gebleven. De socioloog Fortuyn kan worden gezien als de voornaamste voorganger en gangmaker van deze nieuwe intellectuele groepering. Zijn voornaamste verdienste is dat hij het publieke debat 'naar rechts' uitbreidde, naar thema's als immigratie, integratie en nationalisme, en het daarmee opnieuw in zijn volle breedte herstelde.

De kring omvat filosofen als Andreas Kinneging, Paul Cliteur en Ad Verbrugge, historici als Bart Jan Spruyt en Joshua Livestro, literatoren als Leon de Winter, cineasten als (wijlen) Theo van Gogh, arabisten als Hans Jansen en journalisten als Theodor Holman, Gerry van der List, Sylvain Ephimenco en Max Pam. Daarnaast is er het geheel eigen geluid van de Britse ex-psychiater Theodore Dalrymple. Zij bewegen zich in een archipel van publicatiefora en organisaties, die onderling een losse samenhang vertonen: de neoconservatieve Burke Stichting, HP/De Tijd onder Henk Steenhuis, Trouw/Letter en geest tot 2006 (Jaffe Vink, Chris Rutenfrans), daarna het weekblad Opinio (januari 2007-juni 2008) en tegenwoordig de opiniepagina van de Volkskrant, Elsevier (de columns van Van der List en Spruyt, eerder die van Fortuyn en De Winter), het weblog GeenStijl, De Telegraaf en zijn nieuwe omroep Wakker Nederland. Die laatste wil de 'conservatief-liberale stroming' in Nederland een stem geven. Maar dat programma kan in feite worden gezien als de missie van de gehele groep.

In deze kring kunnen twee ideologische kernen worden onderscheiden: die van militante secularisten en atheïsten zoals Paul Cliteur, Afshin Ellian en Herman Philipse, die zweren bij het verlichtingsrationalisme, en die van meer christelijk geïnspireerden als Bart Jan Spruyt, Andreas Kinneging en Ad Verbrugge, die vasthouden aan de superioriteit van 'onze' joods-christelijke cultuur. Tezamen zorgen zij voor een intrigerende ideologische convergentie tussen het marktliberalisme en het neoconservatisme die nieuw is in het Nederlandse politieke landschap. Het 'gedachtegoed' van Fortuyn kan worden gezien als een eclectische voorbode van die ideologische fusie. Het conservatief manifest van de Burke Stichting uit oktober 2003 bepleitte met zoveel woorden het samengaan van een 'authentiek' conservatisme (waar het CDA zich niet aan zou durven wagen) met een 'klassiek' liberalisme (dat een stuk radicaler was dan dat van de VVD). Na dit manifest ontpopte mede-auteur Spruyt zich als ghostwriter van de afgescheiden VVD'er Geert Wilders, en legde vergelijkbare denkbeelden neer in diens Onafhankelijkheidsverklaring (2005) en het programmastuk Klare wijn (2006). 
De denkbeelden van de meer populistische van deze intellectuelen lijken in sommige opzichten op die van de radicale völkische cultuurnationalisten van de Conservatieve Revolutie tijdens de Weimarrepubliek. Maar de moderne volksdenkers denken in een geheel nieuwe naoorlogse politieke en culturele constellatie: binnen (en niet buiten) de kaders van de bestaande liberale vertegenwoordigende democratie, terwijl eerdere 'revolutionairen van rechts' deze juist radicaal wilden afschaffen. Daarnaast opereren zij binnen (en niet buiten) de kaders van het neoliberale kapitalisme, terwijl de volksdenkers uit de jaren twintig en dertig nog een soort (namelijk nationale) socialisten waren (een ongemakkelijk feit dat Van Doorn nogmaals magistraal uitdiept in zijn laatste boek Duits socialisme). Bovendien bewegen moderne Europese neonationalisten en neopopulisten zich binnen het totaal gewijzigde kader van de Europese eenwording, waarvan zij de voortgang proberen af te remmen. Vanwege deze en andere redenen kan het moderne populisme niet worden afgedaan als een ongelukkig politiek incident, maar moeten we erkennen dat het here to stay is.

Terwijl de linkse intellectuelen hun leegte peilden, hun wonden likten en vervielen in postmoderne bescheidenheid (door sommigen aangeduid als 'zelfhaat'), hebben rechtse intellectuelen de profetenmantel opnieuw omgeslagen, zich hullend in de waarheid en de rechtvaardigheid van de westerse cultuur met haar 'ononderhandelbare' kernwaarden. Zij zien het niet als beneden hun stand om zich te beroepen op de 'ervaringswijsheid van de gemiddelde burger' (tegenwoordig beter bekend als 'onderbuikgevoel'). Het conservatisme (althans in de opvatting van Van Doorn) predikt juist zelfrelativering, maar hier ontmoeten we eerder een quasirevolutionair conservatisme dat zich fundeert op keiharde antropologische en politieke waarheden en juist te hoop loopt tegen het cultuurrelativisme van de linkse elite, dat alleen maar zou leiden tot zelfhaat, morele uitverkoop, vermijding en culturele onverschilligheid. Tegenover de dreigende 'islamisering' en 'zelfopheffing' van Nederland stellen zij de dure plicht om de kernwaarden van onze cultuur agressief uit te dragen, teneinde de apocalyptische beschavingsoorlog met de islam te kunnen winnen.

Van Doorn heeft deze historische uitdaging robuust en heldhaftig (want vrijwel in zijn eentje) opgepakt. Zijn verzamelde columns vormen tezamen een soort update van zijn rede over 'de intellectueel als ideoloog' en een tweede kritiek op de politieke intelligentsia (hoewel hij moeite bleef houden om deze rechtse intellectuelen als intellectuelen te zien). Niet voor niets noemden de 'vrienden van Ayaan' zich niet zo, maar ironisch 'de vrienden van Van Doorn', zoals Spruyt onlangs onthulde. Hij gold als hun meest formidabele tegenstander: terwijl de kritiek van anderen 
langs hen afgleed, kwam de zijne hard aan. Maar mijn stelling is ook dat Van Doorn de betekenis en draagwijdte van de populistische revolte heeft onderschat, en een zekere blindheid behield voor Fortuyn als politieke intellectueel. Net als Bart Tromp beschouwde hij het populisme vooral als een bedreigend politiek virus en een totalitaire verleiding in plaats van als een democratische uitdaging. Daarom is zijn laatste stuk 'Herfsttij der democratie' (in Nederlandse democratie), waarin de individualisering wordt aangewezen als de bron van alle maatschappelijke en politieke malaise, zo'n teleurstellend slotakkoord geworden. Dat het vooral de verbrokkeling van traditionele instituties en de vervlakking van traditionele ideologieën is die zou hebben geleid tot de ontaarding van de huidige democratie, is mijns inziens een zwaktebod dat onvoldoende gebruikmaakt van de sociologische verbeeldingskracht waarin Van Doorn zich elders zo'n meester betoonde.

Fortuyn deed hij af als een warhoofd, een charlatan zonder samenhangende ideeën, die hooguit als opschudder werkte en vooral opwinding en amusement bracht. Een citaat uit een column enkele weken na de moord, dat moeiteloos met andere kan worden aangevuld: 'Fortuyn was geen denker maar een popularisator, geen systeembouwer maar een verzamelaar van borreltafelwijsheden. Ga je daar een programma uit kneden, dan krijg je een reusachtig borreltafelverhaal maar geen politieke doctrine' (Trouw, 31 mei 2002). Vanaf het begin was hij neerbuigend over Fortuyn als voornaamste exponent van de personalisering en mediatisering van de politiek, als een 'politicus zonder partij' in het spoor van Van Mierlo en D66, die niet voortkwam uit een van de drie gevestigde ideologische stromingen van liberalisme, confessionalisme of socialisme. De LPF was in zijn ogen niet meer dan een 'persoonsgebonden protestmanifestatie' in de traditie van protestpartijen en -partijtjes die het nooit lang volhouden. Wel 'griezelig' vond hij het dat een man van buiten de politiek in zo korte tijd een zo omvangrijk deel van het electoraat achter zich wist te verenigen. Pims populariteit legde volgens Van Doorn een gevaarlijke zwakte in onze democratie bloot. Maar het streven naar meer volksinvloed in de vorm van rechtstreekse verkiezingen van ambtsdragers, referenda, et cetera, was een averechtse reactie: met het uitdelen van dergelijke 'massaspeeltjes' zouden we alleen maar van de regen in de drup komen (Trouw, 5 april 2002).

Geleidelijk beginnen we te beseffen dat het moderne populisme geen incident, tijdelijke afwijking of noodzakelijk reinigingsritueel is, maar een blijvend onderdeel van het politieke landschap (misschien was Van Doorn op het eind daarom zo pessimistisch gestemd). Daarvoor zijn verschillende redenen te noemen. Ten eerste dienen we ons rekenschap te geven van de positieve, mobiliserende kanten van de mediapolitiek en de personendemocratie. De populistische politieke stijl past beter bij de 
'nieuwe directheid' van de mediacommunicatie en bij de cultuur van een geïndividualiseerde en gemediatiseerde samenleving dan die van de traditionele politieke partijen. Ten tweede is er het brandende integratievraagstuk. Wat 'rechts integreren' inhoudt weten we inmiddels wel: assimilatie, aanpassing aan de 'leidende' cultuur, onvoorwaardelijk kiezen voor Nederland, verdediging van onze kernnormen en -waarden, van je geloof afvallen. Maar wat is 'links integreren' eigenlijk? Van Doorns multiculturalisme by default geeft hier per saldo onvoldoende antwoord op.

Ten derde hield Van Doorn vast aan zijn bekende these van de ideologische driedeling van liberalisme, christen-democratie en sociaal-democratie, zoals die was vormgegeven door klassieke volkspartijen zoals de VVD, het CDA en de PvdA. Maar die 'ideologische driehoek' (zoals de titel luidt van zijn bekende, samen met Piet de Rooy en Jos de Beus geschreven boek) is definitief gaan schuiven en dreigt zelfs in elkaar te klappen. Aan de rechterkant van het politieke spectrum kan men de eerder aangeduide convergentie waarnemen tussen liberalisme en nieuwe vormen van cultureel conservatisme, die al heeft geresulteerd in enkele afsplitsingen van de VVD en de vorming van de nationaal-populistische partijen van Wilders en Verdonk. Ook als speerpunt van dit nieuwe liberale conservatisme en nationalisme werpt het fortuynisme zijn schaduwen vooruit. Ter linkerzijde is het nog steeds wachten op eenzelfde soort ideologische vernieuwing en hergroepering.

'Men doet zijn vrienden tekort als men hen de volle scherpte der woorden onthoudt', zoals Menno ter Braak zei. Van Doorn zag in alle helderheid dat het populisme het politieke voertuig was geworden van het doorgeschoten individualisme en consumentisme in maatschappij en politiek. Maar de positieve kanten van deze individualisering zag hij niet. Hij was niet in staat om door de eigenaardige paradox van het moderne 'geïnstitutionaliseerde' individualisme heen te denken, dat een ideologisch voertuig is geworden van zijn eigen tegendeel: de nieuwe kuddementaliteit van consumenten die allemaal denken dat ze uniek, authentiek, eigen en apart (moeten) zijn. Er schuilt tragiek in het feit dat een van de grootste Nederlandse sociologen van de voorbije eeuw meende dat de individualisering het einde inluidde van de sociologie als vak, en niet bij machte was om de sociologische uitdaging ervan aan te gaan, anders dan via een lucide maar pessimistische cultuurkritiek. 


\section{Geraadpleegde literatuur}

Burawoy, M. (2005), 'For Public Sociology', American Sociological Review 70: 4-29.

Doorn, J.A.A. van (2009), Nederlandse democratie. Historische en sociologische waarnemingen, Amsterdam: Mets \& Schilt.

Pels, D. (200o), The Intellectual as Stranger. Studies in Spokespersonship, Londen/New York: Routledge. 



\section{Deel IV}

Van Doorn en de militaire sociologie 



\title{
7 Van Doorn in crisis \\ Over militaire transformatieprocessen
}

\author{
René Moelker
}

\section{Inleiding}

Wie met behulp van Google zoekt naar de combinatie J.A.A. van Doorn en het woord crisis, vindt vele treffers. Van Doorn schreef regelmatig over verschillende soorten crises, bijvoorbeeld met Kees Schuyt over die van De stagnerende verzorgingsstaat (1978), maar ook in zijn werk over het Duits socialisme (2007a) en in de laatste postuum verschenen bundel over democratie (Van Doorn 2009) speelt het crisisbegrip een rol. Het kan ook nauwelijks ergens anders over gaan bij een tegendraadse waarnemer die over sociale verandering schrijft. Het crisisbegrip staat ook centraal in Van Doorns benadering van de militaire sociologie en is daarmee ook een goede leidraad om uiteen te zetten welke oorspronkelijk door Van Doorn opgeworpen hypothesen tegenwoordig nog steeds een rol spelen in onderzoek en wetenschappelijke discussie.

Wat betreft de krijgsmacht was Van Doorn glashelder: het militarisme verkeerde in 1948 al in een crisis. Van Doorns eerste publicatie in Mens en maatschappij behandelde 'De crisis van het militarisme' (1948) en kennelijk is de krijgsmacht daar nooit uitgekomen, want getuige de hedendaagse missies in Uruzgan bevindt de militaire organisatie zich nog steeds in een crisis. Als wij Van Doorns redenering, zoals gepubliceerd in Trouw (2007b) volgen, lijkt het erop dat Nederland zich heeft laten foppen. In Afghanistan blijkt de strijd te gaan om een al eeuwenlang durende stammenstrijd en niet om een oorlog tegen het terrorisme. In Uruzgan lijken wij de Indische lessen niet ter harte te nemen. Net zoals indertijd bij de politionele acties zal het Nederland in Uruzgan niet lukken om de harten en geesten van de lokale bevolking te winnen. Daarom zou het zich niet moeten inlaten met dit militaire avonturisme.

In zijn militaire sociologie debiteerde Van Doorn vele hypothesen die altijd betrekking hadden op veranderingen in de krijgsmacht en die 
veranderingen werden met groot gevoel voor drama aangekondigd als 'crisis van ...' of 'het einde van ...' De meeste van die hypothesen, bijvoorbeeld de hypothese die het einde van de dienstplicht aankondigde of de hypothese die wees op de problemen rondom persoonsvorming welke hieronder besproken zullen worden, hadden grote voorspellende waarde. Een enkele keer verraadt een hypothese een achterliggend conservatief trekje in de auteur zelf. Zo was Van Doorn tegen participatie van vrouwen in de krijgsmacht. Meestal echter getuigt het werk van een visionaire geest waaruit analyses ontsproten die tot op de dag van vandaag hun actualiteitswaarde behouden hebben. In dit hoofdstuk zal verdedigd worden dat Van Doorn, met uitzondering van het onderwerp vrouwen in de krijgsmacht, niet zozeer een conservatief, maar een traditionalist was. Van Doorn vertrok van de klassieke taken waarvoor de krijgsmacht ontworpen was, en stond kritisch tegenover alles wat tegenwoordig Operations Other Than War genoemd wordt. Niet vanuit conservatisme, maar omdat volgens Van Doorn de krijgsmacht niet het juiste instrument is om daarbij ingezet te worden. De krijgsmacht is er immers om oorlogen uit te vechten en niet voor zaken die bijvoorbeeld politioneel of wederopbouwend van karakter zijn. Dat is een traditionele opvatting aangaande taak en functie van de krijgsmacht en alles wat deze traditionele taak aantast brengt de militaire organisatie in een crisis.

In dit hoofdstuk gaat het niet zozeer om de vraag wat Van Doorn met de gedachtewereld om zich heen heeft gedaan, welke briljante analyses hij wel of niet ontwikkeld heeft, maar om de vraag wat wij met het werk van Van Doorn hebben gedaan, welke hypotheses de tand des tijds hebben doorstaan en welke niet. In de volgende paragraaf wordt de rol van Van Doorn bij de ontwikkeling van de militaire sociologie beschreven. Het baanbrekende werk ten aanzien van militaire organisatie en militaire professie, dat in Van Doorns proefschrift centraal stond, blijkt nog altijd een vertrekpunt te zijn voor militair sociologen geïnteresseerd in theorievorming. Vervolgens komen vermaatschappelijking en legitimiteit aan de orde, gevolgd door de befaamde hypothese die het einde van de massalegers aankondigde. Afgesloten wordt met een paragraaf over socialisatie in internaatsverband en de conclusie. Op het hoofdwerk Ontsporing van geweld (Van Doorn en Hendrix 1970) wordt ingegaan in het hoofdstuk van Jan van der Meulen. Om die reden komt dit militairsociologische werk hier slechts bij referentie aan de orde. Het zal blijken dat Van Doorns studies naar de aard van de legitimiteitscrises met name waardevol zijn, omdat zij de lezer attenderen op belangwekkende transformatieprocessen. 


\section{De 'grote drie' ('big three')}

Als de invloed van Van Doorn uitgedrukt zou moeten worden in zogenaamde impact scores, dan zou zijn militair-sociologisch werk binnen het volumineuze oeuvre eruit springen, omdat juist dit werk relatief sterk internationaal georiënteerd is en ook in journals gepubliceerd werd. Gelukkig bestaat er voor het militair-sociologische werk dan ook een Engelstalige 'draagbare' Van Doorn (1975a), getiteld The Soldier and Social Change, die onder andere samenvattingen biedt van eerder gepubliceerde Nederlandstalige klassiekers. Omdat de belangrijkste hypothesen met betrekking tot de ontwikkelingen op het gebied van krijgsmacht en samenleving hierin besproken worden, vormt dit werk het belangrijkste referentiepunt voor Van Doorns militaire sociologie. Maar behalve het inhoudelijke werk, waarover later meer, is Van Doorn ook een belangrijke initiator en inspirator geweest voor de militaire sociologie. Op zijn beurt ontleende Van Doorn, net zoals vele andere klinkende namen in de sociologie, zijn interesse voor 'oorlog' en 'geweld' aan zijn persoonlijke ervaringen met deze fenomenen.

Na de Tweede Wereldoorlog krijgt de sociologie een belangrijke impuls doordat sociologen hun militaire ervaringen vertalen naar sociologische inzichten en empirische studies. Zo heeft Stouffers (1950) naoorlogse studie naar The American Soldier een belangrijke spin-off gehad naar de referentiegroepentheorie zoals deze door Robert Merton (1967) te boek werd gesteld. George Homans (1946) heeft na de Tweede Wereldoorlog zijn ervaringen als commandant van 'The Small Warship' beschreven in een zeer leesbare en interessante bijdrage aan het tijdschrift American Sociological Review. Edward Shils en Morris Janowitz publiceerden in 1948 een baanbrekend artikel waarin door middel van interviews met Duitse krijgsgevangenen het belang van groepscohesie boven politieke ideologie aangetoond werd. Net zoals deze sociologen zich lieten inspireren door hun persoonlijke oorlogservaringen, sublimeerden ook de persoonlijke ervaringen van Jacques van Doorn in wetenschappelijk werk. Zo schrijft hij in een column (Van Doorn 2007c):

Indien je, zoals in mijn geval, als adolescent de Duitse bezetting meemaakt om een half jaar na de bevrijding in mei 1945 , te worden opgeroepen voor militaire dienst, die drieënhalf jaar duurt, de langste tijd in Nederlands-Indië doorgebracht - als je dit alles zonder kleerscheuren doorstaat en enigszins geïntrigeerd meemaakt, ligt de keuze van een sociologisch proefschriftonderwerp nogal voor de hand: de krijgsmacht als organisatie en als geweldsapparaat. Als would-be historicus volgde ik ook het spoor terug naar de tijd van Prins Maurits, toen het huidige militaire instituut voor het eerst vorm begon te krijgen. 
Van Doorn wist zijn eigen fascinatie met oorlog en geweld ook op anderen over te brengen, op zijn studenten, maar ook binnen sociologische organisaties. In 1970 werd de Research Committee 01 Armed Forces and Conflict Resolution van de International Sociological Association opgericht waarbij Van Doorn de rol van vice-president onder Morris Janowitz op zich nam om vervolgens in de periode van 1974 tot 1977 het presidentschap waar te nemen. Gezamenlijk met Janowitz en Raymond Aron richtte Van Doorn in 1974 het nu gerenommeerde tijdschrift Armed Forces and Society op en maakte jarenlang deel uit van de kernredactie. Van Doorn had groot respect voor Janowitz en niet alleen als wetenschapper, maar ook als vriend. Desondanks schreef hij in 1966 aan Janowitz dat hij betwijfelde ooit nog een nieuw paper in de militaire sociologie te schrijven, omdat het onderwerp nog maar marginaal interessant was, in zijn eigen woorden 'a side-line interest' (Burk 1993: 177). Deze brief dateert van vier jaar voor de publicatie van Ontsporing van geweld (Van Doorn en Hendrix 1970), een publicatie die men geenszins een 'side-line' kan noemen. Integendeel, Ontsporing van geweld moet gezien worden als een mijlpaal van de militaire sociologie en daarom is ook een verkorte versie opgenomen als (laatste) hoofdstuk van The Soldier and Social Change (1975a). Met de titel van dat hoofdstuk, 'Use of Violence in Counter Insurgency', is ook gelijk de actualiteit van dit werk gegeven. Alle principes en mechanismen aangaande ontsporing welke in dit boek beschreven zijn, zijn ook geldig in hedendaagse Counter Insurgency operaties in Irak en Afghanistan. Met het conceptueel kader kan men de ontsporingen in bijvoorbeeld de Abu Ghraib gevangenis uitstekend begrijpen en verklaren.

Niet alleen vormt de militaire sociologie - ondanks de desavouerende brief aan Janowitz - een permanente rode draad in het werk van Van Doorn, zij is ook een liefde waarnaar hij iedere keer terugkeert. Achteraf mogen wij hem zeker tot de 'grote drie' (Aron, Janowitz en Van Doorn) van deze subdiscipline rekenen.

Na dit kort exposé over de internationale invloed van het werk van Van Doorn binnen de militaire sociologie wordt in het vervolg van dit hoofdstuk op de meest saillante hypothesen ingegaan. De insteek daarbij, zoals al eerder gezegd, is de vraag hoe andere wetenschappers de thema's verder hebben uitgewerkt in vervolgonderzoek.

\section{Militaire organisatie en het militaire beroep}

Van Doorns industriële en organisatiesociologie is geworteld in zijn militaire sociologie en dit wordt het duidelijkst in zijn proefschrift Sociologie van de organisatie uit 1956 en het boek Organisatie en maatschappij uit 1966. Het centrale argument start met een technologisch oorzakelijke factor.

De technologie van het lontslot was belangrijk voor de ontwikkelin- 
gen in de militaire professie in de late zestiende en vroege zeventiende eeuw, omdat zij het mogelijk maakte om de zware cavalerie - tot dan toe het gevaarlijkste wapen - op een afstand te houden door vuurkracht. Wanneer de aanstormende ruiters het musketvuur passeerden, liepen zij vast op lansen welke door de piekeniers (de huidige infanterie) gehanteerd werden. Behalve de technologische innovaties vereiste het verlangen om de Spanjaard militair te verslaan ook een nieuwe wijze van organiseren en dat veronderstelde op zijn beurt weer een wetenschappelijke analyse die zelfs teruggreep op strategie en tactiek van de oude Romeinen. Het maken van de wetenschappelijke analyse was de taak die Maurits en zijn neef Willem Lodewijk zich stelden en zij bootsten daarom allerlei formaties na in het klein. Met tinnen soldaatjes werden alle organisationele mogelijkheden uitgetest.

Het afschieten van musketten was gevaarlijk, omdat het kruit zowel in de loop als op de pan aan de zijkant van het musket moest worden aangebracht, waarna het kruit tot ontsteking werd gebracht door een lont die de musketier gedurende de hele procedure in de hand hield. De musketier, voorzien van kruithoorn en omhangen met diverse kruitladingen, 'speelde' met open vuur; de lont die de ontsteking van het kruit op de pan mogelijk maakte. Vanwege deze werkwijze was een goede training extreem belangrijk. Nieuw was dat er gewerkt moest worden met wapens die gestandaardiseerd waren en door de staat verstrekt. Voor de tijd van Maurits bracht iedere soldaat meestal zijn eigen persoonlijke wapen mee. Deze standaardisering was van militair belang, omdat zij de totale vuurkracht verbeterde, maar bovendien symboliseerde zij een verdere stap in de ontwikkeling van het geweldsmonopolie in handen van de staat.

De technologie van het musket verhoogde niet vanzelfsprekend de vuurkracht van het leger van de prins. Om de techniek te laten renderen moesten Maurits en Willem Lodewijk hun organisatie en training aanpassen. De zwakte van de Spanjaarden was namelijk hun gebrek aan mobiliteit. Zij manoeuvreerden normalerwijze met carrés van 300 soldaten (musketiers en lansiers) en een dergelijke formatie beweegt nu eenmaal traag. Door met kleinere eenheden te werken kon de Spanjaard uitgemanoeuvreerd worden. Maurits en Willem Lodewijk brachten daarom de compagnieën van 300 man terug naar 100, maar handhaafden het aantal officieren per compagnie. Daarmee werd leiderschap en instructie (in de drill / exercitie) veel belangrijker. Discipline en exercitie stonden voorop. Om continu vuur uit te kunnen brengen moesten de musketiers terugmarcheren tot de achterste gelederen van het carré. Daar kon het musket vervolgens, volgens een procedure die anderhalf tot drie minuten in beslag nam, herladen worden. Om de laadtijd terug te dringen werd een wetenschappelijke arbeidsanalyse (time-motion study) 
gemaakt van de handelingen die nodig waren ten behoeve van het hanteren van de piek en de musket. Afbeeldingen als die in figuur 4 werden met het oog op instructie in 'onderwijsboeken' uitgegeven, zodat buitenlandse huurlingen aanschouwelijk onderwijs konden krijgen. Bovendien werd het beloningssysteem verbeterd (in het oude systeem stak de kapitein-wervingsofficier regelmatig geld in zijn eigen portemonnee terwijl hij de vacatures onvervuld liet).

Figuur 4 Illustraties van Jacob de Gheyn ${ }^{1}$

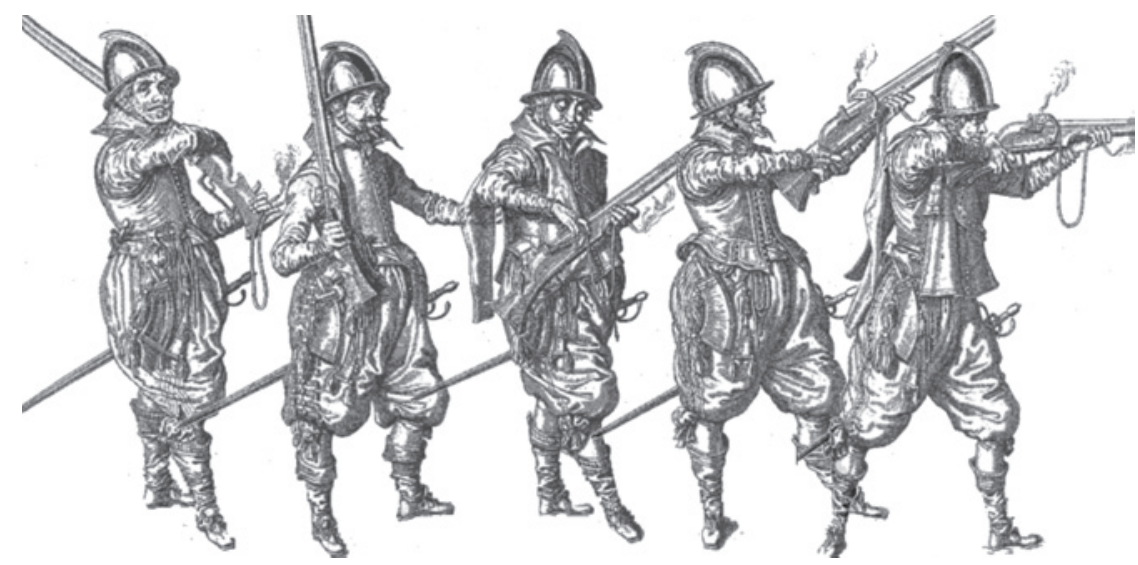

Het is opvallend hoe modern Maurits in zijn benadering van het organiseren was. Hij was Ford en Taylor driehonderd jaar voor bij de ontwikkeling van een systeem dat de principes van scientific management omvatte en dat tegelijkertijd de kwaliteit van de arbeid verhoogde door meer nadruk op veiligheid (omgaan met kruit en open vuurlonten), instructie (onderwijsmethoden), exercitie (routine door herhaling), discipline, betere door de staat verstrekte wapenen en een betere beloning. Maurits had ook hart voor zijn mensen (wat tegenwoordig soft-HRM genoemd zou worden). Zo had raadspensionaris Oldenbarnevelt liever snelle resultaten ten koste van de manschappen, terwijl Maurits zijn soldaten niet wilde opofferen voor een snel succesje. De soldaten waren zoveel beter af met het systeem van Maurits dat hij van het volk en zijn soldaten de eretitel 'soldatenkoning' kreeg.

De dynamiek in het model, dat Van Doorn illustreerde aan de hand van de legerhervormingen van Maurits, is gebaseerd op fusieprocessen en wel de fusie van professie en organisatie. Het belang van fusieprocessen, weliswaar op andere wijze uitgewerkt maar met eenzelfde basismechaniek, wordt onderstreept door recentelijk herontdekte studies van Norbert Elias (2007) naar de herkomst van het beroep van marineofficier. Ook Janowitz (1960) wijst in zijn hoofdwerk The Professional Sol- 
dier enkele malen op fusieprocessen. Elias en Van Doorn waren op het moment dat zij de hierboven genoemde boeken schreven niet bekend met elkaars werk en ook Janowitz ontwikkelde zijn werk onafhankelijk van Van Doorn (Van Doorn schreef deze werken immers in het Nederlands). Zoals vaak bij het verschijnsel 'serendipiteit' hing het 'idee' in de lucht en werd het door diverse auteurs min of meer gelijktijdig opgepikt. Nadat het werk van Van Doorn internationaal bekend werd, hebben echter alle militair sociologen die zich richten op professionalisering voortgebouwd op de basis die door de 'klassieken' Van Doorn en Janowitz gelegd is (terwijl de militair-sociologische studie van Elias slechts door enkelen opgemerkt werd omdat deze studie in de jaren vijftig nooit als geheel gepubliceerd werd in British Journal of Sociology.

De invloed van Van Doorn kan men, om slechts een tweetal belangrijke auteurs te noemen, terugzien in het werk van Bengt Abrahamsson (1972), die wijst op de correlatie tussen de sociale herkomst van officieren en de politieke oriëntatie, en in het Instituut-Beroep model van Charles Moskos (1970). In Nederland is eveneens aangesloten bij deze traditie van onderzoek die zich vooral richt op de analyse van carrièrepatronen en sociale herkomst (Oosterhuis 1993; Klinkert 2003). Nog steeds wordt op de Nederlandse Defensie Academie naar het vroege werk van Van Doorn verwezen om arbeidssociologische begrippen als 'taaksplitsing' en 'fordisme' te illustreren aan de hand van militaire voorbeelden.

\section{Vermaatschappelijking en legitimiteitscrisis}

Van Doorn (1975b: 90) definieerde legitimiteit als 'the capacity of a social or political system to develop and maintain a general belief that the existing social order and its main institutions are generally appropriate'. Gebaseerd op deze definitie, wijzende op de teloorgang van massa(dienstplicht)legers, het disproportionele en onrechtmatige gebruik van geweld in voormalige koloniën en de toenemende vervreemding van de samenleving concludeerde Van Doorn dat er sprake was van een legitimiteitscrisis. Die crisis is zeer zeker gerelateerd aan democratisering en vermaatschappelijking, en de toegang van vrouwen tot de krijgsmacht is van deze ontwikkelingen een markante exponent.

Zestig jaar geleden lagen de oorzaken van de crisis van de militaire organisatie volgens Van Doorn bij de toenemende democratiseringsbehoefte en de individualisering, oorzaken die in zijn hele oeuvre een grote rol spelen. De ontwikkeling in het werk is overigens markant, omdat deze gerelateerd is aan de vraag die in de militaire sociologie steeds - zij het in verschillende bewoordingen en betrekking hebbende op verschillende dimensies - terugkomt, namelijk: moet de krijgsmacht apart staan ten opzichte van de wijdere samenleving of moet zij daarin 
juist geïntegreerd zijn? Deze vraag komt terug in de discussie over mogelijke afwijkende waarden en normen binnen de krijgsmacht (Bestaat er een zogenaamde 'militaire geest'? Zijn gezagsverhoudingen in de krijgsmacht archaïsch en disfunctioneel?), in de vraag of de traditionele militaire institutie met haar nadruk op motivatie door waarden als 'God en vaderland' nog wel een adequate organisatievorm is, maar ook in de afspiegelingsvraag (demografische vragen naar diversiteit, etniciteit en/ of gender). Het gehele terrein wordt vaak aangeduid met de brede term 'civiel-militaire verhoudingen'. Van Doorns positie hangt sterk af van de specifieke dimensie binnen deze verhoudingen.

In de eerste publicatie in Mens en maatschappij stelt Van Doorn (1948) dat de krijgsmacht vervreemd is van haar moedersamenleving. Het militarisme verkeert daarom in een crisis. Er zijn volgens hem twee wegen om de geïsoleerde positie van de krijgsmacht op te heffen, namelijk het fascisme of democratisering. Bij de eerste weg zou men de samenleving militariseren, bij de tweede wordt het leger vermaatschappelijkt. Die eerste weg is niet verkieselijk. Van Doorn bekritiseert de autoritaire gezagsverhoudingen in scherpe bewoordingen: 'We weten het: familiariteit in het leger is uit den boze, de officier moet meerdere blijven - hetgeen hem met wat tact, dankzij zijn hogere ontwikkeling altijd zal gelukken. Maar hij behoeft geen halfgod te zijn!' (1948: 303).

De autoritaire gezagsverhoudingen van weleer zijn na de Tweede Wereldoorlog niet meer van de tijd. Blijft dus over de weg van de vermaatschappelijking en daarin onderscheidt Van Doorn verschillende mogelijkheden, onder andere de ontwikkeling naar een internationaal politieleger (een ontwikkeling die de moderne vredes- en wederopbouwmissies voorafschaduwt) of de ontwikkeling in de richting van een 'sociaal-ingestelde gemeenschapsdienst' (vergelijk de immer wederkerende discussie over een maatschappelijke dienstplicht). Burgerschapsvorming, democratische persoonlijkheidsvorming, nationale weerbaarheid en gemeenschapsbesef staan daarbij centraal (1948: 307-310). Het is geen versleten discussie die hier aangesneden wordt, maar een debat dat ook vandaag de dag wordt gevoerd en dat recentelijk nog aanleiding heeft gegeven tot verandering in gedragscodes en het aanscherpen van 'sociaal leiderschap' als centraal concept voor het voorkomen van onoorbaar gedrag.

Maar vermaatschappelijking en democratisering hebben ook hun prijs en Van Doorn wijst er in de jaren zeventig op dat de vermaatschappelijking zo ver kan doorschieten dat deze het functioneren van de krijgsmacht als geweldsinstrument kan hinderen. Dat wil niet zeggen dat hij terug wil naar het verleden, maar wel dat de balans kwijt is. Oppervlakkige lezing van Van Doorn zou tot de conclusie kunnen leiden dat hij uiteindelijk toch een conservatief is (geworden). In het standaardboek ten behoeve van de officiersopleidingen van de late jaren zeventig, 
het door Brentjens en Turpijn (1977) geredigeerde Welzijn en krijgsmacht heeft Van Doorn twee hoofdstukken aangeleverd: 'De krijgsmacht in de verzorgingsstaat' (Van Doorn 1977: 33-43) en 'Voortgaande vermaatschappelijking of hernieuwde militarisatie?' (Van Doorn 1977: 84-91). In deze hoofdstukken is de krijgsmacht wederom in een crisis geraakt en 'in het defensief: de militaire organisatie is niet meer een toonaangevend instituut, maar meer een verwerpelijk model' (1977: 85). De bodem van de legitimiteit is de krijgsmacht ontvallen. Bij wijze van oplossing voor dit probleem zou men, volgens Van Doorn, het model van de vermaatschappelijking nog verder kunnen doorvoeren, maar men zou ook kunnen kiezen voor het alternatieve model van de hermilitarisatie. In de jaren zeventig zou alleen al de pure term 'hermilitarisatie' kippenvel veroorzaakt hebben bij de gemiddelde linkse activist die de norm was geworden voor de Nederlandse sociologie.

Van Doorn doelde echter op een vrijwilligersleger, wat wij tegenwoordig een beroepsleger zouden noemen, en hij sloot daarbij nauw aan bij de gedachtewereld van Charles Moskos ${ }^{2}$ die een ontwikkeling schetst van de oude krijgsmacht als 'totale institutie' naar een moderne beroepsorganisatie. Het vermaatschappelijkte leger had zijn gevechtscapaciteit verloren en dat leidde ertoe dat het gebruik van geweld als kernfunctie van de krijgsmacht diende te worden gecamoufleerd (Van Doorn 1977: 87). ${ }^{3}$ Voortgaande vermaatschappelijking zou alleen maar verdere afbreuk aan de gevechtskracht doen. Daarom zijn 'sommige deskundigen (...) van mening dat de beweging tot voortgaande vermaatschappelijking thans over haar hoogtepunt heen is' (idem: 88).

De term 'hermilitarisatie' doet juist heel sterk denken aan een leger dat weer kan vechten, en zie daar...: anno 2009 is het noodzaak voor de krijgsmacht om gevechtshandelingen te paren aan wederopbouw en politionele taken (ordehandhaving). Het is echter wel een modern leger, met moderne - relatief egalitaire - gezagsverhoudingen en wederzijds respect, dat zich conformeert aan de arbeidsmarkt en dat volledig geïntegreerd is waar het democratische waarden en normen betreft. Van Doorn gaf blijk van een vooruitziende geest die in de jaren zeventig waarschijnlijk vaak abusievelijk voor conservatisme aangezien werd. Een interpretatie die waarschijnlijk dichter bij de belevingswereld van Van Doorn staat, is dat de krijgsmacht eenvoudigweg gevechtskracht dient te leveren en voor andere taken veel minder geschikt is. Tegen een beroepsleger had hij geen principiële bezwaren, maar zo'n leger impliceert ook andere facetten van vermaatschappelijking en legitimiteit die de toegang van vrouwen tot de militaire organisatie betreffen en hiertegen had Van Doorn wel bezwaren.

Daar waar hij de gelijke toegang van vrouwen tot academische studies en wetenschappelijke functies als natuurlijk beschouwde, stelde 
hij zich tegendraads op ten aanzien van het onderwerp vrouwen in het leger: 'Gelijke rechten in de krijgsmacht: waanzin' (Van Doorn 2006a). Hij stelde dat 'De eis aan jongemannen die soms maanden op zee zijn, zich in het gezelschap van jonge vrouwelijke collega's ontspannen en onbevangen te gedragen, grenst aan het onmogelijke. De militaire bureaucraten die dit hebben bedacht, hebben de kat op het spek gebonden en vervolgens hun kop in het zand gestoken.' Hij vond dat zijn stelling in 2006 bewezen werd door de incidenten die op de Tjerk Hiddes hadden plaatsgevonden. Oppervlakkig lijkt het standpunt van Van Doorn op dat van de Israëlische historicus Van Creveld (2001) en we zouden wederom kunnen denken dat Van Doorn een rabiate conservatief is. Maar Van Crevelds redenering is echt anders. In zijn boek Men, Women and War wijst hij op genderverschillen die biologisch ingebakken zijn. Vrouwen zijn eigenlijk superieur aan mannen, omdat zij de spil zijn in de menselijke voortplanting. Mannen compenseren hun gebrek aan creatieve kracht door machogedrag en dat uit zich vooral in fysiek geweld, machtswellust en subordinatie van zwakkeren. De alfa-hond heeft immers meer kans om zijn genen aan de volgende generatie door te geven en dat is volgens Van Creveld ook de reden waarom mannen oorlogvoeren. In zijn laatste publicatie over The Culture of War (2008) stelt deze auteur daar bovenop onomwonden dat mannen geweld simpelweg leuk vinden. Van Doorn zou het niet met de causale sociobiologische redenering eens zijn. Hij wijst veel meer op verminderde gevechtskracht vanwege het verschil in fysieke kracht, op demoralisatie van de troepen als zij een vrouwelijke buddy verliezen of gegijzeld of onteerd zien worden, en op problemen met seksuele deprivatie en daaruit voortvloeiende spanningen, maar hij is het wel eens met Van Crevelds conclusie: vrouwen horen niet in de krijgsmacht!

$\mathrm{Er}$ is veel tegen bovenstaande stellingname in te brengen. Krijgsmachten hebben personeel nodig en bovenal hebben zij diversiteit in dit personeel nodig, omdat zij dankzij deze diversiteit de toegenomen taakcomplexiteit beter kunnen hanteren (Richardson et al. 2007; Moelker en Bosch 2008). Naast vechtmissies worden vredesmissies uitgevoerd en al deze missies vereisen een pluriformiteit aan kwaliteiten. De behoefte aan vrouwelijk personeel is met name groot in vrijwilligerskrijgsmachten, hetgeen ook blijkt uit een sterke correlatie tussen het opschorten van de dienstplicht en de toename van de participatie van vrouwen in de krijgsmacht (Carreiras 2006). Daarnaast vertrekt de juridische regelgeving vanuit het gelijkheidsbeginsel en vanzelfsprekend kunnen vrouwen in een door technologie gedomineerde krijgsmacht even goed vechten als mannen. Spierkracht is voor de meeste eenheden niet meer doorslaggevend (al moet wel op infanteriewerk als uitzondering gewezen worden). 
Langzaam maar gestaag nemen de aantallen vrouwen toe, niet alleen bij kleine of middelgrote militaire mogendheden, maar vooral ook bij grootmachten (vermits zij de dienstplicht hebben opgeschort). Fluctuaties in de percentages zijn er evenwel, en vaak is daar ook een verklaring voor. Zo bestaat de interventiemacht van de USA in Irak en Afghanistan vooral uit reservisten, wat het algemene participatiecijfer voor vrouwen in de krijgsmacht doet afnemen voor het jaar 2006. Het participatiecijfer voor Nederland stagneert ondanks een voorbeeldig emancipatiebeleid. De oorzaken daarvan zijn niet geheel duidelijk. Mannelijkheidscultuur, de verhouding werk en privé, de belasting van uitzendingen, et cetera, spelen mogelijkerwijze een rol, maar ook het ontbreken van politieke directieven die de organisatie dwingen om het 'koperen' plafond te doorbreken. Sommige landen zijn niet met Nederland te vergelijken, omdat zij nog een dienstplichtsysteem hanteren. Als men de participatiegraad in andere landen, met name die in Frankrijk, de USA en Canada, met die in Nederland vergelijkt, mag men misschien wel suggereren dat het Nederlandse emancipatiebeleid gefrustreerd wordt door militaire onwil (vergelijkbaar met de stellingname van Van Doorn) en politieke onmacht.

Resumerend en concluderend: Van Doorn begon zijn carrière met de stelling dat de krijgsmacht maatschappelijk beter geïntegreerd moest zijn. Deze stelling had vooral betrekking op archaïsche gezagsverhoudingen. Gaandeweg verschuift de positie van de militair socioloog, omdat de balans tussen de vermaatschappelijking en de effectiviteit van de militaire organisatie in zijn ogen een scheefgroei vertoonde. Hij introduceert als alternatief voor de vermaatschappelijking het model van de 'hermilitarisatie' en zegt daarmee in feite dat de krijgsmacht toch net iets anders is dan de burgersamenleving. Hoe anders die krijgsmacht is blijkt uit de opinie dat vrouwen er niet thuis horen.

\section{Het einde van de massalegers}

Van Doorns meest profetische voorspelling op militair-sociologisch gebied betrof zijn hypothese met betrekking tot 'The Decline of the Mass Army' (1975c). Wederom wijst Van Doorn op een transformatieproces, maar deze keer ontbreekt het drama. Crisis in legitimiteit is wel een aanleiding en oorzaak voor verandering, maar het is deze keer geen uitkomst.

Midden in de Koude Oorlog waar de militaire kracht van landen afgemeten wordt aan zowel het wapenarsenaal als aan de omvang van de dienstplichtlegers, debiteert Van Doorn de stelling dat massalegers in de afzienbare toekomst obsoleet zullen worden. Van Doorn beseft zelf 
Tabel 3 Ontwikkeling van de militaire en civiele arbeidsdeelname van vrouwen in de NAVO-landen ${ }^{4}$

\begin{tabular}{|c|c|c|c|c|c|}
\hline & \multicolumn{3}{|c|}{$\begin{array}{l}\text { Militaire arbeids- } \\
\text { deelname vrouwen }\end{array}$} & \multicolumn{2}{|c|}{$\begin{array}{l}\text { Civiele arbeids- } \\
\text { deelname vrouwen }\end{array}$} \\
\hline & 2001 & 2006 & 2007 & 2000 & 2007 \\
\hline België & 7,6 & 8,3 & 8,25 & 52 & 60 \\
\hline Bulgarije & - & 6 & - & 46 & 55 \\
\hline Canada & $\mathrm{II}, 4$ & 12,8 & 17,3 & - & - \\
\hline Tsjechische Republiek & 3,7 & 12,2 & - & 57 & 57 \\
\hline Denemarken & 5,0 & 5,3 & 5,4 & 72 & 73 \\
\hline Frankrijk & 8,5 & 13,3 & 14 & 55 & 60 \\
\hline Duitsland & 2,8 & 6 & 7,5 & 58 & 64 \\
\hline Griekenland & 3,8 & 5,4 & 5,6 & 42 & 48 \\
\hline Hongarije & 9,6 & 17,6 & 17,3 & 50 & 51 \\
\hline Italië & 0,1 & 1,6 & 2,6 & 40 & 47 \\
\hline Letland & - & - & 23 & 54 & 64 \\
\hline Litouwen & - & 12,5 & 12 & - & - \\
\hline Luxemburg & - & 5,7 & - & 50 & 56 \\
\hline Nederland & 8,0 & 9 & 9 & 64 & 70 \\
\hline Noorwegen & 3,2 & 7 & 7,1 & - & - \\
\hline Polen & 0,1 & 0,5 & 1 & 49 & 51 \\
\hline Portugal & 6,6 & 12 & 13 & 61 & 62 \\
\hline Roemenië & - & 5 & 6,4 & 58 & 53 \\
\hline Slowakije & - & 7,7 & 8,7 & 52 & 53 \\
\hline Slovenië & - & & 15,3 & 58 & 63 \\
\hline Spanje & 5,8 & 13,5 & 12 & 41 & 55 \\
\hline Turkije & 0,1 & 3,1 & - & - & - \\
\hline Verenigd Koninkrijk & 8,1 & 9,1 & 9,3 & 65 & 66 \\
\hline Verenigde Staten & 14,0 & 10,5 & - & 68 & 66 \\
\hline
\end{tabular}

ook dat hij een controversiële stelling verdedigt en daarom opent hij zijn artikel dan ook met de woorden 'At first sight it might seem ironic to speak of the decline of the mass army in this day and age, when peace-time armed forces are greater and defence expenditure is higher than even before.' Maar Van Doorn wist op grond van eerste aanwijzingen een trend te ontwaren die hij kon extrapoleren naar de toekomst. Het einde van de dienstplichtsystemen zou nabij gebracht worden door een afname in de legitimiteit van de krijgsmacht en een 'crisis as a result of their (the armed forces, RM) increasing unpopularity with the public' (Van Doorn 1975a: 52). ${ }^{5}$ Grootschalige legers zijn niet meer nodig. Afschrikking wordt veel meer tot stand gebracht met behulp van technologische middelen (kernwapens). Het westerse streven naar politieke 
invloed neemt steeds vaker niet-militaire vormen aan. Waarom territoria veroveren als men de financiële markten kan beheersen door economische expansie? Vandaar een toenemende voorkeur voor vrijwilligerskrijgsmachten. Het Verenigd Koninkrijk en de Verenigde Staten waren voorlopers in deze ontwikkeling en het zou tot na de val van de Muur in 1989 duren voordat de andere westerse staten de trend volgden.

Van Doorn wijst op nog meer oorzaken die ten grondslag liggen aan de verandering. Zo betekent een kleiner dienstplichtleger dat de lasten van de dienstplicht ongelijker verdeeld worden over de bevolking. Deze onrechtvaardigheid zal volgens Van Doorn ongetwijfeld leiden tot het einde van de dienstplicht. Aan een omvangrijke krijgsmacht is in een hoogtechnologische omgeving nauwelijks behoefte. De krijgsmacht kent vele specialisten en naarmate de differentiatie in de militaire beroepenstructuur toeneemt, zullen ook steeds meer non-combattanten (denk aan logistieke en andere ondersteunende functies) werkzaam worden bij de krijgsmacht. De tooth-to-tail ratio verandert aldus, waardoor de typische 'zandhaas', de infanterist, al lang niet meer model staat voor de hedendaagse soldaat. Verder zal de toenemende democratisering het onmogelijk maken om nog langer onkritische massa's op de been te krijgen. Aan die ontwikkeling dragen ook toenemend individualisme, subjectivisme en hedonisme bij. Omdat de dienstplicht als een dwangsysteem ervaren wordt, doet hij zelfs afbreuk aan de legitimiteit van de staat. Op basis van deze analyse voorspelt Van Doorn niet alleen het einde van de dienstplicht maar ook het volgende.

1. Een toename van het belang dat aan arbeidsomstandigheden, loon, carrièremogelijkheden en pensioenen wordt gehecht, en daarmee samenhangend wervingstekorten in tijden van hoogconjunctuur.

2. Een toename van het gebruik van huurlingen.

3. Een afname van de representativiteit in de sociale samenstelling van het personeel waarbij Van Doorn vreesde voor een oververtegenwoordiging van etnische minderheden indien deze ook oververtegenwoordigd zouden zijn op de voor de krijgsmacht relevante delen van de arbeidsmarkt.

4. Een oververtegenwoordiging van personeel met een conservatief profiel.

5. Een verschuiving in de motivatie van 'roeping' naar 'beroep' in de waardeoriëntatie van toekomstig militair personeel.

Het is opmerkelijk hoeveel voorspellingen van Van Doorn uitgekomen zijn. Op alle vlakken zijn de hypothesen aanleiding geweest tot verder onderzoek waarbij soms ook zeer expliciet naar Van Doorn als bron van de hypothese wordt verwezen, bijvoorbeeld in het werk van Karl Haltiner (1998) of Van der Meulen en Manigart (1997). Met name het kwanti- 
tatief zeer degelijk onderbouwde werk van Haltiner en Szvircsev Tresch (2008) onderschrijft de relevantie van Van Doorns oorspronkelijke hypotheses. Deze laatste auteurs wijzen op enkele mechanismen die verbonden zijn met de overgang naar vrijwilligerskrijgsmachten (zie figuur 5). Op dit moment hebben België, Nederland, Spanje, Frankrijk, Portugal, Italië en Hongarije de dienstplicht opgeschort. In landen als Denemarken, Bulgarije, Griekenland en Polen wordt gediscussieerd over de mogelijkheid tot opschorten en deze discussie is in lijn met de voorspellingen van Van Doorn. Immers, de lasten van de dienstplicht worden in deze landen gedragen door slechts een kleine groep van jonge mannen die tussen 10 en 50 procent van de totale groep geschikte mannen groot is en daarmee staat de legitimiteit van de dienstplicht in deze landen ter discussie. Zweden heeft in het voorjaar van 2009 besloten om het dienstplichtsysteem ingrijpend te veranderen, en beraadt zich nu op de wijze waarop die veranderingen in 2010 geïmplementeerd moeten worden. Vaak ziet men dat dienstplichtsystemen ter discussie gesteld worden op het moment dat de nationale veiligheid afgewenteld kan worden op een systeem van collectieve verdediging zoals door de NAVO wordt geboden. Griekenland en Turkije zijn bijzondere gevallen waar geopolitieke redenen het onwaarschijnlijk maken dat de dienstplicht op korte termijn opgeschort zal worden. In Duitsland is wel regelmatig discussie over de dienstplicht, maar ook daar zijn politiek-maatschappelijke redenen (onder andere de Zivildienst waar de gezondheidszorg van afhankelijk is) een rem op mogelijke veranderingen. In Zwitserland is de dienstplicht het minst omstreden met een dienstplichtratio van 100 procent, hoewel de maatschappelijke discussie wel steeds vaker gevoerd wordt.

Met betrekking tot het merendeel van de subhypotheses heeft Van Doorn gelijk gekregen. Rekrutering, werving, behoud, maar ook doorstroom van personeel zijn cruciaal geworden voor het organisationeel overleven van de krijgsmacht, zodat beloning, arbeidsvoorwaarden, inspraak, medezeggenschap en vele andere personeelstechnische zaken tegenwoordig marktconform zijn. Sterker nog, in de concurrentie om personeel moet Defensie zich zelfs een betere werkgever betonen dan haar rivalen. Representativiteit blijkt inderdaad een probleem, maar niet op de wijze waarop Van Doorn verwachtte: het zijn juist niet de minderheidsgroeperingen die zich laten werven, maar vooral jonge blanke mannen (Richardson et al. 2007). Het conservatisme binnen de krijgsmacht blijkt eerder een uiting van pragmatisme, het zijn immers de partijen rechts in het politieke spectrum die een groot defensiebudget voorstaan (Caforio 2007). Helemaal gelijk krijgt Van Doorn met zijn stelling dat 'roeping' ingewisseld is voor 'beroep' (Moskos 1970) en dat Private Militaire Ondernemingen aan belang hebben gewonnen. Amerikaanse troepen zouden in Irak niet kunnen vechten als zij niet ondersteund 
werden door deze commerciële bedrijven (Singer 2003). Zelf vond Van Doorn (2004) deze ontwikkeling belangrijk genoeg om er een column aan te wijden waarin hij genuanceerd stelling neemt:

Daarmee nemen ze (de burgerhuurlingen, RM) een eigenaardige positie in tussen de militaire en de burgerlijke sector. Hoewel ze in dienst zijn van private ondernemingen, doen ze werk dat normaliter door militairen wordt verricht. Beter gezegd: werd verricht, zoals ik mij herinner uit mijn diensttijd in het naoorlogse Nederlands-Indië. Hun aanwezigheid in het oorlogsgebied zou kunnen duiden op een geleidelijke privatisering van het militaire handwerk. (...) Niet dat de landsverdediging aan bedrijven zou kunnen worden opgedragen. Maar voor zogenaamde vredesoperaties en andere expedities in verre landen zou een (partiële) invoering van de privatiseringsformule best een uitkomst kunnen betekenen.

Figuur 5 Dienstplicht-ratio's ${ }^{6}$

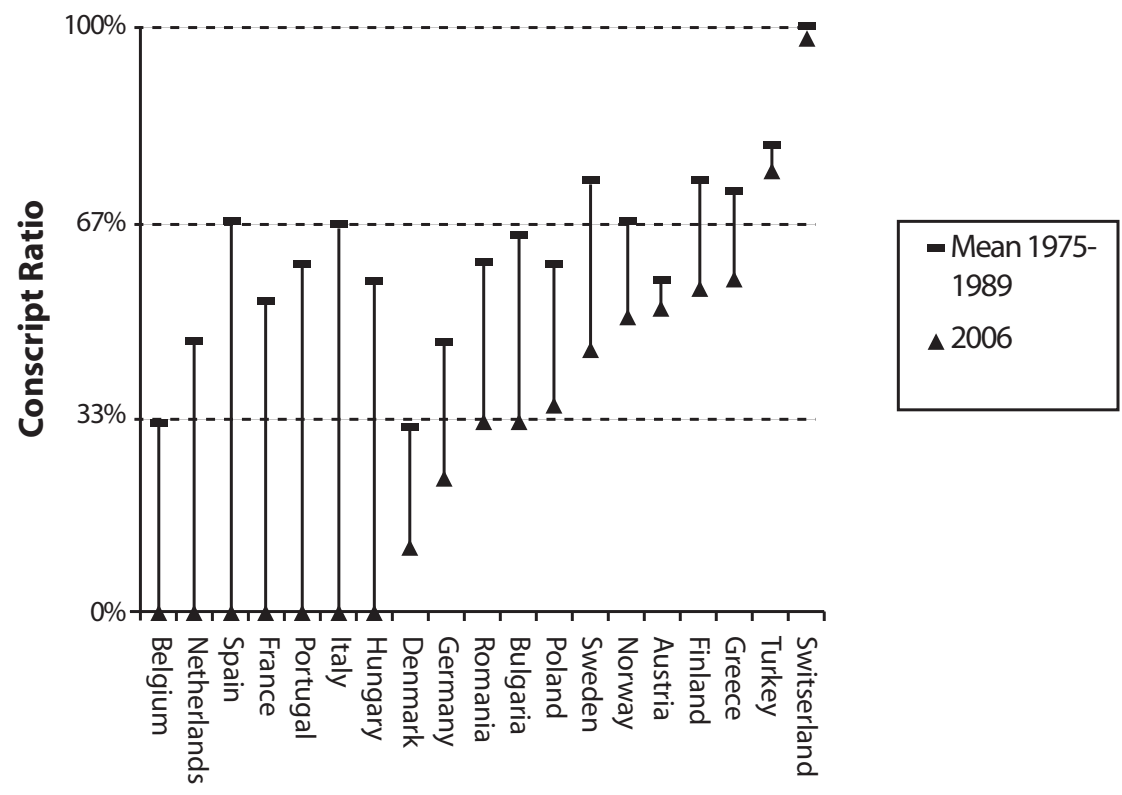

\section{Persoonsvorming en socialisatie in internaatsverband}

Van Doorn is ook wel pleitbezorger geweest van het werk van andere sociologen. In de context van de militaire sociologie is het relevant om te wijzen op de eerste Nederlandstalige uitgave van Erving Goffmans Totale instituties (1975) met een inleiding van Van Doorn. Een tweede druk werd 
later nog ingeleid door de Nederlandse militair sociologen Hans Born en Cas Vroom (1994). De totale instituties zijn door Van Doorn ook aangevat om die zeer bijzondere institutie 'het internaat' te bestuderen en dat binnen de context van elite- en persoonsvorming. Van Doorn heeft rond dat onderwerp in 1965 aan de KMA studiedagen georganiseerd en een conferentiebundel Beroepsvorming in internaatsverband gepubliceerd met daarin niet alleen bijdragen van hemzelf maar ook van Van Hessen en Cor Lammers (Van Doorn 1965).

Militaire academies zijn op enkele uitzonderingen zoals Sandhurst hybride organisaties die het midden houden tussen kazerne en universiteit. Het hybride karakter uit zich in de keuze voor de internaatsformule. Van Doorn (1966: 92) ${ }^{7}$ stelt:

(...) het internaat is een vormingsformule (...) primair een sociale pressure-cooker, en als zodanig ongetwijfeld één van de meest geniale uitvindingen inzake mensenbeheersing. Het isolement van de buitenwereld, de uniformering en indoctrinatie, de voortdurende controle, de geleding in jaarklassen volgens hiërarchisch principe - dit totaal van sociale technieken schept een optimale, in ieder geval een maximale kans tot het kneden van de persoonlijkheid van de leden overeenkomstig de bedoelingen van de leiding.

Goffmans invloed is uiteraard duidelijk herkenbaar. Maar ook interessant is de vergelijking met Foucaults panopticum. Het internaat is een panopticum, maar dan op geraffineerde wijze; het is niet een ruw dwangsysteem zoals een gevangenis, het is, zoals Van Doorn hierboven beweert, 'één van de meest geniale uitvindingen inzake mensenbeheersing'.

In het kielzog van Van Doorn is veel onderzoek gedaan naar persoonsvorming en ook naar de disfuncties van internaatssystemen, de 'secundaire adaptatiepatronen' van Goffman die uiteindelijk tot doelverschuiving zouden leiden. De veronderstelling bij deze adaptatiepatronen is dat het internaatssysteem ook tot persoonsvervorming zou kunnen leiden doordat het mensen tot conformisme dwingt. Je moet niet te veel opvallen, niet te kritisch zijn op het systeem, een beetje gezellig meedoen met sport en sociale activiteiten en niet excelleren bij de studie. De officier die hier het resultaat van zou zijn is een uitvoerder, politiek neutraal, en gezagsgetrouw. Maar geen innovator of vernieuwer en ook geen denker die met nieuwe concepten aan komt zetten. Uit de vele onderzoeken naar persoonsvorming (Burggraaf 1997), blijkt het wel mee te vallen met de doelverschuiving. Na de academie ontwikkelen vele officieren zich immers juist tot uiterst zelfstandige en creatieve denkers die ook bereid zijn hun nek uit te steken als dat nodig mocht zijn (Moelker en Richardson 2002). Zij hebben hooguit voordeel van het sociale en culturele kapi- 
taal dat zij hebben opgedaan tijdens hun internaatsperiode, want niet alleen hebben zij een enorm netwerk rond zich heen gebouwd, maar ook hebben zij een habitus verworven waarmee zij zich kunnen bewegen binnen alle lagen van de wereldbevolking (Moelker en Kümmel 2007).

In het kielzog van Van Doorns onderzoek naar persoonsvorming wordt door de promovendus Jos Schilts onderzoek gedaan naar de restanten van het elitegevoel dat zo'n karakteristieke eigenschap van een internaatssysteem heet te zijn. De conclusie van Schilts is dat cadetten zich wel anders voelen, maar niet per se beter dan de gemiddelde civiele student. Vroeger, en voor het onderzoek heeft Schilts onder andere oudcadetten van vlak na de Tweede Wereldoorlog weten te interviewen, was dat elitegevoel wel degelijk constitutief voor de habitus van de officier in spe. Maar van dit verheven standsbewustzijn is niet veel meer over! Vandaar dat Schilts overweegt om zijn proefschrift met een knipoog naar Johan Huizinga de titel Herfsttij van het elitegevoel mee te geven.

Desondanks zijn er binnen een internaat tradities en disfuncties die discussie kunnen oproepen. Men kan zich afvragen of het efficiënter en effectiever is om academische vorming uit te besteden aan universiteiten, want de organisatievorm waarvoor binnen militaire academies gekozen wordt, leidt per definitie (ook op buitenlandse academies) tot interferentie van belangen: het gaat niet alleen om de vraag of militaire vorming prevaleert boven academische vorming (of omgekeerd), maar ook het cadettencorps als zelfstandige groep van stakeholders speelt mee in het lattenwerk van spanningen dat tezamen de figuratie Nederlandse Defensie Academie vormt. Dit heeft als nadeel een zekere mate van suboptimalisatie, maar als opbrengst moet wederom naar de verworven habitus en het sociale kapitaal worden verwezen: 'Instrumentele vaardigheden zijn (...) ook buiten internaatsverband te verkrijgen' (Van Doorn 1966: 195). In Van Doorns ogen is socialisatie in internaatsverband efficiënter wanneer een organisatie meer normatieve trekken heeft. Dan gaat het namelijk vooral om die socialisatie in normatieve trekken en veel minder om de instrumentele vaardigheden (economie, techniek, geschiedenis, krijgskunde, navigatie en alle andere cognitieve of vaardigheidsaspecten kan men ook buiten het internaat bestuderen). Een normatieve organisatie heeft vooral belang bij de verwerving van 'sociaal-normatieve kwalificaties'. Technisch-instrumentele kwalificaties zijn hieraan ondergeschikt (Moelker 1992). Persoonsvorming is voor een normatieve organisatie belangrijker dan academische vorming.

Van Doorn had dit allemaal zo'n 45 jaar geleden al scherp gezien en wees reeds in het jaar 1966 op 'een crisisgevoel in de bestaande internaten zelf ${ }^{8}$ (1966: 198) en concludeerde ten aanzien van de belangenfiguratie dat het soms belangrijk kan zijn om te veranderen. Maar hij formuleerde deze conclusie zeer omzichtig (Van Doorn 1966: 198): 
Als essentiële doel van het internaat stelden wij het vormen van een corps (bedoeld wordt het officierskorps, RM). (...) Fundamenteel bij de discussie over verandering en voortbestaan van het internaat is (...) het bereiken van de doelstelling: het creëren en continueren van een corps van personen, op het dragen van gezamenlijke verantwoordelijkheid voorbereid. Dit uiteindelijke doel is veel moeilijkheden bij het in stand houden van de internaatsvorming waard. Het doel is echter evenzeer belangrijk genoeg om, waar dit instituut faalt, systematisch nieuwe wegen te zoeken.

Deze discussie wordt nog steeds gevoerd: de rivaliteit tussen universiteit (accreditatieperikelen) en kazerneformule (militaire vorming) wordt gecontinueerd met het cadettenkorps ertussenin, soms als lachende derde, tertius gaudens, soms als lijdend voorwerp vermalen tussen twee krachten. Nieuwe wegen worden geëxploreerd aangezien de NLDA noodzakelijkerwijze kiest voor accreditering als universiteit. De slinger lijkt nu tijdelijk in academische richting te bewegen, maar zoals altijd roept elke beweging een tegenbeweging op en zoekt een slinger altijd een nieuw evenwicht.

\section{Conclusie: er is altijd wel ergens een crisis!}

Wie Van Doorns militaire werk leest komt altijd uit bij de woorden 'crisis' en 'legitimiteit'. Vaak zullen die woorden gebruikt zijn als een stilistische dramatisering bedoeld om de lezer tot een verhoogde attentie uit te nodigen. Maar het gebruik van deze zware woorden is ook een uiting van betrokkenheid. De militaire organisatie, geweldsgebruik en -misbruik, de mens achter 'het' militair, het ging hem allemaal aan het hart. Er zit onmiskenbaar liefde in het militair-sociologische werk van Van Doorn. Het concept crisis heeft ook zijn heuristische waarde, omdat het ons attendeert op veranderingsprocessen, maar het is tegelijkertijd misleidend, omdat er naast discontinuilteit ook continuïteit is. In de kleine halve eeuw waarin Van Doorn militair-sociologische onderzoeken te boek stelde, heeft hij continu de veranderingen in kaart gebracht, deze dramatisch presenterend als telkens weer een nieuwe crisis en daarbij kwamen de constanten en de overlevingskunst van de organisatie veel minder aan bod. Hij had ook de basismechanieken die ten grondslag lagen aan de fusie van professie en organisatie (zie Sociologie van de organisatie uit 1956) verder kunnen uitwerken en laten zien hoe juist deze mechanieken als onderliggende constanten de dynamiek van verandering in gang zetten. Het werk van Norbert Elias zoals onder andere beschreven in The Genesis of the Naval Profession (2007) vormt een voorbeeld waar vanuit de constante basisspanningen tussen zeilers en vechters een 
transformatieproces tot stand komt dat tot het beroep van zeeofficier leidt. Van Doorns Sociologie van de organisatie bevat dezelfde analytische belofte, maar die wordt helaas niet waargemaakt in het verdere werk dat van crisis naar crisis rolt.

Van Doorn behoort tot de wetenschappelijke canon binnen de militaire sociologie. Velen zullen erkennen dat zij intellectueel schatplichtig aan Van Doorn zijn, al was het maar omdat de militair-sociologische traditie bij Van Doorn aanvangt en omdat zovele hypotheses nog steeds het uitgangspunt voor empirisch onderzoek zijn. Ook de noviet in de militaire sociologie ontdekt al snel dat er voorgangers waren die de meest wezenlijke van de militair-sociologische vragen al hebben gesteld. Van Doorn is daarmee binnen de Nederlandse traditie het startpunt voor militair-sociologische analyses en de reus op wiens schouders wij graag staan om verder te kunnen kijken, maar internationaal zal hij toch wel snel vergeten worden, want behoudens enkele chroniqueurs van het Inter-university Seminar en ISA Research Committee 01 on Armed Forces and Conflict Resolution kent de jongere generatie buitenlandse militair sociologen Van Doorn niet meer, en dat is ook begrijpelijk aangezien hij toch voornamelijk in het Nederlands publiceerde.

In het onderwijs aan toekomstige officieren leeft de geest van Van Doorn wel degelijk voort. In een publicatie 'Van Doorn and Beyond' in het mede door Van Doorn opgerichte Armed Forces and Society betogen Moelker en Soeters (2008) dat vooral het probleemgeoriënteerde sociologieonderwijs aan de Nederlandse Defensie Academie een regelrecht uitvloeisel is van de beleidsgeoriënteerde aanpak die Van Doorn altijd heeft voorgestaan. Theorie hoeft niet geschuwd te worden, maar het moet wel altijd gaan om concrete maatschappelijke problemen, zowel als onderzoekskeuze als onderwijsdidactiek. Toekomstige officieren zijn pragmatisch en pas dan in theorie geïnteresseerd als zij zien hoe deze kan helpen bij het oplossen van actuele problemen. In het onderwijs over 'normvervaging' wordt een samenvattend hoofdstuk over Ontsporing van geweld nog altijd gebruikt, omdat het juist vandaag de dag relevant is voor counter-insurgency operaties. Een ander voorbeeld van beleidsgerichte/probleemgerichte sociologie dat Van Doorn zou toejuichen en dat in de officiersopleiding ondertussen een vast plaatsje gevonden heeft is het werk van Cor Lammers (2010) over bezettingsmachten. De vraag welke stijl van bezetten nu effectief is en hoe culturele variaties daarin hun rol spelen is voor officieren in spe uiterst interessant. Het werk van de meeste militair sociologen is net zo min als Van Doorns beleidssociologie freischwebend, maar wel een intelligente wijze van probleembenadering.

Van Doorn heeft altijd zijn interesse voor de militaire organisatie en vooral voor militairen zelf behouden. Dat geldt heel specifiek voor oud- 
militairen, de veteranen van bijna vergeten missies. Van Doorn (2006b) stak zijn waardering voor veteranen niet onder stoelen of banken en hij formuleerde deze dan ook op een wijze die voor hem als mens kenmerkend is:

We zijn meer dan zestig jaar 'in een negatief daglicht gesteld', terwijl we 'in een rotzooi terecht waren gekomen waarin we niet konden slagen'. Het wordt naar mijn mening dan ook hoog tijd ons een onderscheiding toe te kennen, geen ordinair 'draaginsigne', maar een hoge militaire onderscheiding, zo mogelijk vergezeld van een fatsoenlijke som smartengeld. Wel opschieten graag, anders zijn er geen Indië-veteranen meer over.

\section{Noten}

1. Bron: De Gheyn (1971 [1607]).

2. Van Doorn verwijst naar een artikel van Moskos uit 1973, maar laatstgenoemde heeft het thema van de verandering van instituut naar beroep (occupation) in talloze andere publicaties verder uitgewerkt (zie onder andere Moskos 1970). Deze analyse is zodanig bekend dat militair sociologen zonder referentie kunnen verwijzen naar het I-O model om begrepen te worden.

3. Van Doorn schrijft nergens letterlijk dat de gevechtskracht afneemt. Hij was in zijn wetenschappelijke werk te voorzichtig om dergelijke politiek gevoelige taal te bezigen, maar hij impliceert zo'n afname wel en spreekt wel over de camouflage van de geweldsfunctie van de krijgsmacht.

4. Bron: http://www.nato.int/issues/women_nato/perc_fem_soldiers_2001_2006.pdf \&:http://www.nato.int/issues/women_nato/perc_fem_soldiers_2007.pdf;bij civiele arbeidsdeelname wordt gerekend met een minimumdeelnamevan één uur aan het arbeidsproces. Bron: http://www.cbs.nl/nl-NL/menu/themas/dossiers/vrouwen-enmannen/publicaties/publicaties/archief/2009/emancipatie-2008-pub1.htm; Merens en Hermans (2009: 108).

5. Van Doorns artikel 'The Decline of the Mass Army' (1975c), verschenen in Armed Forces and Society, is integraal opgenomen in dit boek (1975a). Het citaat kan men dan ook in beide publicaties terugvinden.

6. Bron: Haltiner en Szvircsev Tresch (2008).

7. Van Doorns werk is vaak op meerdere plaatsen gepubliceerd. Het hoofdstuk waar het hier om gaat is ook verschenen in Van Doorn (1965).

8. Als dit een crisisgevoel zou moeten zijn, dan is de KMA/KIM/NLDA nooit aan dit crisisgevoel ontstegen. Van Doorn zit er hier helemaal naast. De spanningen aan deze militaire academies (ook de buitenlandse) vormen een constante en zijn juist door middel van dialectische mechanismen constitutief voor de persoonsvorming van officieren. Het is juist datgene wat meerwaarde opbrengt ten opzichte van universiteiten, wat bijdraagt aan de vorming van een unieke habitus. Van Doorn heeft de altijd aanwezige spanningsrelatie onjuist geïnterpreteerd als 'crisis'. Het opleidingssysteem verandert uiteraard over de tijd, maar de spanningen blijven en vormen de meerwaarde van het internaatssysteem. 


\section{Geraadpleegde literatuur}

Abrahamsson, B. (1972), Military Professionalization and Political Power, Beverly Hills: Sage.

Brentjens, H.J.H. en Ch. F. Turpijn (1977), Welzijn en krijgsmacht, Deventer: Van Loghum Slaterus.

Burggraaf, W. (1997), 'Management Skills from Different Educational Settings', International Journal of Educational Management 11: 65-71.

Burk, J. (1993), 'Morris Janowitz and the Origins of Sociological Research on Armed Forces and Society', Armed Forces and Society 19: 167-185.

Caforio, G. (2007), Cultural Differences between the Military and Parent Societies, Amsterdam: Elsevier.

Carreiras, H. (2006), Gender and the Military: Women in the Armed Forces of Western Democracies, Londen: Routledge.

Creveld, M. van (2001), Men, Women and War, Londen: Cassell.

Creveld, M. van (2008), The Culture of War, New York: Presidio Press.

Doorn, J.A.A. van (1948), 'De crisis van het militarisme', Mens en maatschappij 23: 286-318.

Doorn, J.A.A. van (1956), Sociologie van de organisatie. Beschouwingen over organiseren in het bijzonder gebaseerd op een onderzoek van het militaire systeem, Leiden: Stenfert Kroese.

Doorn, J.A.A. van (1965), 'De creatie van een korps: De actualiteit van een oude formule', in: J.A.A. van Doorn (red.), Beroepsvorming in internaatsverband. Sociologische beschouwingen en specifieke ervaringen, Rotterdam: Universitaire Pers, p. 66-81.

Doorn, J.A.A. van (1966), Organisatie en maatschappij, Leiden: Stenfert Kroese.

Doorn, J.A.A. van (1975a), The Soldier and Social Change. Comparative Studies in the History and Sociology of the Military, Beverly Hills: Sage.

Doorn, J.A.A. van (1975b), 'The Military and the Crisis of Legitimacy', in: The Soldier and Social Change. Comparative Studies in the History and Sociology of the Military, Beverly Hills: Sage.

Doorn, J.A.A. van (1975c), 'The Decline of the Mass Army in the West. General Reflections', Armed Forces and Society 1: 147-158.

Doorn, J.A.A. (1977), 'De krijgsmacht in de verzorgingsstaat', in: H.J.H. Brentjens en Ch.F. Turpijn (red.), Welzijn en krijgsmacht, Deventer: Van Loghum Slaterus, p. 33-43.

Doorn, J.A.A. (1977), 'Voortgaande vermaatschappelijking of hernieuwde militarisatie?', in: H.J.H. Brentjens en Ch.F. Turpijn (red.), Welzijn en krijgsmacht, Deventer: Van Loghum Slaterus, p. 84-91.

Doorn, J.A.A. en C.J.M. Schuyt, (1978), De stagnerende verzorgingsstaat, Meppel: Boom.

Doorn, J.A.A. van (2004), 'Burgerhuurlingen', HP/De Tijd, week 2.

Doorn, J.A.A. van (2006a), 'Kop in het zand', HP/De Tijd, week 13. 
Doorn, J.A.A. van (2006b), 'Veteranenleed', HP/De Tijd, week 46.

Doorn, J.A.A. (2007a), Duits socialisme. Het falen van de sociaal-democratie en de triomf van het nationaal-socialisme, Amsterdam: Mets \& Schilt.

Doorn, J.A.A. van (2007b), 'Het gaat mis in Afghanistan', Trouw, 21 april 2007.

Doorn, J.A.A. van (2007c), 'Oorlog als wetenschappelijk thema', Trouw, 13 juli 2007.

Doorn, J.A.A. (2009), Nederlandse democratie. Historische en sociologische waarnemingen, Amsterdam: Mets \& Schilt.

Doorn, J.A.A. van en W.J. Hendrix (1970), Ontsporing van geweld. Over het Nederlands/Indisch/Indonesisch conflict, Rotterdam: Universitaire Pers.

Elias, N. (2007), The Genesis of the Naval Profession, Dublin: University College Dublin Press.

Gheyn, J. de (1971 [1607]), Wapenhandelinghe van roers, musquetten ende spiesen, Lochem: De Tijdstroom.

Goffman, E. (1975), Totale instituties, Rotterdam: Universitaire Pers.

Goffman, E. (1994), Totale instituties (tweede druk), Rotterdam: Universitaire Pers.

Haltiner, K.W. (1998), 'The Definite End of the Mass Army in Western Europe', Armed Forces and Society 25: 7-36.

Haltiner, K. en T. Szvircsev Tresch (2008), 'European Civil-Military Relations in Transition. The Decline of Conscription' in: G. Caforio, G. Kümmel en B. Purkayastha (red.), Armed Forces and Conflict Resolution. Sociological Perspectives, Bradford: Emerald, p. 165-182.

Homans, G.C. (1946), 'The Small Warship', American Sociological Review 11: 294-300.

Janowitz, M. (1960), The Professional Soldier, New York: Free Press.

Klinkert, W. (2003), Studeren in uniform, Den Haag: Sdu.

Lammers, C.J. (2010), 'The American Occupation Regime in Comparative Perspective. The Case of Iraq', Armed Forces and Society 35 (in druk).

Merens, A. en B. Hermans (red.) (2009), Emancipatiemonitor 2008, Den Haag: SCP/CBS.

Merton, R.K. (1967), Social Theory and Social Structure, New York: Free Press.

Meulen, J. van der en Ph. Manigart, (1997), 'Zero Draft in the Low Countries: The Final Shift to the All-volunteer Force', Armed Forces and Society 24: 315-332.

Moelker, R. (1992), Zou hij onze nieuwe werknemer kunnen zijn? Veranderingen in gevraagde kwalificaties als weerspiegeling van veranderingen in de betekenis van prestatie. Een inhoudsanalyse van personeelsadvertenties, De Lier: Academisch Boeken Centrum.

Moelker, R. en J. Bosch (2008), Hidden Women, Breda: Nederlandse Defensie Academie. 
Moelker, R. en G. Kümmel (2007), 'Chivalry and Codes of Conduct. Can the Virtue of Chivalry Epitomize Guidelines for Interpersonal Conduct?', Journal of Military Ethics 6: 292-302.

Moelker, R. en R. Richardson (2002), 'Socialisatie op de KMA', in: R. Richardson, D. Verweij, A. Vogelaar en H. Kuipers (red.), Mens en organisatie. De krijgsmacht in verandering, Amsterdam: Mets \& Schilt, p. 59-77.

Moelker, R. en J. Soeters (2008), 'Van Doorn and Beyond. From Teaching Sociology to Interdisciplinary, Problem-based Learning in Dutch Officer Training', Armed Forces and Society 35: 36-48.

Moskos, C.C. (1970), The American Enlisted Man. The Rank and File in Today's Military, New York: Russell Sage Foundation.

Moskos, C.C. (1973), 'The Emergent Military. Civil, Traditional or Plural?' Pacific Sociological Review 16: 267-271.

Oosterhuis, G. (1993), Promotie. Een empirisch onderzoek naar de loopbanen van marineofficieren in de twintigste eeuw, Den Helder: Koninklijk Instituut voor de Marine.

Richardson, R., J. Bosch en R. Moelker (2007), 'Diversity in the Dutch Armed Forces', in: J. Soeters en J. van der Meulen (red.), Cultural Diversity in the Armed Forces, Londen: Routledge, p. 200-214.

Shils, E. en M. Janowitz (1948), 'Cohesion and Disintegration in the Wehrmacht in World War II', Public Opinion Quarterly 12: 280-315.

Singer, P. (2003), Corporate Warriors. The Rise of the Privatized Military Industry, Londen: Cornell University Press.

Stouffer, S. et al. (1950), The American Soldier. Adjustment During Army Life, New York: Science Editions. 



\title{
8 Sociologen en de krijgsmacht
}

\author{
Een gespannen verhouding
}

Casper W. Vroom

J.A.A. van Doorn werd bij de invoering op de Koninklijke Militaire Academie van de zogenaamde wetenschappelijke studie in 1962 de eerste (buitengewone) hoogleraar militaire sociologie. In die periode was hij buitengewoon productief met analyses van allerlei aard over de verschillen tussen militaire en industriële organisatie, de vorming van het officierskorps, de verhouding tussen krijgsmacht en politiek. Toen ik in 1983 op de KMA als gewoon hoogleraar de leerstoel (organisatie)sociologie ging bekleden, kwam ik daarmee op een bijzondere plaats terecht. Ik heb heel wat van Van Doorn gelezen, uit die tijd en van later. Bij deze gelegenheid is dat aanleiding om eens stil te staan bij de gespannen verhouding tussen sociologen en de krijgsmacht. Hoe moet je je als wetenschapsbeoefenaar opstellen als je gekozen hebt voor een tamelijk gulzige institutie, in dit geval de krijgsmacht? Zo'n reflectie is niet zonder zin, want ze gaat over de kern van de verhouding tussen onderzoeker en het onderzochte, dus hier over de verhouding tussen onderzoeker en organisatie.

Volgens mij zijn er twee extreme posities in deze verhouding met de mogelijkheid van een (nuttige) tussenpositie. Mijn keuze is dus al duidelijk. De eerste positie is die van de kritische distantie. Mijns inziens was Van Doorn altijd geporteerd voor deze stellingname. De onderzoeker dient zich volstrekt onafhankelijk op te stellen en wil op geen enkele wijze deel uit maken van de interne werkelijkheid van de onderzochte organisatie, en dat zeker niet in ethische zin. Hij wil zijn handen schoon houden. Hij wenst zo objectief mogelijk organisatorische verschijnselen te onderzoeken en te beschrijven. Dat hij vervolgens daar een mening over heeft is zijn goed recht. Door zijn kritische en intelligente analyses is hij in staat te wijzen op ontwikkelingen en verbanden waar anderen (en zeker de leden van de betrokken organisatie) steeds aan voorbij zijn gegaan of juist willen gaan. De vraag is dan nauwelijks van belang of je 
iets praktisch kunt met deze kennis en inzichten. Dat is een probleem voor anderen dan de scherpe analyticus/intellectueel. Op het niveau van het maatschappelijk debat levert het werk van deze mensensoort nuttige resultaten op. Ik denk dat Van Doorn gedurende heel zijn leven dit adagium heeft proberen waar te maken.

De tweede extreme positie is die van de volstrekte vereenzelviging. Dan is de onderzoeker mentaal (en meestal ook in de zakelijke werkelijkheid) in dienst van de betrokken organisatie. Zijn keuzes zijn in hoofdzaak die van de leiding. Hij levert feiten en methoden om de besturing van de organisatie te vergemakkelijken. Hij is als het ware one of the boys. Dat wil niet zeggen dat het onzin is wat hij denkt of schrijft, maar het is altijd gekleurd en ingegeven door de ideologie van de betreffende club. Twee voorbeelden om de gedachten te bepalen: het KASKI en de MPSD. Het eerste, het Katholiek Sociaal Kerkelijk Instituut, was een verzameling sociale wetenschappers in dienst van de Katholieke Kerk, een organisatie met een krachtige hiërarchie die al snel had ingezien dat men het kerkvolk beter geestelijk kon 'richten' als er allerlei vooral sociografische gegevens beschikbaar waren. De tweede, de Militair Psychologische en Sociologische Dienst, is onderdeel van Defensie en stelt zich tot taak sociaal-wetenschappelijke kennis te ontwikkelen en beschikbaar te maken voor de krijgsmacht. Dat levert interessante en nuttige inzichten op, over de ontkerkelijking van Nederland en over de omgang met posttraumatische stressstoornissen. Maar het mag duidelijk zijn dat dit een volstrekt andere positie is dan de eerste.

Volgens mij is er nog een tussenpositie denkbaar. Ik sluit me dan aan bij de methodologische opvattingen van Max Weber. Betrokkenheid bij de mensen, hun doelen en hun gedrag, zeker in het geval van bijzondere of extreme organisaties zoals de krijgsmacht, is noodzakelijk, omdat men anders geen toegang krijgt tot de binnenkant van zo'n organisatie, de eigen manier waarop men daar zijn werkelijkheden schept en die met elkaar hanteert, de subjektiv gemeinter Sinn van Weber. Dat impliceert niet dat men Faust is geworden en zijn ziel aan de duivel heeft verkocht. Het houdt wel in dat de onderzoeker gericht is op een zo scherp mogelijke analyse van de sociale werkelijkheid zoals die door de deelnemers eraan wordt gemaakt en beleefd. Tegelijkertijd tracht de onderzoeker dezelfde deelnemers een spiegel voor te houden waarin zij zichzelf kunnen herkennen en waardoor zij tot nieuwe inzichten kunnen komen. Max Weber zou dat het spanningsveld tussen Entzauberung en Rationalisierung noemen. Deze positie zou men als betrokken distantie kunnen betitelen - ik heb altijd geprobeerd zo het dilemma van de ochtendmens en de avondmens op te lossen dat Cor Lammers in zijn bijdrage aan deze bundel heeft beschreven. 
Voor mij is volstrekt duidelijk dat J.A.A. van Doorn nooit heeft gekozen voor volstrekte vereenzelviging, misschien heel soms voor betrokken distantie, maar vrijwel altijd en zeker voor kritische distantie en dat hij met een onmiskenbaar sardonisch genoegen bezag hoe mensen op zijn scherpe en soms pijnlijke commentaar wensten te reageren. Het is goed dat er in het huis van de sociologie vele kamers zijn. Van Doorn was een groot socioloog. 



\title{
9 De fuik van militaire avonturen
}

\author{
Indië, Bosnië, Afghanistan
}

Jan van der Meulen

\section{Inleiding}

Op 19 januari 2008 publiceerde J.A.A. van Doorn een essay in NRC Handelsblad, dat als kop meekreeg: 'In de fuik van een gewelddadig avontuur met neokoloniale ambities'. Dat essay ging over Uruzgan, over Afghanistan, over wat Van Doorn de derde ronde in de strijd om Azië noemt. De eerste ronde betrof de dekolonisatieoorlogen, de tweede de extreem gewelddadige uitwassen van de Koude Oorlog in Vietnam en Afghanistan, op conto van respectievelijk de Verenigde Staten en de Sovjet-Unie. En nu, aldus Van Doorn, heeft zich een westers offensief ontrold in de islamitische wereld, dat opnieuw tegen het historische tij ingaat en dat, naarmate het langer duurt, alleen maar meer verzet oproept.

Nederland maakt deel uit van dat offensief, zegt hij, ongeacht de eigen bedoelingen en ongeacht de plaatselijk bewerkstelligde resultaten. Over die laatste toont Van Doorn zich sowieso sceptisch - onveiligheid doorkruist wederopbouw - maar in feite is dat niet beslissend. De fuik waar Nederland in zit is veel groter dan de eigen politieke en militaire onmacht: 'We kunnen zoveel waterputten slaan en basisscholen opverven als we willen, het zal ons niet helpen ons vrij te pleiten van betrokkenheid bij een gewelddadig avontuur waarvan we de ernst en de reikwijdte nooit hebben beseft.'

Van Doorn was niet de enige die zich sceptisch toonde over de zin van de strijd in Afghanistan en over de kans op een succesvolle afloop. In het koor van critici was zijn stem echter gezaghebbend en herkenbaar. Gezaghebbend omdat hij een groot overzicht van de mondiale geschiedenis van samenlevingen combineerde met een diepgaand sociologisch begrip van de dynamiek van gewelddadige conflicten en van het functioneren van militaire organisaties. Herkenbaar omdat hij ook bij eerdere militaire interventies, steevast aangeduid als 'avonturen', weinig 
vertrouwen had in de haalbaarheid ervan - de graag gebruikte metafoor van de 'fuik' was veelzeggend genoeg. Daarbij fungeerde het conflict dat Van Doorn zelf als dienstplichtig militair meemaakte en later als socioloog analyseerde, vaak als referentiepunt en parallel. Zo ook in het essay over hoe Nederland politiek en militair verstrikt raakte in Uruzgan: 'Ruim een halve eeuw geleden, in de periode 1945-1949, overkwam ons hetzelfde, zij het in een honderdvoudige vergroting' (Van Doorn 2008).

In dit hoofdstuk wil ik een aantal typerende observaties van Van Doorn over hedendaagse militaire missies nader onder de loep nemen. Wat is nu precies de kern van zijn consequente en scherpe kritiek? Wat is de zeggingskracht van de steeds weer terugkerende vergelijking met de strijd in Nederlands-Indië? Want dat er naast treffende overeenkomsten ook belangrijke verschillen in het geding zijn tussen toen en nu, realiseerde Van Doorn zich zelf uiteraard ook. Vaak genoeg legde hij de vinger op veranderingen in oorlogvoering, in militaire organisatie, in politiek-maatschappelijke verhoudingen. Maar wat is dan per slot van rekening zijn visie op de mogelijkheid en de moraliteit van militaire geweldstoepassing, wanneer die kennelijk keer op keer vastloopt in een fuik, tegenwoordig evenzeer als vroeger?

Ik zoek een antwoord op die vragen in de columns en essays die Van Doorn schreef over de gewelddadige conflicten van na de Koude Oorlog, waarbij het tot militair optreden van buitenaf kwam. Daarbij zal het in het bijzonder gaan om zijn analyses van de interventie in Bosnië, waarin Nederland zo'n dramatische rol speelde en om die van de oorlog in Afghanistan, onverminderd actueel twee jaar nadat Van Doorn zijn laatste essay erover schreef. Maar alvorens op Bosnië en Afghanistan in te gaan, pak ik de studie erbij die Van Doorn samen met W.J. Hendrix publiceerde over wat Nederland tussen 1945 en 1950 overkwam, toen het de strijd aanbond met de nieuw geproclameerde Republiek Indonesië. Juist ook omdat Van Doorn zelf zo vaak de vergelijking met dit conflict trok, ligt het voor de hand Ontsporing van geweld, zoals de eerste druk van het boek heette, na te pluizen op bevindingen en inzichten die zijn stellingname inzake recente militaire avonturen kunnen verhelderen en verdiepen. Aldus, achtereenvolgens, parafraserend en citerend, de fuik van Indië, de fuik van Bosnië en de fuik van Afghanistan. Ik vlecht er commentaar tussendoor dat toewerkt naar de beantwoording van de zojuist gestelde vragen in een slotbeschouwing. ${ }^{1}$

\section{De fuik van Indië: ontsporing van geweld}

Het verhaal achter Ontsporing van geweld (Van Doorn en Hendrix 1983) is inmiddels vaak verteld, het meest grondig en ook kritisch door Stef Scagliola (2002: 202-211). De studie werd gepubliceerd in 1970 en bevatte 
de resultaten van onderzoek dat de beide auteurs op eigen initiatief hadden verricht, toen ze als dienstplichtigen de strijd in Nederlands-Indië van binnenuit meemaakten. Aanleiding om twintig jaar later tot publicatie over te gaan vormde de nationale beroering die was ontstaan over destijds door Nederlandse militairen gepleegde oorlogsmisdaden. Dat woord werd door Van Doorn en Hendrix vermeden en vervangen door de officieel in zwang geraakte term 'geweldsexcessen', afgewisseld met 'militaire excessen'. Dat paste bij de doelstelling van het boek, die in het voorwoord luidt: 'verklaren, niet beschuldigen; een zakelijke analyse, geen emotionele reactie' (1983: 16).

In datzelfde voorwoord noemen Van Doorn en Hendrix hun boek een 'sociale geschiedenis van militair geweld' (idem: 16). De notie van een geweldsfuik vormt daarin het sluitstuk van een analyse die op verschillende, in elkaar grijpende niveaus, de krachtmeting uiteenrafelt die zich van 1945 tot 1950 in Nederlands-Indië tussen Nederland en Indonesië afspeelde. Als uitkomst van een historisch gegroeid koloniaal conflict, als machtsspel tussen meerdere partijen, groeperingen en belangen, als botsing tussen ongelijksoortige militaire organisaties en formaties en als daadwerkelijke aanwending van geweld. Dat alles ten slotte uitmondend in de casestudy van één bepaalde compagnie, waarover de auteurs systematisch data hadden verzameld, toegespitst op excessen: het in brand steken van kampongs, het martelen om informatie te verkrijgen, het doden van krijgsgevangenen en burgers.

Dergelijke geweldsontsporingen spelen zich af in de diepte van de fuik, diep in termen van de organisatie, de operatie, het proces. Dáár ergens worden vuile handen gemaakt, door speciale troepen, door inlichtingendiensten, maar ook, onder omstandigheden, door gewone soldaten in een gewone compagnie. Door Van Doorn en Hendrix wordt heel precies uitgelegd waarom 'bevel is bevel', en 'situatiedwang' tekortschieten om geweldsontsporingen te verklaren en te begrijpen (idem: 231). $\mathrm{Er}$ is een bredere blik nodig op de 'verzelfstandiging van de geweldsorganisatie' (idem: 218), en op wat het betekent wanneer in een dergelijk conflict, guerilla-achtig aan de ene kant, als politieel gedefinieerd aan de andere kant, militairen de ruimte krijgen en nemen.

Die militairen zelf waren heel divers, niet alleen conform de functionele indelingen van de krijgsmacht, maar ook op het snijvlak van professionele houding en psychologische identificatie. Met als grote, te onderscheiden categorieën, de mannen die tot het KNIL behoorden (Koninklijk Nederlands Indisch Leger), de oorlogsvrijwilligers en de dienstplichtigen. De vrijwilliger in het bijzonder, aldus Van Doorn en Hendrix (idem: 160), stond voor de 'soldaat als kind van zijn tijd en die tijd was de Tweede Wereldoorlog'. 
Vooral de OVW-ers, die met groot enthousiasme bij tienduizenden dienst hadden genomen, kwamen voort uit een generatie, welke geweld en repressie aan den lijve had gevoeld en welke de soldaten van de bevrijdingslegers als een sociaal succes had leren bewonderen. In die tijd was de soldaat populair, niet alleen omdat hij aan de bezetting een einde had gemaakt, maar ook in een veel diepere psychische laag: als symbool van macht, prestige, vrijheid, mannelijkheid en agressie.

Juist deze soldaten, schrijven Van Doorn en Hendrix, dachten als bevrijders te worden onthaald, maar werden van meet af aan als bezetters bejegend. Wat was begonnen en werd gerechtvaardigd als een 'kolossale humanitaire missie' (idem: 124) sloeg om in haar tegendeel. Toen de grote massa van dienstplichtigen nog moest komen, hadden de oorlogsvrijwilligers van het eerste uur hun ontnuchterende ideologische vuurdoop al ondergaan. 'Reeds op die eerste dag stond de geweldsfuik voor het Nederlandse leger - onzichtbaar nog - wijd open. De stroom van rationalisaties kon beginnen te vloeien, in een wanhopig zoeken naar rechtvaardiging van wat men aan geweld zou gaan gebruiken' (idem: 270).

Nederland was niet het enige land dat in een dergelijke fuik belandde. In een extra hoofdstuk, toegevoegd in de tweede druk van hun boek - nieuwe hoofdtitel: 'Het Nederlands/Indisch/Indonesisch conflict' schetsen Van Doorn en Hendrix de grote historische trend van de dekolonisatie, in Azië en Afrika. Ze zetten dan het conflict dat tussen Nederland en Indonesië werd uitgevochten naast de confrontaties waarmee de ontbinding van andere koloniale imperia gepaard ging: het Britse, het Franse, het Portugese. Zeker in vergelijking met die beide laatste landen blijken de geweldstoepassing en geweldsontsporing door toedoen van de militaire inzet van Nederland in Indonesië, relatief beperkt en beheerst. Ook daarvoor worden precieze verklaringen geboden in termen van koloniale constellaties, militaire culturen en politieke processen, nationaal en internationaal. Want al deze conflicten raakten vervlochten met ontwikkelingen in de Koude Oorlog en de machtsstrijd tussen de SovjetUnie en de Verenigde Staten.

De oorlog die de Amerikanen zelf in Vietnam voerden wordt ook in deze vergelijking betrokken. Postkoloniaal weliswaar, maar passend 'in de serie van grote gewelddadige conflicten tussen een Westerse militaire macht en een inheemse verzetsbeweging. In Vietnam herhaalde zich op zeer vergrote schaal het geweld dat eerder door Nederlanders in Indonesië was toegepast'. Bovendien was het juist de maatschappelijke beroering rond de excessen van Vietnam, die ook in andere landen oude wonden openreet. Alom ontploften 'publiciteitsbommen' over eigen 'oorlogsmisdaden', die lang waren afgeschermd en toegedekt. Maar in 
Vietnam, de 'eerste TV-oorlog', bleek dat niet langer mogelijk en zo kwamen, met terugwerkende kracht, ook de ontsporingen van eigen soldaten in het brandpunt van het publieke debat (idem: 21-49).

Dat in Nederland pas via Vietnam publieke beroering over de gepleegde geweldsexcessen ontstond, verklaren Van Doorn en Hendrix in het nawoord van hun boek uit een algemeen patroon met betrekking tot de 'maatschappelijke omgang met geweld': 'Men zoekt de confrontatie met geweld te ontvluchten door de verantwoordelijkheid van het gebruik ervan eenvoudig te delegeren aan specialisten.' Dat patroon, aldus Van Doorn en Hendrix, komt neer op een 'kolossaal afwentelingsproces'. De burger wendt de blik af en de militair zelf doet er, althans in het openbaar, het zwijgen toe. Jaren later komt de regering met een Excessennota die de pijnlijke vraag naar de toedeling van verantwoordelijkheid ontwijkt, terwijl toch als bestuurlijk axioma geldt dat 'vooraan in de keten van oorzaak en gevolg, die hier een relatie is tussen daad en schuld, de politieke leiders (staan), de enigen die in onze maatschappij gerechtigd zijn om het gebruik van geweld te doen organiseren en te doen toepassen' (idem: 325-329).

Dat organiseren en toepassen van geweld deden politieke leiders destijds echter wel, zo memoreren Van Doorn en Hendrix, met instemming van de (grote) meerderheid van de Nederlandse bevolking. Die steunde de strijd tegen Indonesië, tot en met de tweede politionele actie toe. De auteurs herinneren eraan dat ook de pers, haantje de voorste toen in 1969 de publiciteitsbom barstte, 'destijds in meerderheid partij gekozen (had) voor het Indië-beleid en consequent verzuimd (had) de vinger aan de pols te houden' (idem: 326-327). Maar er waren ook tegengeluiden die een stempel op de stemming drukten en die invloed hadden op een deel van de uit te zenden dienstplichtige militairen. 'Zij staan onder druk van een deels afwijzende publieke opinie - compleet met stakingen in de havensteden - en zij zijn zelf evenmin geneigd het avontuur zonder meer te accepteren.' Weigeraars waren niet ongewoon maar de grote massa van dienstplichtigen liet zich toch gemotiveerd en wel inschepen (idem: 177-178). Na aankomst werden ze verwelkomd met retorische hoogstandjes over wat zij gingen doen: 'De bevolking van terreur bevrijden - deze stelling is in honderd varianten uitgewerkt' (idem: 125). Van Doorn en Hendrix waren erbij, namen waar wat er gebeurde en verklaarden later hoe dit militaire avontuur kon mislukken en ontsporen.

\section{Commentaar}

Door H. Schijf is in het aan Van Doorn gewijde herdenkingsnummer van Mens en maatschappij opgemerkt dat het boek van Van Doorn en Hendrix 'nauwelijks gedateerd' is. 'Integendeel, ontsporing van geweld is ook 
in 2008 in veel regio's op de wereld de gruwelijke werkelijkheid.' Dat is ongetwijfeld waar, al kunnen daarbij natuurlijk heel verschillende oorzaken in het geding zijn - mislukte staten, florerend gangsterdom, ideologisch extremisme - die om andere verklaringen vragen. Niet al het moorden en martelen op deze wereld en niet al het verkrachten en verminken kan worden toegeschreven aan de ontsporing van geregelde legers die als bezettingsmacht opstandelingen moeten bestrijden. En dat is uitdrukkelijk het historische en analytische raamwerk dat door de auteurs gebruikt wordt. Terecht wijst Schijf er in dat verband op dat Van Doorn en Hendrix de destijds gevoerde oorlog als 'asymmetrisch' benoemen. Ook dat begrip is onverminderd actueel (Schijf 2008: 210-212).

Hun studie wordt, als gezegd, door beide auteurs gepresenteerd als een 'sociale geschiedenis van geweld', vermoedelijk vooral ter onderscheiding van politieke en militaire geschiedenis. Die beide invalshoeken zitten er toch ook wel in, zij het de tweede een stuk sterker dan de eerste. Van de latere 'echte' militaire geschiedenisschrijving hebben Van Doorn en Hendrix overigens op belangrijke punten gelijk gekregen (Groen 1991). In plaats van een 'sociale geschiedenis' is het misschien toepasselijker om van een maatschappijgeschiedenis te spreken, omdat dan nog beter de reikwijdte en spanbreedte van het gehanteerde perspectief uitkomen. Het is bij uitstek een historisch-sociologische studie die de verwevenheid van micro met macro laat zien, de vervlechting van individuen in groepen en organisaties met institutionele en (inter)nationale machten en krachten. Toegepast op het Nederlands-Indonesisch conflict ontvouwt zich aldus het proces van een land dat in een geweldsfuik terechtkomt, waardoor politieke oplossingen worden belemmerd en militaire ontsporingen worden bevorderd.

Dat was natuurlijk niet de uitkomst die de betrokkenen voor ogen hadden. Hun bedoelingen en verwachtingen waren anders en dat gold voor de politieke leiders en de militaire commandanten evenzeer als voor de burgers en de soldaten. Juist die discrepantie tussen rechtvaardigende retoriek en ontnuchterende realiteit bleef laatstgenoemden levenslang bij. Hun vorming als 'generatie' door deelname aan een 'unieke' historische gebeurtenis, zo schreef Van Doorn later in zijn boek Gevangen in de tijd, werd versterkt door met name drie factoren: 'de uitdrukkelijk morele kwalificatie van de taakopdracht, het geografisch element van de taakuitvoering en de uiteindelijke vergeefsheid van alle inspanningen en offers' (2002e: 27). Vooral de wisselwerking tussen de eerste en de derde factor zag Van Doorn terug bij de militaire avonturen die zich na afloop van de Koude Oorlog ontwikkelden. Om te beginnen in Bosnië. 


\section{De fuik van Bosnië: militair pacifisme}

Aan de vooravond van de val van Srebrenica schreef Van Doorn in HP/De Tijd een beschouwing onder de kop 'In de Bosnische fuik'. Eén van zijn stellingen luidde: 'Men had aan het hele avontuur nooit moeten beginnen, maar de aangevallen Bosniërs van geld, goede raad en wapens moeten voorzien, zodat ze zichzelf hadden kunnen verweren. De VN heeft daar niets te zoeken' (Ten Cate 2007: 147). ${ }^{2}$

Van Doorn was van meet af aan tegen interventie in Joegoslavië geweest, wanneer die zou plaatsvinden onder regie van de Verenigde Naties. In de zomer van 1992, toen het internationale debat over Bosnië hoog oplaaide, vooral onder invloed van televisiebeelden die het bestaan van concentratiekampen suggereerden, kwam hij tot de conclusie, meer een verzuchting eigenlijk, dat alleen een 'grote nabuur', orde op zaken had kunnen stellen. Een dergelijke vorm van 'milde rekolonisatie' zou ook in andere delen van de wereld opportuun zijn, aldus Van Doorn. Want terzelfder tijd speelden zich ook elders, in de Kaukasus, in delen van Azië en Afrika, gewelddadige drama's af, vaak nog een stuk groter en bloediger dan op de Balkan. Met z'n allen maken die deel uit van een 'mondiale transformatie', effect van het uiteenvallen van imperia, langer en korter geleden, daarbij inbegrepen de echo's van de dekolonisatie. Maar bij ontstentenis van een grote nabuur of een historische vriend zag Van Doorn hoe dan ook geen militaire rol weggelegd voor de Verenigde Naties, ook niet in voormalig Joegoslavië (Van Doorn 1996 [1992]).

Toch onderstreepte hij korte tijd later de logica van een nieuw type soldaat die na de Koude Oorlog de ouderwets geworden figuur van de dienstplichtige moest gaan vervangen. In de herfst van 1992 was de beslissing om tot een beroepsleger over te gaan bijna beklonken en Van Doorn sloot zich daar volmondig bij aan. In feite had hij al veel eerder voorzien dat het 'massa-leger' op z'n retour was - begin jaren zeventig schreef hij er een artikel over dat klassiek zou worden binnen de militaire sociologie (Van Doorn 1975). Maar nu was het dan ook echt zover, na het verdwijnen van de noodzaak om met zoveel mogelijk mankracht de legers van het Warschaupact tegen te houden. In plaats daarvan 'zoekt men het meer en meer in vredesoperaties en crisisbeheersing en daarmee in een internationale taakvervulling'. Dat vergde weliswaar een nieuwe beroepsmotivatie en een besef van risico's, maar toch: 'De ideale militair van de toekomst, niet langer dienaar van de nationale staat, maar wereldburger in uniform, handelend op gezag van een supranationale autoriteit' (1992).

Dit beeld had z'n eigen aantrekkingskracht en historische logica, maar het bleef ver af staan van wat er intussen in Bosnië gebeurde. Daar bleken de blauwhelmen op gezag van de VN vrijwel machteloos om het 
vechten en moorden te stoppen en konden zij hooguit, als de strijdende partijen het toelieten, humanitaire hulp verlenen. Eind 1994 hekelde Van Doorn de 'linkse schrijftafelstrategen', die op interventie hadden aangedrongen en stelde hij tegelijkertijd het risicomijdende 'militair pacifisme' aan de kaak, dat effectief optreden in de weg stond (1994). Bij elkaar genomen klonk dat een beetje als 'the food is awful - and such small portions' ${ }^{3}$ Bovendien, voor- en tegenstanders van interventie waren zowel links als rechts in het politieke spectrum te vinden, ${ }^{4}$ en de belangrijke beslissingen over Bosnië werden door een brede meerderheid van de Tweede Kamer gesteund. Nee, vredesmissies als 'geloofsartikel van links', dat was overdreven.

Met wat hij 'militair pacifisme' noemde roerde Van Doorn echter wel een cruciale kwestie aan binnen het discours over militaire operaties, zoals dat zich in de jaren negentig ontvouwde. Hebben samenlevingen nog het incasseringsvermogen voor de dodelijke gevolgen van oorlogvoering? Durven politici in het Westen de krijgsmacht nog in te zetten voor levensgevaarlijke missies? Zijn militairen zelf het vechten niet verleerd? De Amerikaanse terugtocht uit Somalië, in oktober 1993, en het falen van de VN in Rwanda, in het voorjaar van 1994, golden als typische voorbeelden van hoe het sneuvelen van soldaten het draagvlak voor missies ondermijnt. Bosnië leek te bewijzen dat daarop werd geanticipeerd, op het snijvlak van politieke besluitvorming en militaire commandovoering, door de risico's op voorhand zoveel mogelijk uit te sluiten. Het staat allemaal in scherp contrast, zegt Van Doorn, met de oorlogen van vroeger, toen miljoenen sneuvelden 'zonder protest van de volken die deze offers jarenlang brachten' (1994).

$\mathrm{Al}$ met al is militair pacifisme een contradictio in terminis: 'Hoe kan een krijgsmacht ooit nog in actie komen indien er niemand mag sneuvelen? Het is als een brandweer die weigert te blussen omdat er dan water verloren gaat.' De vergelijking wringt, want de brandweer gaat juist uiterst risicobewust te werk, is kwistig met water maar helemaal niet met personeel. Maar het punt dat Van Doorn wil maken is duidelijk, al drijft hij het op de spits. Want één gedode Nederlandse soldaat, voorspelt hij tot slot, zal aanleiding zijn, helemaal als de televisie erbij is 'om voor altijd afscheid te nemen van hooggestemde vredesmissies in streken waar wij niets te zoeken hebben' (1994). Ook dat was overdreven. ${ }^{5}$

Dat Bosnië voor UNPROFOR een fuik was geworden, zoals Van Doorn medio 1995 schreef, was echter allerminst overdreven. De gijzeling van blauwhelmen door de Bosnische Serviërs maakte van deze missie eens te meer 'een beschamende vertoning': 'Een operatie als deze, waarbij niet alleen mensenlevens maar ook de reputatie van de volkerenorganisatie op het spel staat, had nooit mogen worden begonnen, zonder dat men wist hoe er weer uit te komen' (Ten Cate 2007: 147). Het ergste moest toen 
nog komen, met de overrompeling van Srebrenica en de massamoord op vele duizenden Bosnische mannen en jongens. Dat drama, schreef Van Doorn begin augustus, onderstreepte het ongelijk van al degenen die vanaf 1992 vurig voor interventie hadden gepleit (Ten Cate 2007: 149). Maar aan het eind van die maand kwam het toch nog, door toedoen van de NAVO, tot fors militair optreden tegen de Serviërs, vanuit de lucht en op de grond - dat laatste overigens vooral ook door het oprukken van Kroatische troepen. Was dit niet het type robuuste interventie dat de pleitbezorgers altijd voor ogen hadden gehad? Was het werkelijk ondenkbaar geweest om dat veel eerder te doen? Of was dat hoe dan ook een illusie, omdat het belang van Bosnië in Washington, Londen en Parijs nu eenmaal niet zwaar genoeg woog? ${ }^{6}$

Zo kan het gelijk en ongelijk aan beide zijden van het interventiedebat van kanttekeningen worden voorzien. Maar dat de VN-missie zoals die zich in werkelijkheid een aantal jaren voortsleepte een dramatisch fiasco was, daarover kon geen verschil van mening bestaan. De vraag hoe dat precies had kunnen gebeuren en wie daarvoor per slot van rekening verantwoordelijk was, hield zowel de Verenigde Naties als Nederland nog lang bezig. Voor het rapport dat secretaris-generaal Kofi Annan eind 1999 publiceerde had Van Doorn veel lof (1999). De VN trok daarin vooral zelf het boetekleed aan en nam de volle politieke verantwoordelijkheid voor wat misging. In de kern van de zaak was dat de discrepantie tussen verwachtingen en middelen: 'In Bosnië-Herzegovina (werd) een vredesmissie uitgevoerd terwijl er een oorlogstoestand heerste.' Dat was dan ook de grote les die de VN trok: 'aan vredestroepen mag nooit meer de opdracht worden verstrekt tegen een militaire macht op te treden.'

Over de rol van Dutchbat was het VN-rapport mild. In de gegeven omstandigheden, zo was de strekking, hadden de Nederlandse militairen weinig anders kunnen doen. De aanval van de Serven had alleen met luchtsteun gepareerd kunnen worden - en die bleef uit. Een menselijk schild om de burgers heen had wellicht tijd kunnen winnen, maar het had ook een Servische beschieting kunnen uitlokken. Bij elkaar genomen een 'tamelijk vriendelijk eindoordeel', constateert Van Doorn, ongetwijfeld tot tevredenheid van de Nederlandse politici en militairen, die altijd al hadden volgehouden dat Dutchbat geen blaam trof. Maar Van Doorn verwachtte niet dat nu 'het boek Srebrenica' dicht kon. Niet zozeer omdat het NIOD nog moest rapporteren en ook niet omdat er steeds maar weer nieuwe onthullingen over incidenten waren. Nee, de hoofdzaak waarom Srebrenica niet voorbij zou gaan, lag op een ander niveau: 'Wat onaantastbaar pijnlijk in onze herinnering beklijft, zijn beelden die naar de kern van onze schaamte verwijzen.'

Van Doorn (1999) noemt hier in het bijzonder de beelden van overste Karremans en generaal Mladic, de eerste niet opgewassen tegen de 
tweede. Maar dat gold, zegt hij, evenzeer voor 'onze soldaten', al valt hen dat niet te verwijten: 'Kinderen van hun tijd, kinderen van een lange periode van vrede en burgers in uniform van een vriendelijk land.' Dat zij werden uitgezonden, 'met te weinig mensen en te lichte wapens', dat moet de politieke leiders worden aangerekend die tegen het advies van de militaire leiders in 'het avontuur doorzetten'.

Het is in Bosnië gegaan zoals het een halve eeuw geleden in Nederlands-Indië ging. De troepen die werden uitgezonden - ik was erbij - vervulden een kolossale humanitaire missie. Ze waren niet bestemd voor het voeren van een oorlog, maar voor het vestigen van orde en rust. Hun opmars kreeg de naam van 'politionele acties', want de schijn moest tot elke prijs worden gehandhaafd. Hun inspanningen waren vergeefs. Het Nederlandse leger was te licht bewapend en bovendien niet groot genoeg om de Indonesische Republiek op de knieën te dwingen. In de guerrillaoorlog die ontstond, waren de Nederlandse dienstplichtigen geen partij voor de taaie weerstand van de Indonesiërs. Een mission impossible, zoals in Srebrenica.

De parallel stipt de twee factoren aan die, zo zagen we eerder, volgens Van Doorn sterk hun stempel drukten op de ervaring van de Indië-veteranen: een moreel gekwalificeerde missie die vergeefs blijkt. Daarbij zal tussen en binnen beide categorieën veteranen zeker gelden dat er ook allerlei verschillen zijn in de terugblik op de missie en de verwerking ervan in de latere levensloop. Niet voor iedereen zal de notie van vergeefsheid onverkort en ondubbelzinnig het laatste woord hebben. Erkenning vanuit de samenleving speelt in dat proces dan weer een belangrijke rol en vooral natuurlijk de toedeling van verantwoordelijkheid. Per saldo kwam die, zo lijkt het, bij Bosnië een stuk sneller ter tafel dan bij Indië, maar het duurde, vond Van Doorn, ook in dit geval nog te lang. In een beschouwing over het rapport van het NIOD, dat hij kraakte, beoordeelde Van Doorn het aftreden van het kabinet-Kok, zeven jaar na dato, als 'merkwaardig' en 'onzuiver'. Het had na de val van Srebrenica meteen moeten gebeuren: 'Openlijk verantwoording nemen voor ernstig politiek blunderen.' Al met al: 'Het drama is geëindigd in politieke paniek. Er werd niets groots verricht' (Van Doorn 2002b).

\section{Commentaar}

Betekende het Bosnische debacle wat Van Doorn betreft nu ook de definitieve afrekening met de wereldburger in uniform als de 'ideale soldaat van de toekomst'? In hun inleiding bij Van Doorns postuum gepubliceer- 
de essaybundel Nederlandse democratie. Historische en sociologische waarnemingen (2009) maken Jos de Beus en Piet de Rooy gewag van diens 'groeiende distantie ten opzichte van de idealistische visie van Janowitz, zijn Amerikaanse collega in de militaire sociologie. Van Doorn raakte ervan overtuigd dat humanitaire interventie onder de vlag van de Verenigde Naties ofwel theorie was, omdat zij in strijd is met het nationale eigenbelang van de deelnemende staten, ofwel een terugkeer van kolonisatie, praktisch gesproken, met alle innerlijke tegenstellingen van een westers imperialisme' (Van Doorn 2009: 22-23). Het begin van die distantie dateren De Beus en De Rooy al bij de publicatie van Ontsporing van geweld, in 1970. Dat was niet alleen een reactie op de actualiteit, zeggen ze, maar paste in de ontwikkeling van Van Doorns opvattingen in dit verband.

$\mathrm{Nu}$ was het Nederlands optreden tegen Indonesië misschien wel als een humanitaire missie te kwalificeren, maar het vond geenszins plaats onder VN-vlag. Integendeel, het was een nationale Alleingang, zoals alle koloniale contraguerilla. Bovendien, vlak voor Ontsporing van geweld, had Van Doorn nog een militair-sociologisch paper geschreven waarin de legitimiteit en effectiviteit van internationale militaire operaties onder gezag van de VN werd geanalyseerd. Daarin werden allerlei knelpunten en dilemma's aangeroerd, maar toch onmiskenbaar op een positief-constructieve manier. Het paper eindigt met een haast programmatische typering van de militair van de toekomst en zijn nieuwe professionele bagage: '(...) the constabulary philosophy will be the "core" of the future professional pattern. Old soldiers never die, and neither does their institution, but it must be reconstructed in accordance with the future international order' (Van Doorn en Mans 1967: 376).

Kortom, de datering van Van Doorns twijfel over VN-interventies rond 1970 lijkt wat vroeg. En zelfs begin jaren negentig, zo zagen we, kwam het idee van de wereldburger in uniform nog wel eens bij hem op. Dat neemt niet weg, en daarin hebben De Beus en De Rooy helemaal gelijk, dat de gemankeerde militaire avonturen van de jaren negentig, in Bosnië en elders, tot onmiskenbaar sceptische of regelrecht pessimistische beschouwingen leidden. Dat zou er bij het wapengekletter in het begin van de eenentwintigste eeuw niet beter op worden, zoals we zo dadelijk zullen zien, al zou Van Doorn juist toen de VN soms enigszins gaan missen.

Wat was intussen nu precies het standpunt van collega Morris Janowitz, de Amerikaans peetvader van de militaire sociologie? Dat draaide om een formule, waarin de 'constabulary philosophy' centraal stond (Janowitz 1960: 418). 
The use of force in international relations has been so altered that it seems appropriate to speak of constabulary forces, rather than of military forces. The constabulary concept provides a continuity with past military experiences, but it also offers a basis for the radical adaptation of the profession. The military establishment becomes a constabulary force when it is continuously prepared to act, committed to the minimum use of force and seeks viable international relations, rather than victory, because it has incorporated a protective military posture. The constabulary outlook is grounded in, and extends, pragmatic doctrine.

Janowitz gaf toe dat hij een zwak had voor 'the symbolism of international policing and peacekeeping', maar zijn 'constabulary force' is nooit een recept geweest voor al te idealistisch opgevatte interventies van blauwhelmen. Het wapenarsenaal ervan, voor zover in Amerikaanse handen, strekte zich uit tot en met de afschrikwekkende atoombom toe. Maar de uitdrukking 'minimum use of force' vormt toch de crux van deze formule. Vermoedelijk ging het hem er vooral ook om juist de militaire macht van de Verenigde Staten te temmen en in te bedden en aldus te legitimeren.

Janowitz overleed in 1988 en dus kunnen we slechts gissen naar of en hoe hij zijn 'constabulary force' had willen herijken in het licht van de gemankeerde interventies van de jaren negentig. En of hij het eens zou zijn geweest met de harde kritiek van zijn collega Van Doorn op hoe uitgerekend de VS, vanaf 2001, ten strijde trokken, eerst in Afghanistan, toen in Irak. In de kern van de zaak wel, denk ik. Het past in Janowitz' kritische positie, die door van Doorn later nog eens werd onderstreept: op afstand van het politieke en militaire establishment (Van Doorn 2007d).

\section{De fuik van Afghanistan: oorlog tegen het terrorisme}

'Werkelijk, indien er een negatieve Nobelprijs voor de Vrede bestond, een prijs voor onovertroffen mondiale stompzinnigheid - president Bush zou al jarenlang een goede kanshebber zijn.' Dat schreef Van Doorn in de herfst van 2006, naar aanleiding van het verschijnen van een bundel beschouwingen, die vanaf om en nabij de eeuwwisseling waren gepubliceerd in het Trouw-katern 'Letter en geest'. Van Doorn hekelt de 'zeer hoge toon' die in veel van de stukken wordt aangeslagen, alsmede de 'bloeddorstige strekking' ervan. Hij gruwt van de oproep tot 'onbekrompen geweld' en tot 'meedogenloosheid', het idioom van Amerikaanse neoconservatieven dat na 9/11 ook in Nederland her en der werd gebezigd. Hij hoont de averechtse effecten van de oorlog tegen het terrorisme 
en van de grand strategy waarmee George W. Bush de 'As van het Kwaad' te lijf gaat (2006f).

Terugkijkend billijkte Van Doorn in een eerder stuk in datzelfde najaar dat de aanslag op de Twin Towers niet ongestraft had kunnen blijven en memoreerde hij hoe Amerika bij het aanpakken van Al-Qaeda en van de Taliban, aanvankelijk wereldwijde politieke steun ondervond. Maar in plaats van dat karwei 'rigoureus' en 'effectief' te klaren, werd 'militair risico' gemeden en werd het vuile werk op de grond uitbesteed aan 'Afghaanse onderaannemers'. Met als gevolg dat Osama bin Laden had kunnen ontkomen en dat de Taliban op de weg terug waren. Maar een nog 'veel ernstiger fout', aldus Van Doorn, werd gemaakt door de 'overbodige oorlog tegen Irak en de demonisering van Iran'. Gevoegd bij de vrije hand die Rusland en Israël kregen, om respectievelijk Tsjetsjeens en Palestijns verzet als 'islamitisch terrorisme' de kop in te drukken, konden de machtspolitieke bedoelingen van Bush aldus ontmaskerd worden en in historisch perspectief gezet: 'Amerika is bezig de moslimwereld opnieuw te koloniseren. Opnieuw, want dat is eeuwenlang door Europese mogendheden gedaan. Engeland voorop, al heeft ook Nederland, als kolonisator van het grootste moslimland, Indonesië, een flinke partij meegeblazen' (2006d).

Vijf jaar eerder, toen de Amerikaanse aanval op Afghanistan net was geopend, mijmerde Van Doorn over de 'wonderlijke terugkeer van de koloniale idee'. Want de bemoeienis met 'mislukte staten' en de pogingen daar democratische instellingen en een functionerend gezag te vestigen, lijken een echo van vroegere vormen van koloniaal bestuur. Of het nu wordt ingegeven door harde veiligheidsbelangen, zoals in Afghanistan, of door bekommernis om mensenrechten, zoals soms in Afrika, het blijft 'koloniale' bemoeizucht. De aanhalingstekens zijn van Van Doorn zelf - want uiteraard wordt de harde term 'koloniaal' vermeden. Toch komt het daar zijns inziens vaak op neer: 'De bemoeienis met "mislukte staten” (krijgt) onwillekeurig het karakter van "pacificatie” en politionele interventie. Precies zoals het historische kolonialisme op het programma had staan, gelegitimeerd door een combinatie van politieke ambities, economische belangen en een gevoel zich met een mission civilicatrice te moeten belasten' (2001c).

Zelf had Van Doorn begin jaren negentig geopperd dat een 'milde vorm van rekolonisatie' in allerlei gebieden en landen orde en ontwikkeling zou kunnen bewerkstelligen (zie de vorige paragraaf). Dat ging destijds de kracht van de Verenigde Naties te boven, zoals onder meer in Bosnië bleek, maar sterke (nabuur)landen zouden een dergelijke rol misschien wel hebben kunnen spelen. De manier waarop het allersterkste land na 9/11 de wereld naar zijn hand wilde zetten, kon echter in geen enkel opzicht voor 'milde rekolonisatie' doorgaan. Van Doorn wilde in 
zijn algemeenheid nog wel voordelen ontwaren aan een Pax Americana (2002a). Maar de vigerende ontplooiing van militaire macht in Afghanistan en Irak, eerst en vooral via grootschalig 'technisch geweld' (2001b), 142 gekoppeld aan de arrogante politieke retoriek van de overmoed en het 'exceptionalisme' (2002a), dat alles kon alleen maar destructieve tegenkrachten oproepen.

De grote fout die Amerika blijft maken, is de onderschatting van de historische en politiek-psychologische factoren die ten grondslag liggen aan het huidige terrorisme in de islamitische wereld. Terecht of ten onrechte - dat maakt politiek geen verschil - wortelt de weerzin van de moslimlanden tegen het Westen in de koloniale bemoeienis van Europa in het verleden en in de imperialistische rol van Amerika in het heden, het meest uitdagend belichaamd in de agressieve politiek van Israël, Amerika's '51ste staat'.

Van Doorn mocht graag de rol van Israël aan de kaak stellen als vermaledijde voorpost van het Amerikaanse imperium - 'een nieuwe kolonie die tot op de dag van vandaag als een doorn in het islamitische lichaam steekt' (2001a) - en ook als loepzuiver voorbeeld van de manier waarop militaire bezetting tot ontsporing van geweld leidt (2002c). Maar de andere bondgenoten maken het er niet beter op en bevestigen alleen maar de wijze waarop Van Doorn Amerika's 'oorlog tegen het terrorisme' las. Dat uitgerekend de NAVO de International Security Assistance Force (ISAF) gaat leiden en bemannen wordt als 'vreemd' beoordeeld. Bij al zijn gebreken, aldus Van Doorn, zou het toch logischer zijn geweest als de Verenigde Naties de leiding zouden nemen in de opbouw van Afghanistan, want als organisatie zorgt die bij uitstek voor 'internationaal draagvlak'. Gezien zijn kritiek op de VN ten tijde van Bosnië kon Van Doorns voorkeur opmerkelijk lijken. Daar komt nog bij dat ISAF wel degelijk de zegen van de Veiligheidsraad had. Maar het ging hem, zoals steeds opnieuw, om dat ene centrale punt, ook en bij uitstek belichaamd door de NAVO: 'een Amerikaans-Europees consortium dat op oud-koloniale wijze, naar eigen goeddunken, "rust en orde" in vreemde landen wenst te verspreiden. Dat gaat tegen ons werken.' Waaraan werd toegevoegd, bij wijze van goed-sociologische kanttekening, dat de NAVO een schoolvoorbeeld is van een organisatie die, wanneer het oorspronkelijke doel vervalt, op zoek gaat naar een nieuwe reden van bestaan (2006c).

Als lid van de NAVO, en ook wel als vriend van de Verenigde Staten, ging Nederland meedoen in Afghanistan. Vanaf het allereerste begin, in het najaar van 2001, had Van Doorn er geen goed woord voor over. Hij bespotte de omzichtige en indirecte manier waarop Operation Enduring Freedom met vliegtuigen en schepen werd gesteund, al paste 
de ongemakkelijke houding die premier Kok uitstraalde bij 'de Nederlandse traditie, die beter uit de voeten kan met een Vredespaleis en een Joegoslavië-Tribunaal dan met grootscheepse krijgshaftige avonturen'. Maar de motieven om meer symbolisch dan daadwerkelijk mee te doen in deze oorlog werden door Van Doorn gewantrouwd. Buitenlandspolitieke berekening was er natuurlijk niet vreemd aan, zomin als de drang van bedreigde krijgsmachtonderdelen om zichzelf op de kaart te zetten. Maar woog wellicht niet het zwaarst de kans om makkelijk te 'scoren', doordat het sturen van een 'paar vliegtuigen en marineschepen naar een oorlogsgebied' de aandacht afleidde van binnenlands-politieke onmacht? 'De files volgend jaar met vijf procent terugdringen: een heidens karwei. De beschaving en de democratie verdedigen en bondgenoot Amerika bijstaan: een fluitje van een cent' (2001d).

Een dergelijke kwalificatie was niet echt van toepassing op het besluit, ruim vier jaar later, om Nederlandse militairen, als onderdeel van ISAF uit te zenden naar Uruzgan. Wat ook de precieze drijfveren en doelstellingen waren, een fluitje van een cent was het niet. Gezien de manier waarop Van Doorn in de tussenliggende jaren de oorlog tegen het terrorisme was gaan lezen en de machten en krachten die eraan ten grondslag lagen interpreteerde, kwam het echter niet als een verrassing dat hij ook in deze nieuwe missie geen enkel vertrouwen had. Nederland verbond zich aan een westers project dat in een vlaag van 'imperiaal optimisme' was gestart - van Afghanistan een 'moderne' natie maken - maar dat inmiddels een 'bijzonder moeizame aangelegenheid' was geworden. Nog los van het 'lopende gestuntel' en het 'kissebissen' op het Binnenhof, inbegrepen een discussie die ten onrechte van 'veiligheidsrisico's' de centrale kwestie maakt - 'de hele operatie is een volstrekte dwaasheid omdat de ambities die men koestert op geen enkele manier kunnen worden waargemaakt' (Van Doorn 2005).

Waar is ons geheugen als koloniale mogendheid gebleven? In Indië hebben we meer dan een halve eeuw getracht een met Uruzgan vergelijkbaar gebied bestuurlijk en economisch op te bouwen: Atjeh, even onherbergzaam, met een even weerbarstige en orthodoxe islamitische bevolking en eveneens (evenmin? JvdM) levenskrachtig politiek centrum. We hadden letterlijk alles ter beschikking: een voortreffelijk leger, een ervaren bestuursapparaat, diepgaande kennis van land, taal en volk, een zee van tijd en een hardnekkigheid, een betere zaak waardig. Maar we zijn nooit een stap gevorderd. In Uruzgan hebben we niets vergelijkbaars: geen overmacht, geen inzicht, geen kennis van zaken. Een paar honderd jongens gaan daar een paar jaar rondsjouwen, bezig met wat armoedige bouwprojecten en met de training van een hand- 
vol onwillige en onbetrouwbare inheemse militairen en politiemensen. Dan mogen ze naar huis, om een herinneringsspeld in ontvangst te nemen. Wie bedenkt zoiets?

Op oudejaarsdag 2005 gepubliceerd, toen het Haagse geharrewar nog niet eens tot een definitief besluit had geleid, was het een even karakteristiek als hermetisch oordeel. Dit keer niet met de allerlaatste NederlandsIndonesische confrontatie als referentiepunt, maar met een eerdere, veel langere militaire inspanning, hoogtij van onverbiddelijk kolonialisme, als analogie. Dat in Atjeh nooit enige voortgang werd gemaakt, for better or for worse, valt moeilijk vol te houden. En de wijze waarop Van Doorn op voorhand de missie in Uruzgan afserveert, is karikaturaal. Toch is de zeggingskracht van de vergelijking groot: de opsomming van wat er vroeger in Atjeh allemaal voorhanden was aan militaire, bestuurlijke, wetenschappelijke en culturele knowhow, geschraagd door (politiek) geduld en (professionele) toewijding, kleineert op retorisch effectieve wijze de voorgenomen inspanningen in Uruzgan. En onderstreept de overtuiging dat het tegenwoordig ontbreekt aan werkelijk inzicht in de enormiteit van 'militaire pacificatie' en 'civiele wederopbouw', als dubbele opgave in een land als Afghanistan.

In de maanden die volgden gebeurde er weinig dat Van Doorns overtuiging aan het wankelen kon brengen. Integendeel, het was wat hem betreft allemaal 'verwarring en verwatenheid' die de klok sloegen, verwarring over wat het eigenlijke doel van de missie was, verwatenheid over wat er bereikt kon worden. 'Het gezag van de Afghaanse regering zal worden hersteld. O sancta simplicitas!' (2006a). Dat nog voordat de militairen goed en wel ter plaatse waren, de beoogde 'opbouwmissie' hand in hand bleek te moeten gaan met een onvermoede 'gevechtsmissie', onderstreepte vooral de verwarring, zo leek het. Want kon voor een loutere militaire opbouwmissie, aldus Van Doorn in een zeldzaam mild moment, 'de kans op succes vrij groot (lijken)', dan kwamen met een 'sterk verslechterde veiligheidstoestand', de kaarten toch heel anders te liggen. Natuurlijk, terugtrekken kon niet meer, 'het bloedige spook van Srebrenica zou onmiddellijk herrijzen.' Niettemin, de wending die de missie ineens ging nemen, mocht vooral de minister van Defensie zich aantrekken: 'Als er straks, door Kamps misrekening, Nederlandse militairen sneuvelen, zou het hem sieren als hij, als eerst verantwoordelijke, aftrad. Hij heeft Nederland de fuik binnengelokt' (2006b).

Als er dan toch gevochten moest worden, kon de manier waarop dat gebeurde ook op Van Doorns kritisch commentaar rekenen - net zoals ten tijde van Bosnië zijn categorische afwijzing van interventie soms werd afgewisseld met kritiek op het hoe ervan. Gedurende de eerste periode van de missie, vanaf de zomer van 2006 tot het voorjaar van 
2007, liet Van Doorn zich meerdere malen sceptisch uit over de manier waarop de Nederlandse militairen in Uruzgan opereerden. Hij vergeleek kamp Holland met Fort Bastiani uit De Tartaarse woestijn van Dino Buzzati, een onneembare veste in niemandsland. Maar de oorlog kan alleen worden gewonnen door de veiligheid te verlaten en er op uit te trekken 'opereren in kleine eenheden en beschikken over inlichtingen.' Zo deed het KNIL het ook: zie het Voorschrift voor de uitoefening van de Politiek Politionele taak van het Leger (V.P.T.L) dat in Indië leidraad was, eerst in Atjeh maar ook tussen 1945 en 1949 tijdens het eindspel (2006e).

Latere, vergelijkbare opmerkingen, dit keer voortbordurend op de kritiek die bondgenoten kennelijk uitoefenden op de al te "behoedzame Dutch approach' (2007b), leidden tot een reactie van generaal-majoor b.d. J. Schaberg (2007). Het meningsverschil zat hem echter niet zozeer in de taxatie van de 'vastberadenheid' waarmee in Uruzgan te werk werd gegaan. Ze vonden allebei dat die tekortschoot, overigens meer als verwijt aan de politieke dan aan de militaire leiding. Maar terwijl Schaberg overtuigd was van de noodzaak van de missie en in het algemeen gesproken ook wel degelijk vooruitgang zag in Afghanistan, bleef het voor Van Doorn hoe dan ook een 'uitzichtloze onderneming' (2007b) dan wel een 'onmogelijk ontwikkelingsproces' (2007a). Want ook de opbouwkant werd in laatste instantie gewogen en te licht bevonden. Dat tientallen landen 'druk zijn' met 'reconstructieteams' werkt al niet. Bovendien, succesvolle ontwikkeling vergt 'meerdere generaties'. Maar precies die tijdsduur maakt er een koloniaal project van en dan is de historische slotsom onverbiddelijk. 'Het is illusiepolitiek: doe wat je wilt, het antwoord zal onwelwillend zijn en blijven. Noem het stank voor dank, maar leer uit de koloniale geschiedenis dat dit de normale reactie is' (2007a).

Die laatste notie vormt zonder twijfel de rode draad van alle commentaar dat Van Doorn vanaf najaar 2001 en vervolgens vanaf eind 2005 wijdde aan respectievelijk de Amerikaanse oorlog tegen het terrorisme en de Nederlandse inzet in Uruzgan. Zijn laatste essay in dit verband 'In de fuik van een gewelddadig avontuur met neokoloniale ambities' pelt nog eens alle lagen en implicaties van die notie af: van internationale machtspolitiek, via mondiale sociale en religieuze tegenstellingen, tot de dynamiek van militaire bezettingen. En natuurlijk geïllustreerd, zoals aan het begin van dit hoofdstuk al ter sprake kwam, met dat ene conflict in die ene periode, toen 'ons hetzelfde overkwam, zij het in een honderdvoudige uitvergroting'. Nog één keer dan hoe het destijds afliep tussen kolonisator en opstandeling (Van Doorn 2008).

Het resultaat was een jarenlange, uitzichtloze geschiedenis van afwisselend praten en slaan. Evenmin als in Uruzgan waren we in staat meer druk op de ketel te zetten en evenmin bereid de tegen- 
partij voldoende tegemoet te komen. Zo leek het conflict onoplosbaar. Pas toen een laatste militaire inspanning onvoldoende soelaas leek te bieden, werd tot een afrondend diplomatiek overleg besloten, in feite eindigend in de capitulatie.

Het gaat natuurlijk niet letterlijk op en het woord 'capitulatie' willen we niet horen, maar begin 2010, twee jaar nadat Van Doorn dit schreef, klinkt de parallel tussen toen en nu, tussen Indië en Uruzgan, haast nog treffender. Niet alleen omdat Nederland vertrekt uit dat gebied, maar ook omdat Obama's Amerika zijn afscheid heeft aangekondigd. Inderdaad, na nog een extra militaire inspanning, maar op voorhand wordt erkend dat ook die de definitieve overwinning niet kan brengen. Dus wordt meer dan ooit een diplomatiek akkoord gezocht. Had Van Doorn eigenlijk niet een groot gelijk aan zijn zijde? Had hij misschien gewoon altijd gelijk met zijn fundamentele kritiek op de vergeefsheid van militaire interventies?

\section{Slotbeschouwing}

Op een aantal observaties en oordelen van Van Doorn over Afghanistan valt best het één en ander af te dingen. Met zijn brede blik zag hij ook wel ontwikkelingen en prestaties over het hoofd, zowel militaire als civiele, die het beeld complexer maken en minder zwartgallig. De microwereld waarin civiel-militaire samenwerking gestalte krijgt, ingekaderd in 3D-achtige beleidsvisies (defense, diplomacy and development) en met opnieuw doordachte counter-insurgency op de achtergrond, staat niet alleen model voor goede bedoelingen en mislukte projecten. De Dutch approach was niet slechts oervoorzichtig, maar had gaandeweg ook het initiatief. En de zich van binnenuit manifesterende Afghaanse civil society is niet louter speelbal van corrupt bestuur, tribale identificaties en terroristische tegenstand, maar verwerft een eigen dynamiek en draagvlak.

Ook in de literatuur over dat alles, wetenschappelijk gefundeerd of meer journalistiek getint, wordt veel meer aangesneden, van dichterbij en indringender gekeken. Van Doorn baseerde zich op een algemener soort informatie en duidde die met zijn eruditie en vanuit zijn wereldbeeld. Hij bedreef wel degelijk historiserende sociologie, zoals eertijds samen met W.J. Hendrix over het Nederlands-Indonesisch conflict. Maar het boek dat zij samen schreven had een stevig empirisch fundament en een hecht analytisch raamwerk, en kon aldus overtuigend en gedetailleerd microgebeurtenissen met macroprocessen in verband brengen. Op die manier kon Van Doorn dat natuurlijk niet doen in zijn columns en essays. Die hadden een heel andere insteek en behoren tot een ander genre. Voor de kritische appreciatie ervan maakt dat uit, de eigen meri- 
tes en beperkingen ervan mogen niet uit het oog worden verloren. Maar niet voor niets stond in dit hoofdstuk de studie van Van Doorn en Hendrix voorop. Daarmee in het achterhoofd - en natuurlijk ook nog wel met andere publicaties - winnen Van Doorns krantenstukken sterk aan reikwijdte en belang.

Zijn stukken over militaire 'avonturen' - dat woord bleef terugkomen - verschenen vanaf begin jaren negentig als bijdragen aan het publieke debat. Ze waren opiniërend en polemiserend en gebruikten daarbij horende stijlmiddelen zoals overdrijving, ironie en sarcasme. Maar ze waren ook en vooral analyserend, de lange essay-achtige logischerwijs het meest, maar zelfs in de kortste columns, zoals in zijn rubriek 'Kortom' in HP/De Tijd, bleef het intellectuele raamwerk achter de mening zichtbaar. De beschouwingen versterkten elkaar en droegen stuk voor stuk bij aan de herkenbaarheid van Van Doorns visie, zijn wereldbeeld in het algemeen en zijn kijk op de inzet van legers in het bijzonder.

De historische analogie was in dit verband onmiskenbaar zijn favoriete conceptuele gereedschap, met zowel theoretische als morele implicaties. Vroeg of laat dook de koloniale metafoor op en die maakte van de militaire avonturen haast per definitie gedoemde ondernemingen. Van Doorn legde de paradox ervan scherp bloot: om werkelijk resultaat te boeken moeten ze lang worden volgehouden en naarmate de tijd verstrijkt roepen ze meer verzet op - niet alleen ter plekke, maar ook aan het thuisfront. Want zo 'stoïcijns' als vroeger wordt het sneuvelen van soldaten niet meer geaccepteerd en terwijl het publiek meer 'kortaangebonden' is geworden, hebben de autoriteiten aan 'prestige' verloren (2008). Een dergelijke verkleining van de speelruimte om interventies te rekken lijkt in zekere zin winst, maar wordt door Van Doorn niet ondubbelzinnig op die manier geboekt. Hij spot met de obsessie van politieke en militaire leiders met de 'kans op dodelijk slachtoffers'. Krantenkoppen na het sneuvelen van de eerste Nederlandse militair in Uruzgan 'Eerste dode bedreigt missie niet' - beoordeelde hij als 'bijna belachelijk' (2007c).

Het punt werd ook bij Bosnië gemaakt, zo zagen we, maar wordt bij Afghanistan niet verder uitgewerkt. Daarmee blijft het een enigszins stereotype variant op de zogeheten slachtofferhypothese die in de literatuur inmiddels van allerlei nuances is voorzien die worden getoetst en betwist. Bij Van Doorn staat in zijn krantenstukken de berusting van vroegere generaties in dit verband nogal schematisch tegenover de brutaliteit van het huidige publiek - en dat doet aan geen van beide helemaal recht. In Gevangen in de tijd (2002d) wordt dan wel weer op een mooie manier uitgewerkt hoe zijn eigen generatie van Indië-veteranen, in meer algemene zin mee emancipeerde met en door de toenemende assertiviteit binnen de samenleving. 
Dat de stemmingen aan het thuisfront niet erg geschakeerd worden neergezet, soms louter in zwart-wit, komt waarschijnlijk ook omdat in de analyses van Van Doorn het zwaartepunt bij de mislukking van militaire avonturen elders ligt. Ontwikkelingen in de omgang met soldaten en legers spelen een rol - net als nationale eigenaardigheden - maar zijn op zich niet doorslaggevend. Het is veeleer de aanwending van militaire middelen als zodanig, als onderdeel van imperiale machtspolitiek en als krachtmeting met lokaal gewortelde tegenstanders en hun uitwaaierende netwerken en identiteiten, die tot patstellingen en nederlagen leidt. Van Doorn spreekt van 'sociologische wetmatigheden waaraan mensen - goedwillend of kwaadwillig - weinig kunnen veranderen' (2003b). Dat slaat op de fuik waar 'grote wereldrijken' in lopen, totalitair of democratisch, met hun mateloze ambitie en grenzeloze heerszucht. De koloniale paradox is het sluitstuk van die fuik, ook een sociologische wetmatigheid in feite. Van Doorn toont zich met regelmaat een ware structuralist die waarneemt hoe 'de geschiedenis zich herhaalt' (2003b).

Halverwege 1999, de oorlog om Kosovo was amper afgelopen, maakte Van Doorn op hem typerende wijze een vergelijking met honderd jaar eerder. Toen probeerde Nederland orde te stichten in Atjeh, een beschavingsmissie, waarvan de politieke en morele grondslag sprekend leek op de humanitaire interventie in Kosovo. Het daar vervolgens door de NAVO geïnstalleerde bestuur, 'heeft alles van een verlicht koloniaal initiatief (2009 [1999]: 369). Maar er was nog een treffende overeenkomst tussen toen en nu, aldus Van Doorn: de wens om geweld zo goed als mogelijk met 'chirurgische precisie' aan te wenden. Burgers moeten worden ontzien en verliezen onder de eigen soldaten worden beperkt. Net als aan het eind van de twintigste eeuw sprak daar destijds de verwachting uit die mensen koesterden (idem: 370).

Ze achtten de oorlog soms onvermijdelijk, zoals ook wij dat vinden, maar ze probeerden het geweld zoveel mogelijk te beheersen en te reguleren. Naarmate de beschaving voortschreed, zou volgens de burgerlijke overtuiging oorlog meer en meer ontoelaatbaar worden; naarmate het socialisme zijn invloed versterkte, zou oorlog zelfs volstrekt onmogelijk worden.

De twintigste eeuw zou een bittere en ongekende desillusie worden, de 'eeuw van het grote sterven'. Niettemin of misschien juist daardoor, lijken ten langen leste de grote confrontaties uitgewoed, in ieder geval in Europa. Van Doorn signaleert een hernieuwd streven naar het reguleren en beheersen van geweld. Weliswaar '(zijn) vredesoperaties maar matig effectief, maar dat ze keer op keer worden gepland, laat iets zien van onze diepe afkeer van ongeregeld geweld' (idem: 370 ). Dat het internatio- 
nale strafrecht zijn vleugels uitslaat, past in dat beeld en wordt door Van Doorn 'verheugend' genoemd. In een later stuk zou hij er ook op wijzen hoe het internationale recht, samen met de werking van de media, een 'formidabele rem' is op 'grove geweldsuitoefening' (2003a). Dat ging over de oorlog in Irak, die in 1999 nog enkele jaren achter de horizon lag.

Niet dat Van Doorn aan het eind van de twintigste eeuw een al te rooskleurig beeld van een vreedzame wereld schilderde. Buiten het Westen was er immers nog volop sprake van allerlei soorten geweld: "vervolging en marteling van politieke gevangenen, staatsgrepen en volksopstanden, reguliere oorlogen, massamoorden en etnische zuiveringen'. Bemoeienis van buitenaf valt niet uit te sluiten, met name wanneer belangen in het geding komen die het lokale conflict te buiten gaan. In zo'n geval 'zal de wereldgemeenschap overwegen in te grijpen' (Van Doorn 2009 [1999]: 376).

In die gemeenschap fungeert Amerika als de mondiale sheriff, als zelfbewuste drager van the white man's burden, die vernuftige doctrine die in de negentiende eeuw de legitimatie vormde van de koloniale mogendheden - Nederland niet uitgezonderd - die de wereld zagen als een jungle waarin orde en rust moesten worden gevestigd.

Beperkte interventies, politiek geboden en militair haalbaar, wees Van Doorn niet af, dunkt mij. Het pacifisme, zo had hij samen met Hendrix al vastgesteld, is geen bruikbaar alternatief maar eerder een manier om de ogen helemaal te sluiten voor de werkelijkheid van het geweld (1983: 329). Maar wanneer de sheriff zelf amok gaat maken, staat de fuik van militaire avonturen wijd open en worden historische ervaringen en sociologische lessen genegeerd. Van Doorn onderwees ze zelf, met groot gezag, maar was uiteindelijk niet verbaasd dat ze in de wind werden geslagen. Refererend aan de militair-historicus Michael Howard, die nauwkeurig voorspelde hoe de Amerikaanse inval in Irak zou aflopen, merkte hij koeltjes op: 'Het werd weer eens bewezen: vooral in zaken van oorlog en vrede zijn wetenschappelijke inzichten zelden tegen politieke vooroordelen opgewassen' (2007d).

\section{Noten}

1. Ik heb er voor gekozen om vrij veel te citeren en zo nauwkeurig mogelijk te parafraseren. Niet alleen vanwege Van Doorns 'mooie, afstandelijke en analytische stijl' (Schijf 2008), maar ook omdat ik de taal, de toon, de woordkeus als een databestand zie. In een al te uitgeklede samenvatting of weergave van uitspraken, die voor een typisch wetenschappelijk artikel wel kan of misschien zelfs moet, zou teveel verloren gaan van de zeggingskracht. Niet alle stukken die Van Doorn 
geschreven heeft komen in dit hoofdstuk terug. De selectie is echter alleszins representatief.

2. Enkele columns citeer ik via Ten Cate (2007).

3. De grap wordt gemaakt door Woody Allen, aan het begin van Annie Hall (1977).

4. 'Vóór interventie waren met name: Voorhoeve, Van den Doel, Leurdijk, de gebroeders Tromp, Wecke, Oostlander, Faber, Van Eekelen, Huyser, De Vogel, Bleich, Von der Dunk en Hofland. Tegen: de meeste militairen, Beunders, Brands, Van Doorn, Koch, Hilterman, Michielsen, Scheffer en J. Marijnissen, voorzitter van de Socialistische Partij' (NIOD 2002: 694).

5. Dit gedeelte is gebaseerd op een kritische analyse van Van Doorns column, die ik eerder schreef en die als ingezonden stuk in HP/De Tijd heeft gestaan (januari 1995). In dat stuk heb ik ook op het verschil gewezen met wat Van Doorn twee jaar eerder schreef over de 'ideale militair van de toekomst'.

6. Eén van de meest eloquente en naar mijn smaak meest overtuigende voorstanders van interventie was Bart Tromp (1996). Ook bij Uruzgan gunde hij de Nederlandse deelname, bij alle kritiek die er mogelijk was, het 'voordeel van de twijfel' (Het Parool, 19 januari 2006). Van Doorn bewonderde Tromp, zo blijkt uit een stuk dat hij schreef na diens overlijden ('Afscheid van Bart Tromp', Trouw, 23 juni 2007).

\section{Geraadpleegde literatuur}

Cate, A. ten (2007), Sterven voor Bosnië? Een historische analyse van het interventiedebat in Nederland 1992-1995, Amsterdam: Boom.

Doorn, J.A.A. van (1975), 'The Decline of the Mass Army', in: J.A.A. van Doorn, The Soldier and Social Change, Beverly Hills/Londen: Sage, p. 61-64.

Doorn, J.A.A. van (1992), 'Dienstplicht voltooid verleden tijd', HP/De Tijd, 9 oktober 1992.

Doorn, J.A.A. van (1994), 'Militair pacifisme', HP/De Tijd, 16 december 1994.

Doorn, J.A.A. van (1996 [1992]), 'Een pleidooi voor rekolonisatie’, in: J.A.A. van Doorn, De draagbare Van Doorn, Amsterdam: Prometheus, p. 164172.

Doorn, J.A.A. van (1999), 'Vredessoldaten in oorlogsgebied', HP/De Tijd, 26 november 1999.

Doorn, J.A.A. van (2001a), 'De bruuske herontdekking van de Islam', Trouw, 5 oktober 2001.

Doorn, J.A.A. van (2001b), 'Amerikanen houden niet van oorlog', Trouw, 12 oktober 2001.

Doorn, J.A.A. van (2001c), 'De wonderlijke terugkeer van de koloniale idee', Trouw, 23 november 2001.

Doorn, J.A.A. van (2001d), 'Nederland stelt daad van internationale allure', Trouw, 30 november 2001.

Doorn, J.A.A. van (2002a), 'Verenigde Staten staan boven en onder de wet', Trouw, 4 januari 2002. 
Doorn, J.A.A. van (2002b), 'NIOD-rapport: Te laat, te lang en slordig bovendien', Trouw, 17 april 2002.

Doorn, J.A.A. van (2002c), 'Het morele failliet van het Israëlische leger', Trouw, 3 mei 2002.

Doorn, J.A.A. van (2002d), '11 September heeft geen wijsheid gebracht', Trouw, 14 september 2002.

Doorn, J.A.A. van (2002e), Gevangen in de tijd. Over generaties en hun geschiedenis, Amsterdam: Boom.

Doorn, J.A.A. van (2003a), 'Irak bestrijden en bevrijden valt moeilijk te verenigen', Trouw, 29 maart 2003.

Doorn, J.A.A. van (2003b), 'Idealen, met het zwaard verspreid', Trouw, 30 april 2003.

Doorn, J.A.A. van (2005), 'Het Afghaanse opbouwproject is dwaasheid', Trouw, 31 december 2005.

Doorn, J.A.A. van (2006a), 'Naar Afghanistan: Verwarring en verwatenheid', Trouw, 21 januari 2006.

Doorn, J.A.A. van (2006b), 'Fuik', HP/De Tijd, week 24.

Doorn, J.A.A. van (2006c), 'Afghanistan: vlucht naar voren', Trouw, 12 augustus 2006.

Doorn, J.A.A. van (2006d), '11 September: Toen Bush zijn hoofd verloor', Trouw, 9 september 2006.

Doorn, J.A.A. van (2006e), 'Kamp Holland in de Tartaarse woestijn', Trouw, 16 september 2006.

Doorn, J.A.A. van (2006f), 'G.W. Bush: Het totale debacle', Trouw, 14 oktober 2006.

Doorn, J.A.A. van (2007a), 'Afghanistan is een onmogelijk ontwikkelingsproject', Trouw, 3 februari 2007.

Doorn, J.A.A. van (2007b), 'Het gaat mis in Afghanistan', Trouw, 20 april 2007.

Doorn, J.A.A. van (2007c), 'De nervositeit over Afghanistan', Trouw, 28 april 2007.

Doorn, J.A.A. van (2007d), 'Oorlog als wetenschappelijk thema', Trouw, 14 juli 2007.

Doorn, J.A.A. van (2008), 'In de fuik van een gewelddadig avontuur met neokoloniale ambities', NRC Handelsblad, 19 januari 2008.

Doorn, J.A.A. van (2009), Nederlandse democratie. Historische en sociologische waarnemingen, Amsterdam: Mets \& Schilt.

Doorn, J.A.A. van (2009 [1999]), 'De eeuw van het Grote Sterven', in: J.A.A. van Doorn, Nederlandse democratie. Historische en sociologische waarnemingen, Amsterdam: Mets \& Schilt, p. 369-384.

Doorn, J.A.A. van en W.J. Hendrix (1983), Het Nederlands/Indonesisch conflict. Ontsporing van geweld, Dieren: De Bataafsche Leeuw.

Doorn, J.A.A. van en J.H. Mans (1968), 'United Nations Forces. On Legi- 
timacy and Effectiveness of International Military Operations', in: J.A.A. van Doorn (red.), Armed Forces and Society. Sociological Essays, The Hague: Mouton, p. 345-376.

Groen, P.H.M. (1991), Marsroutes en dwaalsporen. Het Nederlands militair-strategisch beleid in Indonesië, Den Haag: Sdu.

Janowitz, M. (1971 [1960]), The Professional Soldier. A Social and Political Portrait, New York: Free Press.

Nederlands Instituut voor Oorlogsdocumentatie (2002), Srebrenica. Een 'veilig' gebied, Amsterdam: NIOD.

Scagliola, S. (2002), Last van de oorlog. De Nederlandse oorlogsmisdaden in Indonesië en hun verwerking, Amsterdam: Balans.

Schaberg, J. (2007), 'Toon vastberadenheid in Uruzgan, net als Australië', Trouw, 25 april 2007.

Schijf, H. (2008), 'Van Doorns Indische lessen', Mens en maatschappij 83: 210-212.

Tromp, B. (1996), Verraad op de Balkan. Een kroniek, Nieuwegein: Aspekt. 
DeelV

Van Doorn en de hedendaagse sociologie 



\title{
10 J.A.A. van Doorn en de moderne sociologie
}

\section{Het einde van een intellectuele traditie}

\author{
Dick Houtman ${ }^{1}$
}

Je mehr der Intellektualismus (...) die Vorgänge der Welt 'entzaubert' (...) (wodurch sie) ihren magischen Sinngehalt verlieren, nur noch 'sind' und 'geschehen', aber nichts mehr 'bedeuten', desto dringlicher erwächst die Forderung an die Welt (...) daß sie bedeutungshaft und 'sinfoll' geordnet (sei). (Max Weber 1920-1921: 308)

If sociology could speak it would say, 'I am tired'.

(Jeffrey Alexander 1982: xiii)

\section{Inleiding}

Een halve eeuw geleden verschenen twee boeken die de Nederlandse sociologie diepgaand hebben beïnvloed: Moderne sociologie van Van Doorn en Lammers (1959) en The Sociological Imagination van Charles Wright Mills (1959). Het eerste blaakte van het intellectuele zelfvertrouwen en voerde een pleidooi voor een volwassen wetenschappelijke sociologie. Het tweede preludeerde op een crisis in het vak die in de jaren zestig zou losbarsten (Gouldner 1970), die Alexander tot de hierboven aangehaalde verzuchting verleidde, en die volgens gezaghebbende waarnemers van uiteenlopende sociologische snit nooit meer is overgegaan (bijvoorbeeld Black 2000; Horowitz 1993; Lemert 1995; Lopreato en Crippen 1999; Seidman 1994; Turner 1992). Mills overleed drie jaar na de publicatie van zijn boek op 45-jarige leeftijd aan zijn tweede hartaanval, maar Van Doorn leefde nog lang en gelukkig. Hij leidde tot zijn dood op 14 mei 2008 een lang en intellectueel vruchtbaar leven, waarin hij zijn opvattingen over de sociologie mettertijd op essentiële punten heeft bijgesteld en steeds meer afstand heeft genomen van het type sociologie dat hij in 1959 nog vol overtuiging had bepleit. 
Van Doorns overlijden vormt dan ook een uitgelezen aanleiding om terug te blikken op de ontwikkeling van de Nederlandse sociologie in de afgelopen halve eeuw en te reflecteren op haar toekomst. Ik meen met Van Doorn dat de sociologie in dit land de afgelopen decennia verregaand is verschraald. Grootschalig surveyonderzoek en geavanceerde statistische methoden zijn steeds meer maatgevend geworden en de bereidheid om nog te aanvaarden dat er legitieme onderzoeksvragen bestaan die andere typen data, methoden en technieken vereisen, lijkt steeds verder afgenomen (bijvoorbeeld Van Tubergen (2008), maar dit voorbeeld laat zich moeiteloos aanvullen met een lange reeks andere publicaties en referentenrapporten van artikelen en onderzoeksvoorstellen). De neiging om de eigen intellectuele identiteit overwegend nog in methodologische termen te definiëren, heeft echter niet alleen bedenkelijke gevolgen voor de omgang met intellectuele diversiteit. Het op deze wijze ondergeschikt maken van doelen aan middelen heeft er ook toe geleid dat de sociologisch-theoretische kennisverwerving steeds verder is verdwenen in een dikke mist van relaties tussen variabelen die niets meer betekenen voor de houdbaarheid van welke theorie dan ook. Dat is naar mijn oordeel het grote tekort van de Nederlandse sociologie: zij is zichzelf steeds meer verloren in data en statistiek en gaat voor wat betreft de bijdrage aan de theorievorming steeds vaker vrijwel nergens meer over.

De intellectuele agenda die Van Doorn een halve eeuw terug voor de sociologie ontvouwde, vormt bij uitstek een geschikt startpunt voor een analyse van deze ontwikkeling, al is het maar omdat Van Doorn hierover zelf steeds pessimistischer is geworden. Aan sociologisch werk dat zich aan de genoemde ontwikkeling onttrekt, ga ik hier verder dus geheel voorbij, zodat mijn analyse keurig eenzijdig is - zoals dat nu eenmaal hoort bij een wetenschappelijke analyse (Weber 1951 [1922]). Ik heb geprobeerd om het noemen van namen van Nederlandse vakgenoten tot een minimum te beperken, want dat leidt toch alleen maar tot gezeur over casuïstieke bijzaken en wekt bovendien de onjuiste indruk dat ik op de $\operatorname{man}(\mathrm{m} / \mathrm{v})$ in plaats van de bal wil spelen, wat geenszins het geval is. Evenmin wil ik de onjuiste indruk wekken dat ik de hier geproblematiseerde radicale empirische wending in de Nederlandse sociologie 'alleen maar slecht vind', want ook dat is al niet het geval. Ik ben weliswaar kritisch over de wijze waarop een en ander in de praktijk gestalte krijgt, maar onderschrijf volledig en onverkort de ambitie die eraan ten grondslag ligt: het radicaal zuiveren van de sociologie van als wetenschap vermomde politieke praatjesmakerij.

Wat volgt dient kortom te worden begrepen als een oproep tot discussie aan Nederlandse sociologen door iemand die de afgelopen twintig jaar van een brede baaierd aan methodologische, theoretische en the- 
matische borden heeft gegeten, zich erover verbaast dat hij inmiddels buiten zijn directe onderzoeksomgeving aan de EUR op onderzoeksgebied vrijwel uitsluitend nog samenwerkt met niet-sociologen, en inmiddels een koers heeft ingezet die veel Nederlandse sociologen niet eens meer als sociologie lijken te (h)erkennen. Voor degenen die de sociologie een warm hart toedragen, lijken mij dit ontwikkelingen om zich zorgen over te maken. Hoe heeft het zo ver kunnen komen dat iemand die zich onder het motto 'intellectuele bekrompenheid is altijd slecht' op cruciale onderdelen kan identificeren met een breed scala aan theoretische en methodische benaderingen zich in de Nederlandse sociologie niet langer thuis voelt?

Om het antwoord op die vraag te vinden, zet ik in wat volgt eerst uiteen dat er wat mij betreft niet veel van Van Doorns programma is terechtgekomen, analyseer ik vervolgens aan de hand van de in de jaren zestig uitgebroken crisis binnen het vak hoe dat te begrijpen valt, en leg ik ten slotte uit waarom in dit licht beschouwd de cultuursociologie een aantrekkelijke uitweg uit de malaise biedt. Ik besluit met enkele overwegingen over de maatschappelijke betekenis van het vak in het licht van de geschetste ontwikkelingen.

\section{Opkomst en ondergang van de moderne sociologie}

\section{Inleiding}

Van Doorn nam een halve eeuw geleden afstand van twee tot op dat moment in Nederland invloedrijke sociaal-wetenschappelijke tradities: de sociografische en de cultuursociologische. De eerste was naar zijn oordeel te beschrijvend en te weinig gericht op theorievorming en theorietoetsing en de tweede werd volgens hem al te zeer gekenmerkt door moralistische beschouwingen door sociologen van overwegend confessionele huize. Met deze dubbele grensafbakening trad Van Doorn (1964: 55 ) in het voetspoor van de moderne Amerikaanse sociologie van destijds, waarbij hij vooral Robert Mertons vaak herdrukte pleidooi voor sociologische theorieën van middelbare reikwijdte en cumulatie van wetenschappelijke kennis via wederzijdse bevruchting van theorievorming en empirisch onderzoek ter harte nam (bijvoorbeeld Merton 1969). De verwantschap met Mills' (1959) afwijzing van enerzijds 'grand theory' en anderzijds 'abstracted empiricism' is uiteraard eveneens evident.

\section{Moderne sociologie I: gemoraliseer is geen wetenschap}

Merton verwierp brede sociologisch-theoretische interpretatiekaders, waarmee men welbeschouwd alles wel kan interpreteren, en die om die 
reden noch empirisch kunnen worden bevestigd, noch weerlegd. Dergelijke 'theoretische perspectieven' of 'totale sociologische systemen' verschillen eenvoudigweg onvoldoende van politieke ideologieën of zingevingssystemen: men kan ze sympathiek of onsympathiek, verwerpelijk of waardevol, mooi of lelijk vinden, maar men kan niet aantonen dat ze 'waar' of 'onwaar' zijn. De verwantschap met Van Doorns afwijzing van de cultuursociologie is evident, zoals bijvoorbeeld blijkt uit diens karakterisering van de laatste als 'dat merkwaardige en bewerkelijke grensgebied tussen wetenschap en visie, tussen nuchterheid en pathos', dat 'een golf in de Europese zee van al dan niet profetisch cultuurpessimisme' behelsde en waarvoor volgens hem 'de retorische traditie van ons "domineesland” (...) (overvloedig) aanknopingspunten (bood)' (1964: 91-92).

In deze context valt meestal de naam van de Groningse cultuursocioloog Bouman (bijvoorbeeld Van Doorn 1964: 92), maar ook Van Doorns bespreking van een proefschrift van Litjens over 'onmaatschappelijke gezinnen' in het eerste nummer van de Sociologische gids uit 1953 maakt prima duidelijk welke bezwaren hij tegen een dergelijk type sociologie had. Hij stelt in zijn bespreking vast dat het hier gaat om 'Een studie die vanuit een zeer bepaalde levensbeschouwelijke visie de concrete werkelijkheid beoordeelt, resp. veroordeelt' (1953b: 132) en daarmee sociologie dus vermengt met oordelen 'vanuit het mensbeeld van de rooms-katholiek Litjens' (idem: 133). Aan het slot van zijn betoog beland, werpt Van Doorn de vraag op waarom 'sociale desintegratie' als gevolg van onkerkelijkheid eigenlijk zou moeten worden opgevangen door kerkelijk opbouwwerk, zoals bepleit door Litjens, en niet door bijvoorbeeld communistische organisaties. Men kan wat Van Doorn betreft namelijk met evenveel recht beweren 'dat de kerk een sociaal-conserverend en dus een sociaal "ongezond" element is' (idem: 134), wat hem ten slotte tot zijn eindoordeel brengt: 'Dit alles zijn oordelen die rechtstreeks voortvloeien uit diagnostische, ethische en politieke overwegingen, en die van gelijke waarde - of onwaarde - zijn in het aangezicht der sociologisch geanalyseerde werkelijkheid' (idem: 134).

Men beweert over Van Doorns relativering van wetenschap en rationaliteit vanaf de jaren tachtig wel dat hij hiermee 'almaar dichter in de buurt (kwam) van het soort Duits-Europese, conservatieve contraVerlichting sociologie à la Bouman dat hij aanvankelijk verfoeide' (Van der List 1996: 15), maar dat lijkt mij toch wat al te kort door de bocht. Natuurlijk koketteerde Van Doorn graag met het conservatisme (1996: 199-213), natuurlijk heeft hij steeds meer afstand genomen van het positivisme waarin hij in zijn jonge jaren nog zo had geloofd (idem: 34-44) en natuurlijk had hij zich gestoord aan 'de jongelui die in de jaren zestig en zeventig een ogenblik de waarheid en De Waarheid in pacht hadden' (idem: 140), maar dat alles onderstreept wat mij betreft toch vooral zijn 
trouw aan zijn vroegste opvattingen over de verhouding tussen wetenschap en moraal. Van Doorn is gewoon al die tijd een tegenstander gebleven van als wetenschap vermomd moralisme, of dat nu een rechtse gedaante aannam, zoals ten tijde van de verzuiling (idem: 37-38), of een linkse, zoals in de jaren zestig en zeventig (idem: 133-141).

Deze aversie tegen het vermengen van wetenschap en moraal is een constante in het werk van Van Doorn gebleven. Zij leidde hem vanaf het midden van de jaren tachtig tot een relativering van wetenschap en rationaliteit en tot schatplichtigheid aan postmodernisten als Zygmunt Bauman $(1987,1992)$ en Stephen Toulmin (1990), die in dezelfde periode evenzeer een oneigenlijk politiek gebruik van wetenschap problematiseerden. Aan het slot van zijn inaugurele rede bij de aanvaarding van de buitenlandse Francqui-leerstoel 1993-1994 aan de universiteit van Antwerpen haalt Van Doorn Bauman dan ook met instemming aan waar hij concludeert dat 'intellectuelen (...) niet langer kunnen poseren als hoge vertegenwoordigers van de Wetgevende Rede die de ervaringswijsheid van de gemiddelde burger bij voorbaat afdoen als een manifestatie van vooroordelen, onbegrip en onwetendheid' (1996: 274).

Elders leidt een hiermee nauw verwante baumaniaanse weerzin tegen het verwarren van sociaal-wetenschappelijke theorieën met de sociale werkelijkheid hem tot de stelling dat 'in de sociale wetenschappen (...) het gevaar (dreigt) dat men zich, elkaar becommentariërend, verwijdert van de samenleving, en in een verlangen naar "echte" wetenschap, de constructies en modellen voor de werkelijkheid gaat aanzien', om daar spottend aan toe te voegen dat 'Rawls, Habermas of Lyotard, hoe vernuftig hun systemen ook zijn, (...) in hun cerebrale verhevenheid even ver van de gemiddelde burger (staan) als Schillebeeckx van de gelovige christenen' (1996: 222). Van Doorns relativering van wetenschap en rationaliteit vanaf de jaren tachtig behelst kortom geen terugkeer naar het type cultuursociologie dat hij in de jaren vijftig nog had verworpen, want er gaapt een aanzienlijke intellectuele kloof tussen de postmoderne Bauman en diens cultuursociologische Nederlandse bijna-naamgenoot van destijds. De opkomst van het postmodernisme in de afgelopen halve eeuw heeft het intellectuele landschap dusdanig opgeschud dat zo'n relativering van wetenschap en rationaliteit vandaag de dag niet langer kan worden afgedaan als 'conservatisme'.

Moderne sociologie II: data en methoden alleen maken nog geen wetenschap Van Doorn wilde het vak destijds niet alleen bevrijden van als wetenschap vermomde politieke praatjes, maar had in samenhang daarmee een sociologie op het oog die geleid door systematisch empirisch onderzoek tot theoretisch inzicht zou komen. Hiermee trad hij al evenzeer 
in het voetspoor van Merton, die immers uitvoerig heeft betoogd dat men in onderzoek vastgestelde 'empirische generalisaties', patronen van samenhang tussen variabelen, niet moet verwarren met sociologischtheoretisch inzicht (Merton 1968: 150).

Although propositions of this order are essential in empirical research, a miscellany of such propositions only provides the raw materials for sociology as a discipline. (...) The notion of directed research implies that (...) empirical inquiry is so organized that if and when empirical uniformities are discovered, they have direct consequences for a theoretic system. In so far as the research is directed, the rationale of findings is set forth before the findings are obtained.

Het kost weinig moeite om de overeenkomst met Van Doorns afwijzing van de sociografie te bespeuren: een intellectueel volwassen sociologie moet niet simpelweg feiten op elkaar stapelen, maar moet ze synthetiseren in theorieën, waaruit dan vervolgens weer nieuwe hypothesen kunnen worden afgeleid en getoetst. Evenmin kost het veel moeite om de verwantschap met Mills' kritiek op 'abstracted empiricism' te ontwaren: een intellectueel serieus te nemen sociologie moet meer doen dan alleen maar met geavanceerde statistische methoden relaties tussen variabelen vaststellen.

De sociologische hamvraag is in deze optiek dus niet simpelweg welke relaties er tussen variabelen bestaan (een strikt methodologische kwestie), maar vooral wat deze relaties eigenlijk betekenen voor de houdbaarheid van welke sociologische theorieën (een theoretische kwestie). Relaties tussen variabelen zijn vanuit dit gezichtspunt bezien kortom niet meer dan data, terwijl het empirisch onderzoek gericht dient te zijn op het achterhalen van hun implicaties voor de houdbaarheid van sociologische theorieën. De klassieke status van Durkheims werk over de verschillende zelfmoordcijfers in protestantse en katholieke gebieden, om maar naar het meest voor de hand liggende voorbeeld te grijpen, is bijvoorbeeld niet te danken aan Durkheims 'ontdekking' van dit destijds reeds bekende patroon, maar slechts aan zijn expliciet sociologisch-theoretische interpretatie ervan, alsmede de wijze waarop hij die systematisch probeert te toetsen.

Wie deze road map voor een wetenschappelijke sociologie volgt, moet vooral ook de sociologisch-theoretische common sense stevig aan de tand voelen: dat wat iedere socioloog weet (of meent te weten, of eigenlijk alleen maar gelooft - gewoon, omdat de anderen dat ook doen). Het gaat hierbij om al die theoretische veronderstellingen en interpretaties waarvan sociologen bijna zijn vergeten dat het veronderstellingen en inter- 
pretaties zijn en die als zodanig kritiekloos worden gereproduceerd. Een paar voorbeelden uit eigen keuken van het kritisch beproeven van dergelijke sociologische common sense ideeën: betekent het feit dat 'de arbeidersklasse' wordt gekenmerkt door zowel economisch egalitarisme als autoritarisme eigenlijk wel dat beide typen opvattingen op vergelijkbare wijze kunnen worden verklaard uit iemands 'klassenpositie' (Houtman 2003a)? Betekent de erosie van het vertrouwde patroon van een links stemmende arbeidersklasse en een rechts stemmende middenklasse eigenlijk wel dat het klassengebonden stemgedrag steeds verder is afgekalfd (Van der Waal et al. 2007)? En betekent de gestage afname van het aantal christenen in Nederland eigenlijk wel dat er in dit land sprake is van een ondubbelzinnig proces van secularisering (Houtman en Mascini 2002; Houtman 2008a; Achterberg et al. 2009)? Anders dan de meeste vakgenoten lijken te geloven luidt het antwoord op al deze drie vragen: 'Nee, dat betekent het helemaal niet.'

En dat betekent dan zelf natuurlijk wel weer iets, namelijk dat sociologen al te vaak genoegen nemen met het vaststellen van relaties tussen variabelen, zonder zich veel gelegen te laten liggen aan de vraag wat deze relaties eigenlijk betekenen voor de (on)houdbaarheid van welke sociologische theorieën. Dat was ook ongeveer de klacht van Van Doorn over de Nederlandse sociologie, net overigens als die van de Groningse socioloog Rafael Wittek, die alweer enkele jaren terug in een co-referaat vaststelde dat veel van zijn collega-sociologen zijn veranderd in een soort 'boekhouders'. En inderdaad: binnen de neopositivistische hoofdstroom van het vak heeft men steeds meer afscheid genomen van de sociologische theorie, zodat tegenwoordig in onderzoek vooral nog effecten van variabelen op andere variabelen worden vastgesteld, zonder dat die nog veel serieus te nemen implicaties hebben voor de houdbaarheid of onhoudbaarheid van sociologische theorieën. Deze radicale empirische wending lijkt mede de populariteit van algemene gedragstheorieën als de rationele-keuzetheorie te verklaren, want dergelijke theorieën zijn net zomin empirisch weerlegbaar als de abstracte en algemene theorieen die Van Doorn, Merton en Mills destijds al met scepsis bezagen. Ze verschaffen daarmee een prima alibi om zich over de theoretische implicaties van kwantitatief survey-onderzoek niet langer erg druk te maken.

De hyperbolische titel van een artikel in voorbereiding op de website van een collega is ongetwijfeld bedoeld als ludiek protest tegen deze trend, maar demonstreert desondanks uitstekend tot wat voor artikelen een en ander in toenemende mate leidt: 'Individual and Contextual Effects of Variables on Other Variables in 278 Countries: Multilevel Multinomial Logistic Modelling by Means of the New BULLSHIT Software'. De grote vorderingen in de sfeer van de kwantitatieve data-analyse zijn binnen de Nederlandse sociologie kortom steeds meer ten koste gegaan 
van de theoretische kwaliteit en relevantie van het verrichte onderzoek en het behoeft uiteraard geen betoog dat meer exploratief, kwalitatief en theorievormend onderzoek hierdoor helemaal steeds verder in de verdrukking is geraakt.

\section{Een discipline in crisis}

\section{Inleiding}

Wij moeten vijftig jaar na dato vaststellen dat er van de destijds door Van Doorn bepleite cumulatie van sociologisch-theoretisch inzicht via wederzijdse bevruchting van theorievorming en empirisch onderzoek niet veel is terechtgekomen. Nederlandse sociologen gebruiken de sociale werkelijkheid nauwelijks meer dan destijds als proeftuin voor de vaststelling van de houdbaarheid van sociologische theorieën. Natuurlijk zijn zij steeds vaker hypothesen gaan toetsen, maar de resultaten daarvan maken het helaas zelden mogelijk om uitspraken te doen over de houdbaarheid van empirisch weerlegbare sociologische theorieën. Wat Van Doorn in het eerste nummer van de Sociologische gids de sociografie verweet, is daarmee ook in hoge mate van toepassing op de hedendaagse sociologie: 'weinig méér (...) dan een inventarisatie van feiten zonder doelgerichte selectie en deskundige verwerking' (1953a: 1).

De gevoelens van malaise in de Nederlandse sociologie zijn uiteraard geen strikt nationale aangelegenheid, want ook buitenlandse waarnemers wijzen erop dat het vak vanaf de jaren zestig in de versukkeling is geraakt (bijvoorbeeld Black 2000; Horowitz 1993; Lemert 1995; Lopreato en Crippen 1999; Seidman 1994; Turner 1992). Zij verschillen interessant genoeg scherp van mening over de vraag of de in het voorgaande geschetste ontwikkeling (waarvan men ook in bijvoorbeeld Oxford en Mannheim trouwens wel pap lust) een oorzaak van of een oplossing voor deze intellectuele malaise vormt. Naar mijn oordeel is zij geen van beide, want is de crisis van de sociologie niets anders dan het tragische gevolg van het proces dat Max Weber aanduidde als de 'onttovering van de wereld'. Dit proces heeft niet alleen verregaande gevolgen voor het religieuze domein gehad, maar ook voor het intellectuele, waar het via de opkomst van het postmodernisme de kloof tussen science en humanities aanzienlijk heeft verbreed (denk aan de zogenoemde science wars) en de sociologie uiteen dreigt te doen vallen langs deze intellectuele breuklijn die zij ooit als 'derde cultuur' (Lepenies 1988) nog hoopte te kunnen overbruggen (Houtman 2003C). Ik behandel hieronder dan ook eerst Van Doorns diagnose van de crisis van de sociologie en vervolgens die van mijzelf, waarbij ik een lans breek voor wat ik persoonlijk beschouw als de beste uitweg uit de ontstane malaise: het tot bloei brengen van een wat eigentijdsere cultuursociologie dan het type dat Van Doorn destijds verwierp. 


\section{Van Doorn over individualisering en sociologie}

Hoewel Van Doorn zacht gezegd geen liefhebber was van het verzuilde bestel (1996: 37-38), was de samenleving destijds volgens hem wel overzichtelijker dankzij wat hij 'harde normatieve structuren' noemde. Inmiddels bestaan dergelijke structuren volgens hem echter nauwelijks nog (Van Doorn 1996: 123).

Als er geen krachtige politieke en maatschappelijke stromingen meer zijn, geen kerken en partijen die zich uitdrukkelijk profileren, dan blijft er voor het grote publiek weinig anders over dan nu en dan een vinger in de lucht te steken om te voelen waar de wind vandaan komt.

In zijn voor zover ik heb kunnen nagaan laatste publicatie over de betekenis van de sociale wetenschappen stelt hij het volgende vast (Van Doorn 2000: 33-34):

Vrijwel overal is sprake van een zekere mate van sociale fragmentatie, snel wisselend gedrag en verhoogde subjectivering in het maatschappelijk verkeer, als gevolg waarvan het sociaal-wetenschappelijk denken in termen van instituties en structuren min of meer outdated lijkt te zijn geworden. (...) Tal van institutionele verbanden zijn losser en minder verplichtend geworden, zoals het geval is bij families, verenigingen, kerk en staat. (...) Individuele vrijheid, vooral keuzevrijheid, is een nagenoeg onaantastbaar recht geworden.

Van Doorns stelling luidt, kort en goed, dat de samenleving verregaand is geïndividualiseerd en dat het individuele handelen daardoor steeds meer is losgeweekt uit de structuren en instituties die het ooit sociologisch analyseerbaar maakten. 'Individuele vrijheid, vooral keuzevrijheid' is volgens Van Doorn dus weliswaar 'een nagenoeg onaantastbaar recht geworden', maar die gedeelde overtuiging kan het sociale leven volgens hem blijkbaar desondanks niet van zoveel structuur voorzien dat het sociologisch analyseerbaar blijft (Duyvendak 2004; Houtman 2008b). Deze merkwaardige gedachte komt voort uit de veronderstelling dat cultuur slechts een 'bijzaak' is, niet meer dan een 'afgeleide' of 'gevolg' van 'iets echters' en 'iets fundamentelers' dat haar 'bepaalt' en dus zelf logischerwijze niet cultureel van aard kan zijn. Met deze veronderstelling staat Van Doorn bepaald niet alleen, want binnen de sociologie bestaat een lange en intellectueel dominante traditie die er, zoals Jeffrey Alexander (2003: 13) het verwoordt in zijn pleidooi voor een 'strong program in 
cultural sociology', vanuit gaat dat 'explanatory power lies in the study of the "hard" variables of social structure, such that structured sets of meanings become superstructures and ideologies driven by these more "real" and tangible social forces', waarbij cultuur dus 'becomes defined as a "soft", not really independent variable: it is more or less confined to participating in the reproduction of social relations'.

\section{Een 'echte' en een 'onechte' sociale werkelijkheid?}

Deze gedachte dat cultuur de 'echte' sociale werkelijkheid slechts kan versluieren en dus niet meer dan een 'afhankelijke' variabele kan zijn, leidt er binnen de neopositivistische hoofdstroom toe dat de door onderzochten toegekende culturele betekenissen zoveel mogelijk worden gemarginaliseerd om tot een zo 'objectief' mogelijke weergave van een 'echte' sociale werkelijkheid te komen (Nijhof 2008). Men kiest dus als 'onafhankelijke variabelen' liever voor 'objectieve posities' dan voor 'subjectieve opvattingen' en prefereert als afhankelijke variabelen 'harde gedragsvariabelen' boven 'vluchtige attitudes'. En uiteraard ligt de notie dat cultuur niet meer is dan een 'afgeleide' of 'gevolg' van 'iets echters' en 'iets fundamentelers' ook ten grondslag aan al die Marxist-lite theorieën, volgens welke 'het culturele' niet anders dan een 'gevolg' van 'het economische' kan zijn (de welvaart, de armoede, de klassenpositie, de economische belangen, of vul verder maar iets in). Zo beweren theorieën die door velen serieus worden genomen dat het belang dat mensen hechten aan individuele vrijheid en aanvaarding van cultureel verschil wordt bepaald door de klassenpositie die zij innemen (Lipset 1981; Kohn 1977 [1969]; Kohn en Slomczynski 1990) dan wel de welvaart waaronder zij als kind zijn opgegroeid (Inglehart 1977).

Dat er voor deze theorieën geen spoor van bewijs bestaat (Houtman 2003b), onderstreept slechts hoezeer sociologen de gedachte dat 'het culturele wordt bepaald door het economische' als een waarheid als een koe beschouwen. En suggereert empirisch onderzoek dan toch iets anders, bijvoorbeeld dat wat mensen doen of vinden niet uit hun beroep kan worden verklaard, dan betekent dat in de ogen van sociologen al snel dat de beroepen 'verkeerd' worden ingedeeld, zodat nauwgezet moet worden onderzocht welke indeling van beroepen de meeste variantie verklaart (Houtman 2000: 13-14, 133-135). Een ander voorbeeld, ten slotte, is de 'etnische competitietheorie', volgens welke etnocentrisme binnen een 'autochtone ingroup' het gevolg is van de ervaring van economische concurrentie door een 'allochtone outgroup' (Eisinga en Scheepers 1989). Ook voor de houdbaarheid van deze theorie bestaat geen spoor van bewijs, want het vooral onder laagopgeleiden voorkomende etnocentrisme kan niet worden toegeschreven an het zich 'economisch 
bedreigd voelen', al proberen de genoemde onderzoekers zichzelf van het tegendeel te overtuigen via een operationalisering van 'ervaren concurrentie' die men net zo goed 'racisme' zou kunnen noemen (Elchardus en Siongers 2009: 21-23; Houtman 1994: 72-95, 143-183, 201).

En wat daar dan natuurlijk nog bijkomt is het wereldvreemde onderscheid tussen een 'nationale ingroup van autochtone Nederlanders' en een 'outgroup van in Nederland aanwezige etnische minderheden' (en uiteraard: de veronderstelling dat dit onderscheid niet bestaat is precies even wezenloos). Dit soort rare veronderstellingen hebben sociologen die bereid zijn om cultuur serieus te nemen helemaal niet nodig, want zij kunnen de eigen fantasie gewoon vervangen door de werkelijkheid: de door de onderzochten zelf toegekende betekenissen (Houtman 1994: 20o). Zelfs nu onderzoekers inmiddels overtuigende onderzoeksresultaten boeken met culturele verklaringen voor etnocentrisme (Sniderman et al. 2003; Elchardus en Siongers 2009) wordt de 'etnische competitietheorie' echter nog steeds kritiekloos rondgepompt. Dat komt naar te vrezen valt doordat veel sociologen gewoon niet willen geloven dat cultuur meer kan zijn dan een 'afhankelijke variabele' die wordt 'verklaard' door 'iets economisch'.

Een laatste grappig gevolg van de gedachte dat 'het culturele' altijd en onvermijdelijk wordt bepaald door 'het economische' is het nauwelijks verholen enthousiasme over 'de economische crisis' onder sociologen - en trouwens ook onder sociaal-democraten (Houtman en Achterberg 2009). Sociologen grijpen de crisis met graagte aan om met Van Doorn te kunnen blijven geloven dat er niet zozeer iets mis is met de (moderne) sociologie, als wel met de hedendaagse samenleving. Want wanneer zij maar ernstig genoeg wordt, zo werd mij sinds het najaar van 2008 door verschillende collega's met een mengeling van hoop en vertrouwen verzekerd, dan zal de crisis 'de mensen in de samenleving' uiteindelijk wel weer doen inzien waar het 'eigenlijk' of 'echt' om gaat. Dan zal het sociale leven weer 'gewoon' worden en dus sociologisch analyseerbaar. De nu PVV-stemmende laagopgeleiden zullen van hun dwaalwegen terugkeren in de schoot van de sociaal-democratische moederkerk en ook al die anderen die van hun vroegere institutionele ankers zijn losgeslagen, zullen zich weer gewoon conform hun 'echte' belangen of sociale rollen gaan gedragen.

\section{Op jacht naar onttoverde sociologie}

De sociologie sinds de jaren zestig

Men kan natuurlijk ook gewoon in Sinterklaas geloven, want zo simpel als deze sociologische cargo cult het voorstelt, is het helaas niet. Het lijkt 
mij dan ook een stuk verstandiger - een stuk wetenschappelijker ook als sociologen de hand eens wat kritischer in eigen boezem steken. Zo'n zelfreinigende exercitie moet uiteraard beginnen met de vraag wat er sinds de jaren zestig eigenlijk precies is misgegaan met de sociologie. In nauwe samenhang met het culturele en politieke klimaat verloren de dominante instituties van de burgerlijke prestatiemaatschappij destijds in rap tempo hun vroegere legitimiteit (Roszak 1969; Zijderveld 1970), waardoor intellectuele onvrede ontstond over sociologische analyses waarin ze desondanks als 'normaal', 'natuurlijk' en 'onontkoombaar' werden voorgesteld (bijvoorbeeld Mills 1963 [1943]; Becker 1967; Gouldner 1970). Hierdoor kwamen de verhouding tussen sociologie en moraal, tussen waarden en wetenschap, en bijgevolg ook de status van het vak als 'echte' wetenschap, in het brandpunt van het sociologisch debat te liggen (bijvoorbeeld Gouldner 1962; Oakes 1975). Dit alles leidde tot een verregaande politisering en intellectuele verslonzing van het vak die geen einde maakte aan de vermenging van sociologie en moraal, maar dit probleem welbeschouwd alleen nog maar groter maakte.

Inmiddels zijn we een paar decennia verder, is het stof van destijds wel zo'n beetje neergedaald en kan dus een balans worden opgemaakt. Zo'n exercitie voert mij tot de conclusie dat sociologen sindsdien op grofweg twee verschillende manieren hebben geprobeerd om hun vak van als wetenschap vermomd gemoraliseer te zuiveren (Houtman 2003c). Enerzijds zijn (vooral buiten Nederland) constructivistische benaderingen tot bloei gekomen, gebaseerd op de veronderstelling dat het sociale leven eenvoudigweg nooit een 'objectieve' betekenis heeft, zodat alleen maar kan worden onderzocht welke uiteenlopende betekenissen uiteenlopende sociale groepen in uiteenlopende samenlevingen en uiteenlopende historische perioden eraan toekennen (bijvoorbeeld Spector en Kitsuse 1977). Anderzijds is er de neopositivistische benadering, waarbinnen men (vooral ook in Nederland) als reactie op de politisering van het vak destijds steeds terughoudender is geworden met het interpreteren van vastgestelde empirische patronen. Men is bijgevolg in deze kringen in toenemende mate alleen nog maar effecten van variabelen op andere variabelen gaan vaststellen, zonder dat die nog veel implicaties hebben voor de houdbaarheid of onhoudbaarheid van welke sociologische theorie dan ook.

Dat constructivisme en neopositivisme steeds vijandiger tegenover elkaar zijn komen te staan, is kortom niet vrij van ironie, omdat beide ondanks hun evidente verschillen uiteindelijk op precies hetzelfde doel zijn gericht: het uitbannen van misplaatste pogingen om een objectieve 'zin' of 'betekenis' aan het sociale leven toe te kennen c.q. het afschaffen van beweringen over wat empirische vaststellingen en maatschappelijke verschijnselen 'eigenlijk' of 'echt' betekenen. Als de wetenschap 
de wereld moet onttoveren (Max Weber zegt ja, ja, ja!) en als deze onttovering van de wereld er vervolgens toe leidt dat de dingen wel blijven bestaan, maar steeds meer hun betekenis verliezen (en Weber zegt alweer ja, ja, ja!), dan moeten de sociologen inderdaad eens ophouden met fantaseren over wat de dingen 'echt' of 'eigenlijk' betekenen. Wetenschappelijk gezien 'betekenen' ze immers helemaal niets, maar 'bestaan' ze alleen maar (Weber 1972 [1920-1921]: 308, 1951 [1922]).

Afgezien van degenen die de zoektocht naar waarheid met liefde offeren op de rechtse of (vaker) linkse altaren van het debat over de multiculturele samenleving, zijn er tegenwoordig op het eerste gezicht niet zoveel sociologen meer over die nog geloven dat zij op grond van sociaal-wetenschappelijke theorieën of empirisch onderzoek uitspraken kunnen doen over wat de dingen 'echt' betekenen c.q. over wat moreel laakbaar en moreel juist is. Maar voor wie wat strenger in de leer is, is er weinig reden om zelfgenoegzaam te zijn over het wetenschappelijke gehalte van de sociologie, want er wordt nog steeds op kritiekloze wijze van alles rondgepompt dat niets met empirische maatschappijwetenschap te maken heeft. Te denken valt aan de scherp contrasterende ideeen van Marx en Durkheim over hoe 'normaal', 'abnormaal', 'pathologisch' of 'waar' dan wel 'vals' bewust een revolutionaire arbeidersklasse zou zijn. De lezer zal toch met mij eens zijn dat dat niets te maken heeft met empirische maatschappijwetenschap en alles met als wetenschap vermomde politiek (Houtman 2003b: 3-9). Het zijn gewoon waardeoordelen in de zin van Weber (1951 [1922]), die voor zover ik dat heb kunnen nagaan desondanks in geen enkel van de tekstboeken waarmee wij onze eerstejaarsstudenten de grondbeginselen van het vak proberen bij te brengen als zodanig worden ontmaskerd.

\section{Cultuursociologie 2.0}

Als het waar is dat de crisis van de sociologie destijds werd veroorzaakt door de neiging van sociologen om de culturele betekenissen van de onderzochten botweg te vervangen door die van henzelf, en dat dat leidde tot een onverkwikkelijke vermenging van wetenschap en politiek, dan lijkt het mij noodzakelijk om de interpretaties van de onderzochten wat serieuzer te gaan nemen en juist wat terughoudender te worden met het opplakken van allerlei sociologisch-theoretische interpretaties die hieraan volledig voorbijgaan. Dat is, zoals uiteengezet, echter niet de richting waarin het vak zich heeft ontwikkeld, want in werkelijkheid zijn in de Nederlandse sociologie beide typen interpretaties steeds verder naar de achtergrond verdwenen (Nijhof 2008).

Daarmee biedt een herwaardering van de cultuursociologie een aantrekkelijke uitweg, waarbij ik dus niet de moralistische mopperso- 
ciologie voor ogen heb die Van Doorn destijds verwierp, maar een meer eigentijdse remix - een 'cultuursociologie 2.0' die de postmoderne kritiek op constructieve wijze incorporeert, die recht doet aan de door de deelnemers aan het sociale leven toegekende culturele betekenissen, en die een brug probeert te slaan tussen sociologie en cultural studies (Houtman 2008b). Binnen de cultural studies is de uit de hedendaagse sociologie steeds meer verdwenen theoretische verbeeldingskracht immers royaal aanwezig, terwijl de sociologische traditie goede diensten kan bewijzen bij het compenseren van de daar soms geringe aandacht voor systematisch empirisch-theoretisch onderzoek en bij het indammen van de soms sterke neiging tot moraliseren.

Zo'n cultuursociologie 2.0 thematiseert de vraag naar de achtergronden en gevolgen van (veranderende) processen van culturele zingeving. Deze algemene thematiek en de daarmee verbonden benadering zijn op zichzelf natuurlijk helemaal niet bijzonder of origineel (Max Weber (1978 [1904-1905]) deed in zijn studie over de protestantse ethiek al niet anders). Maar binnen de hedendaagse culturele context heeft zo'n onderneming wel een hernieuwde intellectuele urgentie gekregen, juist omdat aldus de weg wordt geopend naar een sociologische analyse van de antinomische en anti-institutionele culturele discoursen die volgens Van Doorn zo'n analyse juist in de weg zouden staan. Deze discoursen behelzen welbeschouwd immers niets meer of minder dan de nieuwe zingevende verhalen die worden opgetrokken op de ruïnes van de oude de 'grote verhalen' waarin wij tegenwoordig volgens Lyotard (1984 [1979]) en de zijnen nauwelijks nog zouden geloven. Ze demoniseren weliswaar allerhande maatschappelijke structuren, instituties en tradities, en zijn doordrenkt door de taal van persoonlijke authenticiteit, emotionalisme en rebels non-conformisme, maar cultuursociologisch beschouwd is er net zo weinig reden om ze te beschouwen als slechts 'voer voor psychologen' als het geval was bij hun levensbeschouwelijke en politieke voorgangers (Houtman 2002, 2006, 2008b).

Omdat dergelijke culturele discoursen verregaande maatschappelijke gevolgen hebben, dienen ze volwaardig onderdeel te zijn van het domein van de sociologie. Ik heb mij de afgelopen tien jaar in Rotterdam dan ook samen met Stef Aupers hard gemaakt voor cultuursociologisch onderzoek naar computer gaming, complottheorieën, spiritualiteit en emoties, nostalgie en authenticiteit, reclame en consumptie, fandom en celebrity culture, et cetera - thema's die te belangrijk zijn om over te laten aan cultural studies, culturele antropologie of communicatiewetenschap. En hoewel ik uiteraard direct toegeef dat dit geen 'echt' (?) wetenschappelijk argument is, stel ik tevens vast dat zeer velen buiten de sociologie dergelijke thema's een stuk interessanter vinden dan de riedel van beleid, bestuur, organisatie, management en een baaierd 
aan hedendaagse sociale problemen waarmee andere sociologen hun vak van maatschappelijke betekenis proberen te voorzien (en waarvoor zo'n argument uiteraard evenmin bestaat). Het is volgens mij gewoon de hoogste tijd voor wat meer leven, plezier en avontuur in de sociologische brouwerij om een einde te maken aan het dorre en stoffige imago van het vak in de ogen van buitenstaanders. Stel uzelf als proef op de som maar eens de vraag of $\mathrm{u} u$ uw eigen kinderen (of, wanneer $\mathrm{u}$ die niet hebt: uw eigen neefjes en nichtjes) zou durven adviseren om toch vooral sociologie te gaan studeren (en geef daarop vooral ook het eerlijke antwoord).

\section{De maatschappelijke betekenis van een in wezen nutteloos vak}

Daarmee beland ik ten slotte bij die andere ambitie die Van Doorn een halve eeuw terug voor de sociologie formuleerde: het vak moest wat hem betreft geen ivoren-torenwetenschap worden, maar ook maatschappelijk een verschil maken. Hij had een sociologie voor ogen die sociale ingenieurs zou afleveren, die op basis van solide wetenschappelijke kennis vorm zouden kunnen geven aan bedrijfs- en overheidsbeleid. Van deze technocratische ambities heeft hij na verloop van tijd steeds meer afstand genomen, het meest uitdrukkelijk in zijn diesrede aan de Erasmus Universiteit in 1976 (1996: 199-213), zijn vervroegde afscheidscollege Relativering van rationaliteit aan dezelfde universiteit (1987), zijn kort na zijn vertrek van de universiteit verschenen boek Rede en macht (1988) en zijn voor zover ik heb kunnen nagaan laatste publicatie over de betekenis van de sociale wetenschappen (Van Doorn 2000). Hoewel Van der Veen (2008: 412; zie ook elders in dit boek) over Rede en macht terecht opmerkt dat de ondertitel beter over een uitleiding dan over een inleiding had kunnen reppen, betekent dit niet dat Van Doorn mettertijd is gaan opteren voor een sociologie zonder maatschappelijke betekenis. In zijn werk kunnen wij veeleer een overgang waarnemen van een praktischinstrumentele beleidssociologie naar een maatschappelijk-reflexieve sociologie of, zo men wil, van een streven naar een betrekkelijk eng gedefinieerde beleidsrelevantie naar een veel breder opgevatte maatschappelijke relevantie.

Vooral na zijn afscheid van de universiteit opereerde Van Doorn als columnist en commentator in deze laatste rol, steeds in staat om met een welgemikte schets en enkele rake typeringen orde in de maatschappelijke chaos te scheppen: demonstrerend hoe schijnbaar gescheiden dingen op een dieper niveau toch met elkaar samenhangen, hoe dingen die verschillend lijken desondanks belangrijke overeenkomsten vertonen, en hoe dingen die op het eerste gezicht identiek lijken bij nader inzien toch verschillend zijn. Terwijl de academische sociologie ver- 
schraalde en verdwaalde in statistisch-methodische fijnslijperij, pronkte Van Doorn in de populaire pers met de veren van zijn sociologisch-theoretische verbeeldingskracht. Bij uitstek in deze laatste periode was Van Doorn voor alles een 'ideeënman', zoals Ellemers hem elders in dit boek trefzeker karakteriseert.

En inderdaad: Van Doorn was niet het type socioloog dat pas iets durfde te beweren na eerst met een handvol aio's en postdocs jarenlang nauwgezet empirisch onderzoek te hebben verricht. En gelukkig maar, want waar men er in de wetenschap welbeschouwd nooit van uit mag gaan de Waarheid in handen te hebben (Popper), brengt men zichzelf daarmee al te zeer in de verleiding om de grote maatschappelijke vragen maar gewoon helemaal uit de weg te gaan, de samenleving de rug toe te keren en zich te verliezen in wetenschapsintern gekissebis over data en methoden en technieken. Dit laatste lot heeft de Nederlandse sociologie de afgelopen decennia in toenemende mate getroffen, en inmiddels verlangen de meeste sociologen niet langer veel meer van elkaar dan slechts de productie van zoveel mogelijk artikelen in internationale peer-refereed tijdschriften, die zoveel mogelijk worden geciteerd door andere sociologen, maar behalve door een handvol vakgenoten elders in de wereld door vrijwel niemand worden gelezen. Wanneer deze wetenschapsinterne criteria vervolgens worden gebruikt om de wetenschappelijke pikorde vast te stellen, en dat is wat in toenemende mate gebeurt, dan heeft dat tot gevolg dat de boegbeelden van het vak in de publieke beeldvorming - collega's als Kees Schuyt, Anton Zijderveld en Jacques van Doorn zelf - het eenvoudigweg afleggen tegen de eerste de beste postdoc. Wie als jonge onderzoeker desondanks nog een carrière in de sociologie mocht ambiëren, weet dus wat hem of haar te doen staat, maar het behoeft geen betoog dat hierdoor de maatschappelijke betekenis van het vak steeds verder wordt ondergraven.

Over de vraag of dit laatste 'erg' is kan men uiteraard verschillend oordelen, maar het lijkt mij persoonlijk niet iets om de schouders over op te halen. De sociologie is immers een wezenlijk andere tak van sport dan bijvoorbeeld de medische wetenschap en dat heeft belangrijke gevolgen voor haar maatschappelijke legitimering. Voor het medische onderzoek is het nauwelijks problematisch wanneer men slechts wordt afgerekend op de productie van artikelen in internationale peer-refereed tijdschriften. Misschien zal er immers ooit een medische onderzoeksgroep in slagen om een probaat middel te vinden tegen kanker, aids of een andere nare ziekte. En of dat dan een Nederlandse onderzoeksgroep of een buitenlandse zal zijn maakt niet zoveel uit. Waar onderzoeksgroepen over de hele wereld in onderlinge competitie werken aan het oplossen van dezelfde problemen, dragen ze immers allemaal hun steentje bij - al is het maar door het aandragen van oplossingen voor kleinere 
deelproblemen of het elkaar motiveren om als eerste de echt belangrijke doorbraken te forceren.

In de sociologie speelt dit alles echter niet, om de doodeenvoudige reden dat het vak een dergelijk 'nut' ontbeert. Ik heb althans nog nooit een collega ontmoet die gelooft dat sociologen ooit het sociaal-wetenschappelijke $\mathrm{E}=\mathrm{mc}^{2}$ zullen ontdekken, waarmee oorlog, rassenwaan, hongersnood of andere oorzaken van menselijk leed kunnen worden uitgebannen. En voor zover bescheidener doelstellingen wel kunnen worden gerealiseerd via een instrumentele toepassing van sociologischtheoretische kennis, heeft juist dat type doelstellingen de neiging maatschappelijk omstreden te zijn, waardoor het vak zichzelf daarmee tot een onderdeel van het politieke spel maakt. Dat sociologiebeoefening geen strikt instrumenteel en politiek neutraal 'nut' heeft, betekent echter nog niet dat zij geen reflexieve 'zin' heeft, en precies daarom behoren sociologische inzichten naar mijn oordeel breder te worden gedeeld dan alleen met internationale vakgenoten.

Hoewel zo'n meer 'reflexieve' rol van de sociologie in Van Doorns werk een steeds prominentere plaats is gaan innemen, valt niet te verwachten dat veel jonge sociologen hem hierin nog zullen willen navolgen. De weg naar een leerstoel wordt tegenwoordig immers uitsluitend nog geplaveid door artikelen in peer-refereed internationale tijdschriften, dus wie kiest voor Nederlandstalige of populariserende publicaties, schaadt daarmee onontkoombaar de eigen academische loopbaan. Jonge sociologen worden door deze figuratie aangemoedigd de samenleving de rug toe te keren en naar mijn oordeel zou men er in sociologenkring verstandig aan doen zich eens serieus af te vragen of hierdoor op de wat langere termijn de maatschappelijke legitimiteit van dit in wezen nutteloze vak niet beslissend wordt ondergraven en of men zich dat eigenlijk wel kan veroorloven.

\section{Conclusie}

Het is wel duidelijk. Er vallen zeer verschillende verhalen te vertellen over de ontwikkeling van de Nederlandse sociologie sinds de publicatie van Moderne sociologie een halve eeuw geleden. Volgens sommigen is de Nederlandse sociologie thans beter dan zij ooit was. En afgaande op de grote vorderingen op het terrein van de statistische analysemethoden, die gepaard zijn gegaan met een radicale internationalisering van het Nederlandse sociologisch onderzoek, valt daar ook best iets voor te zeggen. Tot in de jaren tachtig publiceerden Nederlandse sociologen nog niet of nauwelijks in de twee belangrijkste Amerikaanse tijdschriften, American Sociological Review en American Journal of Sociology, maar tegenwoordig is dat niets bijzonders meer. Ook kan worden vastgesteld dat 
academische sociologen steeds meer 'grote-mensenwetenschappers' zijn geworden in plaats van de onverbeterlijke moralisten, wereldverbeteraars en politieke activisten die zij ooit waren. Maar anderen wijzen erop dat juist deze ontwikkeling de maatschappelijke betekenis van het vak steeds verder dreigt te ondergraven en dat dat nog wordt versterkt door de toegenomen nadruk op het belang van publicaties in internationale peer-refereed journals. Verschillende stemmen en verschillende verhalen, kortom, voortkomend uit radicaal verschillende opvattingen over wat de sociologie is - of beter: wat zij zou moeten zijn.

De ontwikkeling van een wetenschappelijke sociologie, waarin systematisch empirisch onderzoek en sociologische theorievorming elkaar wederzijds bevruchten, is een stuk lastiger gebleken dan Van Doorn destijds dacht. In feite is hier niet veel van terechtgekomen en is zijn intellectuele agenda van een halve eeuw terug inmiddels zelfs voor een groot deel overboord gekieperd. Het sociologisch onderzoek is hierdoor steeds verder verdwaald in een theoretisch betrekkelijk betekenisloos data- en methodenfetisjisme en de sociologieopleidingen zijn steeds meer veranderd in veredelde statistiekcursussen. De sociologen met de meeste internationale publicaties en citaties laten zich bovendien maar weinig aan de maatschappelijke betekenis van het vak gelegen liggen. Zij lijken het besteden van tijd hieraan te beschouwen als weinig meer dan een hinderlijke afleiding van waar het 'echt' om gaat - het publiceren van zoveel mogelijk internationale artikelen in tijdschriften met een zo hoog mogelijke impact factor - en lijken de prioriteitstelling van sociologen die wel columns, rapporten en artikelen voor een lekenpubliek schrijven te zien als een soort academische valsemunterij, slechts bedoeld om het eigen wetenschappelijk falen te maskeren.

De wetenschappelijke status en de maatschappelijke betekenis van het vak zijn elkaar mettertijd kortom steeds meer in de weg komen te staan en nu de wetenschap steeds meer is gaan lijken op de nationale oliebollentest van het $A D$ ('Wie schrijft de meeste artikelen voor internationale peer-refereed tijdschriften en wordt het vaakst geciteerd door collega's die dat ook doen?') is wel duidelijk wie er de komende jaren aan het kortste eind zullen gaan trekken. Men zegt dat sociologen niet kunnen voorspellen, maar laat ik dan toch maar eens een voorspellinkje wagen. Ik voorspel dat over twintig jaar de maatschappelijke betekenis van de academische sociologie vrijwel volledig zal zijn verdampt en dat vrijwel al degenen die zich hier thans nog hard voor menen te moeten maken de universiteiten zullen hebben verlaten - vrijwillig, en dus uit eigen onvrede, dan wel gedwongen, vanwege achterblijvende wetenschappelijke prestaties (opgevat als artikelen in SSCI-tijdschriften en SSCI-citaties). Natuurlijk zullen er tegen die tijd nog steeds volop sociologen zijn die de maatschappelijke betekenis van het vak hoog houden, maar zij zullen 
nog meer dan thans buiten de universiteiten werkzaam zijn (vergelijk Pels elders in dit boek).

En dan ten slotte, om het netjes af te ronden, ook nog maar een voorspelling over degenen die tegen die tijd nog wel de afdelingen sociologie van de Nederlandse universiteiten bevolken. Wat doen die daar dan? Zij zullen, de lezer had het vast al geraden, artikelen schrijven voor internationale peer-refereed tijdschriften - artikelen over de effecten van variabelen op andere variabelen. En die effecten zullen tegen die tijd bovendien worden vastgesteld met aanzienlijk verbeterde statistische methoden, want de wetenschappelijke vooruitgang valt natuurlijk niet te stoppen.

Maar als onverbeterlijke optimist - sommige mensen leren het nooit - wil ik graag besluiten met het goede nieuws. Dat is, ik suggereerde het zojuist al, dat sociologen helemaal niet kunnen voorspellen. Dat komt doordat mensen niet simpelweg slachtoffers van blinde krachten en systemen zijn. Mensen hebben, uitzonderlijke omstandigheden daargelaten, vrijwel altijd de mogelijkheid om nee te zeggen, de kont eens lekker tegen de krib te gooien en gewoon iets heel anders te gaan doen dan wat systemen en mannen in zwarte pakken van hen verlangen. En dat geldt dus ook voor de sociologen, die iedere dag opnieuw beslissingen nemen waarmee zij vormgeven aan de toekomst van hun vak. Misschien is het goed wanneer zij zich dat wat meer gaan realiseren.

\section{Noot}

1. Een ingekorte versie van dit hoofdstuk verscheen eerder in het tijdschrift Sociologie (Houtman 2009).

\section{Geraadpleegde literatuur}

Achterberg, P., D. Houtman, S. Aupers, W. de Koster, P. Mascini en J. van der Waal (2009), 'A Christian Cancellation of the Secularist Truce? Waning Christian Religiosity and Waxing Religious Deprivatization in the West', Journal for the Scientific Study of Religion 48: 687-701.

Alexander, J.C. (1982), Theoretical Logic in Sociology (Volume 1). Positivism, Presuppositions, and Current Controversies, Berkeley: University of California Press.

Bauman, Z. (1987), Legislators and Interpreters. On Modernity, Post Modernity, and Intellectuals, Oxford: Polity Press.

Bauman, Z. (1992), Intimations of Postmodernity, Londen: Routledge.

Becker, H.S. (1967), 'Whose Side Are We On?', Social Problems 14: 239-248.

Black, D. (2000), 'Dreams of Pure Sociology', Sociological Theory 18: 343368.

Doorn, J.A.A. van (1953a), 'Ten geleide’, Sociologische gids 1: 1-2. 
Doorn, J.A.A. van (1953b), 'Boekbespreking', Sociologische gids 1: 132-134.

Doorn, J.A.A. van (1964), Beeld en betekenis van de Nederlandse sociologie, Utrecht: Bijleveld.

Doorn, J.A.A. van (1987), Relativering van rationaliteit. Over de grenzen van technisch denken en technocratische beheersing, 's-Gravenhage: VUGA.

Doorn, J.A.A. van (1988), Rede en macht. Een inleiding tot beleidswetenschappelijk inzicht, 's-Gravenhage: VUGA.

Doorn, J.A.A. van (1996), De draagbare Van Doorn, Amsterdam: Prometheus.

Doorn, J.A.A. van (2000), 'Sociale wetenschappen en de weerbarstige werkelijkheid', in: P.B. Lehning (red.), De beleidsagenda 2ooo. Strijdpunten op het breukvlak van twee eeuwen, Bussum: Coutinho, p. 24-41.

Doorn, J.A.A. van en C.J. Lammers (1959), Moderne sociologie. Systematiek en analyse, Utrecht: Het Spectrum (Aula).

Duyvendak, J.W. (2004), Een eensgezinde, vooruitstrevende natie. Over de mythe van 'de' individualisering en de toekomst van de sociologie, Amsterdam: Vossiuspers.

Eisinga, R.N. en P.L.H. Scheepers (1989), Etnocentrisme in Nederland. Theoretische en empirische verkenningen, Nijmegen: ITS.

Elchardus, M. en J. Siongers, (2009), Vreemden. Naar een cultuursociologische benadering van etnocentrisme, Brussel: Lannoo.

Gouldner, A.W. (1962), 'Anti-Minotaur. The Myth of a Value-Free Sociology', Social Problems 9: 199-213.

Gouldner, A.W. (1970), The Coming Crisis of Western Sociology, Londen: Heinemann.

Horowitz, I.L. (1993), The Decomposition of Sociology, New York: Oxford University Press.

Houtman, D. (1994), Werkloosheid en sociale rechtvaardigheid. Oordelen over de rechten en plichten van werklozen, Amsterdam: Boom.

Houtman, D. (200o), Een blinde vlek voor cultuur. Sociologen over cultureel conservatisme, klassen en moderniteit, Assen: Van Gorcum.

Houtman, D. (2002), 'Subjectivering, neo-gnosticisme en postmodern relativisme. Anton Zijderveld en de analyse van de moderne cultuur', in: H. van de Braak en T. Bevers (red.), De waarde van instituties. Essays voor Anton Zijderveld, Amsterdam: Amsterdam University Press, p. 140164.

Houtman, D. (2003a), 'Lipset and 'Working-Class' Authoritarianism', American Sociologist 34: 86-105.

Houtman, D. (2003b), Class and Politics in Contemporary Social Science. 'Marxism Lite' and Its Blind Spot for Culture, New York: Aldine de Gruyter.

Houtman, D. (2003c), 'De onttovering van de wereld en de crisis van de sociologie. Hoe de sociologen van God's schoot zijn getuimeld', in: D. Houtman, B. Steijn en J. van Male (red.), Cultuur telt: Sociologische opstellen voor Leo d'Anjou, Maastricht: Shaker, p. 35-57. 
Houtman, D. (2006), 'Op de ruïnes van de traditie. Individualisering, culturele verandering en de toekomst van de sociologie', in: G. Engbersen en J. de Haan (red.), Balans en toekomst van de sociologie, Amsterdam: Amsterdam University Press, p. 211-223.

Houtman, D. (2008a), 'God in Nederland 1996-2006. Enkele godsdienstsociologische routines ter discussie, Religie en samenleving 3: 17-35.

Houtman, D. (2008b), Op jacht naar de echte werkelijkheid. Dromen over authenticiteit in een wereld zonder fundamenten, Amsterdam: Pallas.

Houtman, D. (2009), 'Een halve eeuw na Moderne sociologie (1959). J.A.A. van Doorn is dood en de sociologie voelt zich niet zo lekker', Sociologie 5: 521-539.

Houtman, D. en P. Achterberg (2009), 'Arbeiders en schoolmeesters. Een huwelijk in crisis', Socialisme en Democratie 66: 22-27.

Houtman, D. en P. Mascini (2002), 'Why Do Churches Become Empty, While New Age Grows? Secularization and Religious Change in the Netherlands', Journal for the Scientific Study of Religion 41: 455-473.

Inglehart, R. (1977), The Silent Revolution. Changing Values and Political Styles among Western Publics, Princeton, NJ: Princeton University Press.

Kohn, M.L. (1977 [1969]), Class and Conformity. A Study in Values (Second Edition), Chicago: University of Chicago Press.

Kohn, M.L. en K.M. Slomczynski (1990), Social Structure and Self-Direction. A Comparative Analysis of the United States and Poland, Oxford: Basil Blackwell.

Lemert, C. (1995), Sociology After the Crisis, Boulder, CO: Westview Press.

Lepenies, W. (1988), Between Literature and Science. The Rise of Sociology, Cambridge: Cambridge University Press.

Lipset, S.M. (1981), Political Man. The Social Bases of Politics (Expanded Edition), Baltimore, MD: Johns Hopkins University Press.

List, G. van der (1996), 'Inleiding', in: J.A.A. van Doorn, De draagbare van Doorn, Amsterdam: Prometheus, p. 7-21.

Lopreato, J. en T.A. Crippen (1999), Crisis in Sociology. The Need for Darwin, New Brunswick, NJ: Transaction.

Lyotard, J.-F. (1984 [1979]), The Postmodern Condition. A Report on Knowledge, Manchester: Manchester University Press.

Merton, R.K. (1968), Social Theory and Social Structure (Enlarged Edition), New York: Free Press.

Mills, C.W. (1959), The Sociological Imagination, New York: Oxford University Press.

Mills, C.W. (1963 [1943]), 'The Professional Ideology of the Social Pathologists', in: I.L. Horowitz (red.), Power, Politics, and People. The Collected Essays of C. Wright Mills, New York: Balantine, p. 525-552.

Nijhof, G. (2008), 'Afstandelijkheid in Nederlands sociologisch onderzoek', Sociologie 4(4): 419-436. 
Oakes, G. (1975), 'Introductory Essay', in: M. Weber, Roscher and Knies. The Logical Problems of Historical Economics, New York: Free Press, p.1-49.

Roszak, T. (1969), The Making of a Counter Culture. Reflections on the Technocratic Society and Its Youthful Opposition, New York: Doubleday.

Seidman, S. (1994), Contested Knowledge. Social Theory in the Postmodern Era, Cambridge, MA: Blackwell.

Sniderman, P.M., L. Hagendoorn en M. Prior (2004), 'Predisposing Factors and Situational Triggers. Exclusionary Reactions to Immigrant Minorities', American Political Science Review 98: 35-49.

Spector, M. en J.I. Kitsuse (1977), Constructing Social Problems, Menlo Park, CA: Cummins.

Toulmin, S. (1990), Cosmopolis. The Hidden Agenda of Modernity, Chicago: University of Chicago Press.

Tubergen, F. van (2008), 'Vooruitgang in de sociologie. Regulatieve ideeen en methoden van onderzoek', Sociologie 4: 437-440.

Turner, J. (1992), 'The Promise of Positivism', in: S. Seidman en D.G. Wagner (red.), Postmodernism and Social Theory. The Debate over General Theory, Cambridge, MA: Blackwell, p. 156-178.

Veen, R. van der (2008), 'Tussen rede en macht. Naar een reflexieve beleidssociologie', Sociologie 4: 412-418.

Waal, J. van der, P. Achterberg en D. Houtman (2007), 'Class Is Not Dead It Has Been Buried Alive. Class Voting and Cultural Voting in Postwar Western Societies (1956-1990)', Politics and Society 35: 403-426.

Weber, M. (1978 [1904-1905]), The Protestant Ethic and the Spirit of Capitalism, Londen: Allen \& Unwin.

Weber, M. (1972 [1920-1921]), Wirtschaft und Gesellschaft. Grundriß der Verstehenden Soziologie, Tübingen: Mohr.

Weber, M. (1951 [1922]), Gesammelte Aufsätze zur Wissenschaftslehre, Tübingen: Mohr.

Zijderveld, A.C. (1970), The Abstract Society. A Cultural Analysis of Our Time, New York: Doubleday. 


\title{
II Slotbeschouwing
}

\section{Van Doorn en de toekomst van de sociologie}

\author{
Jacques van Hoof, Dick Houtman, Peter Mascini, \\ René Moelker en Sjo Soeters
}

De sociale wetenschappen hebben de taak ook voor het heden en de toekomst nieuwe ideeën, interpretaties en beelden te produceren. L'imagination au pouvoir is hun blijvende opdracht. Dat ze op die manier veel complexiteit vereenvoudigen, is eerder een zegen dan een zonde; ze maken dusdoende de maatschappelijke werkelijkheid voor mensen draaglijk. J.A.A. van Doorn 2000: 41

\section{Inleiding}

Doel van de studiedag die de NSV in 2009 over de betekenis van Van Doorn voor de Nederlandse sociologie organiseerde was niet alleen om de historische rol van Van Doorn in de naoorlogse sociologie te belichten. Het was ook te doen om de actuele betekenis van zijn ideeën en de relevantie van zijn opvattingen en manier van sociologie bedrijven voor de toekomst van de sociologie. In deze slotbeschouwing zullen we vooral daarbij stilstaan. Wat heeft Van Doorn nieuwe generaties sociologen te zeggen?

Dat is geen overbodige exercitie. Voor veel jongere sociologen is Van Doorn niet meer dan een naam uit het verleden van de vaderlandse sociologie, op zijn best een man die zij voornamelijk als columnist kennen. Dat zegt veel over de toestand waar de sociologieopleidingen tegenwoordig in verkeren. Door de studieduurverkorting en de komst van de BAMA structuur heeft zich een rationaliseringsproces voltrokken dat weinig plaats meer laat voor een kennismaking met de geschiedenis van de sociologie, laat staan die van de Nederlandse sociologie. Was voor vroegere generaties de breed georiënteerde en erudiete algemeen socioloog à la Van Doorn een rolmodel, voor de huidige generatie lijkt dit eer- 
der de in internationale toptijdschriften publicerende gespecialiseerde onderzoeker te zijn.

Maar we kunnen er ook niet omheen dat Van Doorn zelf zich in zijn latere jaren vaak nogal sceptisch over de ontwikkeling van de sociologie heeft uitgelaten en soms zelfs de relevantie van de sociologie in de veranderende maatschappelijke omstandigheden van de late twintigste eeuw in twijfel leek te trekken. En dat hij in lijn daarmee zich in zijn eigen wetenschappelijke werk steeds meer op historische onderwerpen richtte. Daarom beginnen we deze slotbeschouwing met een bespreking van zijn opvattingen over de ontwikkeling en de toekomstperspectieven van de sociale wetenschappen in het algemeen en die van de sociologie in het bijzonder, zoals hij die in het jaar 2000 nog eenmaal verwoord heeft in een publicatie, waaruit ook het bovenstaande citaat afkomstig is (Van Doorn 200o). Daarna zullen we op basis van de bijdragen in deze bundel verschillende aspecten van Van Doorns sociologische erfenis bespreken.

\section{Van Doorn over de opkomst en neergang van de sociale wetenschappen}

In de genoemde publicatie, die de titel 'Sociale wetenschappen en de weerbarstige werkelijkheid' draagt, probeert Van Doorn een verklaring te geven voor het feit dat de sociale wetenschappen na een spectaculaire opkomst in de jaren onmiddellijk na de Tweede Wereldoorlog vanaf de jaren zeventig een bijna even opmerkelijke neergang hebben doorgemaakt. De ontwikkeling van de sociologie neemt daarbij een centrale plaats in. Hij zoekt die verklaring niet alleen in ontwikkelingen binnen de sociale wetenschappen zelf, maar ook en vooral in het spanningsveld tussen wetenschap, maatschappij en beleid. Wat het eerste betreft wijst hij op de sociologisering van de wetenschapsleer die door Thomas Kuhn op gang is gebracht en die een einde gemaakt heeft aan de consensus over het (neo)positivistische wetenschapsprogramma dat aan de 'moderne sociologie' ten grondslag lag en medeverantwoordelijk was voor haar groeiende aanzien bij andere disciplines zoals de geschiedenis en de culturele antropologie. Niet alleen leidde dit tot een nieuwe methodestrijd binnen de sociale wetenschappen, maar het maakte ook de weg vrij voor de opkomst van het 'narrativisme', waarbij de nadruk op 'het algemene, het abstracte en het collectieve' verschuift naar 'het unieke, het abstracte en het individuele' (Van Doorn 2000: 30). Daardoor werd de positie van de geschiedenis en de culturele antropologie ten opzichte van de sociale wetenschappen weer versterkt.

Maar daarbij is het niet gebleven. De maatschappelijke veranderingen in het laatste kwart van de twintigste eeuw roepen volgens Van Doorn in 
toenemende mate twijfel op aan de relevantie van de sociologie, althans de sociologie zoals die tot nu toe vorm heeft gekregen. Thema's en theorieën waarmee de sociologie groot geworden is blijken voor een groot deel aan een bepaalde historische ontwikkelingsfase gebonden. Ontwikkelingen als de groeiende fragmentatie van het sociale leven als gevolg van het losser worden van institutionele banden en een toenemende individualisering; de toenemende wisselvalligheid van het gedrag en 'de onmiskenbare subjectiveringstendentie in het sociale verkeer' (idem: 35) roepen zelfs de vraag op of de sociale wetenschappen nog wel met deze veranderende werkelijkheid en de daarmee verbonden nieuwe problemen uit de voeten kunnen.

Ook in de beleidssfeer zijn de verwachtingen over de rol van de sociale wetenschappen aanzienlijk getemperd. Het maakbaarheidgeloof dat lang de toepassing van sociaal-wetenschappelijke inzichten heeft aangejaagd is door de erosie van de grote ideologieën en het verlies aan 'stootkracht' van de dragende politieke instituties in het ongerede geraakt (idem: 36). In het zo gegroeide beleidsklimaat van muddling through lijken alleen 'beweeglijke, dicht bij het concrete gebeuren staande deeldisciplines, bereid om hun gegevens en noties overal vandaan te betrekken' (idem: 38) zich te kunnen handhaven.

Dit is inderdaad een ontnuchterende, zeg maar gewoon sombere analyse. Maar het is opmerkelijk dat Van Doorn hieruit niet de conclusie trekt dat het einde van de sociologie nabij is. Zijn stuk eindigt met 'enkele lessen voor de toekomst'. De sociologie zou zich niet in de armen van het narrativisme en postmodernisme moeten storten, maar zal (zo zegt hij het Zygmunt Bauman na) wel een sociologie van het postmodernisme moeten ontwikkelen, dat wil zeggen de postmoderne trekken van de huidige samenleving tot voorwerp van studie moeten maken. De sociologie zal daarom op zoek moeten gaan naar 'nieuwe interpretaties' die recht doen aan 'het inzicht dat de huidige maatschappij op fundamentele punten verschilt van die van gisteren'. Er zal ook gewerkt moeten worden aan de hersociologisering (sic) van de geschiedenis en de culturele antropologie 'voor zover deze wetenschappen zich te zeer door het narrativisme op sleeptouw hebben laten nemen' (idem: 39).

De beleidsgerichte socioloog zal een middenweg moeten zien te vinden tussen 'de vaak wel erg concrete benadering van het beleidsonderzoek' en de verleiding om een zo hoog mogelijk abstractieniveau te kiezen. Daarbij zal hij/zij meer dan vroeger 'de ervaringswijsheid van de gemiddelde burger' serieus moeten nemen. En ten slotte zal men er voor moeten waken het maakbaarheidperspectief te sterk te accentueren. 'De sociale en culturele wetenschappen hebben nog een andere opdracht meegekregen, namelijk zingeving en betekenisverlening' (idem: 41). Het blijft ook voor de toekomst hun taak 'de problematiek van de eigen tijd 
te interpreteren op een manier die nieuwe kennis schept en de mogelijkheid tot maatschappelijke interventie verheldert' (idem: 25).

Van Doorn heeft de sociologie dus niet afgeschreven om zich vervolgens tot de geschiedenis te bekennen. Alle inleiders op de studiedag gingen ervan uit dat Van Doorn socioloog is gebleven en ook in zijn historische studies, zoals zijn boek over het koloniale project in Indië, vanuit een sociologisch perspectief is blijven werken. Volgens de historicus Blussé is hij juist daardoor voor historici interessant. Het bovenstaande is eerder te lezen als een oproep om de sociological imagination verder te ontwikkelen en te gebruiken om de fundamentele veranderingen in de huidige samenleving te doordenken. Ze vormen tegelijkertijd een pleidooi voor wat Van der Veen in deze bundel een reflexieve beleidssociologie noemt. Met dat programma kunnen sociologen wel weer even verder.

Toch is het goed om bij de argumenten die Van Doorn gebruikt stil te staan. Centraal daarin staat de oprukkende individualisering die volgens Van Doorn tot uiting komt in sterk fluctuerend gedrag en daarmee de basis voor sociologische verklaringen ondergraaft. Die redenering wordt door de sociologen die in deze bundel aan het woord zijn geweest niet gedeeld. Houtman betoogt dat individualisering tot nieuwe waarden en normen heeft geleid rondom de alom gedeelde overtuiging dat individuele keuzevrijheid het hoogste goed is. Pels spreekt in dit verband over 'de nieuwe kuddementaliteit van consumenten die allemaal denken dat ze uniek, authentiek, eigen en apart (moeten) zijn' en over de 'paradox van het geïnstitutionaliseerde individualisme', waarvoor Van Doorn weinig oog had. Het is juist een cultuursociologie nieuwe stijl die volgens Houtman thans regelmatigheden in het sociale leven kan blootleggen.

Ook de gevolgen van het proces van individualisering (zoals de doorwerking ervan op de meritocratisering van de samenleving) lenen zich goed voor sociologische analyse en vragen om 'nieuwe interpretaties' (we komen daar verderop nog op terug). Dan komen we uit bij andere sociologische kernthema's die minder gevoelig zijn voor sociale fragmentatie en toenemende wisselvalligheid van het sociale gedrag (zie ook de bijdrage van Ultee). Zo'n thema is bijvoorbeeld sociale ongelijkheid. Daarbij gaat het in eerste instantie om de structurering en verdeling van levenskansen die het lot van individuen ook in een meer meritocratische samenleving in belangrijke mate blijven beïnvloeden, zoals het moderne stratificatieonderzoek laat zien. Ook rationalisering is altijd een centraal thema van de sociologie geweest. Als er één thema is dat als een rode draad door het werk van Van Doorn loopt, zo betoogt Van der Veen in deze bundel, dan is het wel de fascinatie voor de maatschappelijke functies en disfuncties van de rationele, construerende, organiserende en beleidsmatige kant van de moderne samenleving. En ook dit proces blijft voor en achter de schermen van een geïndividualiseerde samen- 
leving actief, hoewel het wellicht meer op weerstanden stuit dan vroeger en de uitkomsten ervan dus (nog) minder voorspelbaar zijn. Genoeg mogelijkheden voor een toekomstgerichte sociologie dus en genoeg uitdagingen om 'nieuwe interpretaties' te ontwikkelen.

Vanuit dit vertrouwen in de blijvende relevantie van een sociologische benadering voor de sociale werkelijkheid van de eenentwintigste eeuw (hoe weerbarstig deze ongetwijfeld zal zijn) nemen wij nu de sociologische erfenis van Van Doorn onder de loep. We beginnen algemeen met een analyse van Van Doorns programma voor de sociologie als wetenschap en zijn sociologische perspectief en eindigen concreet met zijn betekenis voor bepaalde deelgebieden van de sociologie en zijn diagnose van de actuele sociaal-politieke ontwikkelingen. Al deze vier aspecten zijn op de studiedag aan de orde geweest.

\section{De sociologische erfenis van Van Doorn}

\section{Van Doorns methodologische programma voor de sociologie}

Houtman heeft in zijn bijdrage laten zien dat in Van Doorns vroege kritiek op het empiricisme van de sociografische traditie en de brede, niet toetsbare en moralistische generalisaties van de toenmalige cultuursociologie een programma voor de sociologie ligt opgesloten dat nog onverminderd actueel is: de ontwikkeling van een wetenschappelijke sociologie waarin systematisch empirisch onderzoek en sociologische theorievorming elkaar wederzijds bevruchten. Inspiratiebron was daarbij onder meer Mertons pleidooi voor theories of the middle range als een brug tussen empirische generalisaties en brede, maar inhoudsloze theoretische perspectieven.

Op het eerste gezicht lijken de meeste Nederlandse sociologen zich dat ter harte te hebben genomen. Nadat een nieuwe aanval van grand theory (nu in marxistische gedaante) is afgeslagen, is een proces van verwetenschappelijking op gang gekomen dat met name in het sociologische onderzoek zichtbaar wordt. Weinig sociologen zullen zich nog wagen aan uitspraken die niet empirisch onderbouwd kunnen worden en de meeste onderzoekers zullen zich houden aan de in elk methodologieboek verkondigde wijsheid dat onderzoek begint met het formuleren van hypotheses. Het onderzoek zelf krijgt steeds meer een kwantitatief karakter, waarbij steeds verfijndere statistische technieken worden gebruikt. En er wordt steeds meer over gepubliceerd, ook (of misschien wel juist) in internationale wetenschappelijke tijdschriften.

Toch is het maar de vraag of al dat onderzoek nu zoveel bijdraagt aan systematische theorievorming. Houtman is daar erg sceptisch over, sociologen nemen volgens hem te vaak genoegen met het met veel sta- 
tistisch vernuft vaststellen van relaties tussen variabelen zonder zich af te vragen wat dat betekent voor de houdbaarheid van theorieën. Volgens hem heeft dat mede te maken met een te grote schroom van veel sociologen om uitspraken te doen die niet volledig empirisch gedekt zijn, maar ook met de publicatiedruk en de criteria die door redacties van internationale tijdschriften worden aangehouden. Daar zal niet iedereen het mee eens zijn. Maar zelfs degenen die daar positiever over denken zullen moeten toegeven dat het gevaar om louter in empirische generalisaties te blijven steken nog steeds levensgroot aanwezig is. Daarom vormt Van Doorns programma nog steeds een uitdaging voor de huidige sociologen.

In dit verband rijst wel de vraag in hoeverre Van Doorn zich zelf aan dit programma gehouden heeft. In elk geval heeft hij weinig aan de verzameling van primaire data gedaan (zie onder andere de bijdragen van Ellemers en Ultee). Maar daar is minstens één belangrijke en nog steeds relevante uitzondering op: de geweldsexcessen tijdens de politionele acties in Indonesië. Van een systematische toetsing van theorieën is ook maar weinig sprake. Blussé noemt een voorbeeld daarvan in het boek $D e$ laatste eeuw van Indië (Van Doorn 1994), waarin drie theorieën over economische ontwikkeling worden gebruikt om het tot stand komen van een markteconomie in een landstreek op Java (de Preanger, bekend om zijn theecultuur) te verklaren. Maar in het algemeen was dat niet zijn stijl van sociologiebeoefening. Ultee stelt in een kritisch getoonzet stuk dat Van Doorn niet zo heel veel heeft bijgedragen aan systematische theorievorming. Daarbij richt hij zijn pijlen vooral op het functionalistische perspectief dat Van Doorn in de eerste helft van zijn loopbaan veelvuldig hanteerde en dat volgens Ultee arm aan toetsbare uitspraken blijft. Hij brengt dat ook in verband met het soort vragen dat Van Doorn zich stelde: vanwege een te geringe aandacht voor beschrijvingsvragen zijn verklaringsvragen vaak niet scherp genoeg uitgewerkt. Ellemers concludeert dat Van Doorn vooral een ideeënman was die vaak met flitsende ideeën en aansprekende voorbeelden in staat was sociale verschijnselen op een verrassende manier te belichten. Maar hij stelt ook vast dat hij daarbij eclectisch te werk ging, dat de ideeën vaak schetsmatig werden uitgewerkt en in de loop van de tijd ook nog weleens werden aangepast.

Misschien moeten we concluderen dat Van Doorn zich in zijn eigen werkzaamheden steeds meer op een specifiek onderdeel van het genoemde programma heeft gericht, dat in de kern geformuleerd is in het motto dat wij voor deze slotbeschouwing gekozen hebben: het bieden van interpretaties waarmee nieuw licht op sociale verschijnselen geworpen kan worden om op die manier nieuwe kennis te genereren. Interpretaties die hij voornamelijk ontleende aan zijn brede kennis van de sociologische, historische en politicologische literatuur. Een aanpak die overigens ook 
al in zijn vroegste publicaties over actuele onderwerpen, zoals de wijkgedachte en de verzuiling (beide herdrukt in zijn laatste bundel Nederlandse democratie) terug te vinden is. Waarbij wij aantekenen dat het aanbieden van nieuwe interpretaties slechts een eerste stap is in de richting van de ontwikkeling van nieuwe kennis. Van Doorn zou dat overigens volmondig erkennen: hij presenteerde veel van zijn ideeën als voorlopig, eerste verkenning, et cetera, zoals Ellemers opmerkt. Aan nieuwe generaties sociologen de taak om de vaak prikkelende interpretaties die Van Doorn ook in zijn latere jaren bleef aanbieden systematischer uit te werken en te toetsen.

\section{Het sociologische perspectief}

Voor de oudere generaties sociologen is Van Doorns sociologische perspectief in eerste instantie het functionalisme zoals dat te vinden is in Moderne sociologie. Systematiek en analyse (1959). In zijn bijdrage in deze bundel benadrukt co-auteur Lammers (die soms de credits gekregen heeft voor de systematische benadering die in het boek uiteengezet wordt) dat het boek (en ook de revisie ervan in 1974) een echte co-productie was waarin Van Doorn een groot aandeel gehad heeft. Hoewel Van Doorn volgens eigen zeggen de benadering nooit in zijn geheel heeft toegepast, is het niet moeilijk om in Van Doorns werk functionalistische begrippen en redeneringen te vinden.

Een goede illustratie vormt Van Doorns bijdrage aan de militaire sociologie, die in deze bundel door Moelker is besproken. Van Doorn was van 1962 tot 1972 hoogleraar aan de KMA, de periode dus dat hij zich het meest als 'moderne socioloog' heeft doen kennen. Hij heeft over vele 'militaire' onderwerpen zijn licht laten schijnen, naast de militaire organisatiemethoden en het geweldsgebruik en -misbruik ook over vermaatschappelijking en legitimiteitscrisis van het leger, de overgang van massa- naar vrijwilligerslegers, de rol van het internaat voor persoonsvorming en socialisatie. Daaraan ligt vaak het voor oude en nieuwe systeemtheoretici heel herkenbare beeld ten grondslag van de militaire organisatie als een tamelijk opzichzelfstaand deelsysteem dat onder druk komt te staan door veranderingen in de samenleving. De wijze waarop de organisatie zich daaraan probeert aan te passen en de spanningen en tegenstrijdigheden die zich daarbij voordoen vormen een centraal aandachtspunt. En het is hier bepaald geen 'uitspraakarm' systeemfunctionalisme (vergelijk de kritiek van Ultee), getuige de hypotheses die in dat kader werden geformuleerd en die andere sociologen (ook in het buitenland) tot onderzoek geïnspireerd hebben.

Maar we kunnen niet met het begrip functionalisme volstaan om Van Doorns sociologische perspectief te karakteriseren. Bij lezing van 
de vroegste bijdragen die in de bundel Nederlandse democratie te vinden zijn (naast die over de wijkgedachte ook de kritiek op het begrip proletarische achterhoede van de cultuursocioloog Haveman) valt op dat Van Doorns analyses van meet af aan zijn ingebed in een visie op langetermijnveranderingen van de samenleving, op modernisering dus. Zo kreeg Haveman anno 1954 niet alleen de wind van voren omdat zijn stelling dat er een welomlijnde proletarische achterhoede met een eigen subcultuur zou bestaan empirisch onhoudbaar was, maar ook omdat hij geen rekening hield met processen als emancipatie en verburgerlijking en dus een te statisch en te weinig gedifferentieerd beeld van de proletarische achterhoede gaf (Van Doorn 2009: 79-89).

In zijn visie op modernisering staat allereerst het proces van rationalisering in combinatie met het streven naar beheersing centraal. Rede en macht dus, niet voor niets de titel van het boek dat misschien wel als Van Doorns hoofdwerk kan worden beschouwd. In onze bundel wordt dat met name door de socioloog Van der Veen naar voren gebracht. De politicoloog De Beus en de historicus De Rooy komen in hun inleiding bij Nederlandse democratie tot dezelfde conclusie. Dat impliceert behalve een niet-aflatende aandacht voor het organisatiefenomeen ook een grote nadruk op de rol van elites en van leiderschap, de politieke dimensie van modernisering dus en op de mogelijkheden en grenzen van overheidsinterventies (waarvoor Van Doorn vaak de term 'projecten' gebruikt). De genoemde auteurs laten ook zien dat Van Doorn mettertijd steeds sceptischer werd over de gevolgen van rationalisering en de effecten van het streven naar beheersing. De disfuncties zijn geleidelijk het beeld gaan overheersen.

Er valt volgens ons veel voor te zeggen om hier het begrip individualisering als een tweede kernelement van zijn visie op modernisering toe te voegen. In elk geval speelt het in zijn latere werk een grote rol, zoals we eerder gezien hebben. Zijn kijk op de huidige samenleving wordt er sterk door gekleurd. Maar ook in zijn vroegste beschouwingen is het al terug te vinden, neem bijvoorbeeld de eerdergenoemde kritiek op de wijkgedachte uit 1955, die voor een groot deel gebaseerd is op de stelling dat sociale relaties veranderen in een meer geïndividualiseerde en functionele richting waardoor nieuwe stadswijken als integratiekader maar een beperkte betekenis hebben (Van Doorn 2009: 90-116). Van Doorn heeft beide pijlers van het moderniseringsproces ook op elkaar betrokken. Zo is zijn groeiende scepsis over de werkzaamheid van beleid voor een groot deel voortgekomen uit zijn inschatting van de gevolgen van individualisering voor de effectiviteit en legitimiteit van het beleid en voor de slagkracht van de instituties die het beleid moeten maken en uitvoeren (zie Van Doorn 2000).

Met deze sociologische visie op modernisering, waarin rationalise- 
ring en beheersing verbonden zijn en rationalisering en individualisering in een spanningsvolle relatie staan, staat Van Doorn in een lange sociologische traditie. Daarbij dringen zich in eerste instantie de namen van Weber en De Tocqueville op, die beiden, zoals bekend, ook nogal ambivalent stonden tegenover rationalisering en individualisering. Maar dit niet alleen. Hij staat hiermee ook midden in de actuele sociologische discussie over modernisering die de laatste jaren met name door theorieën over de komst van een 'postmoderne' samenleving is aangewakkerd. Zo blijkt hij, als we mogen afgaan op verwijzingen, zich verwant te voelen met Zygmunt Bauman, een auteur die eveneens het meer fluïde worden van sociale verbanden benadrukt (liquid modernity) en die ook steeds het proces van rationalisering met het streven naar beheersing in verband gebracht heeft (en de rol van sociale wetenschappers daarbij heeft bekritiseerd). Verwantschap lijkt er ook te bestaan met sommige ideeën van sociologen als Giddens en Beck bij wie individualiseringsprocessen en daarmee verbonden identiteitsproblemen een belangrijk bestanddeel vormen van wat zij 'reflexieve modernisering' noemen, hoewel hun visie heel wat optimistischer is dan die van Van Doorn. Hij is niet de enige socioloog wiens visie op modernisering in de loop der tijd somberder is geworden, dat hoeven we ook niet per se als een teken van conservatisme (in de zin van politieke behoudzucht) te zien.

Kortom: Van Doorns sociologische perspectief valt niet alleen te karakteriseren als functionalistisch met aandacht voor de aanpassing van organisaties aan veranderende omgevingen en functies en disfuncties van verschijnselen, maar ook als een visie op sociale verandering waarin de spanningsvolle verhouding tussen rationalisering en individualisering centraal staat.

\section{Deelgebieden van de sociologie}

We gaan hier in op Van Doorns bijdrage aan de beleidssociologie en de militaire sociologie, die tijdens de studiedag ruime aandacht hebben gekregen. Er zijn natuurlijk meer deelgebieden te noemen waaraan Van Doorn belangrijke bijdragen heeft geleverd, denk aan de sociologie van de verzorgingsstaat (zie daarvoor de bijdrage van Van der Veen) en de organisatiesociologie (organisaties en organiseren vormen al vanaf Van Doorns proefschrift uit 1956 een steeds terugkerend thema). Het gaat ons hier echter niet om volledigheid, maar om concrete voorbeelden van Van Doorns sociologische erfenis.

De beleidssociologie zou je vanuit het gezichtspunt van Van Doorn eigenlijk geen apart deelgebied mogen noemen: beleid neemt in zijn sociologisch perspectief een centrale, bijna programmatische plaats in. Zo was het programma van de moderne sociologie van meet af aan nauw 
verbonden met de claim dat de via de wisselwerking tussen sociologische theorievorming en empirisch onderzoek opgebouwde wetenschappelijke kennis bruikbaar was voor en gebruikt zou moeten worden bij de oplossing van beleidsvraagstukken. Van Doorn heeft met name door de vormgeving van de Rotterdamse opleiding ook het nodige gedaan om de ontwikkeling van zo'n praktische beleidssociologie te stimuleren. Toch is hij zelf volgens Van der Veen in deze bundel nooit een echte instrumentele beleidssocioloog geweest: zijn eigen werk richtte zich vooral op de sociologie van het beleid, zoals bijvoorbeeld uit zijn vooruitziende bijdrage aan het debat over de verzorgingsstaat blijkt. In de loop der tijd is hij steeds meer de grenzen van het doelrationele streven naar beheersing en de daarmee verbonden onbedoelde en ongewenste gevolgen van beleid gaan benadrukken. Ook iets waarmee hij in de internationale discussie bepaald niet alleen staat.

De voornaamste les die we uit Van Doorns beleidssociologische studies kunnen trekken is dan ook, aldus Van der Veen, de beperktheid van het rationele model van beleidswetenschap. Daarmee wordt de weg geopend naar een reflexieve beleidssociologie, die een meerwaarde heeft boven de postmoderne variant, het vertellen van verhalen (zie Van Doorns afwijzing van het narrativisme hierboven) en de bestuurskundige variant waarbij de socioloog meelift met de beleidsmaker. Daarbij staat centraal dat beleid mensenwerk is en dat de werking ervan afhankelijk is van de mee- en tegenwerking van allerlei maatschappelijke actoren die vanuit hun eigen doelen en opvattingen op het beleid inspelen. En ook dat het vaststellen van beleidsdoelen vaak een trade-off van verschillende beleidsconcepten met zich meebrengt en dat doelen bij de uitvoering van het beleid onderworpen zijn aan een voortdurend proces van interpretatie en herdefiniëring. Volgens Van Doorn zou de beleidswetenschap zich dan ook niet zozeer moeten richten op het formuleren van eenduidige en uniformerende voorschriften, maar juist variatie en concurrentie moeten bevorderen. Een reflexieve beleidssociologie kan dus beleidsleren stimuleren zonder zich als vertegenwoordiger van de 'wetgevende rede' te manifesteren. Het belang van dit stuk van Van Doorns sociologische erfenis voor de toekomst van de sociologie kan moeilijk onderschat worden.

De militaire sociologie van Van Doorn is met uitzondering van het onderzoek naar de militaire excessen van het Nederlandse leger tijdens de Indonesische onafhankelijkheidsstrijd bij de Nederlandse sociologen vrijwel onbekend. Hij dankt er wél zijn internationale bekendheid aan. Hij behoort volgens Moelker samen met Janowitz en Aron tot de grote drie van deze subdiscipline en heeft ook buiten onze grenzen onderzoekers met zijn interpretaties en hypotheses geïnspireerd. Ook op dit terrein is rationalisering een centraal thema, zoals al blijkt uit zijn proef- 
schrift van 1956 waarin de hervorming van de organisatie en training van het Staatse leger onder prins Maurits grote aandacht krijgt en vergeleken wordt met de rationalisering van de industriële organisatie enkele eeuwen later.

Volgens Moelker blijft ook dit deel van zijn oeuvre relevant voor sociologen van vandaag de dag, omdat Van Doorn vaak als eerste binnen Nederland thema's en werkhypotheses aan de orde stelde waarop nu nog steeds wordt voortgebouwd. Van Doorns profetische voorspelling van het 'einde van de massalegers' is een thema dat als onderzoeksveld nog steeds relevant is, omdat nog veel landen zich in een overgangsfase bevinden. Anno 2010 zal Zweden zijn dienstplicht opschorten en zal daardoor dezelfde problemen (bijvoorbeeld ten aanzien van werving en rekrutering) moeten oplossen als Nederland na 1996. Maar zelfs in het meest traditionele dienstplichtland van allen, Zwitserland, wordt de discussie gevoerd en het werk van Van Doorn inspireert nog steeds de Zwitserse militair sociologen die de problematiek bestuderen.

De actualiteit van de discussie over de aard van de krijgsmacht en de wijze waarop die krijgsmacht haar legitimiteit verwerft is ook altijd terug te voeren op Van Doorn. In de Verenigde Staten werd deze discussie allereerst door Janowitz en Huntington opgestart, maar ook in de huidige literatuur komt altijd diezelfde vraag terug: 'Hoe uniek mag de krijgsmacht zijn?'. Voor Nederland was Van Doorn de persoon die deze vraag aan zijn publiek voorhield, waarbij hij vaak gebruikmaakte van de term 'hermilitarisering', omdat het volgens hem helemaal niet zo verkeerd is dat de krijgsmacht afwijkend is van de burgersamenleving. Het hanteren van geweld en het bijdragen aan veiligheid is immers ook een heel ander soort maatschappelijke functie dan de productie van consumptiegoederen.

Ook het 'Indische' werk, zoals door Van der Meulen besproken, blijft relevant voor militairen, aangezien 'normvervaging' en de 'ontsporing van geweld' ook risico's vormen voor de inzet van militairen in bijvoorbeeld Afghanistan. Van Doorn verklaarde zich ook tegenstander van de hearts and minds campagnes in Uruzgan, omdat hij eenzelfde afloop vreesde als tijdens de politionele acties. Daarover kan men van mening verschillen. Het verschil tussen beide campagnes is dat de acties in Indonesië betrekking hadden op een dekolonisatieoorlog en dat de operaties in Uruzgan toch vooral stabilisatie- en wederopbouwoperaties zijn. Nederland heeft in tegenstelling tot in Nederlands-Indië geen enkele ambitie om te blijven na 2010 en zou daarom ook in de ogen van de lokale bevolking een geloofwaardige rol kunnen spelen. Het gaat er hier niet zozeer om of Van Doorn gelijk heeft, maar wel dat Van Doorns opvattingen ook hier tot een uiterst actuele vergelijking prikkelen. 


\section{De diagnose van actuele sociaal-politieke ontwikkelingen}

Van Doorn heeft zich in zijn lange carrière steeds over actuele ontwikkelingen uitgelaten en er zijn sociologische licht over laten schijnen. Maar sinds zijn afscheid als hoogleraar is hij zich daar meer op gaan toeleggen en heeft hij daarvoor een vorm gevonden waarmee hij een veel groter publiek kon bereiken dan alleen zijn vakgenoten. Hij ontwikkelde zich tot publiek socioloog, zoals zowel Van der Veen als Pels met een term ontleend aan de Amerikaanse socioloog Burawoy opmerken. Veel sociologen halen vaak hun schouders op bij die stroom van commentaren en bespiegelingen over actuele verschijnselen van de 'stukjesschrijver' die Van Doorn volgens hen geworden was: wat moeten we ermee? Ten onrechte, menen wij. Want in die stukken komt een duidelijk sociologische diagnose naar voren van de recente veranderingen op het sociale en politieke toneel van de Nederlandse samenleving, waar sociologen die zich serieus met de ontwikkeling van onze samenleving bezig willen houden niet omheen kunnen en die vraagt om discussie en verder onderzoek.

Die visie is terug te vinden in het slothoofdstuk dat Van Doorn voor de bundel Nederlandse democratie heeft geschreven en dat we wel zo ongeveer als zijn zwanenzang mogen beschouwen: 'Herfsttij der democratie. Over de huidige malaise in de Nederlands politiek'. Daarin komt een aantal lijnen samen uit zijn latere publicaties en commentaren: de veranderingen in het politieke system, het integratiedebat, de opkomst van het populisme en niet te vergeten: de oprukkende individualisering. Dat laatste proces speelt zelfs een sleutelrol. Zo wordt het verantwoordelijk gesteld voor de uitholling van de partijendemocratie, omdat het de band tussen politici en hun achterban doet vergruizen. De sociaal-democratie kampt daarbij met het oprukkende consumentisme, de christen-democratie met deconfessionalisering en de opkomst van het individucentrische spiritualisme. De partijendemocratie maakt plaats voor een toeschouwersdemocratie ('Roept u maar!'), de politieke fragmentatie neemt toe, het gezag van opinieleiders wordt als gevolg van de opmars van internet steeds meer onderuitgehaald.

Het voornaamste gevolg is dat 'de capaciteit van onze democratische partijen om urgente maatschappelijke vraagstukken ideologisch te benoemen en organisatorisch te lijf te gaan sinds enkele decennia meer en meer verzwakt (is)' (Van Doorn 2009: 480). Dat wreekt zich met name in het onvermogen om een oplossing te vinden voor het minderhedenvraagstuk, of (in de veelzeggende woorden van Van Doorn) 'voor wat al tientallen jaren de belangrijkste uitdaging in onze politiek is: de noodzakelijke emancipatie tot medeburgers van een grote nieuwe minderheid' (idem: 488). Dit vacuüm wordt gevuld door het populisme dat de directe band tussen kiezers en gekozenen, volgelingen en leiders zegt te 
willen herstellen en met het falen van de bestaande partijen goede sier kan maken. En passant constateert Van Doorn ook de opkomst van een nieuwe machtsstructuur, een 'politiek-publicitair complex' dat berust op allianties tussen een aantal journalisten en columnisten enerzijds en sommige politici en politieke activisten anderzijds (idem: 513), waarin de populistische leiders de show kunnen stelen. Van Doorn blijkt zich ervan bewust dat er een soort tegenbeweging tegen het 'fundamentalistische individualisme' op gang komt, maar hij vreest dat dit zal uitlopen op een vorm van 'staatspaternalisme' (iets wat trouwens ook heel goed past bij het populisme met zijn nadruk op de almacht van de leiders).

Dit is een tamelijk uitzichtloze diagnose. De politieke veranderingen van de laatste decennia worden verbonden met het steeds verder oprukkende individualiseringsproces en krijgen daardoor een hoog onvermijdelijkheidsgehalte. Die indruk wordt nog bevestigd door de afwezigheid (in elk geval in het genoemde hoofdstuk) van krachten die de ontwikkeling een andere kant op zouden kunnen sturen en het ontbreken van voorstellen om het tij te keren. Het is daarom een diagnose die sociologen zou moeten prikkelen Van Doorns interpretatie kritisch onder de loep te nemen en door middel van onderzoek te toetsen. Van Doorns opvattingen over oorzaken en gevolgen van individualisering vormen daarbij een voor de hand liggend aanknopingspunt.

In deze bundel wordt de handschoen opgenomen door twee sociologen met een heel uiteenlopende achtergrond, Ultee en Pels. Ultee komt met een eigen verklaring van de opkomst van het populisme, waarin verschillende elementen uit Van Doorns verklaring te herkennen zijn, maar die toch minder zwaar leunt op het individualiseringsproces. Hij ziet de opkomst van het populisme vooral als een nieuwe manifestatie van charismatisch gezag binnen een politieke context waarin ten gevolge van de sociale stijging en het functieverlies van de kerken links en rechts van de bestaande partijen ruimte ontstaat voor nieuwe partijen die het in eerste instantie moeten hebben van charismatische leiders. De 'eigen logica' van de media die ten gevolge van wedijver om de kijkersgunst politieke standpunten versimpelen en politieke kwesties personaliseren versterkt dit proces. Hij komt wel tot een voorstel om het tij te keren, waarbij hij gebruikmaakt van theoretische inzichten over de productie van collectieve goederen. De realiteitswaarde van dit voorstel (de opdeling van de Tweede Kamer in vier Kamers die zich elk met besluitvorming over specifieke collectieve goederen bezighouden) laten we hier in het midden, het gaat ons om het voorbeeld dat - vanuit een ander sociologisch perspectief dan dat van Van Doorn - nagedacht kan worden over manieren om het 'Herfsttij der democratie' te laten verkeren.

Ook Pels is van mening dat Van Doorn door individualisering aan te wijzen als de bron van alle maatschappelijke en politieke malaise 
de deur voor een nadere analyse van deze ontwikkelingen dichtdoet. Ondanks zijn scherpe en scherpzinnige kritiek op het fortuynisme (iets waar andere sociologen zich nauwelijks aan gewaagd hebben) heeft hij volgens Pels de betekenis van de populistische revolte onderschat. Van Doorn zag helder dat de opkomst van het populisme verbonden is met het doordringen van individualisme en consumentisme in de politiek. Maar het bleef bij een 'lucide, maar pessimistische cultuurkritiek', omdat hij afzag van een verdere sociologische analyse van het individualiseringsverschijnsel en geen oog had voor de paradox van het 'geïnstitutionaliseerde individualisme' waarbij de nadruk op het eigene en authentieke uitgroeit tot een nieuwe vorm van dwingend collectief denken. Ook Pels' boodschap voor sociologen die zich met de diagnose van onze tijd willen bezighouden is dus dat zij niet halt moeten houden bij het proces van individualisering en daarmee het denken over alternatieven opgeven.

\section{Conclusie}

Van Doorn heeft, ondanks alle kritiek die er op onderdelen van zijn werk mogelijk is, een veelzijdige sociologische erfenis achtergelaten. Het programma dat hij in het begin van de jaren vijftig van de vorige eeuw formuleerde, de ontwikkeling van een wetenschappelijke sociologie waarin systematisch empirisch onderzoek en sociologische theorievorming elkaar wederzijds bevruchten, is nog steeds onverminderd relevant. Met zijn sociologische visie op modernisering waarin de januskop van het rationaliseringsproces en de voortschrijdende individualisering een centrale plaats innemen, staat hij midden in de actuele discussie over de al dan niet postmoderne samenleving. Op verschillende deelgebieden is zijn werk nog steeds een bron van inspiratie. En bovendien laat hij ons een scherpe, zij het sombere diagnose na van de huidige sociale en politieke veranderingen in de Nederlandse samenleving.

Bij dat alles bleef hij vooral een socioloog die, zoals Van der Veen zegt, niet primair gericht was op het vooruitbrengen van het sociologische ambacht, maar op de vergroting van het sociologisch inzicht in maatschappelijke ontwikkelingen. Dat deed hij vooral door het aanbieden van wat wij hierboven nieuwe interpretaties genoemd hebben. Het zijn interpretaties die dikwijls tegenspraak uitlokken (maar tegenspraak brengt ons verder) en die in elk geval vragen om verdere uitwerking en systematische toetsing. Uitdagingen genoeg dus voor nieuwe generaties sociologen. Zij worden door hem (zie het motto van dit stuk) opgeroepen om naast hun ambachtelijke knowhow toch vooral hun sociological imagination verder te ontwikkelen. 


\section{Geraadpleegde literatuur}

Doorn, J.A.A. van (1994), De laatste eeuw van Indië. Ontwikkeling en ondergang van een koloniaal project, Amsterdam: Bert Bakker.

Doorn, J.A.A. van (2000), 'Sociale wetenschappen en de weerbarstige werkelijkheid', in: P.B. Lehning (red.), De beleidsagenda 200o. Strijdpunten op het breukvlak van twee eeuwen, Bussum: Coutinho, p. 24-41.

Doorn, J.A.A. van (2009), Nederlandse democratie. Historische en sociologische waarnemingen, Amsterdam: Mets \& Schilt.

Doorn, J.A.A. van en C.J. Lammers (1959), Moderne sociologie. Systematiek en analyse, Utrecht: Het Spectrum. 



\section{Over de auteurs}

Leonard Blussé (1946) is hoogleraar geschiedenis van de Europees-Aziatische betrekkingen, Universiteit Leiden, en buitengewoon hoogleraar aan de Nanyang Research Academy, Xiamen University. Zijn onderzoek betreft Europees-Aziatische betrekkingen in Oost- en Zuidoost-Azië in de vroegmoderne tijd. Recentelijk publiceerde hij Visible Cities. Canton, Nagasaki and Batavia and the Coming of the Americans (Cambridge: Harvard University Press, 2008).

Joop Ellemers (1930) studeerde sociologie aan de Universiteit van Amsterdam. Hij behoorde met J.A.A. van Doorn en anderen tot de oprichters van de Sociologische gids, hij was van 1967 tot en met 1995 hoogleraar Empirische Sociologie aan de Rijksuniversiteit Groningen en van 1970 tot en met 1995 buitengewoon hoogleraar aan de Vrije Universiteit Brussel.

Jacques van Hoof (1942) is emeritus hoogleraar sociologie (Universiteit Leiden) en arbeidsmanagement en omgeving (Radbouduniversiteit Nijmegen). Hij is voorzitter van de NSV en redactielid en medeoprichter van het Tijdschrift voor Arbeidsvraagstukken. Hij publiceerde recentelijk artikelen over 40 jaar veranderingen in het arbeidsbestel en over ontwikkelingen in het onderzoek naar arbeids- en organisatievraagstukken. Ook is hij co-redacteur en co-auteur van een inleiding in de sociologie: Sociologie en de moderne samenleving (1996).

Dick Houtman (1963) is hoogleraar cultuursociologie aan de Erasmus Universiteit. Hij publiceerde de afgelopen vijf jaar vooral over de culturalisering van de politiek en de spiritualisering en revitalisering van religie, onder andere in Social Forces, Journal for the Scientific Study of Religion, British Journal of Criminology, Politics and Society, European Journal of Political 
Research, Journal of European Social Policy en American Behavioral Scientist. Zijn meest recente boeken zijn Farewell to the Leftist Working Class (2008, met Peter Achterberg en Anton Derks) en Religions of Modernity (2010, redactie met Stef Aupers).

Cor Lammers (1928-2009) was emeritus hoogleraar organisatiesociologie aan de Universiteit Leiden en hield zich recentelijk vooral bezig met de studie van de organisatie van bezettingen in verleden en heden. Samen met J.A.A. van Doorn schreef hij het in 1959 verschenen boek Moderne sociologie, dat jarenlang gold als standaardwerk. De verschillende edities van zijn boek Organisaties vergelijkenderwijs vormden voor menigeen het referentiekader binnen de organisatiesociologie.

Peter Mascini (1968) is universitair docent aan de vakgroep sociologie van de Erasmus Universiteit. Hij verricht vooral onderzoek naar de legitimering, uitvoering en handhaving van beleid. Hierover publiceerde hij bijvoorbeeld in Regulation and Governance, Law and Policy, British Journal of Criminology, International Migration Review en Sociologie.

Jan van der Meulen (1951) is universitair hoofddocent aan de Faculteit Militaire Wetenschappen van de Nederlandse Defensie Academie (NLDA) en bijzonder hoogleraar militair-maatschappelijke studies aan het Departement Politieke Wetenschap van de Universiteit Leiden. In zijn onderzoek en publicaties draait het om ontwikkelingen in het publieke draagvlak voor riskante militaire missies.

René Moelker (1960) is als universitair hoofddocent krijgsmacht en omgeving verbonden aan de NLDA. Zijn werk in de militaire sociologie omvat de sociologie van militaire gezinnen, militaire technologie, het militaire beroep en de media. Over het militaire beroep publiceerde hij in British Journal of Sociology. Over de samenwerking tussen Duitse en Nederlandse militairen publiceerde hij in het tijdschrift Armed Forces and Society. Samen met Stephen Mennell redigeerde hij een postuum verschenen boek van Norbert Elias, The Genesis of the Naval Profession (University College Dublin Press, 2007).

Dick Pels (1948) werd, na een bijzonder hoogleraarschap in de sociale kennistheorie aan de universiteit van Groningen, in 1998 gewoon hoogleraar in de sociologie en de cultural studies aan Brunel University in Londen. In 2002 keerde hij terug naar Nederland en verliet hij de universiteit om voor zichzelf te beginnen als freelancepublicist. Zijn huidige belangstelling en onderzoek richten zich op de uitdagingen van het populisme, de opkomst van de celebritycultuur, de rol van religie in een 
seculariserende cultuur, de toekomst van Europa en het ideaal van de meritocratie.

Sjo Soeters (1954) is als hoogleraar management en organisatievraagstukken verbonden aan de Faculteit Militaire Wetenschappen van de NLDA. Daarnaast is hij buitengewoon hoogleraar organisatiesociologie aan de Faculteit Sociale Wetenschappen van de Universiteit van Tilburg. Zijn vele publicaties betreffen onder andere de interculturele samenwerking tussen militairen van verschillende nationaliteiten.

Wout Ultee (1946) verdedigde in 1970 in Utrecht een proefschrift over stagnatie in de sociologie en is sinds 1987 hoogleraar in Nijmegen. Hij publiceerde in de European Sociological Review over dubbele werkloosheid in (huwelijks)paren, de American Sociological Review over opleidingshomogamie in 65 landen, en de American Journal of Sociology over de kans op zelfdoding van Nederlanders afhankelijk van hun godsdienst en de godsdienstige samenstelling van hun woonplaats.

Romke van der Veen (1958) is hoogleraar sociologie van arbeid en organisatie aan de Erasmus Universiteit. Zijn onderzoek en publicaties richten zich op de ontwikkeling en vooral de uitvoering van beleid in de context van de nationale verzorgingsstaat.

Casper Vroom (1942) was hoogleraar organisatiesociologie aan de Koninklijke Militaire Academie en Comparative Management aan de Universiteit Maastricht. Daarnaast doet hij nog steeds bij tijd en wijle organisatieadvieswerk. Op het moment is hij bezig met een studie naar het stadsbestuur van Córdoba ten tijde van het westers kalifaat (1ode eeuw na Christus). 



\section{Register}

Abrahamsson, Bengt 107

Achterberg, Peter 161, 165

Albert, Hans 55

Alexander, Jeffrey $\quad$ 155, 163

Allison, Paul 53

Aron, Raymond 104

Arts, Wil 48

Aupers, Stef 168

Baar, Dirk-Jan van 90

Baudet, Han 71-72

Bauman, Zygmunt 185

Becker, Howard 166

Beck, Ulrich 185

Beijer, Henk 28

Bemmel, Noël van 53

Berlin, Isaiah 33

Beus, Jos de 22, 56, 63, 90, 96, 139, 184

Bienemann, Jos 53

Black, Donald 155, 162

Blom, Hans 51

Blussé, Leonard 180, 182

Boeke, Julius 71

Bon, Gustave le 38

Born, Hans 116

Bosch, Jolanda 110, 114
Boudon, Raymond 61

Bouman, Pieter Jan 27, 158

Bourdieu, Pierre 88

Bovenkerk, Frank 35

Braak, Menno ter 96

Breman, Jan 22, 69-70

Brentjens Harry, 109

Brink, Gabriël van den 87

Burawoy, Michael 88-91, 188

Burggraaf, Willem 116

Burk, James 104

Buzzati, Dino 145

Caforio, Giuseppe 114

Campo, Joep da 71

Carreiras, Helena 110

Castells, Manuel 61-62

Cate, Arthur ten 135-137

Cliteur, Paul 93

Creveld, Martin van 110

Crippen, Timothy 155, 162

Croes, Marnix 51-52

Dahrendorf, Ralf 23

Dalrymple, Theodore 93

Dawidowicz, Lucy 60

Deleuze, Gilles 91

Doel, Hans van den 49-50, 63, 177 
Doel, Wim van den 71

Doorn, Jacques van passim

Durkheim, Emile 33-34, 160, 167

198 Duyvendak, Jan Willem 163

Eisinga, Rob 164

Elchardus, Mark 165

Elias, Norbert 91, 106-107, 118

Ellemers, Joop 170, 182-183

Ellian, Afshin 93

Engbersen, Godfried 87

Ephimenco, Sylvain 93

Etzioni, Amitai 29

Falter, Jürgen 59

Fasseur, Cees 71

Flap, Henk 48, 51

Fortuyn, Pim 11, 39, 87, 90-91, 93, 95

Foucault, Michel 91

Freud, Sigmund 38

Giddens, Anthony 88, 185

Goffman, Erving 29, 115-116

Gogh, Theo van 93

Gombrich, Ernst 61

Goor, Jur van 71

Goudsblom, Joop 27

Gouldner, Alvin 155-166

Gramsci, Antonio 88

Groenman, Sjoerd 27

Groen, Petra 71, 134

Habermas, Jürgen 159

Haltiner, Karl 113-114

Haveman, Jan 34-35, 184

Heek, Frederik van 27-28, 55

Heijden, Cor van der 50

Hendrix, Wim 10, 22, 27-28, 69-71, 102, 104, 130-134, 146-147, 149

Hessen, Jan van 116

Hobbes, Thomas 33

Hofstee, Evert Willem 27
Hollander, Arie den 27

Holman, Theodor 93

Homans, George 103

Hoof, Jacques van 48

Horowitz, Irving 155, 162

Houtman, Dick 12, 161-168, 180181

Howard, Michael 149

Huizinga, Johan 48-49, 117

Inglehart, Ronald 164

Jager, Hugo de 18, 28

Janowitz, Morris 20, 103-104, 106$107,139-140,186-187$

Jansen, Hans 93

Jansen, Henk 40

Jong, Lou de 51

Jong, Sjoerd de 90

Kinneging, Andreas 93

Kitsuse, John 166

Klinkert, Willem 107

Kohn, Melvin 164

Korpi, Walter 53

Kruijer, Gé 17

Kruijt, Jakob 27, 54-55

Kuhn, Thomas 178

Kuitenbrouwer, Maarten 71

Kümmel, Gerhard 117

Laeyendecker, Leo 48

Lammers, Cor 13, 19, 27, 34, 47, 71-72, 79, 116, 119, 155, 183

Lazarsfeld, Paul 79

Lemert, Charles 155, 162

Lenski, Gerhard 48

Lepenies, Wolf 162

Leune, Han 80-81

Lipset, Martin 61, 164

List, Gerry van der 90, 93, 158

Litjens, Harry 158

Livestro, Joshua 93 
Locher-Scholten, Elsbeth 71

Lopreato, Joseph 155, 162

Luijkx, Ruud 51

Lyotard, Jean-Francois $\quad$ 159, 168

Manigart, Philippe 113

Mannheim, Karl 33, 91

Mans, Jan 139

Marx, Karl 28, 33, 167

Mascini, Peter 161

McNeill, William 55

Meijer, Remco 60

Merton, Robert 19, 34, 79, 103, 157, 160-161

Meulen, Jan van der 11-12, 102, 113,187

Michels, Robert 29, 33, 55

Mierlo, Hans van 95

Mills, Wright $88,155,157,160-$ 161, 166

Moelker, René 11, 110, 114, 116$117,119,183,186-187$

Mok, Albert 18, 28

Moskos, Charles 107, 109, 114

Need, Ariana 57

Nietzsche, Friedrich 28, 33

Nijhoff, Piet 34

Nijhof, Gerhard 164, 167

Oakes, Guy 166

Olson, Mancur 50,63

Oosterhuis, Gertjan 107

Palme, Joakim 53

Pam, Max 93

Parsons, Talcott $33-34,79$

Pels, Dick 34, 91, 173, 180, 188-190

Peper, Bram 90

Philipse, Herman 93

Pick, Daniel 55

Popper, Karl 47-48, 54, 61, 63, 170
Rawls, John 159

Richardson, Rudy 110, 114, 116

Rijk, Martijn de 23, 47, 52, 62

Rooy, Piet de 22, 96, 139, 184

Roszak, Theodore 166

Rutenfrans, Chris 93

Saïd, Edward 91

Scagliola, Stef 130

Schaberg, Johan 145

Schaper, Bertus 70

Scheepers, Peer 164

Schijf, Bert 133-134

Schillebeeckx, Edward 159

Schinkel, Willem 87, 91

Schuyt, Kees 27, 82, 101, 170

Seidman, Steven 155, 162

Shils, Edward 103

Simmel, Georg 33, 91

Singer, Peter 115

Siongers, Jessy 165

Slomczynski, Kazimierz 164

Sniderman, Paul 165

Soeters, Sjo 119

Sorel, Georges 38, 91

Spector, Malcolm 166

Spengler, Oswald 28, 33

Spruyt, Bart Jan 90, 93-94

Steenhuis, Henk 93

Stouffer, Samuel 103

Swaan, Bram de 27, 50, 53

Szvircsev Tresch, Tibor 114

Tammes, Peter 51-52

Thurlings, Jan 48

Tocqueville, Alexis de 185

Tonkens, Evelien 87

Toulmin, Stephen 159

Tromp, Bart 35, 55, 6o, 95

Tubergen, Frank van 156

Tulder, Johannes van 55

Turner, Jonathan 155, 162

Turpijn, Chris 109 
Ultee, Wout $10,27,48,51-52,54$, Waal, Jeroen van der 161 57, 69-70, 180, 182-183, 189 Weber, Max 33-34, 49, 55, 61-62, 78, $81,126,156,162,167-168,185$

200

Veen, Romke van der 37, 40, 169, 180, 184-186, 188, 190

Wesseling, Henk 70-71

Wielek, Heinz 60

Verbrugge, Ad 93

Wilders, Geert 39, 93, 96

Vercruijsse, Emile 55

Winter, Leon de 93

Verdonk, Rita 96

Wippler, Reinhard 55

Vink, Jaffe 93

Wittek, Rafael 161

Vroom, Cas 11

Vroom, Casper 116

Zijderveld, Anton 27, 166, 170 